\title{
WAS MALAKA EMPORIUM VÓÓR 1400 A. D., GENAAMD MALAJOER? \\ EN WAAR LAG WOERAWARI, MĀ-HASIN, LANGKA, BATOESAWAR?
}

(Met terreinschetsen van Djambi, oud-Singhapoera, en de Djohor-tivier)

DOOR G. P. ROUFFAER.

Eerste Gedeelte:

Malajoer is niet Malaka, doch Djambi.

$($ Woerawari $=$ Langka $=$ Galoeh $=$ Djohor $)$.

(Mahasin $=$ Hasin $=$ Toemasik $=$ Singhapoera $).$

Tegelijkertijd werden hier in Nederland in voorjaar 1919 ontvangen twee studies van Fransche geleerden, die gewichtige onthullingen brachten over de oude geschiedenis van Sumatra en het schiereiland Malaka; speciaal over het rijk Palembang en over de stad Malaka. Het eene opstel is van Dr. G. CoEDÈs, conservator van de Nationale Bibliotheek te Bangkok, "Le royaume de Çrīvijaya», in het Bulletin de l'Ecole française d'Extrême-Orient, XVIII (1918), $\mathrm{n}^{\circ}$ 6; het andere van den Arabist en Madagascarkenner G. Ferrand, in het Journal Asiatique van 1918, dl. I-II, getiteld "Malaka, le Malāyu et Malāyur».

De studie van den heer Coedès onthult ons op onweerlegbare wijze: dat het "koninkrijk van Çrīwidjaja», de kadatuan Çriwijaya, genoemd in de oud-Maleische inscriptie van Kota Kapoer (West-Bangka) uit 608 Çaka (686 A. D.), vereenzelvigd moet worden met het rijk van Palembang, dat op de zgn. groote Tanjore-inscriptie van $1030 \mathrm{~A}$. D. als het bloeiende "Crīvijay a m » nog wordt genoemd; het San-bo-tsai (of San-fo-ts'i) uit de Annalen der $2^{\mathrm{e}}$ Soeng-dynastie tusschen 905 en 1178 (GroeneDl. 77. 
veldt's Notes, $1^{\text {e }}$ ed. 1876 , p. 62-67), dat daar in den aanhef wordt gememoreerd als heerschend "over fifteen different countries* (p. '62); het rijk ook van den Mahārādja van $\mathrm{Z} \bar{a}$ badj $=$ Sěrboza (Çrïbodja) der Arab. bronnen tusschen 846 en 1321; het $\mathrm{S}$ embodja of $\mathrm{Sambodja}$ der ongedateerde Jav. overlevering (15 eeuw); het $\mathrm{Pau}-\mathrm{lin}-\mathrm{pang}$ van 1374 (Annalen der Ming-dynastie; Groeneveldt p. 69).

Kortom: het was het machtige rijk van den Mahārādja van Zuid-Sumatra, met hoofdstad Palembang, tusschen ca. 650 en 1400 A. D.; waarvan het alleroudste vermelden tot nog toe gevonden is in het Shih-li-fuh-shi of Fo-shi (Çrī-bhodja of Bhodja; waarin - blijkens het hoogst verrassend argument door den heer Coedès, p. 24, aan de epigraphie van Tjampa ontleend - Chin. fo-shi=Skr. vijaya is) uit 670 A. D., in de Annalen der T'ang-dynastie. Dit laatste, het eerst door BEAL (1883), dan door Groeneveldt opgehelderd Chin. gegeven (Supplementary Jottings, T'oung Pao, VII, 1896, p. 116-121), sluit zóó schitterend aan bij het 4 maal op de (in 1892 ontdekte) inscriptie van Kota Kapoer voorkomend Çrīwidjaja, en bij de prachtige vondsten van den heer Coedès uit 1918, dat de circa 800-jarige geschiedenis van Palembang als opperrijk in Zuid-Sumatra, plotseling is komen te rusten op de Bangka-inscriptie van 686 A. D., getranscribeerd het eerst door Dr. Brandes, voor anderen het eerst vertaald en toegankelijk gemaakt door Prof. Kern in 1913. ${ }^{1}$ Het éénige onderdeel in al deze gegevens dat nog raadselachtig blijft, is - verg. Coedès' noot 5 op p. 24 - het Sa n in de Chin. transcriptie "San-bo-tsai», sedert ca. 900 A. D. De oplossing zal wellicht gevonden worden via het honorifieke Oudjav. sang, ook al wordt dit alléén voor persoonsnamen en persoonsaanduidingen gebezigd.

Even verrassend als de studie van den heer CoEDÈs, is die van den heer FERRAND.

Kort samengevat, is de kern van Ferrand's vervolg-artikel hier verderop aangehaald naar de oorspronkelijke pagineering in het Journal Asiatique, niet naar die van den totalen overdruk,

1 De herdruk, met facsimile, in Prof. Kern's Verspreide Geschriften, dl. VII (1917), p. 205-214, stond aan Coedès te Bangkok blijkbaar niet ter beschikking. Het jaartal van Groeneveldt's Notes, $1^{\mathrm{e}}$ editie, is 1876 , niet 1880 (Coedès, p. 7); dit laatste was het jaar waarin dl. XXXIX der Verhand. Batav. Gen. compleet kwam, in hetwelk Groeneveldt's Notes het $1^{\bullet}$ stuk was geweest van de totale 5. 
waarin p. 5-98 en $99-202$ resp. zijn = J. A. 1918, I, p. 391484 ; en II, p. 51-15t - het volgende: or bestonden tusschen ca. 800 en 1400 trvee Malajoe's; één, het Malajo e- of DjambiMinangkabau-gebied op Sumatra; en een tweede, de stad Malaka op het schiereiland van dien naam, welke stad nà ca. 1400 heetende Malaka, vóór 1400 heette Malajoer (Malāyur), bij corruptie of verwisseling - doch eigenlijk onzuiver - óók wel Malajoe (Malāyu).

Voor het eerste, het Sumatraansche, Mala joe-proper, oorspronkelijk sedert ca. 650 A. D. aan Djambi (stad en landschap) toekomend - verg. Notulen Bat. Gen. 1909, p. 116-117 ${ }^{1}$ zegt. Ferrand: "On vient de voir que, pour les raisons que j'ai dites, je partage entièrement l'opinion exprimée pirr M. Rouffaer, en ce qui concerne l'identification de Mo-lo-yu à Djambi» (I, p. 481); daarna, bij uitbreiding, werd die naam. overgedragen op het bovenstroom-gebied ook van de rivier van Djambi, de boven-Batang Hari, dus op het gebied Dharmāçraya-Minangkabau der malaïseerende Sanskrit-inscripties van 1208 en 1269 Çaka (zie resp. Dr. Krom over de eerste in Versl. en Meded. Kon. Akad. afd. Lett., 5, II, 1916; Prof. Kern over de tweede in Tijdschr. Bat. Gen. XLIX, 1907, herdrukt met facsimile, in zijn Verspr. Geschr. VII, 1917). Zoo spreekt dan ook Ferrand verderop voor het jaar 1275 A. D., van dit «Malāyu-Minankabaw» (II, p. 105), en van latere emigranten die naar het grondgebied van Malaka "venaient du Minańkabaw, c'est-à-dire du Malāyu de Sumatra (p. 111).

Maar voor het tweede, het Malak'sche, Malajoe r-proper (volgens Ferrand), de stad Malaka van vóór 1400 A. D., komt Ferrand met de meest verrassende nieuwe argumenten. Marco Polo's befaamd "Malaiur» van 1292, door dezen beschreven nà $" \mathrm{Pentam}$ ( $=$ het toen onbewoonde eiland Bintan ${ }^{2}$, en vóór

1 Voor de drukfouten in mijn referaten aldaar, ben ik niet aansprakelijk; ik was toen op Koepang (Timor), en de correctie der drukproeven van mijn hs. was te Batavia in handen van den ten deze ongeoefenden Secretaris Bat. Genootschap.

2 Niet Bintang, zooals Ferrand doorloopend meent (I, p. 417 en later). Het eiland heet naar den kustboom bintan, Cerbera Odollam Gaertn., een A pocynee; zie toch De Clereq \& Greshoff, Nieuw Plantkundig Wrdb. voor N.-I., 1909, No. 720. - Zéér verwonderlijk blijft, dat de Nāgarakrětāgama (1365 A. D.) niet het eiland Bintan (alias Riouw) noemt, maar wèl, waarschijnlijk ten minste, het kleinere, ten W. van Bintan gelegen Batam (in Zang 13: Batan); en 
¿Ferlec» = het toen Moh. koninkrijk Perrlak, is volgens hem, dat oudere Malaka. Waar Polo - naar de vertaling door Yule van den oud-Franschen tekst - schreef:

"And when you have gone these 60 miles [n. l. na Bintan (= Riouw) achter zich gelaten te hebben], and again about 30 more, you come to an Island which forms a Kingdom, and is called Malaiur. The people have a King of their own, and a peculiar language. The city is a fine and noble one, and there is great trade carried on there. All kinds of spicery are to be found there, and all other necessaries of life.» (The Book of Ser Marco Polo, $3^{\text {rd }}$ ed. Yule-Cordier, 1903, II, p. 280).

- daar interpreteert Ferrand niet, zoo als men tot nog toe steeds deed, dat "Island» en die "city» resp. als Zuid-Sumatra, en de stad Palembang; maar als : het Maleische Schiereiland, en de stad Malaka. Door verder te steunen op een Portugeesch-Indischen geschiedschrijver, dien hij geloofwaardig acht, GASPAR CORREA, welke in ca. 1561 te Goa in zijn handschrift neerschreef, dat Malaka (als stad) meer dan 700 jaar gelegen had waar het lag toen de Portugeezen er heengingen (het eerst onder Sequeira in 1509; dan definitief onder Albuquerque in 1511), komt Ferrand tot de opzienbare gevolgtrekking: dat Malaka als stad bestaan zou hebben sedert \pm 800 A. D., en dan onder dien ouderen naam dien alléén Marco Polo in eind 1291 of begin 1292 heeft als oudste Westersche reiziger: Malaiur.

In Ferrand's eigen woorden: "La ville ou l'état de MalāyuMalāyur-Malaka, organisé et prospère, emporium achalandé, en relation avec la cour de Chine vers la fin du XIII ${ }^{\mathrm{e}}$ siècle [lees: $\mathrm{XIV}^{\mathrm{e}}$ siècle! ${ }^{1}$ of juister: dès le commencement du XVe siècle; het oudste bericht over "Moa-la-ka» is dat van 1403 in de Annalen 'der Ming-dynastie, Groeneveldt's Notes, 1876, p. 129], ne pouvait pas être alors de fondation récente, ni relativement proche.... Par éliminations successives, on en arrive à la date de Gaspar Correa: le VIII ${ }^{\text {e }}$ siècle, qui paraît ainsi la seule pos-

dat, waar Bintan een zóó groote rol speelt in de historische overlevering der Maleiers. Zie toch Dr. Schrieke, Het boek van Bonang, 1916, p. 12 noot 2, en p. 22 noot 1 ; alsmede hierachter passim.

1 Het is toch niet toelaatbaar, dat Ferrand hierbij mag gedacht hebben aan het onzekere Chin. Ma-li-yu-eul uit 1295 A. D., dat straks (blz. 10-11) nader ter sprake komt. Dit zou èn een petitio principii zijn, èn een fout. 
sible. Cette conclusion bouleverse toutes les données admises, non seulement sur la date de la fondation de Malaka, mais sur celle de la ou des migrations malaises à la péninsule. On admet généralement qu'elles ont eu lieu à relativement basse époque et- que ces immigrants venaient du Minañkabaw, c'est-à-dire du Malāyu de Sumatra...; mais il est non moins possible que, comme on l'indiquait à Marsden, des Malāyu de la péninsule aient émigré à Sumatra où ils auraient fondé le futur Empire de Minañkabaw.» (II, p. 111-112).

Inderdaad, - bij eerste lezing van deze stoute nieuwe opvattingen omtrent het bestaan der stad Malaka in 800-1400, onder den naam Malajoer, alias Malajoe, voelt men zich "bouleversé».

Maar bij nader kritisch toekijken en herlezen, komt het ongeloof boven. Is het mogelijk dat Marco Polo in 1292 met zijn «Malaiur» heusch Malaka heeft bedoeld? Of dat Fra Odorigo van Pordenone, die in 1323 op Noord-Sumatra (te "Lomori», èn "Summoltra») verbleef, totaal over een oud-Malaka zou zwijgen? Of dat Ibn Batoeta, die in 1345-46 op de heen- en terugreis naar en van ZuidChina, tweemaal vertoefd heeft te Soematra-Samoedra, eveneens totaal gezwegen zou hebben over een emporium van Malajoe(r), dat hij tweemaal voorbij moet hebben gevaren aan den overwal, op het schiereiland Malaka? En (vooral dan toch!): is het mogelijk, dat het lofdicht van Prapantja op Hajam Woeroek, den grooten koning van Madjapahit, uit 1287 Çaka $=1365$ A. D., wèl allerlei aan Oost-Java suzereine staten opsomt op het eiland Malajoe $($ Malayu $)=$ Sumatra, waaronder $\mathrm{N}^{\circ} .1$ Djambi, $\mathrm{N}^{\circ} .2$ Palembang, $\mathrm{N}^{\circ} .4$ Dharmāçraya, $\mathrm{N}^{\circ} .7$ Minangkabau (Ma na ng kabwa), enz., en wèl allerlei ook aan Madjapahit suzereine staten opsomt op het schiereiland Malaka, dat toen in zijn geheel $\mathrm{Pahang}$ heette (gelijk Dr. Krom terecht herkend heeft uit den eigen tekst) ${ }^{1}$, maar.... geen enkelen naam daarbij, die in de verte doet denken aan Malajoer of Malajoe? En is het niet even verwonderlijk, dat de Oudjav. kroniek Pararaton wèl duidelijk spreekt over de Pamalayu, den tocht van 1197-1215 Çaka langs de Batang Hari naar Malayu, d. i. het Djambi-Dharmāçraya-Minangkabau-gebied - dus resp. naar Malajoe-proper en Malajoe-major -

1 Het eerst in Tijdschr. Aardr. Gen. 2, XXXII (1915), p. 217-218. Zie thans de nieuwe ed. Kern-Krom van Prapantja's Nāgarakṛtāgama (1919), tekst p. 50-51, bespreking p. 258-260, met de bijbehoorende kaart. 
door Jav. troepen uit Oost-Java, maar èn niets weet van eenig Malajoe of Malajoer op het schiereiland der Straits Settlements, èn alleen in ca. 1260 Caka $=1338$ A. D. (Ibn Batoeta's tijd bijna!) noemt een vijandig $\mathrm{Haroe}$ (zeg thans: Langkat) en Palembang op Sumatra, alsmede een vijandig Pahang en Toemasik (= Singhapoera) op het Schiereiland (ed. Brandes, 1896 ; tekst p. 18,24 en 28 ; vertaling p. 65,76 en 120)? ${ }^{1}$

Is het op zichzelf niet haast onaannemelijk, dat de naam Malaka, die van 1403 A. D. af door de Chin. berichten absoluut vast staat, vóór 1400 zou geluid hebben: Malajoe(r); terwijl toch de stads- en landsnaam Malajoe sinds ca. 650 leefde op Sumatra, en alleen in niet-Maleische en niet-Javaansche bronnen een Malajoe $+r$ tot nog toe 3 maal gesignaleerd is kunnen worden: $1^{\circ}$. de groote Tanjore-inscriptie van $1030 \mathrm{~A} . \mathrm{D}$., zie Coedès p. 5: Malaiyūr; $2^{\circ}$. Marco Polo in 1292: Malaiur, met name in den Italiaanschen tekst, sinds 1559 in Ramusio's dl. II gedrukt en herdrukt; $3^{\circ}$. de Yüan-che of Annalen der Yüan-dynastie in 1295: Ma-li-yu-eul, zie Ferrand, II, p. 85; om liefst te zwijgen van die verdachte lezing bij Ibn Sa'id en an-Nowairī, twee Arab. schrijvers uit ca. 1260 en 1320: Malāìr, zie Ferrand, II, p. 89-91, waarvoor Ferrand-zelf thans liever een verhaspeld Malājoe wil lezen, dan zooals vroeger in zijn Relations de Voyages, II, 1914, p. 343, 396, een aan te vullen Malājoer; en om liefst heelemaal te veronachtzamen het nog erger in Arab. schrift verloopen Malāb.r bij al-Dimaschkī in ca. 1325, zie Ferrand's Relations, p. 383; of wel de baarblijkelijke kopiisten-fouten in sommige hss. van Marco Polo: Malanir, Malavir, Maliur (zie Yule-Cordier's ed., II, p. 281, noot 3)?

De drie éénige ernstig-gedocumenteerde lezingen van Malajoe $+\mathrm{r}$ zijn derhalve de drie eerstgenoemde. $Z_{\text {ij }}$ mogen dus nader afzonderlijk hier worden bezien; te meer, omdat het allereerste in Ferrand's betoog ontbreekt (door vroeger verschijning).

I. Dank zij het baanbrekende artikel van Dr. CoEDÈs weten we thans, sinds 1918, dat "l'ancien Malaiy ū r (avec) un fort situé sur une haute colline» van de zgn. groote Tanjore-inscriptie uit 1030 A. D., niet gezocht moet worden bij Arcot, in het binnenland beW. Madras, in een tegenwoordig dorp Gudimallur,

1 Zie thans de in Dec. 1920 versehenen $2^{\circ}$ ed. Brandes-Krom, Verh. Bat. Gen. LXII; tekst p. 24-25, 31 en 36; vertaling p. 79, 92 en 141. 
zooals men omnium consensu meende, met Ferrand-zelven als een der overtuigden tot heden (zie o. a. zijn Relations, II, 1914, p. 646 noot 11; arsmede den Index van dat dl. II), maar.... dat het een kuststaat moet zijn geweest ò op Sumatra òf op de Chersonesus der Maleiers! Het staat daar als №. 4 op de lijst der groote zee- en zege-tochten van den Tamil-Chola-vorst Rājendracola I (1012-1042 A. D.), aldus - alles volgens Coedès' interpretaties! -: $\mathrm{N}^{\circ}$. 1. Kèdah (Ka ̣ạa $\mathrm{ram}$ ), rijk aan strijd-olifanten; No. 2. Palembang (Çrīvijay a m), het bloeiende; $\mathrm{N}^{\circ}$. 3. Panei (Paṇnai), aan een rivier (dus: de Panei-Baroemoen-rivier); No. 4. Malaiy ūr, zie boven; Nos. 5-11. diverse zeestaten, meestal op de Chersonesus te zoeken (waaronder ook het nog àltijd twijfelachtige Lěngkasoeka als $\mathrm{N}^{n}$. 6 , en het al bij Ptolemaeus voorkomende Tákôla als $\mathrm{N}^{\circ}$. 10); en ten slotte als $\mathrm{N}^{\circ} .12$, Groot-Atjeh (Lamoeri; Ilāmurideçam) en $\mathrm{N}^{0}$. 13. de Nicobaren (Mānakkavāram; door Yule \& Burnell al in hun Hobson-Jobson van 1886 i. v. "Nicobar Islands» herkend). De inscriptie eindigt dan, door nògmaals Kðdah te vermelden ( $\mathrm{K}$ a ḍ $\bar{a}-$ ram à la force terrible, qui était protégé par la mer voisine»; Coedès p. 5), dus als staat die vooral machtig was te land door zijn strijd-olifanten (Mal. kědah o.a. = olifanten-val).

Had Ferrand dit éérder geweten, dan zou hij er een geducht argument van gemaakt hebben èn voor zijn Malājoer-Malakahypothese, èn voor den door hem aan de hand van GASPAR CORREA naar de $8^{\mathrm{e}}$ eeuw A. D. teruggeschoven ouderdom van dit Maleische emporium. Want in deze Tanjore-inscripties wordt Malaiyūr, zooals men zag, opgesomd bij den overgang van Sumatra op de Chersonesus; dus kan het even goed liggen West als Oost van Straat Malaka. Voorts is Malaka tot heden toe bekend om zijn heuvel aan zee, aan welks $\mathrm{N}$. W. voet de Maleische Vorsten hun astana hadden met een pagar om den heelen voet van den heuvel, waarvan de Portugeezen hun ommuurde stad Malaka maakten met hun hoogopgebouwd fort op de eigen plek der vroegere astana, daarna in 1641 overgegaan op de Hollanders en in 1670 deels nieuw ommuurd; en waar tot heden toe, boven op den heuvel-zelf, de Engelsche Resident van dit deel der Straits Settlements woont, in de schaduw haast der ruïne van de oude Jezuïeten-kerk St. Paul, boven op dien top; een seinpost voor schepen vroeger, en nu.

Had Ferrand dit dus eerder geweten, dan zou hij uit het Tamil- 
gegeven van 1030 A. D. zijn sterkste argument hebben gesmeed, om zijn antiek Malaiyūr-Malāyur-Malaka tot overgaaf te dwingen, ter volstrekte overtuiging van allen!

Straks zal evenwel met $90 \%$ waarschijnlijkheid blijken, dat inderdaad bedoeld moet zijn: de op een hoogen rivieroever gelegen stad Djambi, het antieke Malajoe.

II. Het historisch argument van Ferrand begint inderdaad bij Marco Polo's * Malaiur» uit 1292.

Was dit nu Palembang, of kan het oud-Malaka zijn?

Hierop is niet anders te antwoorden, dan dit: indien wij zeker wisten, dat èn Palembang èn Malaka als emporia bestonden in ca. 1250 A. D., dan zou Polo met zijn "Malaiur» naar $60 \%$ waarschijnlijkheid toch nog hebben bedoeld Palembang, naar slechts $40 \%$ waarschijnlijkheid oud-Malaka. Want, men vergete dit niet: hij gaat niet dóór met het verhaal van zijn reis, nà dat spreken over "Malaiur»; maar hij begint opnieuw met zijn "Pentam», en zegt, onmiddellijk volgend op het boven aangehaalde:

"When you leave the Island of Pentam and sail about 100 miles, you reach the Island of Java the Less [Java Mineure]. For all its name 'tis none so small but that it has a compass of two thousand miles or more.... You see there are upon it eight kingdoms» [volgt de beschrijving van 6 dezer 8 n.l. Ferle $\mathrm{c}=$ Perlak; Bas ma= Pasei (?; of Pasaman??); Sa mara $=$ Samoedra; Dagroi a $\mathrm{n}=$ Chin. Na-kuerh $?=$ Nakur, Nagore $=$ Pedir ; L a mbri $=$ Groot-Atjeh; Fansur $=$ Baroes; en $7-8=$ ?? misschien Priaman en Indrapoera; immers door hem gesignaleerd, maar niet met name genoemd, als: *the other two kingdoms that are at the other side of the Island», dus op de Westkust]. (ed. Yule-Cordier, II, p. 284; 300).

In den gang van zijn verhaal is dus Bintan-«Malaiur» een excursie; niet een tusschenschakel tusschen Bintan en Perlak, zooals het emporium Malaka geweest zou zijn, als hij dat bedoeld had. Waar nu het emporium-zijn van de stad Malaka vóór 1400 nog hypothetisch is, en het emporium Palembang sinds ruim 6 eeuwen bestond toen Polo langs het onbewoonde Bintan heenvoer, om de groote Selat (Straat Malaka) in te zeilen, is het verhaal dat hij geeft over "Malaiur " blijkbaar iets dat hij aan boord hoorde vertellen. Hij vertelt over. Aangezien echter 
de staat Palembang reeds in den lateren tijd van I-tsing (ca. 692

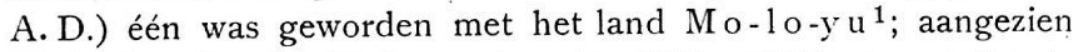
in de Annalen der $2^{\text {e }}$ Soeng-dynastie (960_1279; dus sluitende vlak vóór Polo's terugreis uit China over zee!) de koning van den staat Palembang zelfs doorgaat onder den titel van $* \mathrm{C}$ han pi» $=$ Djambi (Groeneveldt's Notes, $1^{\mathrm{e}}$ ed. 1876, p. 63; $2^{\mathrm{e}}$ ed. 1887, . p. 188); - zoo ligt het op ongezochte wijze voor de hand, om Polo's schijnbaar zonderling verhaal dat men éérst 60 mijl en daarna nòg eens 30 mijl moest zeilen om, van Bintan uit, Malaiur te bereiken, aldus te interpreteeren: na 60 mijl kwam men van Bintan bij oud-Malajoe $=$ Djambi $=$ hier de monding der Batang Hari; en na nòg 30 mijl verder kwam men in groot-Malajoe $=$ Palembang, het handels-emporium door hem nader beschreven. Als men de kaart van Sumatra dan bekijkt, en deze afstanden vergelijkt met de $100 \mathrm{mijl}$ die Polo vervolgens tusschen Bintań en Perlak (op Java Minor) stelt (zie boven), zoo zal men zien dat dit ruwe zeemans-gegeven toch héél aardig uitkomt voor Palembang, uiterst slecht voor Malaka.

Kortom: zoolang niet het bestaan van een emporium Malajoer = oud-Malaka vóór 1400 A. D., stellig bewezen is langs geheel andere wegen, blijft Ferrand's interpretatie van Polo's "Malaiur» een zéér zwakke uitleg.

III. Iets sterker als argument voor het bestaan van een Malajoer op het Maleische schiereiland in Polo's tijd, schijnt het vermelden in de Annalen der Yüan-dynastie (1280-1367), onder het jaar 1295, van het volgende gegeven, dat het eerst te berde

1 I-Tsing's ${ }_{n}$ A record of the Buddhist religion as practised in India and the Malay Archipelago (A. D. 671-695)", ed. J. Takakusu, Oxford 1896, p. 10: „Counting from the West [n.l. bij „the islands of the Southern Sea" = Indonesië] there is first of all P'o-lu-shi (Pulushih) island [= Baroes; Kern, 1897], and then the Mo-lo-yu (Malayu) country [= Djambi; Rouffaer, 1909] which is now the country of Srîbhoga (in Sumatra) [= Palembang; Beal, 1883], Mo-ho-sin (Mahâsin) island [Takakusu, p. XLVII gist: „may be the present Bandjermasin on the southern coast of Borneo"; doch in deze studie zal thans blijken: $\boldsymbol{M} \bar{a}-$ Hasin $=M \bar{a}-$ Toemasik = de "(Groote Zee-stad" Singapore], Ho-ling, (Kalinga) island (in Java), Tan-tan island (Natuna island)" . . etc. Verg. Pelliot, 1904, p. 338 en 348; Coedès, 1918, p. 9; Ferrand, 1918, I, p. 478. I-tsing schreef zijn Record in 691-692 (Takakusu, p. LV)., Voor de herkenning door S. Beal in 1883 van Çrîbhoja, zie Not. Bat. Gen. 1884, p. 21; Groeneveldt in Not. 1886, p. 7-9, met Beal's nota van 1883 aldaar afgedrukt als Bijlage I, of in anderen vorm opgenomen op p. 251-253 in Van der Lith \& Devic, Livre des Merveilles de l'Inde, Leiden 1883-86; vorg. Chavannes in zijn ed. van I-tsing, Les religieux éminents etc. (1894), p. 36 noot en 202-203. 
is gebracht door den Sinoloog Prof. P. Pelliot in zijn diepdoorwrochte, schitterende studie "Deux itinéraires de Chine en Inde à la fin du VIIle siècle» (Bulletin Ec. franç. d' Extr.-Or., IV, 1904, p. 131-413):

„La $1^{\text {re }}$ année yuan-tcheng (1295).... le royaume de Sien $[=\mathrm{Siam}]$ présenta une supplique en lettres d' or priant la cour [n.l. der Yüan-dynastie, onder den fameuzen Mongolen-Vorst Koeblai Chan; die o. a. in 1292, Polo's eigen reisjaar in Indonesië, zijn bekende tuchtigings-expeditie naar Oost-Java had uitgerust] d' envoyer une mission dans ce royaume [n.l. Siam].... On donna à l' envoyé une tablette en or uni pour qu'il la portât à la ceinture. L'envoyé s'en retourna immédiatement; un ordre impérial envoya une mission pour partir avec lui. Comme les gens du Sien s'entretuaient depuis longtemps avec les

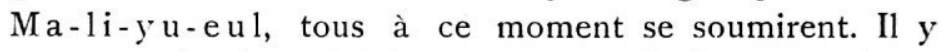
eut un ordre impérial disant aux gens du Sien: "Ne faites pas de mal aux Ma-li-yu-eul afin de tenir votre promesse.»" (p. 242).

Pelliot teekende hierbij in een noot aan: "Les Ma-li-yu-eul sont probablement les gens du Malaiur de Marco Polo; nous les retrouverons plus loin.» Op p. 328 en vlg. van zijn studie kwam Pelliot dan ook op dit Ma-li-yu-eul terug, en stelt het gelijk èn met den term $\mathrm{Mo-la-yeou} \mathrm{(naar} \mathrm{Fransche}$ transcriptie beide) die herhaaldelijk in deze zelfde Yüan-Annalen óók voorkomt (1281, 1293, 1299, 1301; zie Pelliot, p. 326-328; gereproduceerd bij Ferrand II, p. 83-85), èn met Marco Polo's Malaiur (aldus b.v. op p. 347: "J'ai admis que le Malaiur de Marco Polo, le Mo-la-yeou.ou Ma-li-yu-eul des Chinois, le Malāyu des Javanais n'était autre que Palembang en Sumatra»).

Maar hier nu gaat Ferrand een totaal anderen weg! Neen, zegt hij, na deze aanhalingen uit Pelliot; de Mo-la-yeou en de - met de Siameezen in 1292 allang vechtende - Ma-li-yu-eul zijn allerminst dezelfden! "Or aucun texte, aucune inscription ou tradition n'indique explicitement ou implicitement que les gens de Sien aient jamais fait des incursions à Sumatra. L'argument est décisif et il faut situer ces Ma-li-yu-eul ailleurs que dans la grande île indonésienne, (II. p. 86-87). En na dit twijfelachtig! - argument (want rept de Maleische Kroniek van 
Pasei-Samoedra niet juist wèl van strijd ter zee met een vloot uit Siam in ca. 1340; waarschijnlijk tijdens den Malik ath-Thahir, dien Ibn Batoetah in 1345-46 er ontmoet heeft?), komt hij, gerugsteund door het feit dat nà 1400 de stad en staat Malaka in herhaalden oorlog was met de Siameezen, tot de conclusie: „Les gens de Malaka sont donc des Malayo qui étaient "constamment en guerre» avec le Siam. Leur pays est limitrophe des possessions siamoises de la péninsule malaise. Il me paraît hors de doute que ces Malayo [genoemd door den Port. schrijver Braz d'Albuquerque, in zijn Commentarios van 1557 op het heldenleven van zijn vader] sont identiques aux $M a-l i-y u$-eul du Yuan che $\left[=\right.$ de Yüan-Annalen] qui, à la fin du XIII ${ }^{\circ}$ siècle, ${ }^{1}$ "s'entretuaient depuis longtemps» avec les gens du Sien = Siam." (II, p. 87-88).

Wat men maar «hors de doute» gelieft te noemen!

En zoo begrijpt men weer, dat Ferrand, na deze (zéér twijfelachtige) gelijkstelling van een slechts éénmaal in een Chin. bron voorkomend Ma-1i-yu-eul in 1295 met een vooralsnog hypothetisch oud-Malaka, emporium vóór 1400 ; alsmede daarna in zijn studie de zeer twijfelachtige, niet nader gevocaliseerde Arab. schrijfwijzen M.1.ā.ī.r. behandelend, of M.1.ā.b.r. (zie boven; Ferrand, II, p. 89-91); alsmede daarna Marco Polo's Ma la i u r duidend als oud-Malaka (II, p. 91-94) - komt tot deze conclusie: «Malaka n'a été que la continuation du Malayur de Marco Polo et du Yuan che dont la fondation est de beaucoup antérieure à la fin du XIII ${ }^{e}$ siècle, sans qu'il soit possible d'indiquer une date précise.» (II, p. 105).

Had Ferrand de baanbrekende studie van den heer Coedès een jaar eerder kunnen lezen, dan zou hij hier gewis geschreven hebben: de beaucoup antérieure au commencement du XI ${ }^{\mathrm{e}}$ siècle!

$\mathrm{Er}$ zal nu beproefd worden aan te toonen, dat «l'ancien Malaiy ū $r$ (avec) un fort situé sur une haute colline» (Coedès, p. 5) van de groote Tanjore-inscriptie uit 1030 A. D. moeielijk iets anders kan wezen dan het antieke Malajoe, d.w. z. de eeuwenheugende kota Djambi.

Het zal daarvoor goed zijn éérst hier nog eens af te drukken

1 Verg. de noot op blz. 4 hieryóór. Men ziet bovendien, dat de Siameezen toen in diplomatieke betrekking $\mathrm{kwamen}$ met het Chin. hof ; maar niet de Ma-li-yu-eul zelf. Op zulke en andere onnauwkeurigheden stuit men herhaaldelijk in de studie van Ferrand, 
mijn referaat dd. 19 Juli 1909 in de Bestuursvergadering van het Bataviaasch Genootschap, met welks hoofdinhoud Ferrand zich heeft vereenigd, terwijl Coedès bij zijn nadere behandeling van "Malaiyūr» (p. 9-10) er blijkbaar geen kennis van droeg. De drukfouten kunnen dan tevens nu worden verbeterd.

*b. In verband met de aanwezigheid dezer antieke inscriptie [n.l. te KKarang Brahi, aan den bovenloop van den Mrrangin, den zuidelijken bijstroom der Batang Hari (Djambi), een eindje bovenstrooms van Djelatang»; p. 115] in Boven-Djambi, en aansluitend bij tal van onderling onafhankelijke oude gegevens, is spreker voor zich zelf tot de stellige overtuiging gekomen, dat het Mo-lo-yu= Malajoe waar de Chineesche Hînajânistische monnik I-TSING in 672 of $673 \mathrm{~A}^{\circ}$. D. twee maanden vertoefde op zijn reis van China naar Kedah en Voor-Indië, via Bodja = Çrîbodja = Palembang (waar hij zes maanden bleef om Sanskrit te leeren), en daarna dat Mo-lo-yu aandoende voor twee maanden, niets anders kan gezveest zijn dan Djambi; gelijk hij in Deel IV ${ }^{1}$ der Encyclopaedie van Ned.-Indië, p. 201, i. v. "Sumatra" reeds vroeger aarzelend gemeend had beide te mogen gelijkstellen.

Het belangrijke van deze gelijkstelling is dan echter dit: dat het moederland van het Maleisch, Oer-Malajoe, vereenzelvigd moet worden met het stroomgebied.van de Djambi-rivier; Malajoe-proper met Djambi.» (Notulen Bat. Gen. 1909, p. 116-117).

En bij bovenstaande verwijzing naar de Encycl. v. N.-I. behoorde deze noot, die evenzeer ter zake van belang blijft:

"Men zie in dat deel IV (compleet gekomen in Dec. 1905) op p. 200-202 de chronologische lijst der HindoeSumatraansche inscripties, en de opgave der dito oudheden, tot 1903 bekend. Aldaar werd over I-TSING reeds gesproken als "naar "Malajoe» $=$ Djambi (?) gaande voor 2 maand", en voorts over "Malajoe $=$ (toenmaals nog) het Djambi-Palembang-gebied». Doch zeggen dat Malajoe $=$ Djambi moest zijn, durfde ik toen nog niet. Het oudste

1 Een paar keer in Pelliot's bovengenoemde studie van 1904, onjuist aangehaald als „t. II" (p. 282, noot 2), of als nt. III" (p. 328, noot 1; p. 340, noot 6). - De eerste druk der Encycl. is in afleveringen verschenen, 
gedocumenteerde jaartal op een zwaar stuk steen in Sumatra's binnenland, n.1. 986 Çaka $=1064$ A $^{\circ}$. D., ${ }^{1}$ komt toevallig net van de doesoen Solok, een westelijke kampoeng der kota Djambi! Het nog oudere (tot heden alleroudste) jaartal uit het hart van. Sumatra, n.1. 946 Çaka $=1024 \mathrm{~A}^{\circ}$. D., komt voor op een bronzen Lokanâtha-beeldje, dat dus weleer versleept kan zijn; dat dit evenwel een Hindoe-Sumatraansch beeldje is, blijkt uit de inscriptie in oud-Javaansch schrift maar met een Maleischen woordvorm.

Bij deze Hindoeïseering van Midden-Sumatra is méér dan de Moesi, of de Kwantan, of de Kampar, of de rivier van Siak (Tapoeng), of de Rěkan, de Batang Hari het groote verkeersmiddel geweest, óók naar Měnangkabau.» (1. c. p. 116).

$\mathrm{Nu}$ aan den heer Coedès de eer toekomt den naam Ma la i y $\mathrm{u} r$ der Tanjore-inscriptie teruggebracht te hebben tot het welbekende Malajoe - hij schrijft: "MALAIYŪr. Il s'agit évidemment du pays de Malāyu d'où les Européens ont tiré le nom des Malais ; en verwijst naar "toute une série d'hypothèses" over "la localisation exacte de ce pays», samengebracht en besproken door Pelliot, 1904, p. 326-333, en door Gerini in zijn befaamd boek "Researches on Ptolemy's Geography of Eastern Asia», 1909, p. 528-539 —, rijzen in het licht van bovenstaande, door den heer Ferrand overgenomen, gelijkstelling van I-tsing's Mo-lo-yu= Malajoe $=$ Djambi (I, p. 481 ; zie de aanhaling hiervóór, blz. 3), de twee volgende vragen:

$1^{\circ}$. Is inderdaad de kota Djambi zóó gelegen, dat de omschrijving in de Tanjore-inscriptie gerechtvaardigd mag heeten?

$2^{\circ}$. Zoo ja, is er dan een aannemelijke verklaring te vinden voor de verhaspeling van het inheemsche woord Malajoe, M a lā y u $=$ Djambi, in Malaiy ū $r$ op die Tamil-inscriptie van 1030 A. D.?

Tot beantwoording der eerste vraag wordt hierachter de terreinschets gereproduceerd van de kota Djambi in 1877, schaal $1: 20.000$, te vinden in D. D. VeTH's Atlas (Leiden, 1882) in het onder toezicht van zijn vader, Prof. Veth, uitgegeven werk "Midden-Sumatra», op kaart XI.

2 Niet "1086 A A $^{\circ}$ D." zooals er staat; en niet "Vlînajâhistische" te voren! Ook niet n(Tapoeng) Rĕkan" even verder. 


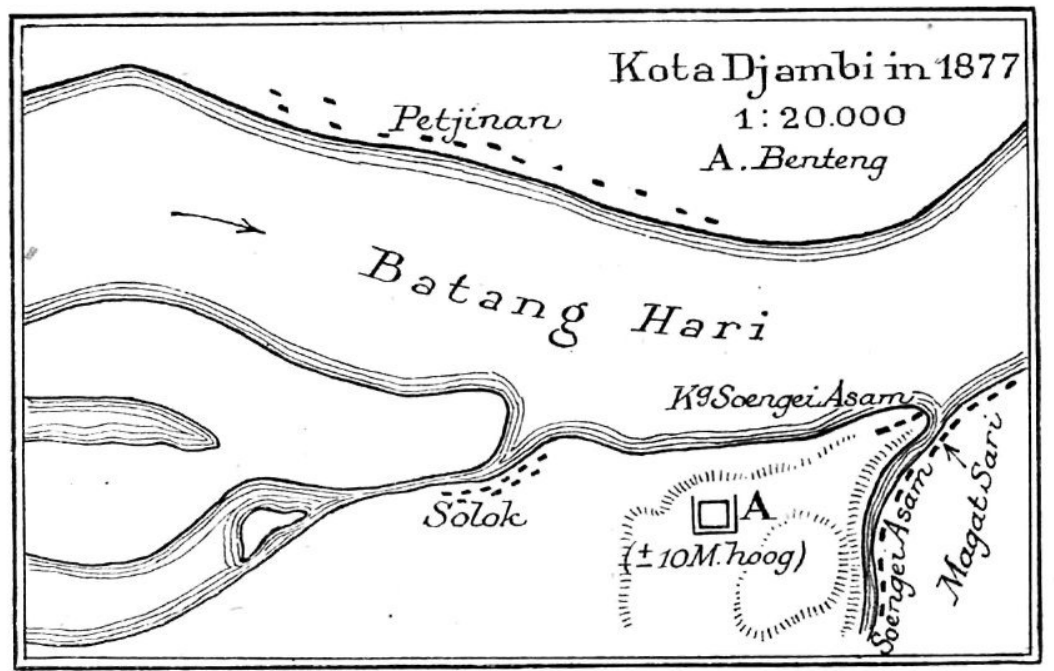

Men ziet hier, beter dan een beschrijving met woorden dat zou kunnen doen, en beter dan een latere plattegrond van de stad met haar moderne bijbouwingen en terrein-wijzigingen het ons zou kunnen toonen, de ouderwetsche kota Djambi nà de expeditiën van 1858; toen de eenige groote verandering was geweest dat de kraton van den Sultan van Djambi (Taha Safioedin, den lang daarna befaamd gebleven Sultan Taha), op 6 Sept. werd ingenomen en daarna geslecht, terwijl op de plaats van dezen de benteng voor den Holl. politieken agent werd gebouwd. Zoo wordt dan in het Reisverhaal, I (1881), p. 240, door A. L. VAN HASSELT de plek aldus beschreven in dat werk "Midden-Sumatra : "De benteng is gelegen op de plaats waar de voormalige kraton des Sultans stond. Zij ligt op ongeveer 15 meters boven de zee»; terwijl op p. 245-246 er aan wordt herinnerd, dat die kraton van den Sultan «in 1858 geslecht werd».

Op de terreinschets van D. D. Veth uit 1877 ziet men nu duidelijk den heuvel (van ca. $15 \mathrm{M}$. hoogte "boven zee» zegt de tekst; dus naar schatting $10 \mathrm{M}$. zoowat boven het maaiveld ter plaatse, want de zee is thans een $90 \mathrm{~K}$.M. hemelsbreed van de kota Djambi verwijderd), als beheerschende plek op den rechteroever der rivier, de Batang Hari; bij A de toenmalige benteng op den top van dien heuvel, de oude plek ook van den vroegeren Sultans-kraton; west daarvan, beneden den heuvel, de doesoen (= kampoeng) Solok, waar de antieke 4 makara's en het staande 
Boeddha-beeld resp. tot in 1902 en vóór ca. 1890 in loco nog voorkwamen, met op een der makara's het jaartal 986 Çaka bovenvermeld (zie voor de eerste 4 de foto's en de beschrijving door Dr. C. J. Neeb in Tijdschr. Bat. Gen. XLV, 1902, p. 120-127, met naschrift van Dr. Brandes, p. 128-133; alsmede voor de inscriptie Brandes in Notulen Bat. Gen. 1902 p. 34-35; voor den in ons Indië tot nog toe unieken staanden Boeddha, zie foto $\mathrm{n}^{\circ} 138$ in het Album (1879) van hetzelfde werk "MiddenSumatra», en mijn opmerkingen i. v. "Sumatra» in Encycl. v. N. I., $1^{\text {en }}$ druk, IV, 1905 , p. 202 b). ${ }^{1}$

In deze twee gegevens, den heuvel van de kota Djambi als centrum der oude stad, en de onmiddellijk ten Westen daarvan, aan den voet van dien heuvel, gelegen antieke doesoen Solok, met Boeddhistische - misschien zelfs deels oudere MahājānistischBoeddhistische - overblijfselen uit minstens de $11^{\mathrm{e}}$ eeuw A. D., slechts 34 jaar nà de groote Tanjore-inscriptie $(1064-1030=34)$, ligt voldoende "grond om te zeggen: zoodra men aannemelijk kan maken dat I-tsing's Mo-1o-yu $=$ Malajoe $=$ oud-Djambi uit ca. 692 A. D. - waarmee niet alleen Ferrand instemt, maar ook Dr. Krom in de recente heruitgave van Prof. Kern's vertaling der Nāgarakṛtāgama, 1919, p. 258 -, op een Tamil-inscriptie van 1030 A. D., verloopen kan tot den vorm Malaiyūr, dan is mijne gelijkstelling van dat (door Ferrand met eene hypothetisch emporium oud-Malaka vereenzelvigd) Malajoer $=$ oud-Djambi gewonnen.

Welnu, dit valt niet moeielijk te bewijzen als mogelijk en aannemelijk!

Coedès heeft hier zich zoo te zeggen aan de oplossing gebrand,

In een noot toch bij dat Malaiy ūr der Tanjore-inscriptie schreef hij: "Les données de l'inscription tamoule: "l'ancien Malaiyūr avec un fort situé sur une haute colline» n'éclairent pas beaucoup la discussion. Ces courtes descriptions qui accompagnent chaque nom de la liste reposent presque toutes sur des jeux de

1 Het staande Boeddha-beeld, met een lang gewaad dat om beide schouders heen naar beneden valt. bevindt zich sedert 1893 in 't Museum te Batavia (zie de geleidende p. 21-24 in Not. Bat. Gen. XXXI, 1893; voorts p. 64 over de ontvangst), en wel als no 233a, zooals pas incidenteel blijkt bij Brandes, Tijdschr. Bat. Gen. XLV (1902), p. 128! De zender in 1893 had het voor een Doergabeeld aangezien; doch te Batavia bleef men zwijgen. De anwinst der 4 makara's is geïnventariseerd in Not. Bat. Gen. 1902, p. CCXV-CCXVl. Zie volgende noot over de geheimhouderij met dit Boeddha-beeld; 
mots ou des étymologies fantaisistes. C'est le cas ici, où la "colline» (tamoul malai) n'apparaît sans doute que pour expliquer Malaiyūr. L'epithète "ancien» est plus suggestive: on pourrait la considérer comme un argument en faveur de la théorie d'après laquelle il $y$ aurait eu deux pays ayant successivement porté le nom de Matayu, et il s'agirait ici de l'ancien par opposition au nouveau.» (p. 9).

Men behoeft de lijn in 't midden van deze noot aangegeven, slechts dóór te trekken! Malaiy $\overline{\mathrm{u}} \mathrm{r}$ is wel Tamil malai $+\bar{u} r$; waarin malai $=$ heuvel, en $\bar{u} r$ : *Het in zooveel plaatsnamen van $Z$,-Indië voorkomende $\bar{u} r$, is een algemeen Drawidisch woord voor stad» (aldus Prof. Kern in zijn heruitgave van Linschoten's Itinerario, 1910, II, p. 131, noot 2).

Malaiy ū $r$ in de Tamil-inscriptie van Tanjore uit 1030 A. D. zou dus een ge-tamiliseerde, tevens symbolisch-opgevatte en symbolisch-omgevormde naam zijn van het goed-Maleisch-Javaansche Malājoe, Malajoe, en eenvoudig willen zeggen Heuvel-stad; geheel in den trant van de Zuid-Indische stedennamen - zie daarvoor nader Hobson-Jobson, $1^{\mathrm{e}}$ ed. 1886; of $2^{\mathrm{e}}$ ed. $1903-$ Mangaḷ-ūr of Mangalore, Kaṇnan-ūr of Can(n)anore, Nall-ūr of Nellore, Kaḍal-ür of Cuddalore, waarschijnlijk ook Tañjāv-ūr of Tanjore-zelf, Vakkan-ūr of Bacanore, Basr-ūr of Barcelore, enz.

$\mathrm{Nu}$ hiermede het Mo-lo-y u van den Hinnajānistischen Chin. monnik I-Tsing uit het eind der $7^{\mathrm{e}}$ eeuw, met $90 \%$ waarschijnlijkheid identiek is geworden aan "l'ancien Malaiy $\bar{u} r$, alias "de oude Heuvel-stad», zooals de Tamils van 1030 dat oude cultuurcentrum $\mathrm{Mal} \overline{\mathrm{a}} \mathrm{j}$ oe $=\operatorname{de} k$ kota Djambi op hun manier omgedoopt hadden in een voor hen verstaanbaren, en in elk geval niet onlogischen plaatsnaam ${ }^{1}$, ligt het voor de hand de volgende conclusies te trekken:

1 Een moderne beschrijving der kota Djambi gaf Contr. W. H. Kedchenids in Tijdschr. Binn. Best. XLIII (1912), p. 269: „Op dẹn hoogen rechter-oever der Batang Hari angelegd met een uitgestrekt vergezicht op de rivier, maakt het stadje met zijn breede wegen, die als linten door lage terreinplooien tegen bebouwde heuvels opslingeren, zijn park en zijn typische vlotwoningen een allervriendelijksten indruk." En over den lagen linkeroever (verg. Veth's terreinschets uit 1877) schrijft hij: ${ }_{n}$ Aan den linker-oever der Batang Hari, tegenover de Europeesche en Chineesche vestigingen, liggen voornamelijk de woningen der inlandsche becolking." (p. 270). De ouderwetsche toestand was anders; tot 1858 lagen de voorname inlandsche vestigingen hoofdzakelijk op den hoogen rechteroever: de kraton; de mĕsigit (in de doesoen Solok); de kampoeng der prijaji's (vandèàr geheeten doesoen „Magatsari") 
$1^{\circ}$. die bijvoeging van "oud» bij het Malaiyū $\mathrm{r}$ behoeft volstrekt niet te impliceeren, dat er toenmaals ook een nieuw-Malajoer ergens elders bestond, zooals Coedès min of meer aan de hand doet. De meest eenvoudige verklaring is toch deze, dat het epitheton "oud» gewoon constateert wat de waarheid was in 1030 (blijkens 1-tsing) en aan Tamils en Maleịers gelijkelijk bewust was. Djambi was dan, óók voor hen, "het moederland van het Maleisch,

aan de andere zijde d.w. z. benedenstrooms en Oost van den kraton; terwijl de Vreemde Oosterlingen (Chineezen, Arabieren, Palembangers) aan den linkeroever woonden in de doesoen Pĕtjinaän. Zeer aanschouwelijk voor de hoogte van den heuvel waarop vroeger de kraton, na 1858 de Holl. benteng stond, is foto 133 uit het "Photographie-Album" (1879), behoorende bij het werk Midden-Sumatra, en gevende de bovengenoemde doesoen Magatsari, gelegen aan de Soengei Asam, onmiddellijk Oost van het heuvel-complex der kota Djambi (verg. de terreinsehets op blz. 14 hiervóór); naar de afmetingen der inlandsche huizen gerekend, is de hoogte ran het ravijn der Soengei Asam een 9 à $10 \mathrm{M}$., bij blijkbaar lagen waterstand van de Batang Hari (die enorm in hoogte gedurende de verschillende jaargetijden kan wisselen; " tot 7 meters" toe, blijkens het Reisverhaal, I, 1881, p. 241).

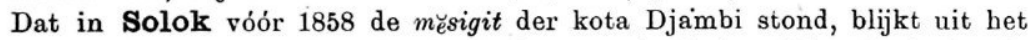
rapport „Jambi" van Captain S. C. CRooke uit Sept. 1820, afgedrukt als Appendix III in J. Anderson's "Mission to the East coast of Sumatra in 1823" (Edinburgh-London 1826, p. 387 vlg.), ook al noemt Crooke geen naam "Solok". In dat rapport toch constateert Crooke dat hij eerst „ at the entrance of the mosque" (n.l. van "the town of Jambi") op een steen van ca. 5 Eng. voet lang een verminkt hoog relief vond van een zittend ${ }_{r}$ Hindoo image" met glorie achter het hoofd, en $n^{\mathrm{a}}$ high ornamented head-dress" (dus: een Bodhisattwa-beeld?); welke éerste vondst "terminated in the discovery of several others" (p. 395), en wel: $2^{\circ}$. "the statue of a man, the arms broken off, about five feet high, in an erect posture. The head... had a somewh at feminine appearance... the hair was eurly, in little round knobs, and formed into a knot" (p. 395-396); dit is dus de sta ande Boeddha van andesiet, tot heden een unicum in onze Oost, verg. Dr. Bosch in Tijdschr. Bat. Gen. LVII, 1916, p. 104-105; die in 1893 door den politieken agent te Djambi, H. J. A. R R van Oldenbarneveld, naar Batavia werd gezonden als een "vrouwenbeeld", wellicht "Doerga", met een foutief alibi, alsof dit beeld vóór 1890 uit Moeara Djambi zou zijn gekomen (Notulen Bat. Gen. 1893, p. 22--23), en waar Dr. Krom in $1914 \mathrm{nog}$ is ingeloopen (Oudheidk. Verslag 1914, p. 131); dat daarop in Maart 1893 te Batavia werd ontvangen (Not. B. G. p. 64; niet bij Krom; en foutief "60" in V. d. Chijs' Register op de Notulen 1889-1598, p. 38); dat toen door den President van het Bat. Gen., tevens Conservator van het Archaeologisch Museum, W. P. Groeneveldt, werd ingeschreven als n ${ }^{\circ} 233 a-$ d. w. z. als een vervolg-nummer op $\mathrm{n}^{\circ}$. 233, een Boeddha-buste (gemutileerd, en daardoor niet zeker) uit Pĕrtibi in Tapanoeli -, maar.... niet werd opgenomen in de jaarlijksche gedrukte Lijst van Aanwinsten (zie, of liever: zie niets, l. c. p. CXCVIII), omdat,.. . ja, omdat de heer Groeneveldt zich zoo Dl. 77. 
Oer-Malajoe», zooals ik in 1909 durfde schrijven; niet in den zin, zooals Ferrand daaruit meende op te maken en, in die meening, zulks terecht bestreed; II, p. $123-$ dat de Maleiers "aborigènes» van Sumatra zouden zijn geweest; maar wel in dezen zin, dat het Maleisch als afzonderlijk Indonesisch idioom, door het antieke overwicht van de stad en den staat Djambi, zijn geboorte dankt aan die Batang-Hari-streek; op gelijke wijze als het Castellano zijn moederland had in Kastilië, het Hollandsch in Zuid- en Noord-Holland, het Maleisch dus in "Malajoeproper» $=$ Djambi (en niet b.v. in Palembang, of in Minangkabau, of op Bintan alias Riouw, of ergens op het Maleische Schiereiland). ${ }^{1}$

$2^{\circ}$. de volgorde in de Tanjore-inscriptie van 1030 (verg. hiervóór, blz. 7) wordt dan ook logisch; na Kĕdah (Kạ̣āa ram) als $n^{\circ} 1$, immers geweldig te land door strijdmacht, éérst het rijke emporium Palembang (Çrīivija y m) als $n^{\circ} 2$;

enorm in zïn vinger had gesneden met zijn Palembang-Djambi-advies uit 1885 contra Beal, afgedrukt in Notulen Bat. Gen. 1886, p. 7-9 (en verg. er Beal's baanbrekende nota van 1883 , als Bijlage I); $3^{\circ}-6^{\circ}$. „four figures representing an elephant's head with tusks, the trunk curled upwards and backwards... These seemed to occupy their original situation in the skirts of the town; but no ruins were seen near them. The others were found in different places, whither they had been carried" (p. 396; dit zijn de 4 makara's in de doesoen Solok, waarvan een met een korte inscriptie in Oudjav. letters en het jaartal "i çaka 986", waarvan alleen de 6 onzeker is; en die alle 4, dank zij Dr. C. J. NeEB, sedert 1902 in 't Museum te Batavia berusten als $\left.n^{\text {os }} 459, b-e\right) ; 7^{\circ}$. "a bull about half the natural size, kneeling ... remarkably well proportioned and executed" (dus een nandi; soms uit den tijd der Pamalayu, ca. 1200 Çaka?). Den verminkten Bodhisattwa(?) vond Dr. Neeb ook in 1902 nog terug, en fotografeerde hem, waardoor Dr. Brandes kon zeggen, dat dit fragment "nog de meesterhand verradende" was (Tijdschr. Bat. Gen. 1902, p. 129). Den nandi van 1820 trof Dr. Neeb niet meer aan; maar daarentegen vond hij bovendien een dagob. De Djambiërs van 1820 noemden deze relieken van hun voorvaderen, meest wel Boeddhistische, deels ook Ciwaïtische Maleiers in de $11^{\circ}-14^{\circ}$ eeuw A. D.: „chessmen (buah chatoor) of the giants or genii" (p. 396). Quantum mutati ab illis!

Over de eigenlijke kota-Djambi, of den kraton daarbinnen, zegt Crooke helaas niets. Want "The mission... did not reside at the town" (p. 387); men was 2 mijl benedenstrooms blijven liggen.

1 Deze stelling impliceert natuurlijk, dat er ook een andere, oudere, term (soms: $k i d a l=k i d o e l$ ? zie hierna blz. 71) alsnog aangetoond zal moeten worden voor het tegenwoordig Mal. sŭlatan = het Zuiden (letterlijk: de „kant" of "richting" der Sělat = de Straat Singapore). Voor het $\mathrm{N}$. heeft het Mal. 2 termen: het Skr. oetara, en het inheemsche laoet $=$ Jav. lor $=$,zee". 
dàn het aan een rivier gelegé Panei (Paṇnai) als n $n^{\circ}-$ men denke aan den vischrijkdom van Bengkalis in de $16^{\mathrm{e}}$, van Bagan Si Api-Api in de tegenwoordige eeuw -; en dan het antieke Djambi (Malai y ūr)als n ${ }^{\circ} 4$. Daarnà pas gaat de inscriptie over op de door den Chola-Tamilvorst onderworpen staten op het Maleische Schiereiland.

$3^{\circ}$. het "Malaiur» van Marco Polo uit 1292 is niets anders zeker dan een ge-tamiliseerd Malajoe, door Polo opgevangen op het schip dat hem van Zuid-China, via Noord-Sumatra, bracht naar Voor-Indië. En het emporium Malājoe(r) van toenmaals was het reeds sinds ca. $700 \mathrm{~A}$. D. politiek en commercieel oppermachtig geworden Çrīwidjaja $=$ Palembang (eere Coedès!), maar niet oud-Malājoe $(r)=$ Djambi. Alleen in die rare $60+30$ mijl van Polo's afstands-bepaling (zie hiervóór, blz. 8-9), is wel nog een overblijfsel te herkennen van èn oud-Malajoe $=\mathrm{Djambi}$, èn groot-Malajoe $=$ Palembang.

$4^{\circ}$. de Ma-li-yu-eul uit de Annalen der Yüan-dynastie van 1295 , die toen gedurig aan 't vechten waren met Siameezen, waren òf heusche Djambiërs, ò - en veel waarschijnlijker - Palembangers. Is dit laatste inderdaad zoo, dan zijn de door Pelliot in 1904 aan het licht gebrachte gegevens uit de Annalen der Yüan-dynastie over Mo-layeou en Ma-li-yu-eul (beide in Fransche spelling) van resp. 1281-1301 en 1295 (zie hiervóór blz. 10) eenvoudig in te voegen tusschen de gegevens die Groeneveldt in zijn Notes (1 ${ }^{\text {e }}$ druk, 1876 , p. $62-73 ; 2^{\text {e }}$ druk, 1887, p. 187-197) over San-bo-tsai $=$ Sambodja $=$ Palembang heeft gepubliceerd uit resp. de Annalen der (2 $2^{\mathrm{e}}$ ) Soeng-dynastie (9601279) en die der Ming-dynastie (1368-1643); waarbij dus juist de (Mongoolsche) Yüan-dynastie (1264-1367) door Groeneveldt was overgeslagen, omdat hem de identiteit van Mo-la-yu, Ma-li-yü-ěrh en San-bo-tsai was ontgaan.

Uit het voorgaande is duidelijk gebleken, dat het eindoordeel over Ferrand's studie "Malaka, le Malāyu et Malāyur» in haar quintessence met $90 \%$ waarschijnlijkheid wel zal moeten luiden: onaannemelijk.

Toch moeten wij hem ten zéérste dankbaar blijven, dat hij 
met zóóveel buitengewone kennis en methode en vlijt een schat van gegevens heeft bijeengebracht over die voor de geschiedenis der $14^{\mathrm{e}}-15^{\mathrm{e}}$ eeuw A. D. zoo hoogst gewichtige Indonesische vraag: wanneer is de stad Malaka dan toch gesticht?

Het is, zooal niet onmogelijk, dan toch weinig waarschijnlijk, dat Malaka, hetwelk blijkens de Annalen der Ming-dynastie (Groeneveldt, Notes 1876, p. 129-130; of 1887, p. 248-250) in 1403 nog "belonged to Siam», van 1405-1413 een blijkbaar Hindoeistisch onafhankelijk heerscher had met den vermaleischten Sanskrit-titel Perrmaisoera (Pai-1i-su-ra), ${ }^{1}$ en dat pas in 1414 een blijkbaar Islamietischen vorst kreeg (Mu-kan-sa-u-ti-r-sha $=M_{\text {e gat }}{ }^{2}$ (?) Sĕkandar (??) Sjah), terwijl diens zoon als optredende jonge vorst in 1424 zich zoowaar al tooide met den weidschen titel Cri Maharadja (Si-li-ma-ha-la), - het is weinig waarschijnlijk, dat dit Malaka zóó plotseling tusschen 1400 en 1425 van een aan Siam onderworpen kustplaatsje, dat in 1409 pas stadsrechten kreeg door den Chin. gezant Cheng Ho (zie Groeneveldt, p. 123 of 243), opbloeide tot een Moslimsch emporium, hetwelk gedurende de heele $15^{\mathrm{e}}$ eeuw èn handel èn politiek èn islamitiesche geloofs-propaganda in de Westelijke helft van den Maleischen Archipel heeft beheerscht. Onmogelijk is het wel niet - de stichting van het dadelijk oppermachtige Madjapahit in 1214 Claka $=1292$ A. D. is een frappant voorbeeld van het tegendeel ${ }^{3}$-, maar weinig waarschijnlijk blijft het.

Véél waarschijnlijker is, dat Malaka als vrij onbeduidende plaats van visschers en ó́k wat scheepvaart - welke laatste o. a. water kwam halen op de 5 eilandjes beneden $(=\mathrm{Z}$. O.) van de monding der soengai Malaka gelegen; de $\mathrm{Wu}-\mathrm{hs}$ ü of "Five Islands» van het Chin. bericht uit 1416 bij Groeneveldt, p. 123 of 243 - in de heele $14^{\mathrm{e}}$ eeuw ook wel degelijk bestaan heeft. Maar dat het dan vóór 1365 van den, zeg, $3^{\text {en }}$ rang bleef, dàt bewijst onwederlegbaar de Nāgarakěrtāgama vaan dat jaar, waarin op het heele schiereiland Pahang $=$ de Aurea Cher-

\footnotetext{
1 Verg. het thans nog levende Mal. perrmaisoeri $=$ Koningin, $1^{\circ}$ Gemalin van den Vorst (Oudjav. parameģwari).

${ }^{2}$ Mal. Megat is iets als Eng. Fitz; zeg: prinselijke bastaard, waarbij de moeder hooger was in rang. Verg. den Oudjav. titel S a měgat, Pa měg ět.

3 Een tweede frappant voorbeeld, uit den eigen tijd van Malaka's opbloei, is de stichting van de hoofdstad van Guzerat (Gujarāt), Ahnadābād, door Ahmad Sjāh I, in 1412; zie hierna noot 1 op blz. 23. Deze stiehtte er ook een groot deel der Moh. bouwwerken, waarom Ahmadābād nu nog beroemd is.
} 
sonesus, niets wordt vermeld omtrent een door Madjapahit onderworpen "Malaka», maar wèl wordt genoemd een onderworpen Moear (Paka, Muwar), een onderworpen Singapore (Tumasik), enz. Slechts indien het gelukken mocht om in een van de 5 of 6 nog niet afdoend te localiseeren Schiereiland-namen in Zang 14 van dat Oudjavaansch lofdicht (Saimwang, Naçor, Sanghyang Hujung, Jěre, Kañjap, en (?) Nirān; zie ed. KernKrom, 1919 , p. 51 en 260, alsmede de kaart), alsnog een oudMalaka te identifieeren, dan zou het gezegde afdoend gegeven omtrent Malaka's onbeduidendheid in dien tijd moeten wegvallen.

De eenige gezonde weg nu om ten minste het bestaan van het oord Malaka vóór 1400 aan te toonen, is het systematisch zoeken naar dien naam in vertrouwbare, en liefst onderling onafhankelijke, gegevens uit de $14^{\mathrm{e}}$ eeuw of vroeger.

Twee daarvan schijnen voorloopig ten dienste te staan; buiten de zooveel latere Portugeesche gegevens, die het onderling bovendien wanhopig oneens zijn, zooals Ferrand in het eerste gedeelte van zijne studie overvloedig heeft aangetoond (I, p. 406-453, en 469-470).

De Pararaton (ed. Brandes, Verh. Bat. Gen. XLIX, $1^{\text {e }}$ stuk, 1896) geeft bij het jaar 1250 Caka $=\mathbf{1 3 2 8}$ A. D. - d. i. dus 35 jaar na den terugkeer der Fav. troepen op Oost-Java; uit Toemapěl $=$ Singasari op last van Vorst Kërtanagara in 1197 Caka vertrokken om Malayu (= Djambi-Dharmāçraya-Minangkabau) te veroveren, en bij dien terugkeer in 1215 Ç. medebrengende als levenden buit o. a. tzvee Maleische prinsessen (tekst p. 24, Brandes' vertaling p. 76) -, ineens zònder verband met wat voorafgaat of wat volgt, het volgende curieuze kroniek-bericht:

*Tuhan Wuruju was een dezva-putra van Pamellekahan; als deze met zijn zweep klapte, dan hoorde men het overal, en schrikte men er te Majapahit van.» (p. 119; tekst op p. 28: "Tuhan Wuruju dewaputra saking Pam`lěkahan, lamun añjēplakakěn pěpěcut, karungu ing antarikșa. Kaget wong Majhapahit.»)

Brandes heeft zich over dezen schijnbaar-zonderlingen inwerp in den tekst niet verder uitgelaten; slechts in zijn Register op de in den Pararaton voorkomende plaatsnamen teekende hij nog aan: "Pamẹlekahan, ... misschien geen plaatsnaam» (p. 224a).

Beziet men dezen zin echter nauwkeurig: het tuhan, dat op 
een Maleier wijst; dat zuruju (woeroedjoe), dat - blijkens v. d. Tuuk's Kawi-Wdb. III, 1901, p. 489b - beteekent "de jongste», jong-Jav. waroedjoe, van Skr. avaraja, en in 't Maleisch van Palembang (let wel!) levend als beroedjoe $=$ Mal. bo(e)ngsoe; voorts dat suggestieve $\mathrm{Pamělěkahan,} \mathrm{dat} \mathrm{voortreffelijk}$ "M Ælaka(h)-land», kan beteekenen; - dan mag men, zonder spitsvondig te worden, onderstellen: dat men hier te doen heeft met een Maleier uit Malaka-land, jongste zoon van een aanzienlijke of Kṣatriya (dewa), in 1293 A. D. als knaap medegebracht onder den levenden buit uit het Djambi-Minangkabau'sche, daarna opgegroeid te Madjapahit als een soort anak mas, en die nu in 1328 A. D., (dus als ca. 40-jarige Maleier uit Malaka) de lieden te Madjapahit deed schrikken door zijn geweldig zweep-geklap; zóó geweldig - en vrage zelfs : zóó symbolisch-dreigend soms??-, dat de Koningen-kroniek der Pararaton er niet over kon zwijgen.

Dit gegeven is op zichzelf nog volstrekt geen bewijs; maar toch een eerste kostelijke aanduiding voor een oord "Malaka», dat al in ca. 1290 A. D., op den Maleischen overwal bestond. ${ }^{1}$

Het tweede gegeven verschaft het boek van GERINI, Researches on Ptolemy's Geography of Eastern Asia, 1909, p. 531-532. Hij schrijft daar:

"The «Koṭ Moṇthierabān» (Kața Mandira-pāla) or "Palatine Law» of Siām, enacted in A. D. 1360 by the king who had a decade before founded the capital Ayuthia (Ayuddhy $\bar{a}$ ), gives full lists of the States then tributary to Siām, both in the north and south. Among the States of the south (Malay Peninsula) ${ }^{2}$, one bearing the name of Matay $\bar{u}$ is mentioned, the order being as follows: -

(1) Ujōng Tänah (known afterwards as Johor).

(2) Malākà (= Malacca).

(3) Matāy $\bar{u}$.

(4) Worawā̄ì (Varavārī = Muār ? . . .).

Total, four States.»

Of nu hieruit geconcludeerd mag worden, zooals Gerini hardnekkig hier - en elders - weer doet, dat er dus in 1360 A. D. bestond "a State named Maläyu or Matayy $\bar{u}$ in the south of the

1 Zie thans de in Dec. 1920 verschenen $2^{\circ}$ ed. Brandes-Krom, Verh. Bat. Gen. LXII; tekst p. 35-36; vertaling p. 140-141, met noot 18; en p. 254a.

2 Dit "(Malay Peninsula)" is natuurlijk Gerini's persoonlijke verklaring. 
Malay Peninsula» (p. 532), mag, na al het voorgaande, wel overgeslagen worden; $\mathrm{m}$. i. wordt met dezen naam óók weer òf Djambi, ò (en meer waarschijnlijk) Palembang bedoeld. Het bewijs, dat deze 4 genoemde staten op het Maleische Schiereiland moeten gelegen hebben, en niet ten deele in de onmiddellijke buurt daarvan gezocht mogen worden, blijft Gerini ons schuldig; ook blijkt bij hem volstrekt niet, dat het jaartal 1360 A. D. voor die Siameesche Paleis-wet nu ook volkomen vertrouwbaar zou zijn. Maar wel blijkt daaruit, dat in een Siameesche rechtsbron, die van 1360 , en dus a fortiori van vóór 1400 kan zijn, behalve Oedjoeng Tanah en oud-Palembang(?), ook worden genoemd als aan Siam schatplichtige staten: een "Malaka»- wat dus mooi klopt met de Chineesche gegevens, hiervóór (blz. 20) in 't kort herinnerd — ; en een raadselachtig W o r a wā $\mathbf{r} \bar{i}($ Varavārì), waarover straks nader gehandeld zal worden.

Het gegeven uit de Pararaton, teruggaande tot ca. 1290 A. D., alsmede dit Siameesche gegeven uit $\mathbf{1 3 6 0}$ (?), pleiten er dus samen voor, dat er inderdaad reeds eerder een Malaka met dien eigen naam (en niet onder eenigen anderen schuilnaam) op de Maleische Chersonesus heeft bestaan; dat echter pas in ca. 1414 onder invloed der bekeering tot den Islām van zijnen Vorst, en zulks weer gewis onder rechtstreekschen invloed van de met Moezafar Sjāh I (1394-1411) geweldig voor het eerst opgebloeide Moh. macht der zeevarende Guzeratten ${ }^{1}$ - die in de $15^{\mathrm{e}}-16^{\mathrm{e}}$ eeuw de machtigste propagandisten van den Islām in geheel onze Oost zouden worden! - van aanlegplaats der $3^{\mathbf{e}}$ orde groeide tot emporium van den $1^{\mathrm{en}}$ rang, immers tot rendez-vous der schepen van Oost (Molukken, Java, China, Oostkust der Chersonesus) en West (Goedjrat, Arabië, Malabar, Koromandel, Noord-Sumatra), die dààr hun overlaad-plaats kregen.

1 Zie o. a. het Chapter X, Muhammadan India (p. 350-413; door W. Irvine) in The Imperial Gazetteer of India, New ed., II (1908), en daar p. 376-378 speciaal over de geschiedenis van Gujarāt tusschen 1391 en 1572 ; deze eerste Moh. vorst van G., die het land onafhankelijk had gemaakt van Delhi (waaraan G. sedert 1196 onderworpen was geweest) was zelf zoon van een tot den Islām bekeerden Radzjpoet. De tweede Vorst, die G. groot en machtig makkte, was Ahmad Sjāh I (1411-1443), welke Ahmadābād in 1412 stichtte als-hoofdstad. - Merkwaardig in dit verband is, dat de éerste Sultan van Malaka zich noemde... Soeltan Moezafar Sjah, welke volgens de Chin. berichten geregeerd schijnt te hebben van ca. 1450-1458 ( ${ }_{n}$ Sulthan Wu-tafu-na-sha" bij Groenereldt, 1876, p. 131-132, of 1887, p. 251; Mal. Soeltan Moedhafar Sjah; Port. Soltão Modafaixa). 
En bekijken we dan nog eens weer de elkaar zoo wanhopig tegensprekende gegevens omtrent de stichting van Malaka bij de verschillende Portugeesche koloniale historici, in het licht van het bovenstaand - geenszins definitief, maar dan toch voorloopig vertrouwbaar - resultaat, dan bemerkt men tot zijn genoegen dat die tegenspraak meer schijnbaar is, dan wezenlijk.

Want, met uitzondering van den hoogst ònvertrouwbaren geschiedschrijver GASPAR CORREA - aan wien helaas de heer Ferrand vertrouwen juist heeft geschonken in zake de stichting van Malaka! - kan men zeggen dat er eigenlijk 3 lezingen bij hen zijn over die stichting. $\mathrm{Zij}$ mogen hier overzichtelijk bijeengebracht worden, met vermelding van het jaartal der drukken van de $1^{\mathrm{e}}$ edities, dan wel (zooals bv. voor Godinho de Eredia geldt) het jaar der afsluiting van het handschrift. Bovendien kan hier nog een ander werk van denzelfden, te Malaka geboren en getogen, Indo-Portugees Eredia in rekening worden gebracht, dat aan de aandacht van Ferrand is ontsnapt (verg. bij hem I, p. 467-472); alsmede Varthema's Italiaansch gegeven.

A. - Stichting van Malaka in 't midden der $13^{\mathrm{e}}$ eeuw (conform Valentijn; d. w. z. conform de Sadjarah Malajoe!): $1^{\circ}$. Barkos (Decada II, 1553; Lib. VI, cap. 1): ca. 1250.

B. - Stichting van Malaka in't midden der $14^{\mathrm{e}}$ eeuw: $1^{\circ}$. Couto (Decada IV, afgesloten in hs. Dec. 1597, $1^{\text {e }}$ druk 1602; Lib, II, cap. 1): ca. 1350 ; immers ca. 1384 (als jaar dat de eerste "Moorsche» Vorst optrad) min nog den regeertijd van 2 Radja's daarvóór, die geen Moh. waren.

C. - Stichting van Malaka om en bij 1400 (conform de Chineesche gegevens!): $1^{\circ}$. Eredia (Informação da Aurea Chersoneso, blijkens interne gegevens te Malaka afgesloten 1599; ed.Caminha, Lisboa 1807, p. 68) : $\mathbf{1 3 9 8}^{1} ; 2^{\circ}$. opnieuw EREDIA (Malaka, etc., dd. Goa, 27 Nov. 1613; ed.-Janssen, Bruxelles 1882 , tekst p. $4 a, 4 b, 22 b, 23 b, 38 b$, of. Fr. vertaling p. 1 ,

\footnotetext{
1 Deze tekst luidt: $„ \ldots$ en Malaka werd gesticht door Parameçwara, een Javaan van Balambangan [sic!], in het jaar 1398, ten tijde van Koning D. João den $I^{\text {en }}$ genaamd den Bastaard [regeerde 1385-1433], volgens de Maleische Annalen [sic]" (... e Malaca foi fundado por Parimiçura Jao de Balambuan no anno de 1398, em tempo de ElRei D. João o I. chamado o Bastardo, conforme os annaes Malaios). Eredia was een halfbloed van een Port. vader en eene Boegineesche moeder (dochter van een Radja van Soepa).
} 
$2,23,25,43,{ }^{1}$ dus niet minder dan 5 maal): 1411 ; 3 '. Braz, alias Affonso, de Albuquerque (Commentarios, 1557 ; Lib. III, cap. 17): in ca. 1421 wordt Malaka onafhankelijk van Siam; 4․ VARThema (Itinerario, 1510; Cap. 96): in ca. 1425 wordt Malaka gesticht door den Vorst van China. ${ }^{2}$

Schrikwekkend daarnaast zegt alléén CORREA (Lendas, afgesloten ca. 1563; ed. Lima Felner, II, Lisboa 1859, p. 221): $\pm \mathbf{8 0 0}$ A. D. Doch hem zullen we voorloopig ter zijde laten! Bij nader kritisch toekijken, blijkt al dadelijk dat Couto's getuigenis - die nog wel zegt dat hij verbeteringen aanbrengt in de gegevens van zijn voorgangers, de historici Barros, Albuquerque, en (?) Goes - als tastbaar onjuist uitgeschakeld moet worden; immers, hij stelt het aan de regeering komen van den eersten Moh. vorst te Malaka op ca. 1384, terwijl we dank zij de Chin. gegevens bij Groeneveldt! - beslist weten, dat dit pas in 1414 ongeveer gebeurd is. Couto moet dus feitelijk tot rubriek $\mathrm{C}$ worden gerekend; wat te merkwaardiger is, omdat hij overigens in zijn tekst gegevens en namen verwerkt, die blijkbaar ontleend zijn aan een Maleische bron, het prototype van onze tegenwoordige Sadjarah Malajoe, waarbij juist A (Barros) zich zoo opmerkelijk nauw alreeds aangesloten had vóór 1553.

Er blijven dus eigenlijk maar 2 lezingen over: A. die van Barros (1553), de Sadjarah Malajoe (met hoogst verdachten datum: Donderdag [sic] 12 Rabioelawal Dal [sic] $1021=$ Zondag [sic] 13 Mei 1612; terwijl 1021 Hidjra volstrekt geen jaar “Dal» was, doch een jaar Djim(awal), d.w. z. 2 jaar vóór Dal), en Valentijn (V, $1^{\text {e }}$ Stuk, 1726, fol. 316-320 en fol. 352; welke met nadruk zegt dat hij 3 (of 4 ?) Maleische bronnen, n.l. de Makota sěgala Radja-radja, de "Misa Gomitar»= de Mesa Goemětar $=$ één der Mal. Pandji-romans (maar welke?), de Hang

1 Ferrand (I, p. 448, en p. 450 noot 2) vermeldt dit „1411" in Eredia's tekst slechts 2 maal. Zijn bibliographische opgaaf over Barros' 4 Decaden (I, p. 431 noot 1) is fout; de jaren zijn: 1552, 53, 63, en 1615. En geheel ten onrechte plaatste hij Albuquerque's tekst (1557) vóór dien van Barros (1553), op resp. I, p. 411-428, en p. 431-438.

"Ludovico di Varthema beweert zelfs in ca. 1505 het Moh. "Melacha" tweemaal, als Pers vermomd, korte dagen te hebben bezocht; Cap. 96 en 110. $\mathrm{Hij}$ is de oudste Eur. getuige; in voorjaar $1508 \mathrm{kwam}$ hij te Lissabon uit Cananor terug; in Dec. 1510 verscheen zijn Itinerario te Rome. De nummering der Capita is van mịzelf, waarbij gebruikt werd de herdruk der $2^{\circ}$ Italiaansche editie (Venetië, Maart 1517) door A. Bacchi della Lega, Bologna 1885. 
Toewah, en de "Soelalet Essalathina»= de Sadjarah Malajoe volgt, blijkbaar vooral de laatste (verg. ook Ferrand I, p. 454); en C. die van Varthema (1510, wel in 1506 opgevangen te Cananor), Albuquerque (1557), Couto (1597), en Eredia (1599; 1613).

A. zegt: midden $13^{\mathrm{e}}$ eeuw; C. zegt: ca. 1400 . Welnu, beide lezingen mogen waarschijnlijk waarheid worden geacht! Doch de eerste geeft de éérste stichting als oord, als vlek; de tweede geeft den aanvang van den opbloei, de opkomst als emporium.

Malaka zoude alsdan een $1 \frac{1}{2}$ eeuw bestaan hebben als stichting van Maleiers uit Singapore - waarover zoo dadelijk nader gedurende de heele $14^{\mathrm{e}}$ eeuw een onbeduidend bestaan hebben geleid van visschers- en waterplaats, misschien ook reeds victualieplaats voor kustvaarders; die ònvermeld dus bleef bij Marco Polo (1292), Fra Odorico van Pordenone (1323), Ibn Batoeta (1345-46), Prapantja's Nāgarakěrtāgama (1365); nog tot 1403 of misschien opnieuze tegen 1403? - onderdanig aan Siam, dan met 1405 zijn opbloei krijgend onder een nog Hindoeschen Parameçwara (onafhankelijk Vorst), in 1409 stadsrechten krijgend van den Chin. Keizer; en daarop in 1414, dank zij den overgang van zijn nieuwen jongen Vorst tot den Islām onder onmiddellijken invloed der Guzeratten, zijn groote eeuw beginnend als Maleisch emporium, als Moh. handelscentrum (1414-1511) di bawah angin («beneden den Westmoeson-wind», d. w. z. beoosten Kaap Comorin). ${ }^{1}$

Wie Malaka zegt, denkt aan Singapore; of liever, om in den ouderwetschen Mal. stijl te blijven, denkt aan $\mathrm{T} \succ \mathrm{mā} s i k$, de "Zee-stad", en het "Zee-land" tevens (toestandsvorm van Mal. $t \bar{a} s i k=$ zee, ook meer; letterlijk: ge-zeed, om-zeed, door zee omgeven); in Oudjav. vorm: Toemasik.

Want àl die oude verhalen omtrent de stichting van Malaka,

1 Dit is de oorspronkelijke beteekenis voor de $15^{\mathrm{e}}-16^{\mathrm{e}}$ eeuw; zie het getuigenis uit 1554 van Arab.-Turksche zijde in Ferrand's Relations de voyages, II, 1914, p. 496, en noot 2. De Seh Rahidin, „drěwis saking nagari Ngatasangin", die, volgens de Babad Tanah Djawi p. 30, naar Java en Ampel Dĕnta (= Soerabaja) kwam, zeg in ca. 1500, en te Pamalang begraven werd, was dus uit een land beW. Kaap Comorin (verg. Brandes' Register op de B. T. Dj., Verh. Bat. Gen. LI, 1900, p. 5a). Bij het inkrimpen der Mal. zeevaart in de 16e eeuw, kromp ook dit Mal. begrip di bawah angin tot: in lij van Atjeh-hoofd (beter dan: „oostwaarts van Sumatra”, zooals Klinkert en andere Mal. Wdbb. geven). Beide beteekenissen bevat nog wel de Sadjarah Mĕlajoe van ca. 1612 in Verhaal I; zie hierachter resp. blz. 41, 42, en 47 noot 1. 
ten minste in hun volledigen vorm, geven den gang van zaken ò in 4 etappen (Java-Singapore-Muar-Malaka) òf in één etappe meer (Java-Palembang-Singapore-Muar-Malaka), waarbij dus Palembang ingeschakeld wordt tusschen Java en Singapore. Maar van Toemasik = Singapore af, zijn alle het roerend eens; àl de Port. getuigenissen; alsmede de enkele Mal. bronnen, met de oudste, de Sadjarah Malajoe in zijn $\mathrm{X}^{\mathrm{e}}$ verhaal en den aanvang van zijn $\mathrm{XI}^{\mathrm{e}}$ voorop: de moederstad van Malaka was geweest het door Favanen - bij Albuquerque: Palembangers - overweldigde Singapore; met Moewar als tusschentijdsch toevluchtsoord voor de verdreven Singapore-Maleiers, d. w. z. de afloop der ver opvaarbare sungai Muar van thans, in 't N. W. van het rijk Johore (Djohor), op resp. $\frac{3}{4}$ en $\frac{1}{4}$ van den afstand SingaporeMalaka (hemelsbreed genomen tusschen deze 2 steden) gelegen.

Het volledigst vinden we deze twee typen van ontstaan juist in de twee oudste bronnen, beide van Port. kant. Zij zijn de 2 volgende - waarbij tevens verschillende namen met meer of minder zekerheid konden herkend worden, die aan Ferrand, I, p. 433-435 en $412-417$ nog duister bleven - :

a. Oost-Fava (immers dat deel van "het eiland van Java», waar kort te voren een Vorst "Parárisá» = wellicht een verhaspeling van Oudjav. Bhra Wiçeșa ${ }^{1}$, gestorven was, en dynastieke twisten daardoor waren ontstaan, waarom vele aanzienlijken het land verlieten; en daaronder een «Paramisóra»= gewis een Parameçwara, die zijn toevlucht nam naar Singapore, waar een koning regeerde geheeten "Sangesinga» (vrage: Sanghyang Singha?) Singapore (waar P. zijn gastheer S. doodde, usurpator werd, maar nu verdreven werd door den suzerein van wijlen S., n.l. den koning van Siam) - Moewar (waar $P$. een houten vesting bouwde op een plek hoogerop die rivier, geheeten "Pago»; resp. het $\mathrm{Muwar}$ (in: $\mathrm{Paka}$, Muwar der Nāgarakěrtāgama van 1365 A. D.; Z. 14 : 2), en het Pagoh der Eng. Admiraliteitskaart No. 795 (1913), bovenstrooms van de tegenwoordige plaats Panchore,

1 Alsdan = de "Opper-Vorst". De Koning van Madjapahit, die in 1311 Caka= 1389 A. D. op den troon kwam, en in 1351 C. stierf, dus regeerde in den tijd van Malaka's opkomst als emporium, heette Bhra Hyang Wiçeșa. Zie thans de $2^{\bullet}$ editie door Dr. Krom van Brandes' Pararaton, Verh. Bat. Gen. LXIl (1920), p. 175-190. Deze naam kan in 't geheugen der Malakanen zijn gebleven. 
goed-Mal. Pantjoer; want «Pago» lag ruim 6 à 7 «legoas», dus ruim 36 à 42 K.M. stroom-op; en in welk zelfde "Pago» de in 1511 uit Malaka verdreven Sultan opnieuw ca. 1516-1520 genesteld was, tot hij in dit laatste jaar door de Portugeezen uit Malaka onder Antonio Correa teruggedreven werd naar zijn eiland Bintan, en "Pago» werd verbrand) ${ }^{1}$ - Malaka (door P. gesticht, met hulp van "Cellates» = Sëlat-zeeroovers, goed 250 jaar voor de Portugeezen in Indië kwamen, dus 1498 - ruim-250 jaar $=$ ca. 1240, op een plaats "Beitam», lees «Bertam»; immers de (soengai) Bðrtam van den aanhef in het $\mathrm{XI}^{\mathrm{e}}$ verhaal der Sadjarah Melajoe, aldus geheeten naar de palmsoort Eugeissona tristis Griff., alwaar - zegt dan nog de S. M. - een boom bleek te groeien die malaka heette, d. i. de Phyllanthus Emblica L., een Euphorbiacee; zie resp. De Clercq-Greshoff, o. c. 1909, Nos. 1313 en 2684).

Aldus de 4 etappen bij BARros in 1553; aan het slot even aangevuld uit de Sadjarah Malajoe van ca. 1612.

b. Toemapŭl (op Oost-Java; immers waar regeerde een "Bataratamurel»= Bhațāra Tumapěl!) - Palembang (waar een vorst "Parimiçura» $=$ opnieuw Parameçwara regeerde, die zijn woord brak tegenover den Vorst van Toemap̌̌l en dààrom werd aangevallen door dien "Bataratamurel" - nota bene! -, overwonnen werd door den B. T., en nu als Palembangsch roi en exil zijn toevlucht neemt naar de groote stad Singapore, zich daar weldra, met hulp van mee- en nagekomen "Palimbões» $=$ Palembangers, ats usurpator opwerpt en handhaaft, maar na 5 jaar overwonnen en verdreven wordt door den vorst van Patani, en nu opnieuw verder vlucht naar "Muar») - Singapore (zie hierboven) - Moewar (zie hierboven) - Běrtam ("Bintão») alias Malaka.

Aldus de 5 etappen der stichting van Malaka bij AlbuQUerque JR. in 1557 ; vier jaar na Barros.

Dit zijn de twee alleroudste Port. getuigenissen, beide bovendien van prima-herkomst. Immers de eerste, van den grootsten kolo-

1 Zie over deze vernieling van "Pago" in (eind Juli) 1520: Castanheda V (1 ${ }^{\circ}$ ed. 1553), cap. 35-36; en Barros III (1e ed. 1563), Lib. III, cap. 5. 
nialen geschiedschrijver dien eenige natie kan aanwijzen, BARROS, welke wel nooit in Indië is geweest, maar àl de koloniale archiefstukken te Lissabon tot zijn beschikking had gehad na zijn benoeming tot Factoor van het Oostindisch Huis in 1532. De tweede, van den begaafden Afrikaanschen bastaardzoon van den grooten Albuquerque (1461 òf '62 - † 16 Dec. 1515 op de reede van Goa), welke in zijn lange leven (1500-1581) evenmin ooit in Indië was - contra Ferrand, die (II, p. 107) onbegrijpelijkerwijs meende van wèl - , maar die dan toch al het officieele brieven-materiaal van zijn vader tot zijn beschikking heeft gehad voor den opbouw van de met recht vermaarde "Commentarios» op het leven van zijn held en vader; véél meer materiaal, dan thans uit het Rijksarchief te Lissabon is te voorschijn gekomen sedert 1884. ${ }^{1}$

Het eenige wezenlijk gewichtige daarnààst, is wat de SADJARAH MALAJOE zoo wonderlijk vertelt in twee scherp van elkaar gescheiden perioden, resp. in Verhaal $n^{\circ} 5$ en Verhaal $n^{\circ} 10$. Ook dit moet hier samengevat, naast $\mathbf{a}$ en $\mathbf{b}$ van hierboven, als volgt:

c. In VerhaAl 5 (transcriptie-ed. Shellabear 1898, p. 2627): de "Batara Madjapahit» had bij een dochter des Radja's van den berg Si-Goentang (= den «Mahameroe» $=$ den vulkaan Merapi in Minangkabau - zooals we, dank zij WESTENENK, thans met stelligheid weten ${ }^{2}-$;

1 O. a ontbreken de brieven tusschen 15 Febr. 1508 en 16 Oct. 1510, alsmede die tusschen 22 Dec, 1510 en 1 April 1512; zie dl. I der Cartas de Affonso de Albuquerque, ed. Bulhão Pato, Lisboa 1884. De laatstgenoemde lacune is juist Albuquerque's Malaka-tijd. De later verschenen 5 (of 5 ?) dln. dezer uitgave (1898, 1903, '10, '12 (?), '15(?)) bevatten geen brieven meer van A., doch andere documenten uit zijn periode. - Dat de bastaardzoon Braz, in midden 1516 herdoopt tot "Affonso", nimmer in Indië was, maar opgevoed werd bij zijn tante in Portugal, staat al deels te lezen bij Correa, Lendas, II, 1 (1860), p. 376, 457-458, en vooral 461; zie voorts het interessante boekje van den Rijksarchivaris A. Baião, Affonso d'Albuquerque (Lísboa 1913), p. 7-9, en 115.

2 Tijdschr. Bat. Gen. LVII (1916), p. 242-243, 250-251 (met noot 1), en vooral p. 252-254 Over den juisten naam Si-Goentang - vroeger meestal getranscribeerd Sigantang; soms ook Sagoentang (aldus b.v. Raffles in zijn "Abstract of the genealogy of the Rajahs of Pulo Percha", in Malayan Miscellanies, II, Bencoolen 1822, $12^{\mathrm{e}}$ Stuk, p. 3-4: „Saguntang-guntang Penjaringan", alsmede V. d. Tuuk in Tijdschr. v. N.-I., 1849, I, p. 386) kan aan bedoelde noot 1 op p. 251 worden toegevoegd, dat niet Wilkinson in 1908 het éérst dien zuiveren vorm liet drukken, maar . . alreeds èn MarSDEN in 1811 (History of Sumatra, 3rd ed., p. 339): ,the mountain Si guntangguntang", en opnieuw V. D. Tưk in Bijdr. Kon. Inst. 3, I (1866) p. 409: „op 
welke berg weer gelegen was aan den bovenloop van de "soengai Malajoe» (p. 13) = de Batang Hari!) twee zoons. De «Batara» raakt «zoek» (dood), en wordt opgevolgd door den oudsten dezer twee, die zijn macht uitbreidt over alle radja's der "Noesa-Tamara», lees: noesantara (Archipel). Nu tracht deze óók "Singapura» te onderwerpen met een groote vloot van 6 Jav. scheepṣtypen (djong; mělangbang, niet "melangbing»; kaloeloes; djongkong; tjerroetjah?, soms juister tjoeritjah?, verg. toch V. d. Tuuk, I, p. 588b; en tongkang), maar krijgt de kous op den kop.

In het voorafgegaan VERHAAL 2-3 (o.c. p. 13-24) was alreeds verteld, hoe Singapoera gesticht was geworden van Bintan uit door Sang Nila Oetama, zoon van Sang Sa-poerba ${ }^{1}$ bij de dochter van den Radja van $\mathrm{Pa}(\mathrm{ra}) \mathrm{lembang}$, Demang Lebar Daoen; welke Sang Sa-poerba (= Heere Voorzaat?), afstammeling van Alexander den Groote, miraculeus was neergedaald bij

[den] berg Siguntang." Doch dit bleef aan de aandacht ontsnappen, behalve aan die van Prof. Niemann, welke het overnam in zijne Bloemlezing uit Mal. geschriften $\left(1^{\circ}\right.$ ed. $\left.1870-71\right)$. Wilkinson, die zoo te zeggen methodisch zijn bronnen niet noemt, had zijn juisten naam wel te danken aan hen.

Maar wat beteekent Si-Goentang dan toch? In het Maleisch schijnt „goentang" als woord niet voor te komen; zie o. a. Klinkert's Zakwoordb., $2^{\text {en }} \mathrm{dr}$. 1910. Maar Roorda-Vreede's Jav. Wdb. 1901, II, p. 542a geeft bij „goentang": "goemoentang, weergalmend, doordringend van een geluid"; en daarnaast vindt men i. v. guntang II in V. d. Tuuk's Kawi-Wdb. IV, 1912, p. 652b: „angguntang, op de guntang [= de Jav. goemb $\breve{e n g}$, d. i. "een slag-muziekinstrument van een lid van bamboe, met een gat er in" (Jansz, 1876); blijkens p. 852a] spelen." Een zéér mooie Mal.-Oudjav. naam dus voor dezen werkzamen Vulkaan in het hart van Minangkabau! Dit herkennen der beteekenis van den naam Si (Mal.) + Goentang (Oudjav.) = (zeg:) "De Slag-schalmei", impliceert: dat dan ook de boekit Si-Goentang precies hetzelfde is als de (goenoeng) Maha-meroe, en niet b.v. een lagere, andere, top op de flanken van den Minangkabauschen nog steeds werkzamen Mĕrapi.

Van de Sadjarah Malajoe gebruikte ik de ed. in Latijnsche karakters door W. G. Shellabear, Singapore 1898 - verg. over deze en over de voorafgegane editie van 1896 in Arab. karakters, Dr. van Ronkel in Tijdschr. Bat. Gen. XLIV, 1901, p. 358-359 en 371-372 -, onder vergelijking met den $2^{\text {en }} \mathrm{druk}$ in 2 deeltjes, Singapore 1910 . Voorts als standaard-vertaling de belangrijke oude door Dr. J. Leyden, teruggaand tot 1805, uitgegeven na zijn dood (28 Aug. 1811) door Raffles, Londen 1821, als "Malay Annals"; hier en daar onder vergelijking met de Fransche vertaling (naar Abdoellah Moensji's Mal. tekst met Arab. karakters uit ca. 1840, de standaard-tekstuitgave) door A. Marre, Vaucresson 1900; soms met de gedeeltelijke Fransche van L. M. Devic (1878).

1 Shellabear transcribeert: Sang Si-Pĕrba; wel zeker onjuist. 
dien "boekit Si-Goentang Maha-meroe» (p. 15), zijn mooien naam ontvangen had van een $\mathrm{Bața}(\mathrm{l}$ a ?) - welke niet enkel plots was opgerezen uit het bekschuim van een "lëmboe» (versta: $\mathrm{karbau}$; à bon entendeur etc.), maar die zelfs nog Sanskrit kon spreken (o Adityawarman-zaliger!) - ${ }^{1}$ en nu, na deze treffende mythe-gebeurtenissen in het hartje van oudMenang-karbau,... naar Palembang was gekomen (versta: afgezakt was langs die "soengai, Malajoe namanja" van daareven), er als Radja was opgetreden, en zijn schoonvader (Demang Lebar Daoen) tot mangkoeboemi had aangesteld (p. 17); alwaar diezelfde (Hindoe-schim) B a ț a ( $1 \mathrm{a}$ ?) een torenhoog badhuis had gebouwd voor den Vorst, dat pantja-persada heette (o oud-Mal. bijara's, alias vihära's, te Moeara Takoes, Tandjoeng Medan, Pertibi, Aek Biara, aan resp. de bovenloopen der Kampar-, Rěkan-, en Panei-rivieren!). Edoch Sang Sa-Poerba, na familierelaties te hebben aangeknoopt met den "radja Tjina» - op verzoek van dezen laatsten natuurlijk! (p. 18) -, en na een politieke plezierreis naar Tandjoeng Poera te hebben gemaakt - welk (diamantrijk) Z. W. Borneo nota bene "Zuid» (sělatan, p. 19), in plaats van Oost, van Palembang heet te liggen! -, alwaar de batara Madjapahit hem een bezoek had gebracht, en zijn schoonzoon was geworden (zie boven!), was daarna wel verder getogen naar Bintan, begeleid door zijn zoon Nila Oetama en zijnen schoonvader Lebar Daoen, maar had, na zijn zoon te hebben uitgehuwlijkt aan de dochter der op Bintan regeerende

1 Over de 2 perioden in ouderwetsche Sanskrit-karakters bij Leyden in 1821 afgedrukt op p. 24 en 100, in resp. Verhaal 2 en 11, zal Prof. van Ronkel. hierachter een aanvullende studie geven. Leyden (p. 24, 27, 28, 44; 100) transscribeerde: B at'h, en vertaalde het op p. 24 met „(Bard)", wat juist ook op die plaats in den tekst uitstekend past; Marre $(1900 ;$ p. $20,22,23,32 ; 68)$ transscribeerde: Batha; maar Shellabear's transcriptie $(1898$, p. $15,17,24 ; 47)\left(1910 \mathrm{~d}^{\circ}\right.$.) heeft 7 maal: Batala. Beide kan goed zijn, blijkens Dr. Hoesein's noot op p. 249 in Westenenk's studie van 1916: òf Skr. bhațța = geleerde bard óok Oudjav., blijkens V. d. Tuuk IV, p. 994a -, òf bațala = een bijvorm van Bhațāra, Godheid, vandaar ook Oppervorst. Dit Mal. Baţala (nog niet te vinden bij Klinkert, 1910) komt toch juist zoo voor in het Tagalog (b a thala); en zou merkwaardig aansluiten hij het Toempangsche (d.i. oud-Toemapĕlsche) èn... oud-Minangkabausche Bhar $\bar{l} \mathrm{la}$, jong Jav. barhala, brahala, hedendaagsch-Mal. be rhala, dat wel 30 jaar lang een raadsel is geweest; totdat Prof. Kern het in een (posthuum) stukje „Barhala” (Bijdr. Kon. Inst. 73, 1917, p. 495-496; thans Verspr. Geschr. IX, 1920, p. 315-316) eindelijk thuis heeft gebracht als : een (waarschijnlijk) Bihar'sche, d. i. Magadha'sche Boeddhisten-term (o Kěrtanagara- èn Adityawarman-zaliger in de $13^{\circ}$ Çaka-eeuw!). 
Koningin ( $\mathrm{P}$ r rmais oeri) Iskandar Sjah (p. 20), alléén zijn reis voortgezet naar de monding van de Kwantan-rivier (koeala Koeantan, p. 21), was die rivier opgevaren (moedik), en was dus... (weer terug )gekomen in M enangkabau (p. 21), waar zijn (Hindoesche, alias "Alexander»-) makota (p. 21) opzien baarde. Hier nu werd hij Radja, en oer-vader der Radja's van Pagar-roejoeng (p. 22). - Voorts in Verhaal 3:

De stichting der stad Termāsik, hernaamd Singapoera (vanwege een singa, die zich daar aan 't strand vertoond had!), van Bintan uit, volbrengt dan Sang Nila Oetama zònder zijn vader ${ }^{1}$, maar mèt zijn (Hindoe-schaduw) $\mathrm{Bața}(\mathrm{l} \mathrm{a}$ ?) bovengenoemd; welke zijnen Heer bij diens inhuldiging aldaar den naam en titel verleent van Çrī Triboewana (Heer over 3 Landen; vrage: Palembang, Tandjoengpoera, en Singapore??). Grootvader Lebar Daoen wordt tevens Radja van Bintan. (p. 22-24).

$\mathrm{Na}$ deze legendaire historie van Verhaal $2-3$ en 5 , waarvan Verhaal 2 reeds opmerkelijk doorzichtig is in den tegenwoordigen tijd, en opmerkelijk gewichtig van geschiedkundige substantie tevens, gaat de Sadjarah Malajoe, ten vervolge op Verhaal 5, waarin een éerste doch vruchtelooze aanval van Fava op ToemasikSingapoera zeer duidelijk wordt geschetst, éérst vertellen in Verhaal $7-9^{2} \ldots$ de stichting, opkomst en bloei van PaseiSamoedra; eene stichting, die, zooals wij ook thans stellig weten, dank zij Marco Polo's gegeven uit 1292, aangevuld en bevestigd door MoQUETTE' en HOESEIN DJAJADININGRAT's onderzoekingen der gespaard gebleven Pasei'sche Vorstengraven, in het slot der $13^{\text {e }}$ eeuw valt; als Moh. centrum wel te verstaan. ${ }^{3}$

1 Curieus is, dat Couto in zijn Decada IV (afgesloten 1597, afgedrukt 1602) eene "weduwe van Singapore, genaamd Milãotania" in dit verband als schoonmoeder vermeldt; zie bij Ferrand, I, p. 443 met noot 2. Natuurlijk een tekstverwarring met Nila Oetama, wiens schoonmoeder de Vorstin-Weduwe van Bintan was, die hem juist trachtte tegen te houden van dat gaan stichten van Singapore. Het bewijst, hoe namen en verhalen uit den cyclus der Sadjarah Mĕlajoe (geschreven tusschen 1612 en 1614, zie ons $I I^{\mathrm{e}}$ Gedeelte) reeds tot Couto in Goa waren doorgedrongen vóór 1597, zij het dan corrupt.

2 Verhaal 4 en Verhaal 6 vallen buiten het kader van den geregelden gang der vertelling; het zijn beide roman-achtige inschuifsels. Van middenin Verhaal 16 - waar juist een der 2 (of meer?) hss., die Leyden bij de vertaling dienden, eindigds; zie bij hem op p. 193 - wordt dit episodische al meer en meer in 't oog vallend. Men zou zoo zeggen: er is vóortgebreid aan de door anderen opgeze1te kous! Verg. ook voorgaande noot over een tekst vóór 1597 ; en Eredia's spreken in 1599 van „annaes Malaios" (zie blz. 24 noot).

s Verg. J. P. Moquette's „De eerste Vorsten van Samoedra-Pasè” in Rap- 
En dàn volgt het voor ons hoogst gewichtige VERHAAL 10, aldus (ed.-Shellabear, 1898):

Eerst een geheel symbolisch geworden en òndoorzichtig relaas van een groote school zwaardvisschen (todak; p. 41), die op Singapore aanvallen, en het geweldig in het nauw brengen, maar die door de list van een knaap toch ten slotte moesten afdeinzen. De toenmalige Vorst, "Padoeka Çrī Mahāradja», laat echt̄er dezen slimmen knaap uit dynastie-angst dooden. Van toen af lag er bloedschuld "atas něgerri Singapoera» (p. 41). Coming events etc.! Wie die todak's echter waren, blijkt niet. Javanen zeker niet, noch Siameezen; dàt zou wel aangestipt zijn. Veeleer schepen van echte Orang Laoet, alias zwaard-visschen. Maar van waar? ${ }^{1}$

$\mathrm{Nu}$ echter komt de katastrofe. Een even onrechtvaardige

porten Oudh. Dienst N.-I. 1913, Bat. 1914, p. 1-12, met 9 platen; en zijn en Dr. Hoesein Djajadiningrat's art. "Oudheden (Mohammedaansche)", in Encycl. v. N.-I., $2^{\text {on }}$ druk, III (1919), p. 202a: Soeltan Malik aṣ-Salih, d.i. de legendaire stichter uit Verhaal 7 der Sadj. Mĕl. Mĕrah Siloe, $\dagger$ midden 1297.

1 Het bovenstaande over die todak's = vermoedelijk Orang Laoet (dus: die Zeeroover-stammen om en bij Sing a pore èn elders) welke in de Port. bronnen der $16^{\mathrm{e}}$ eeuw Cellates of Ceilates, d.w. z. "Sìlat-lieden," heeten, was al eenige dagen neergeschreven, toen mijn oog viel op de volgende zinnen in Th. Braddell's vertaling van een deel der Hikajat Abdoellan (1e Mal. ed. Singapore 1849) in het Journal Indian Arch. VI (1852), p. 585-604 - weer hervertaald door $\mathrm{P}$ [ijnappel] in Bijdr. Kon. Inst., 1, II (1854), p. 431-461, maar hier en daar verkort; en verg. het daarvan geheel onafhankelijke, zeer mooie en degelijke opstel van G. N[iemann], "Geschiedenis van Abdallah", in Tijdschr. N.-I. 1854, I, p. 73-101, 297-313, met Aanhangsel p. 314-315 -:

"At the mouth of the Singapore river there were many large rocks, and the passage among them is crooked like a snake wounded by beating [inderdaad is de benedenloop der Soengei Singapoera, van Kim Seng Bridge tot aan zee, vrij sterk gekronkeld]. A mong the stones there is one with a sharp point, like the projecting point of a sword fish 「Niemann l.c. p. 93 heeft hier "toedak"; de transcriptie van Abdoellah's Hikajat in Lat. karakters door Shellabear, Singapore 1907-8, 2 deeltjes, heeft in I, p. 143: todak]. T'his rock is called by the Orang laut "the sword fish's head rock" [di-namakan oleh Orang-orang Laoet batoe kapala todak], they believe that it is haunted, and at that place they are accustomed to make all their solemn agreements, as they hold it in reverence. They also pay great respect to the rock, decorating it with flags [di-boeboehnja pandji-pandji]", etc. (p. 591). Deze rots aan den mond der Singapore rivier, nog in ca. 1819 de Heilige Rots der Orang Laoet, was wel die waarop zich de Oudjav. inscriptie bevond welke zoo dadelijk ter sprake komt (blz. 35 vlg.; en zie blz. 54, noot).

Over de Orang Laoet van tegenwoordig, zie het art. (blijkbaar door Prof. A. L. van Hasselt) in Encycl. v. N.-I. $1^{\text {en }}$ druk, III [1902], of 2e ed. III (1919); historisch is dit echter geheel onvoldoende, en een Sp. "Lutaos" bestaat niet. Dl. 77 . 
terechtstelling door den zoon en opvolger van gezegden Mahāradja, Radja Iskandar Sjah, gelast, is oorzaak dat de thesorier des Konings (běndahari), genaamd Sang Radjoena Tapa, heimelijk inroept de hulp van den "Batara Madjapahit (p. 22); alzoo - dus ten tweeden male - komt nu een groote vloot van 4 Jav. scheepstypen (djong, kaloeloes, pelang, djongkong) en een groot leger van 200.000 "rajat Djawa». Finis Singapurae! Radja Iskandar Sjah vlucht naar Muar (p. 42), en dan in begin van Verhaal 11 naar de soengai Bĕrtam, en sticht hier Malaka (p. 43). De Javanen gaan weer scheep naar Madjapahit (p. 42). Maar de bëndahari en zijn vrouw worden door God veranderd in 2 steenen, die (in den trant van Lot's vrouw, Gen. 19:26) tot op dezen dag (ca. 1612) te zien zijn in de parit Singapoera (p. 42). Vrage slechts: wààr lag die gracht der kota $\mathrm{S}$. van weleer ? ${ }^{1}$

Dit slotdeel van 't Verhaal 10 is duidelijk: we hebben hier gewis de overweldiging van Toemasik-Singapore door Madjapahit nà ca. 1260 Çaka $=1338$ A. D. - toen immers, blijkens de Pararaton, de (in 1253 Caka opgetreden) Rijksbestierder Gadjahmada een gelofte deed omdat "Gorong, Ceram, Tandjoengpoera, Ha r o e, P a hang, Dompo [Oost-Soembawa], Bali, Soenda, $\mathrm{Palembang}$, èn... Toemasik» nog niet onderworpen waren ${ }^{2}$

1 Raffles schreef wel dd. Singapore, 31 Jan. 1819 aan Marsden: "The lines of the old city [of Singapore], and of its defences, are still to be traced" (Memoir, London 1830, p. 376); maar daardoor weet men niet verder, dan dat er een parit was. - In ons $I I$ e Gedeelte wordt dit echter opgehelderd.

2 Ed. Brandes, 1896, p. 120; zijn gelofte was, dat hij pas weer „palapa zou eten", zoodra die 10 landen onderworpen waren; wat echter „palapa" mag zijn, wordt ook niet duidelijk in V. d. Tuuk's Kawi-Wdb. IV (1912), p. 248a. De tekst luidt (Brandes, p. 28): „Sira Gajah madâpatih amangkubhûmi tan ayun amuktia palapa, sira Gajah mada: "Lamun huwus kalah nuṣantara $[=$ de Maleische Archipel] isun amukti palapa, lamun kalah ring Gurun, ring Seran, Tañjung Pura, ring Haru, ring Pahang, 1)ompo, ring Bali, Suṇ̦ạ, Palembang, Tumasik, samana isun amukti palapan" In de bijbehoorende verklarende aanteekeningen op dezen tekst, l. c. p. 125-126, aarzelde Brandes nog of "Tumasik" hier een "wisselnaam was voor Samoedra = Pasei op Sumatra's Oostkust, ò wel = Singapoera; en verg. aldaar nog p. 130-131. -

Zie thans de $2^{\circ}$ ed. Brandes-Krom, Verh. Bat. Gen. LXII, 1920, p. 36 (tekst), 141 (vertaling), 147-149 (verklaring). Ook vindt men hier op p. 128, noot 5 drie verklaringen voor dat amukti palapa: 1. van zijn apanage genieten (alap; Poerbatjaraka); 2. zijn ontslag nemen (lapa; V. d. T.); 3. rust nemen (phalapa, V. d. T.) Als $4^{\text {e }}$ geeft Dr. H. Kraemer bij zijn Proefschrift (1921) „Een Jav. primbon uit de $16^{\circ}$ eeuw", de stelling VI: non-actief worden (lapa=leeg). 
一, en vóór 1287 Çaka $=1365$ A. D., toen àl die eilanden en staten in Oost en West van den noesantara (Archipel) wel degelijk de suzereiniteit erkenden van Madjapahit onder Vorst Hajam Woeroek, blijkens het lofdicht Nāgarakěrtāgama; terwijl de geweldige Gadjahmada juist het jaar te voren was gestorven. Dus zeg: in ca. 1360 A. D. was Toemasik-Singapore, hetwelk zoo veelbeteekenend daar achteraan op het program van Gadjahmada's imperiale staatkunde staat - de laatste loodjes wegen het zwaarst! - dan eindelijk door Madjapahit toch onderworpen.

Kenden we nu maar het geheim der groote Oudjavaansche inscriptie van Singapore, "welke echter in [circa] 1839 door de domme baldadigheid van Gouverneur S. G. BonHAM werd "opgeblazen» en voor immer vernield», zooals ik in 1909 mijn verontwaardiging daarover al eens uitte. ${ }^{1} \mathrm{Zij}$ lag aan den mond der Singapore-rivier, op den Z.O.- dus rechteroever, daar waar vroeger "Artillery Point" was (d. w. z. waar de batterij aan het Z.O. uiteinde der monding stond opgesteld, voor eventueele verdediging en saluut-schoten), en waar ongeveer thans het "Master Attendant's Office» (d. i. Havenmeesters-kantoor) staat, dichtbij het "General Post Office» dat iedereen weet die in Singapore is geweest. ${ }^{2} \mathrm{Zij}$ lag

1 Notulen Bat. Gen. 1909, p. 96. Door een drukfout, waarvoor ik niet verantwoordelijk ben, staat daar: BonHouR. Over deze vernieling, zie hier verderop.

2 Voor de tegenwoordige situatie gebruik ik de uitvoerige "Map of Singapore", Singapore, Fraser \& Neave, 1908, schaal 5 inch: 1 mile (d.i. dus $1: 12.672)$. De breede verbindingsweg, die thans van het General Post Office licht stijgend voert naar het oude Commercial Square (in 1822 door Raffles en Farquhar aangelegd, sinds 1858 officieel hernaamd: Raffles Place; waar de groote toko's van Singapore zijn) heet nog altijd: Battery Road.

Voor de situatie in 1836, zie den uitvoerigen plattegrond ${ }_{n}$ Map of the town and environs of Singapore, drawn by J. B. Tassin, from an actual survey by G. D. Coleman”, terwijl onderaan staat: „J. B. Tassin's lith ${ }^{\circ}$ Press. Calcutta 1836", en de schaal (14,9 cM.) = 8 furlongs (d. i. dus $1: 10,800)$, maar zònder Noordpijl, afgedrukt geheel vooraan J. H. Moor's "Notices of the Indian Archipelago, Part I", Singapore 1837. Deze plattegrond werd, op ca. $\frac{1}{4}$ verkleind, en zònder het jaartal, gereproduceerd tegenover p. 288 in dl. I van T. J. Newbold's ${ }_{n}$ Political and statistical account of the British settlements in the Straits of Malacca", London 1839; en daarnaar weer geclicheerd tegenover p. 320 in Ch. B. Buckley's "An anecdotal history of old times in Singapore", Singapore 1902, 2 dln. (met doorloopende pagineering; over 1819-1867), met het niet geheel correcte onderschrift "Map, date about 1835 to 1838 ", blijkbaar omdat aan Buckley het origineel in Moor was ontgaan. Men ziet op dezen plattegrond aan de Z.O. punt der Singapore-monding alleen een trapezium-achtig bouwwerk aangegeven, met het bijschrift: Battery. Dezelfde ingenieur Coleman vernielde de inscriptie in ca. 1839! 
dus aan den Z.O. oever der koewala, vlak aan zee; "a large stone at the point of the river, the one face of which has been sloped [= schuingemaakt] and smoothed, and upon which several lines of engraven characters are still visible», zooals Capt. P. J. BEGBIE haar als "the principal curiosity of Singapore» - o Groote Goden! - met ware zorg beschreef in zijn boek The Malayan Peninsula, (Madras) 1834, p. 355 ; er bij voegend, dat Raffles die van 6 Febr. 1819-9 Juni 1823 (her)stichter en Gouverneur van Singapore was geweest, resideerend te Bengkoelen; met Majoor W. Farquhar als Resident ter plaatse - reeds alle moeite had gedaan om een ontcijfering der inscriptie te verkrijgen. Blijkens het facsimile dat Dr. W. BLAND er van maakte, zoo goed als hij kon, in eind 1836 of voorjaar,'37, en aan den Oriëntalist J. PrinseP te Calcutta inzond, die in 1837 er een eigenhandige lithographie van publiceerde op $\frac{1}{12}$ der ware grootte in het Augustus-nummer van het Journ. As. Soc. Bengal, dl. VI, p. 680, was deze inscriptie een 2,10 M. breed, 1,50 M. hoog, en telde 50 (à 52 ?) deels zéér verweerde en onleesbaar geworden regels; ${ }^{1}$ de heele steen, noteerde Bland voor Prinsep, was ca. 10 voet hoog, 2 à 5 voet "thick» en 9 à 10 voet *in length", welke maten van het voorvlak: ca. 10 Eng. voet $=$ ca. $3 \times 3$ M., zeer wel dus plaats lieten voor de boven uitgerekende afmetingen der inscriptie: $2,10 \times 1,50$ M.; de 2 à 5 voet "thick» wordt verhelderd door Bland's vermelding dat de "stone or rock of coarse red sandstone», was "somewhat wedge-shaped» (1. c. p. 681). Voor dat «red sandstone» moet men alleen juister lezen: roode

1 Gewaarschuwd moet hier worden tegen de reproductie van deze Plaat XXXVII bij p. 680 in dl. VI (1837) van 't Journal As. Soc. of Bengal, in dl. I (1886), p. 219 van de Miscellaneous Papers relating to Indo China, door Dr. Rost uitgegeven in Trübner's Serie; want die staat daar weer verkleind $(14,1 \times 10,5 \mathrm{cM}$., in plaats der origineele $17,7 \times 12,8 \mathrm{cM}$.), zònder dat dit er bij gezegd wordt; het tevens gereproduceerde ${ }_{n}$ Scale, one twelfth of the original" is hier dus bedrieglijk. Het voordeel in dezen herdruk (o. c. p. 219-230) is echter, dat men er alles wat in 1837 en 1848 over de Singapore-inscriptie

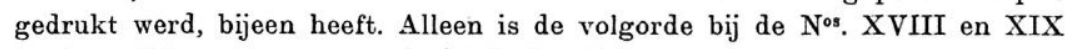
(p. 221-223) averechtsch; en had bij No. XIX (ten rechte: XVIII) moeten gezegd zijn, dat dit was een "Extract of a letter from Hon. Col. Butrerworth, Governor of the Straits Settlements", want $n u$ makt het den verwarrenden indruk of het óók van J. Low kon zijn (zie nader blz. 50).

Prinsep's plaat van 1837 geeft 40 regels, maar boven regel 1 staat: about 12 lines effaced above line 1.", dus het eerste $5^{\circ}$ deel der heele inscriptie, wel met den naam van den Vorst en het jaartal, was geheel uitgesleten. Bland's notitie (met inleidend woord van Prinsep) zegt: „about fifty lines". 
lateriet; het typische graniet-verweeringsgesteente van Singapure toch, zooals ieder weet die het "rosse» Singapore zich weer voor oogen roept. Dus: een ter plaatse aangetroffen lateriet-rotsblok aan zee; géén van overzee aangevoerd rotsblok, van b. v. andesiet uit Java. Prinsep achtte het schrift-type "Pálí (p. 680); terwijl Bland, aan het slot van zijn zorgvuldige notitie voor Prìnsep, na gezegd te hebben dat hij (Bland) het aanzag voor "ancient Ceylonese, or Pálí», de opmerking maakte: "I may as-well mention that tradition among the Malays, points to Telinga [= Kalingga] and Ceylon as its origin, which may be seen more at length in LEYDEn's Malayan Annals.» (p. 682); zonder dat hij dit laatste echter precizeerde.

Heeft hier BLAND, dokter a/b H. M. S. Wolf (welk schip, blijkens Buckley's interessant boek, Singapore 1902, p. 277, van 22 Maart 1836-29 Mei 1837, als oorlogsschoener tegen Mal. zeeroovers, Singapore tot station had gehad) misschien gezinspeeld op iets, dat aan den ouderen beschrijver der inscriptie, Begbie in $1834-$ wiens boek "The Malayan Peninsula" natuurlijk aan boord van den schoener ("sloop») zich bevond -, was ontsnapt? BEGBIE toch had, héél verdienstelijk, Leyden's vertaling der Sadjarah Malajoe (Malay Annals, 1821) er op nagegaan, of die soms aanduidingen bevatte over het bestaan der Singapore-inscriptie, en was tot dit resultaat gekomen (o. c. p. 35 9, slot (het verhaal van den gedooden Toen Djana Chatib: Leyden, p. 82-83), misschien; in Verhaal 10, slot (l.c. p. 87 ; over den oud-Singapoerschen Lot en zijn vrouw; zie boven, blz. 34) óók misschien; maar in Verhaal 6, midden en slot (p. 58-59, en 62-63) waarschijnlijk werd gezinspeeld op dat oude inschrift.

Want in dit laatste verhaal, de heldendaden beschrijvend van den athleet Badang "at Salwang», van "the country of Sayang», die tot voorvechter (hoeloe-balang) werd aangesteld van den Vorst van Singapore, "Sri Rama Vicrama» (p. 53-56), ${ }^{1}$ en een wedkamp hier aanging met den hof-athleet van "the raja of Kling", wordt verteld hoe hij een loodzwaren steen voor 's Vorsten hof te S. oppakte en wegwierp "ka-soengai Koewala Singapoera", en dat dit de steen is, die tot heden [1612] zich bevindt "di hoedjoeng.

${ }^{1}$ Shellabear in zijn transcriptie (1898, p. 27 en 28) schrijft terecht resp.: Saluang; Sayong; en Sri Rana Wira Krama; in 1910 (I, p. 40) transcribeert hij dit laatste: Sĕri Rana Wira Kĕrma. Dat Saluang (Sĕloewang) en Sayong (Sajoeng) thuishooren in den bovenloop der rivier van Djohor, zal in ons II $\mathrm{e}$ Gedeelte uitvoerig blijken, evenals op de daaraan toegevoegde Schetskaart. 
Tandjoeng Singapoera itoe» (Shellabear, 1898, p. 29); ${ }^{1}$ ja, in een tweeden beraamden wedkamp, nu met den hof-athleet van den "radja Perlak», kwam het niet eens tot de proef, zóózeer besefte die Perlakker zijn minderheid tegenover Badang; maar toen dan Badang stierf, en begraven was geworden "at the point of the streights of Singhapura» (Leyden, p. 62), toen zond de Radja van Kling op het hooren van dit doodsbericht, blijkbaar uit diepen eerbied voor den ex-Hercules, "two stone pillars, to be raised over his grave as a monument, and these are the pillars which are still at the point of the bay" (p. 63). ${ }^{2} \mathrm{Nu}$ werd door Begbie dit een en ander kennelijk misverstaan; hij meende toch dat hier sprake was van een en denzelfden steen: dien eenen, dien Badang wegwierp, èn het grafmonument bij dien steen. Want hij schreef, onder erkenning dat de aanduidingen uit Verhaal 9 en 10 zeer zwak waren, het volgende over de z.i. afdoende aanwijzing in VerHAaL 6:

"Now, the first two instances are totally destitute of presumptive evidence; this last is, on the contrary, full of it: At the mouth of the river there is a large rock, which is concealed at high water, and on which a post was erected four or five years ago $[=$ ca. 1829] by, I believe, Captain Jackson of the Bengal Artillery, to warn boats of the danger; this is the rock fabled to have been hurled by Badang: He is said to have been buried at the point of the straits of Singhapura, the scene of this wonderful exploit; and there, the very spot where this record is to be still seen, the Rajah of Kling, who had been so serious a loser by it, ordered his monument to be erected.» (o. c. p. 358).

Door de hier onvoldoend-duidelijke vertaling van Leyden, die

1 Leyden's vertaling (p. 58-59) zegt desgelijks : „.... and [Badang] then threw it [scil. the stone] out into the mouth of the river, and that is the rock which is at this day visible at the point of Singhapura or Tanjong Singhapura."

"Hier heeft echter de Mal. tekst (Shellabear, p. 32; en verg. daarmee conform Marre's vertaling, 1900, p. 44-45): „Hata brapa lamanja, Badang poen mati-lah; maka di-tanamkan orang di Boeroe [d.i. te Tandjoeng Boeroe, de uiterste Z.W. punt van 't vasteland van het Schiereiland]. Shahadan tĕlah kadĕngaran ka-bĕnoewa Kĕling Badang soedah mati, maka di-kirim oleh radja bĕnoewa Kĕling nisjan batoe $[=$ de 2 grafpaaltjes aan hoofd-en voeteneinde van een. Moh. graf $]$; itoe-lah nisjannja jang ada sĕkarang ini $[=\mathbf{c a}$. 1612 A. D.] di Boeroe itoe." 
het woord [Tandjoeng] Boeroe van den Mal. tekst niet genoemd had, maar enkel sprak van "the point of the streights of Singhapura», is Begbie er in geloopen. ${ }^{1}$ De reuzensteen, dien Badang slingerde, lag volgens Verhaal 6 aan den mond der Singaporerivier; het graf van Badang, door den Vorst van Keling opgericht naar Moh. trant(!), lag echter bij $T$. Boeroe (alias tegenwoordig: T. Boeloes), aan de uiterste Z.punt van 't vasteland, nabij den W.-ingang dus der Sělat Těberrau of Old Strait, die benoorden het eiland Singapore omloopt, en welke kaap niet minder dan 39 K.M. recht West hemelsbreed verwijderd is ${ }^{2}$ van den mond der Soengai Singapoera; - terwijl juist aan dien mond de beschreven steen tot ca. 1840 lag, evenals bók het bij vloed onderloopend rotsblok dat Begbie nader bespreekt; zonder dat overigens uit zijn woorden blijkt of deze twee steenblokken nu wel identiek waren. Het tegendeel zou waar kunnen zijn; Begbie's steen uit ca. 1834 was alleen bij eb boven water, en kan misschien de reuzensteen zijn in Verhaal 6 als Badang's slingersteen bedoeld; van het in 1836 of voorjaar '37 zoo zorgvuldig door Bland in situ beschreven wig-vormig rotsblok met (Oudjavaansche) inscriptie (uit ca. 1360 A. D.?) blijkt duidelijk, dat deze op de Z.O.lijke landtong lag, vlak bij zee. Indien dus deze beschreven steen in het Badang-verhaal der Sadjarah Malajoe, $\mathrm{n}^{\circ} 6$, bedoeld mocht zijn, dan is het verband met den «Radja

1 Th. Braddell, die in het Journal Indian Archip. V-VI (Singapore, 1851-52) een "Abstract of the Sijara Malayu... with Notes" publiceerde in 9 vervolg. stukken, gebaseerd èn op Leyden's vertaling èn op den (vermoedelijk in 1840) te Singapore door de zorg van Abdoellah Moensji gedrukten Mal. tekst, heett bij het 6th Annal (V, p. 249) reeds deze zeer goede Noot 7 geplaatst: „The champion was buried at Tanjong Buru, the extreme south west point of the Peninsula, opposite Point Macalister, or closer, Tanjong Gool in Singapore Island [resp. het uiterste W. en W. Z. W. punt van 't eiland], but I cannot say if any traces remain of the monument erected by the Indian King." De oude T. Buru der $16 \mathrm{e}-19^{\mathrm{e}}$ eeuw, is in ca. 1860 definitief verhaspeld tot Bulus; op de "Chart of Singapore Strait" uit 1836 bij Moor (o.c. 1837, p. 269) leest men nog: "Tanjong Buru or Pecai" (waarin dat „Pecai" thans heet: T. Piai), weer verkleind herhaald bij Newbold (1839), I, p. 266. Kan „Pecai” of „Piai" soms ten rechte zijn Mal. pehak = kant, zijde? •

"Verg. de "Sketch of the Island [of Singapore], about 1828", genomen naar de kaart in Rafles' Memoir (1830), p. 377, vóóraan Buckley's dl. II (Singapore 1902). Men ziet daar de namen der 3 kapen, in de vorige noot vermeld. Thans is de naam van T. Buru officieel: Bulus (de Kale Kaap); zie het voortreffelijke, flink met kaartjes geïllustreerde schoolboek van C. M. Phillips, „The Malay Peninsula", $2^{\text {d }}$ ed. Bristol 1906, op het kaartje tegenover p. 103, alwaar men ook iets ten O. van „T. Bulus" ziet „T. Piai”. 
van Kelling» er toch nog alleen met de haren bij te sleepen.

De•aanduidingen uit Verhaal 9 en 10 vond Begbie-zelf reeds nietszeggend. Inderdaad, Verhaal 9 vertelt aan 't slot slechts even over een (Moh.) Paseier, te Singapore gedood wegens vermoeden van ontuchtigheid jegens een vrouw des Vorsten, van wiens bloed een vakman toen een poffer (bikang) maakte, en dien poffer met de pan toedekte, al hetwelk vervolgens "měndjadi batoe; datang sěkarang poen ada di Singapoera» (Shellabear, p. 41); hier wordt dus een poffer-achtige groote steen ergens aan het strand van Singapore bedoeld, die aanleiding gaf tot een volkslegende. De twee groote steenen door Verhaal 10 aan het slot befabeld als de tot steenen geworden Majordomus van Singapore en zijn vrouw (uit ca. 1360 A. D.; zie hiervóór blz. 34-3j) lagen bij de oude gracht (parit) der reeds vóór 1600 vrijwel uitgestorven stad; houden dus niet het minste aannemelijk verband met den beschreven steen aan den mond der rivier. Aldus is, bij nader kritisch beschouwen van Verhaal 6, dat Begbie in 1834 "full» achtte van "presumptive evidence» - en waarbij latere schrijvers zich zijn gaan aansluiten - die evidentie ineengeschrompeld tot de bloote mogelijkheid, dat wezenlijk met Badang's Hercules-steen ter "koewala Singapoera» uit ca. 1612, te voren gelegen hebbend vóór des Vorsten pěndopo ("sa-boewah batoe di hadapan baleirong itoe terrlaloe běsar», Shellabear p. 29), de beschreven groote steen, aan de monding aanwezig tot ca. 1840, bedoeld is.

Is dit nu alles, wat de in (zoogenaamd) 1612 aangevangen Sadjarah Malajoe min of meer verhaalt over dien beschreven steen, welke in 1819 - zooals we door het interessante $13^{\text {e }}$ hoofdstuk "Dari hal Tengkoe Long» van de in 1849 te Singapore in 't Maleisch voor het eerst verschenen HiKaJat ABdoELlaH weten (waarover op blz. 61-62 nader) - door toedoen van Goeverneur RAFFLES en Resident FARQUHAR werd herontdekt?

Neen! Er is, liefst in VerhaAl 1, één gedeelte dat tot voor kort aan allen - opeén na - was ontsnapt. Aan BEGBIE (1834); aan BLAND (1837; hoewel deze misschien er op gedoeld kan hebben, maar het dan toch volstrekt niet heeft uitgesproken, zie blz. 37); aan LaIDlay (1848 ${ }^{1}$, zie hierna, blz. 59 ; die het eerste licht deed opgaan over 3 van de 4 naar Calcutta in het Museum

1 Men mag zich verbazen, dat Newbold in zijn daareven (blz. 35 noot 2) reeds vermeld uitvoerig boek van 1839 over de toenmalige Straits Settlements, volstrekt zwijgt omtrent den beschreven steen van Singapore. 
der Asiatic Society of Bengal overgebrachte en aldus geredde brokstukken met schrift); aan den Arabisch-Tamilsch-Maleischen halfbloed - juister op zijn Spaansch: cuarterón - ABDOELLAH BIN ABDOELKADIR, bijgenaamd MoEnsji (den Taalleeraar), die in 1839 à 1840 den eersten Mal. druk der Sadjarah Malajoe nog wel bezorgd had (1849; zie blz. 61 noot 2); aan BRAUDELL (1851; die in zijne hiervóór, blz. 39 noot 1, reeds aangestipte Abstracts with Notes van de Sadj. Mal. het eerst, naast Leyden's vertaling, óók de Mal. tekstuitgave ernstig en doorloopend vergeleken had); aan den Malaicus Niemann (1854; die in zijn mooi opstel over Abdoellah's Hikajat van 1849, in het T. v. N. I. $16^{\text {en }}$ jrg., I, p. 96, alléén aanhaalt de 3 ook door Begbie in 1834 bedoelde plaatsen uit Leyden's Malay Annals); aan CRAWFURD zelfs (1856; in zijn Descriptive dictionary of the Indian islands; zie hierachter blz. 62-63); ja, zelfs aan BRANDES (1896; die in zijn aanteekeningen op de uitgave van de Pararaton wèl op p. 125-126 verwijst naar Verhaal 3; op p. 130-131 naar de Verhalen 2-6, en 10; op p. 132 aanroert Verhaal 14; en dit laatste uitvoerig daarna bespreekt op p. 159-162; maar juist zwijgt over Verhaal 1). En tòch is Verhaal 1 zoo véélzeggend!

Want in dit VerhaAL 1 (Shellabear, 1898, p. 7-12) wordt zéér duidelijk gesproken over een beschreven steen met "Hindostan»-taal, gelegen te $\mathrm{T} \breve{m} \mathrm{a} \mathrm{sik}$; in het volgende verrassende verband:

$\mathrm{Na}$ een eerste inleiding naar den geijkten hoogdravenden trant (Vorst Alexander van "Makedonia»; dan diverse Armenische(?) en schijnbaar Perzische Vorstennamen eindigend op as en oes en ah en oet) komen we op meer begaanbaren, tasthaar-historischen, grond met Radja Soelan (p. 7) - versta natuurlijk een Chola-vorst van Zuid-Dekhan! 一, zetelend te "Amdān-nagara»; òf een gefantaseerde, òr een onherkenbaar-gefigureerde naam. ${ }^{1}$ Gróót was deze, de machtigste èn van alle " radja $^{2}$ Hindi dan Sindi», èn ook van "sěgala radja ${ }^{2}$ jang di bawah angin» (p. 7); d. i. hier wel van alle Vorsten beO. kaap Comorin, dus van wat wij "Achter-Indië» noemen, of nòg ruimer de Franschen: l'Extrême-Orient. 's Vorsten dochter

1 Braddell in zijn Notes (Journ. Ind. Arch. V, 1851, p. 132) giste hierin: Hamadan-nagara, dus West-Perzië. 
had 3 zoons: 1. Radja Iran, regeerend in Hindi-land(!); 2. Radja Soerān, de Groote, opvolger zijns grootvaders in "Amdān-nagara»; 3 . een vorst in Turkestan.

Radja Șoerān, de zéér Groote, wil ook China onderwerpen; het éénige land, waarover hij nog niet gebood. Dies trok hij op met een mateloos heir; en nadert de «stad» Gangga-nagara; d. i. niet "Ganges-land», maar: Water-land of Zee-land. ${ }^{1}$ We zijn immers al een eind op het Maleische Schiereiland; want de (Moh.) Vorst, geheeten Radja Gangga Sjah Djohan(!), resideerde in deze "stad" op een hoogen heuvel, waarvan de kota thans is .... di darat Dinding (Mal. dinding $=$ borstwering; op z'n later $16^{\mathrm{e}}$ eeuwsch Portugeesch-Maleisch : baloewarti), «al iets voorbij» Perak (p. 8); inderdaad bij het Settlement "the Dindings», middenin het tegenwoordig vorstendom Perak, aan de kust. ${ }^{2}$ Radja Soeran neemt het fort, doodt den Sjah, huwt diens schoone zuster - alles volgens het bekende recept -, en trekt verder; d. w. z. Z.Z.O.waarts. Van een "Malaka» wordt natuurlijk niet gerept; het bestaat nog niet, ondanks CoRREA-FERRAND! Maar wèl komt R. S. nu in het land Ganggājoe; hetwelk op de volgende hóógst opmerkelijke wijze wordt beschreven: vroeger was dit een groot land (of: rijk), met eene kota van zwarte steen, en thans is er nòg die kota «di hoeloe soengai Djohor»; in het Siameesch heette het oorspronkelijk "Klang Kio», wat beteekent "schat van edelsteen", maar omdat men (scil. de Maleier) dit niet kon uitspreken, "werd het Ganggājoe»; hier heerschte Radja Tjoelan, die de grootste vorst was van "sěgala radja" di bawah angin» (p. 8), d. w. z. hier: van alle Indonesische vorsten! ${ }^{3}$

1 Nog in 't Jongjav. is in de dichtertaal ganggå = banjoe; zie Roorda-Vreede, 1901, II, p. 641a. Voor Oudjav. gangga en gangga $=$ er (Mal. ajër), zie V. d. Tuuk, IV, 1912, p. 825b-826a. - Braddell, 1. c. p. 133, gaf hier in Note 51 het voor de hand liggende "Ganges".

${ }^{2}$ De hier voor de situatie gewichtige tekstwoorden zijn: „... maka Radja Șoerān poen sampai-lah sa-boewah něgěri, Gangga-nagara namanja.... Adapoen nĕgĕri itoe di atas boekit, ...: ada sěkarang kotanja di darat Dinding, ka-sana Perak sĕdikit" (p. 7-8). - Het reeds in 1600 antieke centrum van Dinding, Bruas (Bĕroewas), in Verhaal 26 der S. M. genoemd, lag op 4 $27^{\circ}$; de mond der Perak-rivier in Zuid-Perak (Lower Perak) ligt op $4^{\circ} \mathrm{N} . \mathrm{Br}$.

3 De weder voor de situatie hier zeer gewichtige tekstwoorden zijn :,$\ldots$ Radja Șoerān... datang-lah kapada nĕgĕri Ganggājoe. Sjahadan đĕhoeloe kalanja 
Want wààr zijn we hier? We zijn in 't land Ganggājoe $=$ Gangga ajoe (Oudjav.) $=$ Fraai-water $=$ weder $\ldots$. het geheimzinnige Woera-wari $=$ "Klaar (van) water ${ }^{1}$, waarvan de Vorst in 928 Çaka $=1006$ A. D., volgens eigen getuigenis van Mahāradja Er-langga oftewel «Oppervorst Water-slurper» - let wel! op een der zijden van de tweetalige inscriptie (Skr. en Ojav.), thans in 't Indian Museum te Calcutta, een geweldige ramp over "geheel Fava» had gebracht ${ }^{2} ;=$ óók weer het Worawārī (Varavārī), dat

nĕgĕri itoe nĕgĕri bësar, kotanja daripada batoe hitam, datang sĕkarang lagi ada kotanja itoe di hoeloe soengai Djohor" (p. 8). Shellabear transcribeert: Suran en Ganggayu; Marre (1900, p. 10): Sourân, en Ganggâyou; Leyden (1821, p. 10) had hier afwijkend: Glang Kiu, terwijl hij den (gewaanden) Siameeschen naam gaf als: Khlang Kbiaw. Dat goochelen met dien zgn. "Siameeschen" oorspronkelijken naam, is evenzeer een praatje voor den vaak der Maleische lezers, als straks - zie den hoofdtekst op blz. 44, en de noot aldaar het promoveeren van het Mal. pangkal = hoeloe, tot een "Siameesch" woord pangkal = rivier! De oorspronkelijk-Maleische naam was dus: Ganggājoe; in quasi-Siameesch: $\mathrm{K}(\mathrm{h})$ lang Kio.

1 Voor Oudjav. wura = suddha, høning (louter, zuiver, helder; óók: wit), en voor wāri $=$ wari $=$ warih (water), zie resp. V. d. Tuuk's Kawi-Wdb. III(1901), p. 470b; p. 467b, en 472. Voor Ojav. wari $=$ Njav. worawari $=$ Hibiscus Rosa-sinensis L., zie volgende noot. - Voor de wijze van samenstelling verg. Nila-kaṇța= Blauw-hals = Çiwa, en de vele andere Oudjav. eigennamen, met vóórop nila (V. d Tuuk, I, p. 546a); eveneens den Palembangschen (Děmang) Lebar Da oen = Brééd-van-blad, op blz. 30; Mal. lehar tangan $=$ ruw van hand; e.a.

- Zie de studie van Prof. Kern uit 1913 (Bijdr. Kon. Inst. dl. 67), thans herdrukt in zijn Verspreide Geschr. VII (1917), p. 102-114. Tekst op p. 101, regel $5-6:, \ldots$ kāla ning pral ay a ring y aw ad wīpa, irikang çakakāla 928 mra? - - haji wurawari an wijil sańke l warām, ek a rṇ a w a rūpa nikang sayawadwīpa rikāng kāla": vertaling op p. 107: „... ten tijde van den grooten vloed van rampen (of: des ondergangs; of: der débâcle; zie Kern's noot 6 l.c.) op het eiland Java in 't Çakajaar 928 - - vorst Wurawari toen hij uitkwam van Luarām; geheel Java zag er te dien tijde uit als ééne zee."

Bij dat „Wurawari" teekende Prof. Kern (noot 7) aan: „W uraw ari, Njav. worawari; of het hier een persoon, dan wel een plaatsnaam is, blijkt niet." Jongjav. worawari is de zeer geliefde Hibiscus Rosa-sinensis L., Oudjav. wari, djapakusuma, Balin. poetjoek, Mal. boenga raja („hoofd-bloem”), vulgair k‘mbang sapatoe, de ook door de Chineezen vanouds hooggeschatte fu-yung (zie Groeneveldt's Notes, 1876 , p. 62 , voor 519 A. D.), met zijn òf bloedroode òf witte bloemen; zie De Clereq-Greshoff o. c. (1909), $\mathrm{n}^{\circ}$. 1796. De witte, thans zeldzamer, variëteit is gewis antiek (Ojav. wari putih, wari pinge, zie bij V. d. Tuuk), evenzeer als de roode (wari bang, w. rakta); aansluitend bij de soort Hibiscus mutabilis L., waarvan de witte bloemen 's avonds rose worden, ib. $\mathrm{n}^{\circ} .1795$.

Wat Lwarām, Luarām, mag beteekenen, zal verderop ook blijken. Maar dat in dat ekarṇawa $=$ eka-Arṇawa $=$ één Zee, een historischpolitieke toespeling ligt op de onheilbrengende Zee-macht in 928 Çaka van het rijk Woera-wari = Klaar-water, staat voor mij vast. 
de Hof-codex ("Palatine Law») van Siam uit ca. 1360 A. D. noemde als toenmaals (of daaromtrent) onderworpen aan Siam, samen met Oedjoeng Tanah (de Z.O.spits van 't Maleisch Schiereiland, bij kaap Romania), Malaka, en Malajoe (= of Palembang alleen, òf Djambi alleen; òf, en veeleer, beide te zamen), zooals we hiervóór (blz. 22-23), dank zij GERINI, vernamen! En die kota van dat land Woerawari of Worawari, alias Ganggājoe, lag aan den bovenloop der soengai Djohor; zooals nader in ons $I I^{\circ}$ Gedeelte zal worden geprecizeerd.

De verrassingen zijn echter allerminst hiermee gedaan. Het verhaal vervolgt:

Radja Tjoelan - die hier plotseling wordt omgetooverd tot een (zoogenaamd!) Siameesch vorst, want zijn troepen heeten "rajat Siam» (p. 8) - verneemt de nadering van Radja Soeran -- welke hier even plots zich ontpopt als een heusch Klingsch (=Koromandelsche Chola-) vorst, want zijn troepen, o Tanjore-inscriptie van 1030 A. D.!, heeten ineens "rajat K $\mathrm{K}$ ling》(ib.) -, en trekt den invaller tegemoet tot een rivier, die in "Siam-taal Pangkal (heet); de zin van "pangkal» is rivier(!), vandaar heet die rivier bij de lui (nu nog) soengai Pangkal, (ib.). Met zulke praatjes voor den vaak van zijn Maleische lezers, ommantelt de schrijver het eenigszins pijnlijke feit, dat die Maleische vorst van Ganggājoe, optrekkend tegen den Klingschen vorst - herinnering aan RAJENDRACOLA I, 1012-1042 A. D. ? - en dezen opwachtend bij de bronnen of het "begin» (Mal. pangkal) van zijn eigen soengai Djohor, dus aan den Zuidvoet van den ca. $1000 \mathrm{M}$. hoogen top "Chimundong» (zie onze Schetskaart der Djohor-rivier, en verg. Phillips, o. c., 1906, p. 103), het gaat afleggen! ${ }^{1}$

1 Hier heeft Leyden's vertaling (1821, p. 11) in plaats van de „rivier" Pangkal: "the river [which] still retains the name of Panggil», omdat "Raja Chulan" bij zijn afwachten van 't Klingaleesche heir bij die rivier... "said, in the Siamese language, "call them""!

De Mal. goochel-zinnen bij Shellabear (1898, p. 8) zijn: „.. maka Radja Tjoelan poen bĕrangkat mĕngloewari [ = optrekken tegen] Radja Șoerān; . . datang. lah pada soewatoe soengai; maka kĕlihatan-lah rajat Radja Șoerān sĕpĕrti hoetan roepanja. Maka kata Siam: "Pangkal»; artinja "pangkal» itoe soengai. Maka di-namaï orang soengai itoe, soengai Pangkal." Marre (1900, p. 11) schrijft: Tchoulon; èn (volgens Abdoellah's tekst van ca. 1840): Lankâyou, d. i. dus Langka + ajoe (verg. het nog altijd niet behoorlijk gelocaliseerde Lĕngkasoeka, „ergens" op het Mal. Schiereiland), anders ook genoend 
Er volgt een reuzengevecht, waarbij het eng toegaat (dit in Ned. jongedames-stijl). Radja Soeran doodt hoogsteigenhandig Radja Tjoelan [den Maleier], huwt (alweer) des gedooden Vorsten overschoone dochter, en trekt met frissche kracht verder, ,nadat zijne "rajat Kelling poen masok ka-dalam Kota Ganggājoe itoe» (p. 9). Wààr trekt Z. M. heen?... "těroes ka-Těmāsik»! Dat de Klingsche Vorst daartoe de Sĕlat Těberrau = de "Glagahstraat» of Old Strait of Singapore, moest oversteken, om van Azië's vasteland op het Singapore-eiland te komen, laat de auteur na te vermelden; evenals hij te voren nagelaten had mede te deelen, dat Radja Soeran natuurlijk per schip van "Amdan-nagara» (=?, in Zuid-Voorindië) naar «Gangga-nagara» = Dinding was gekomen, maar dit integendeel als één- en- al landtocht voorstelt, waarbij de grond s'trilde als een (aard-)beving» (p. 7), en zulke fraaiigheden meer.

Zoo komt Radja Soeran dan te Temāsik; waarvan niets hier verder gezegd wordt, of er een radja was, of een kota, of zoo iets. Maar dat hij hier aan zee, aan de heusche tāsik staat, dàt blijkt overduidelijk uit den tekst. Want... de $R$ adja $T$ jina, die vernomen had dat $R$. S. op weg was tegen hem, en daarbij dat deze "sěkarang soedah sampai ka-T.̌māsik» (p. 9) stond, volgt den raad van zijn leepen Opper-Mandarijn (perrdana - of pradana mantrri), en zendt een pěrahoe (hier, en elders vaak in den tekst: pi-lau, op z'n Chineesch) met allerlei bedroglading (roestige "naalden" — vrage: Chin. kompas-naalden? -, tandeloos oud scheepsvolk, enz.), en beveelt dit gecamoufleerde schip "běrlajar ka-Těmasik» (p. 10)! R. S., die (naar het schijnt) kalm aan Singapore's zeestrand was blijven wachten, schrikt, zoodra hij dit oude zoodje uit het "běnoewa Tjina» op die "perahoe» (nu niet meer pilau!) verneemt;... zóó ver dus was dat Chinaland verwijderd? Dàn liever "kěmbali», alias huis-toe!

Edoch, hij krijgt een heerschersgril. Hij beveelt (oud

"Ganggâyou", in plaats van het „,K(h)lang Kio" der andere transeıipties; in zijn Index op p. 272 werd dit „Lankâyou" echter vergeten, zooals er meer dan een plaats- en persoonsnaam over het hoofd werd gezien. Devic (1878, p. 15-16) gaf: naar Dulaurier's tekst van 1856: Tchoulin, en Ganggayou. 
recept: Sic volo, sic iubeo!) een glazen kist te maken aan gouden ketting; en daalt daarmee af, om de Wonderen Gods te leeren kennen, in de zee (gewoonweg: la o et). Hij landt in de "boemi Dikā» (wel= Java), waar een "kaoem Barsam» (p. 10; lees: Berrsāma?) woont, half van kafir's, half van Islām'mers, vindt er een Vorst, huwt (alwéér; $n^{\circ}$. 3) diens beeldschoone dochter - verg. hier het (symbolische) huwelijk van een $\mathcal{F} a v$. Oppervorst met de (Njahi) Làrå Kidoel; Babad Tanah Djawi, ed. Meinsma 1874, p. 139 (Senapati), 258 (Sultan Ágoeng)! —; maar ontrukt zich eindelijk aan deze min-geneugten, bestijgt den voor hem beschikbaren gevleugelden wonderhengst (koeda sěmbrani djantan; p. 12), vliegt over de zee en komt weer te land op zijn punt van uitgang (ka-těpi laoet itoe; dùs: te Těmāsik). ${ }^{1}$

Toen sprak de Vorst tot zijne geleerden en handwerks-

1 Hier heeft Leyden (1821, p. 15) resp. „Zeya” en „Barsam"; doch “Zeya» kan drukfout zijn voor "Zega" (verg. er op p. 7 de drukfout: Amdan Nayara). Shellabear's 2c druk (1910, I, p. 14) heeft echter: Rika, niet Dika. - Het zéér opmerkelijke van deze reis met een Kling'schen onderzeeër uit Tĕmāsik naar een legendair land van Overzee, en terugreis per lucht-hengst Sěmbrani (alias Pegasus; Soend. Samparani; de Sambarani van het Balin.-Middenjav. gedicht Rangga Lawe, zie V. d. Tuuk's Kawi-Wdb. III, 1901, p. 357b) is, dat in de Jav. wajang-litteratuur een sterk hieraan herinnerende reis per djaran sĕmbrani voorkomt van Dronă, alias Koembåjånå - zijnde een zoon van Bagawan Barat-mådjå of Barat-mĕdjă, uit het land Atas-Angin = WestVoorindië; een verre heugenis blijkbaar aan den toovermachtigen Wijze Mpoe Bharāịa of Mpoe Bradah uit Erlangga's tijd! - naar Java, waarbij eene widadari "Wiloetåmâ" de lucht-merrie was; zie toch Cohen Stuart's noot 30 (p. XVII) in zijn Inleiding op dl. I van zijn Bråtå-Joedå (1860). Nu is Wiloetåmå = Tilottama hier aequivalent met... Sang Nila Oetama, den Vorst van 't eiland Bintan, en stichter van... T'émāsik (naar Verhaal 3 der Sadjarah Malajoe)! Er is m.i. dan ook weinig twijfel, of dit Mal. Dikā=Jav. dika $($ ook dika) $=$ Skr. adhika (Roorda.Vreede, 1901, II, p. 351b) = het "puik"Land, is: Java; vooral ook daar adhika een epitheton ornans o. a. was van Wilwatikta = Madjapahit (Nāgarakṛıāgama ed. Kern-Krom, 1919, Z. 12:4, Tiktawilwādhika; p. 49 en 257).

Vanzelf ligt dan de conjectuur voor de hand, of men niet het "a people named Barsam" (Leyden, 1821, p. 15), en "suatu kaum, Barsam nama-nya" (Shellabear, 1898, p. 10), eenvoudig mag lezen als Mal. Běrsama = „Gemengd" (n.l. van Kafir's en Islamieten na 1102 A. D.; Arab. inscriptie van Leran)? De koeda Sĕmbrani, het Gevleugeld Lucht-ros, is hier vermoedelijk het dichterlijkkinderlijk geziene Staatsie-schip van een Oostersch vorst, daarna mythe geworden; de glazen kist aan gouden ketting is daarentegen een kennelijk modern-Maleisch bedenksel uit ca. 1612. 
lieden: "Ik wensch dat gij allen een monument ("alamat tanda) mij maakt, dat Ik inging tot deze zee,.... opdat het verstaan en vernomen worde door al Mijne kinderen en kindskinderen in lengte van tijd». Aldus geschiedt. Allen halen "soewatoe batoe, maka di-soeratnja oleh mareka [= die Klingsche onderdanen] dengan bahasa Hindoestan» (p. 12). Vervolgens nam Radja Soeran veel goud en zilver en edelgesteenten, "en [dit alles] werd door hem neergelegd samen met dien beschreven steen" (maka di-tarohnja sama-sama batoe soerat itoe). Ende Hij sprak:

"Aan het einde der eeuw [òf: des tijds?] weldra, zal er een Koning zijn uit Mijn geslachte, dewelke zal krijgen dezen schat: ende die Koning zal terneerwerpen alle landen van hier Benedenwinds.» ${ }^{1}$

Zóó sprak Hij. En Radja Soerān ging toen "terug(sic) naar Kling-land» (kembali ka-běnoewa Keling), alwaar hij een groote vesting bouwde, die hij noemde "Bidjanagara», welke stad nu [1612] nog bestaat in Kling-land (sěkarang poen ada lagi něgerri itoe di běnoewa Kěling). Dus: Vijayanagara, de hoofdstad van het befaamde laatste groote Hindoe-rijk in Centraal-Dekhan (Bellary; Madras), ca. 1335_-1646 A. D.; welke hoofdstad echter reeds in 1565 werd verwoest. Vrage: is "Amdan-nagara» niet een wisselnaam voor "Bidja-nagara»? ${ }^{2}$

Maar is het niet verbazingzekkend, dat dit VerHaAL I der Sadjarah Malajoe niet reeds sinds een eeuw, toen Raffles in 1821 de vertaling van Leyden posthuum het licht liet zien, de aandacht van alle oudheidliefhebbers te Singapore getrokken heeft,

1 De tekst is (Shellabear, p. 12): „Pada achir zaman kĕlak ada sa-orang radja daripada anak-tjoetjoe-koe, ija-lah jang bĕroleh harta ini; dan radja itoe-lah jang mĕnaloekkan sěgala něgri jang di bawah angin ini." Dit is dus weer hier, in geheel Indonesië. Over dit Mal. „benedenwinds", in lij = in luwte, Eng. leeward, makte Crawfurd reeds in 1820 de mooie opmerking (History Ind. Archip. II, p. 376), dat men daarmee in verband moest brengen het Jav. barat $=$ athe general term for wind (en speciaal: Westenwind, Westmoeson-wind), terwijl dit in 't Mal. Westenwind-alléén is (en vardaar ook weer: West). Dus Mal. angin is hier = Jav.-Mal. barat; "the wind" (Cruwfurd).

2 Leyden (p. 19) had: Bijnagar; Devic (1878, p. 27) zoowaar: Souran-BidjiNagara; Shellabear (1898, p. 12): Bij-nagara; Marre (1900, p. 16): Bidji-Nagârâ; Shellabear in 1910 ten slotte goed: Bija-nagara (I, p. 17). 
toen ze nog met hun neus konden liggen op den eigen beschreven steen te Temāsik - of "Tamsak» zooals Leyden in Verhaal 1; "Tamasak» echter, gelijk hij in Verhaal 3 transcribeerde ${ }^{1}-=$ Singa poera (zó́ Verhaal 3)? Edoch, noch Raffles (1819-23); noch FARQUHAR; noch Farquhar's opvolger als Resident te Singapore, de begaafde JoHn CRAWFURD (1823-26); noch de onderzoekende Capt. P. J. BEGBIE in zijn waardevol boek van 1834, zooals wij hiervóór zagen; noch - vóór het veel te laat was! - de oudheidliefhebber en Malaicus Capt. (later Colonel) JAMFS Low, die den steen in 1838 (of 39, of uiterlijk 1840) voor zijn oogen met hartzeer heeft zien opblazen; - hebben er ook maar aan gedacht te gissen, toen het nog tijd was, dat daar aan den mond der Singapore-rivier de steenen oorkonde lag, in Verhaal 1 der Malay Annals van Leyden zoo aartsduidelijk met den vinger der Maleische romantiek aangewezen! Dat RAFFLeS met zijn genialen geest en vurige belangstelling, bezorger (editor) der eigen Malay-Annals-uitgave nog wel, ontdekker reeds in 1818 van de inscripties in Minangkabau, daar niet aan heeft gedacht, is kortweg verbijsterend. En hoe men, tot heden toe zoo te zeggen, langs Verhaal 1 als gewaande "legende» is voorbij blijven loopen, is in de korte opsomming hiervóór (blz. 40-41) van BEGBIE tot BRANDES gebleken.

Slechts één man heeft het, wel gezien; toen.... het allang te laat was. Dat was Low bovengenoemd. En zóó zorgvuldig heeft hij zijn herkennen dan nog weggestopt, dat niemand van zijn tijdgenooten - in de eerste plaats de Malaicus BRADDELL, meermalen reeds vermeld - het heeft opgemerkt ${ }^{2}$; totdat het eindelijk in 1894 uit zijn schuilhoek te voorschijn werd gehaald door N. B. Dennys, den compilator van den indertijd verdienstelijken, nu zeer verouderden "Descriptive dictionary of British Malaya", welke een hoofdje opnam "Inscription, Indian * (p. 163-164), en daar yoor de verdwenen Singapore-inscriptie, vroeger "on a sandstone rock at the entrance of Singapore river, on the spot now occupied by the Harbour Master's Offices»,

\footnotetext{
1 En wel: 4 maal eerst „Tamsak" (p. 13-14), en daarna evenzeer 4 maal „Tamasak" (p. 42-44); met op p. 44 als slot: , and thus Sang Nila Utama settled the country of Tamasak, named it Singhapura, and reigned over it," etc.

2 Zie toch Noot 57 over "Tamsak or Tamasak" van Braddell in zijn „Abstract of the Sijara Malayu", 1st. Annal, op p. 133 in hetzelfde Journal Indian Archip. V (1851), dus 4 jaar na Low. En zie vooral ook zijn humoristische, doch inderdaad kortzichtige Noot 63 (p. 134) over den inhoud-zelven der inscriptie!
} 
verwees naar.... Low's alinea (meer is het niet) in Journal Indian Archip., I (1847), $3^{\text {e }}$ of Sept.-afl.; p. 89.

Want Low, en Low-alléén (naar zijn beste weten en mijn ernstigste zoeken), heeft in dat jaar, midden in een opstel van 18 blz. (p. 83-100), nota bene, "Notes on the geological features of Singapore and etc.», deze zinnen vol juiste gedachten over de toen al circa 7 à 10 jaar vernielde inscriptie doen afdrukken:

"That the slightly reddish crystalline sandstone [of Singapore] is very durable may be inferred from the fact that there was a rock of it, bearing an ancient inscription, extant on the narrow point on the left of the entrance [bij 't binnenvaren dus; kiri op z'n Maleisch] to the Singapore river, but which was demolished several [sic] years ago in clearing the spot for some building [lees: het bouwen van den zeekade-muur; zie blz. 54 noot]. The inscription, fragments of which I possess [minstens 3 fragmenten, die in het jaar daarna te Calcutta in 't Museum (nu Indian Museum) terecht kwamen; zie blz. 55] was only' legible in a few places, the character appertaining to the Peninsula of India, and probably [sic] it may be that described in the Malayan annals in these terms [nota bene:] *Rájá Súran of Amdan Nagárá after conquering the state of Johore with his Kling troops (Kling is the term applied to the people of Coromandel) proceeded to Tamsak. When he returned to his country of Kling or Bejaneegar, he left a stone monument of his victories [minder juist!] on which was an inscription in the language of Hindoostan.» Tam Sak is also called Singhápúrá (Leyden's Translation, Annal 1st and 2d [lees voor $2 \mathrm{~d}: 3 \mathrm{rd}])$. This was about A. D. 1201. Singapura, observes Mr. Crawfurd [n.l. in zijn History of the Indian Archipelago, Edinburgh 1820, II, p. 373; waar Crawfurd zelf weer aanhaalt uit Marsden's History of Sumatra, 3rd ed.; London 1811, p. 327] was first settled in A. D. 1160 by Sri Súra Bawáná.» 1

Dan gaat Low weer op "the sandstone» over!

Maar dit was de plaats waarop Low zelf - zooals uit het

1 A an 't slot van deze ,Notes on the geological features of Singapore and some of the islands adjacent", staat: "Province Wellesley, 1st July, 1847" (p. 100). De drukfouten "extent" en "proceed" zijn hier verbeterd; Low's nootje "Leyden's Translation, Annal 1st and 2d." werd ingevoegd.

Dl. 77. 
verband der data blijkt: in voorjaar 1848 - "alluded», toen hij, na 't ontvangen uit Calcutta te Wellesley (tegenover Penang) der Februari-aflevering van Part I, vol. XVII (1848) van 't Journal As. Soc. of Bengal - waarin was opgenomen op p. 154155 een stukje over de "Inscription at Singapore» van den Gouverneur der Straits, resideerend te Singapore, Colonel W. J. Butterworth ${ }^{1}$, die de droeve kwestie der vernieling van den beschreven steen het eerst aan de groote klok hing -, eindelijk en ten laatste uit zijn zwijgers-tent werd gelokt, en opbiechtte het volgende, aan 't slot van een in Mei (?) door hem geschreven opstel, "An account of several Inscriptions found in Province Wellesley on the Peninsula of Malacca», opgenomen in de Juliaflevering van dat Journal:

"While about to close these notes the Journal of the Society for February last has reached me [te Penang, of op den O. overwal]. In this number I observe (Page 154) [BUtTERWORTH's stuk] that inquiries have been made regarding the inscription at Singapore described in the Journal, vol. VI. [1837; door PRINSEP en BLAND, zie hiervóór blz. 36-37] p. 680, and that the Hon'ble Colonel Butterworth, C. B. [Low's chef in de Straits; immers Governor van Singapore + Penang + Malacca sinds Aug. 1843; opvolger van den verniel-Gouverneur SAM. G. BONHAM, Governor van Maart 1837-Jan. 1843] supposes that I may have some portions of the stone on which it was engraved. [Low begon ambtelijk zich dus minder pleizierig te voelen! $\mathrm{Nu}$ volgt de Biecht:]

I was an unwilling and pained witness to the demolition of that memorial of long past ages, my petition to have it spared being met by the reply that it was in the way of some

1 Dit stukje, met bovengezegden titel (een titel, welke te Calcutta werd gegeven door de Redactie van het Journal) is een excerpt uit een schrijven van Gouv. Butterworth aan den $2^{\text {en }}$ Secretaris der As. Soc. of Bengal, den epigraaf J. W. 'Laidus. In de Proceedings (Maart-afl.; p. 243) werd het genotuleerd als: ,From the Hon. Col. Butterworth, to Mr. Laidlay, promising to send the fragments of the Singapore inscription to the Museum of the Asiatic Society." Maar het excerpt werd vooraf gegaan door een inleiding van een anoniemen "I", welke niemand anders als dezelfde LAIDLAY kan zijn geweest (zie nader blz. 56 noot 3, en blz. 60 noot 1). In den Index van dit Part I (met de 6 afl. Jan.-Juni 1848) staat het op naam van Gouv. Butrriworth, hetgeen alleen juist is voor het slot. - De zending van het fragment had daarop plaats per geleideschrijven dd. Singapore, 18 Febr. 1848. 
projected bungalow [op het terrein der oude "Battery", in ca. 1840 vergroot en hernaamd Fort Fullerton ${ }^{1}$, aan het uiteinde van de Z.O.punt der Singapore-monding]. On the explosion taking place, I crossed the river from my office [staande aan den N.W. of linkeroever der rivier, aan 't uiteinde ook; alwaar het Police Office stond, waar Low - blijkens Buckley, 1902, I, p. 366 - inderdaad Chef toen was] and selected such fragments [3 stuks minstens; zie blz. 49, en hierna] as had letters on them. The Hon. the Governor, Mr. Bonham, sent to ask me to preserve a piece for him, and this is the portion [het $4^{\mathrm{e}}$, veel grootere, stuk, thans nog in de kelders van 't Indian Museum te Calcutta (zie onder), nog nimmer afgebeeld, noch ontcijferd; en waarop dus de hoop mag rusten, dat dit toch nog het Singapoersch-Oudjavaansche geheim ons zal kunnen ontsluieren door 't onderzoek van een deskundige!] alluded to by Col. Butterworth [zie onder].

${ }^{1}$ Het is mij niet gelukt, door het boek van Buckley uit te maken wanneer Fort Fullerton - sinds 1590 totaal verdwenen - zijn naam heeft gekregen ter eere der nagedachtenis van den Eersten "Governor" der "Straits Settlements", maar (tot 1837) resideerend te Penang, R. Fullerton (Aug. 1826-Maart 1829; gestorven 1831; opvolger te Sing. van „Resident" John Crawfurd). Het was nà 1836, want de op blz. 35 noot 2 vermelde plattegrond van dat jaar vertoont alleen de legende „Battery"; ook Begbie (Capt. Madras Artillery) in zijn in 1834 te Madras verschenen boek weet niets van een "Fort Fullerton" en beschrijft de situatie der "river of Singapore" als volgt: „The point, or tongue of land, which forms the extremity of the right bank, trends [ = buigt om] to the eastward, and thus shuts out the view of the entrance from seaward. On this point are the artillery barracks, and house of the artillery officer, with a few pieces of ordnance [= stukken geschut]" (p. 351), terwijl hij dan op p. 355 den nog ongerepten beschreven steen gaat bespreken "at the point of the river", zoodat in zijn tijd de Batterij met de militaire woningen niet het minste nadeel had toegebracht aan de insrriptie (zie trouwens ook zijn harenkaartje bij p. 350). Ook Newbold (Lieut. Madras Light Infantry) in zijn te Londen in 1839 gedrukt, maar roor de beschrijving van Singapore in of vóór 1837 afgesloten boek „Political and Statistical Account etc." - zie toch dl. I, p. 271 noot - weet nog niets van een „Fort Fullerton”. Maar het was zeker vóór Juni 1811, toen de inscriptie-vernieler, ingenieur G. D. Coreman, naar Europa vertrok (Buckley, p. 227); en zoo vertoont de reproductie van een plattegrond van Singapore uit 1846 (in: One hundred years of Singapore, London 1921, II, p. 513) inderdaad: Fort Fullerton op dat uiteinde. In 1859 werd „Fort Fullerton" aanzienlijk vergroot (Buckley, p. 675); doch van 1865-73 ontmanteld (One hundred years of S., I, p. 379; alwaar ook blijkt, dat Gouv. Fullerton begonnen was de bovenvermelde „Battery" te doen zetten, en dat het Fort pas in 1890 geheel door overbouwing verdween; het havenlicht op dat uiteinde kreeg later toch weer den naam "Fullerton"). 
As the fragments were verybulky I had them, at considerable cost, gradually chiselled by a Chinese into the shape of slabs. But they are still ponderous. It happens however that the smaller fragments only contain the most legible (if the term is even here really applicable) parts of the inscription, the rest being nearly quite obliterated, and I have therefore selected them to be presented to the Society [of Bengal]. It seems to me that this Singapore inscription (to which I have alluded in a paper presently to appear in the Journal of the Eastern Archipelago [ik spatieer hier weer]) may probably date from an early century of our era, and... etc.» (o.c. XVII, 1848, Juli-aflevering; Part II, p. 65-66; de slotzin mist thans waarde).

Zóó kwamen de 3 fragment-«slabs» van Low te Calcutta in Juni(?) 1848; uit Penang verzonden onder geleide van gezegd *Account» van zijn hand, dat dadelijk afgedrukt werd ${ }^{1}$, en met daarin aan 't slot eene verwijzing naar een Singapoersch tijdschrift, naar welke niemand meer heeft omgekeken vóór Dennys ${ }^{2}$ ! Zij kwamen slechts korten tijd later te Calcutta aan, dan het véél grooter fragment hetwelk de Gouverneur der Straits, Col. W. J. ButTerworTH, dd. 18 Febr. 1848, rechtstreeks uit Singapore had gezonden op verzoek van den $2^{\text {en }}$ Secr. A. S. B., J. W. LAIDLAY; hierachter nader genoemd; hem beloofd in een brief van Jan.(?), waarin het volgende stond, dat Low te Penang had wakker gepord:

„Col[onel] B[utterworth] observes: -

"The only remaining portion of the stone you [=Laidlay] mention, except what Col. Low may have [de por in de richting van Penang!], I found lying [n.l. Butterworth

- bij zijn ambtsaanvaarding, Aug. 1843] in the verandah of - the Treasury at Singapore [gevestigd in het in 1827 ge-

1 Zie toch de notuleering in de Proceedings ook van Juli 1848, in J. A. S. B. XVII (1848), Part II, p. 122: „From Colonel Low, communicating four essays and papers: -1 . An account of inscriptions from the Malayan peninsula. 2... etc." Deze studie beslaat er p. 62-66. Onmiddelijk daarop volgt dan (p. 66-72) dé studie van Laidlax, met Plaat III naar de 3 Singapore-fragmenten van Low, welke hierachter (blz. 55-60) uitvoerig behandeld wordt.

2 In den gezamenlijken herdruk dezer artikelen over de Singapore-inscriptie (en andere in de Provincie Wellesley) door Dr. Rost in de Miscellaneous Papers relating to Indo-China, I (1886), is onderaan p. 226 géén ophelderende verwijzing toegevoegd naar het Journ. Ind. Arch., vol. I, p. 89. 
bouwde Court House, nu nog bestaande, op den linkeroever der rivier; iets meer inwaarts dan het straks genoemde Police Office aan den mond, alwaar Majoor Low tot Aug. 1843 als Superintendent of Police had gezeteld, en door den nieuwen Gouverneur in Sept. reeds werd vervangen ${ }^{1}$ ], where it was used as a seat by the Sepoys of the guard and persons in waiting to transact business. I lost no time in sending it to my house [d. i. Government House, van 1819-1859 gevestigd op de zgn. Government Hill, waar sedert 1859 Fort Canning kwam te staan; aan elk bezoeker van Singapore welbekend], but, alas! not before the jnscription was nearly erased. Such as the fragment was then however, i.c. in 1843, it is now; for I have preserved the stone with much care, and shall have much pleasure in sending it for your museum, having failed in establishing one, as I hoped to have done, in Singapore [sic! het "Raffles Library and Museum» werd pas in 1887 geopend]. I am happy in thus far meeting your wishes, and in assuring you that I shall always be ready to forward the views of the Asiatic Society [of Bengal].» (o. c. XVII, 1848, Febr-aflevering; Part I, p. 154-155).,

Wil men gelooven, dat Low kookte toen hij dit briefje van zijn chef (èn ambtelijken verdringer) gedrukt zag? We mogen ButTERWORTH er dankbaar voor zijn, dat hij Low uit zijn tent lokte en liet opbiechten! Anders was het verniel-geheim in den Singapore'schen doofpot geraakt. En toch biechtte Low maar ten deele; wànneer het precies gebeurde, blijft een geheim; na al mijn zoeken heb ik het opblazen (blijkbaar met kruit) niet scherper kunnen precizeeren, dan gebeurd nà ( . . ? ) Maart 1837, toen BONHAM, te voren herhaaldelijk waarnemend Gouverneur, eindelijk zelf "Governor» werd (Buckley, 1902, p. 314), en uiterlijk wel in 1840, doch zeker vóor Funi 1841, toen de eigenlijke dader de "Superintendent of Public Works», de Ier G. D. Coleman, welke dat al in Oct. 1833 door zijn protector BonHaM geworden was - Singapore verliet (Buckley, p. 227). Want dat deze energieke, maar voor oude en "rare» inscripties geen lor gevende, ingenieurarchitect de vernieler is geweest, met toestemming van zijn "com-

1 Zie Buckley o. c. (1902), p. 384-385, en 393-395, alsmede den Index achteraan dl. II. Low had zelf gehoopt Gouverneur te worden in 1843; evenals de waarnemende Gouv. E. A. Bl'nndell (Jan.-Aug. '43; o. c. p. 385). 
plaisanten» chef, den Gouverneur S. G. BonHAM ${ }^{1}$, - dàt weten we dan toch door den reeds meergenoemden ABDOELLAH bin Abdoel Kadir MoensjI, uit Hoofdstuk 13 van zijn in 1849 te Singapore in druk verschenen Autobiographie (de Hikajat Abdoellah);.... ook al heeft dan BRADDELL in zijn brokstuk-vertaling uit deze

1 Verg. de typeering van zijn persoon (een Eng..Ind. ambtenaar van den ouden stempel) bij Buckley, o. c. p. 383. Een hoogst partijdige, kennelijk-bekrompen, karakterschets èn van Bonham èn van zijn opvolger Butterworth kan men lezen in het - in 1864 voor 't eerst anoniem, daarna in $2^{\text {en }}$ druk in 1865 onder eigen naam verschenen - boek van den landmeter (Surveyor), J. T. Tномsом, "Some glimpses irto life in the Far East", p. 187-193, en 269-279. Thomson (overigens een zéér verdienstelijk, begaafd en belangstellend man) was van Nov. 1841-Aug. 1853 als Government Surveyor werkzaam geweest te Singapore; zie Buckley, o. c. p. 352 en 570 , alsmede het register i. v. Over de, bij zijn komst reeds verdwenen, inscriptie rept hij geen woord; zeker ook wel om èn zijn onmiddellijken ambtsvoorganger (CoLEMas!) èn zijn vereerden oud-Gouverneur (Bonham!) te sparen.

BбскLEY geeft in zijn boek van 1902 een heel hoofdstuk (Chapter VIII, p. 88-94) "Commercial Square and the Old Rock", d.i. over het in 1822 door Raffles aangelegde plein (in 1858 hernaamd: Raffles Place), en de inscriptie op het rotsblok aan zee. Maar het lange verhaal over deze laatste (p. 89-94) is louter een herdrukken en bijeenroegen vạn elders reeds gedrukte stukjes, zonder eigen kritisch onderzoek. Slechts aan het slot geeft hij een nog ongedrukte opmerkelijke notitie ran den welbekenden oud-Singapoerschen ingezetene W. H. READ (in Sept. 1841 er gekomen, Ned. consul aldaar van 1857-1885; zie Buckley, p. 367-369, met portret), dis het hs. van Buckley's boek te voren had gelezen (zie Preface, p. I). Dị notitie luidt als volgt (de spatieering is weder van mijzelf):

„Mr. W. H. Read writes: «I rememler a large block of the rock at the corner of Government House, where Fort Canning is now; but during the absence of the Governor [Butterworth??] at Penang on one occasion the convicts requiring stone to replace the road, chipped up the valuable relic of antiquity, and thus all trace of our past history was lost. It [ = the rock] was destroyed when the sea-wall was built round Fort Fullerton [verg. hiervóor blz. 49, en 51 noot], where the Club, Post Office [sedert 1874 ; zie toch G. M. Reith, Handbook to Singapore, $2^{\text {d }}$ ed., Sing. 1907, p. 61), and Master Attendant's Office now are. It used to be decorated with flags and offerings when at the entrance of the Singapore river [verg. blz. 33, noot! Dit moet Read van hooren zeggen hebben, want bij zijn komst te Singapore, Sept. 1841, was alles al gebeurd]. The immediate consequence of the removal [lees: opblazing] of the stone, an act of vandalism, was the silting up of the rivern." (l. c. p. 94).

Het in den eersten zin gezegde heeft een vrijwel verdachten klank, en lijkt veeleer een Singapoorsch verhaaltje, ontstaan, nadat Gouv. Butterworth het o rergebleven groote brokstuk in 1848 naar Calcutta had gezonden. Het verdere, en het in den laatsten zin gezegde is echter zeker waar; dat kon Read als Singapoersch koopman perfect weten. In zijn eigen, in 1901 te Londen anoniem verschenen, boek „Play and politics, recollections of Malaya. By an old Resident", rept Read met geen woord over den beschreven steen van weleer. 
Hikajat in Journal Indian Archip. VI (1852), blijkbaar om zijn in 1844 te Singapore overleden vriend te sparen, den Mal. tekst:

"Hingga sampai-lah tinggal batoe itoe kapada zaman toewan BonHam mendjadi Governor dalam tiga boewah něgðri, ija-itoe Singapoera, Poelau Pinang dan Malaka; maka pada masa itoe toewan CoLEMAN mendjadi [minder juist; hij was 't al sinds 1833, zie boven blz. 53] engineer di Singapoera, maka ija-lah tělah měmětjahkan batoe itoe; sajang, maka pada sangka-koe pěkěrdjaän itoe sa-kali ${ }^{2}$ tijada patoet, barangkali oleh sěbab běbalnja dăn bodohnja memetjahkan itoe, oleh sěbab ija tijada boleh mengðtahoeï itoelah di-pertjahkannja; maka tijada ija berrfikir.... kata Malayu: "Ta-boleh di-baïki, djangan dipetjahkan»". (transcriptie-SHELlabEAR, I, 1907, p. 168)

aldus gelieven te vertalen (1. c. p. 601):

„During the time Mr. Bonham was governor of the three Settlements this stone was broken up by the Engineer. This is very much to be regretted, and was in my opinion highly improper; perhaps the gentleman did it from ignorance or stupidity, and now, from his conduct, we can never know the nature of this ancient writing. Did he not think that persons sufficiently clever might come and disclose the secret, so long concealed? I have heard that in England there are persons very clever in deciphering such inscriptions, with the aid of all manner of curious devices. Well may the Malays say "what you can't make don't break»."

Men kan nu begrijpen, wààrom Braddell den naam van dezen "gentleman», die wegens zijn «ignorance or stupidity» zoo ongezouten op zijn brood kreeg van den begaafden kwartbloedArabier Abdoellah, wegmoffelde. Maar men kent toch óók nog Schiller's "Die Kraniche des Ibikus»? Het is mij aangenaam, zoo'n Korinthische kraanvogel hier te zijn.

Te Calcutta vielen de 3 door Low overgestuurde steenplaten met (Oudjav.) letterschrift gelukkig in de beste handen: in die van den tweeden secretaris der Asiatic Society of Bengal, den epigraaf J. W. LaIdLay. Deze liet, onmiddellijk volgend op het opstel van Low waarvan hierboven het slot - feitelijk een post 
scriptum - werd teruggegeven, een eigen opstel volgen, getiteld "Note on the Inscriptions from Singapur and Province Wellesley, forwarded by the Hon. Col. Butterworth, C. B. and Col. J. Low", vol van treffend-juiste opmerkingen en gelukkig met een Plate III, af beeldende de 3 door Low overgezonden brokstukken (schaal niet vermeld helaas); welke in $\mathbf{1 8 8 4}$ aan Prof. KerN de gelukkige gelegenheid gaven om te constateeren: $1^{\circ}$. LAIILAY had volkomen goed in 1848 gezien: het was Kawi-schrift; $2^{\circ}$. eenige regels, een 4 -tal op de 3 brokstukken met samen ca. 17 regels, kønden zelfs gelezen worden, maar zònder begripsverband te geven ; $3^{\circ}$. tegen den indertijd door Begbie en Laidlay vermoeden ouderdom dezer inscriptie als \pm 1230 , bestond "geen bezwaar». ${ }^{1}$

Doch, zooals straks (blz. 51) al ter loops werd opgemerkt: het $4^{\circ}$ en veel grootere fragment, dat wat Gouverneur BUTTERWORTH in begin 1848 rechtstreeks uit Singapore naar 't Museum te Calcutta had gezonden, is in dat jaar onafgebeeld gebleven, en à plus forte raison tot heden ten dage onontcijferd. Want ziehier de gewichtigste zinnen uit het mooie opstel van LAIDLAY: ${ }^{2}$

"The great interest expressed by the late James Prinsep [ $\dagger 22$ April 1840 te Londen] and other antiquarians in the remarkable inscription at Singapur induced $\mathrm{me}^{3}$, as mentioned in a former number of this Journal [hier wordt dus het Februari-nummer bedoeld, en daarin ButTERWORTH's stukje over de "Inscription at Singapore» (J. A. S. B. XVII, 1848, Part I, p. 154-155), met inleidend woord van LAIDLAY-zelven], to apply to the present esteemed Governor of the Straits Settlements, the Hon. Col. Butterworth, C. B. to secure for the Society's Museum any fragments that might remain after the gothic exploit alluded to by Col. Low [in 't onmiddellijk voorafgaande stuk, Part II, p. 66; zie daareven]; a request he was pleased very

1. Thans is deze studie van KERN „Over eenige oude Sanskrit-opschriften van 't Maleische Schiereiland" (Versl. en Meded. K. Ak., afd. Letterk., 3, I, 1884), herdrukt in zijn Verspr. Geschr. III (1915), p. 255-262. Zie er p. 261-262.

3 In de Juli-afl. 1848; J. A. S. B., XVII, Part II (loopend over Juli-Dec.), p. 66-72. De belangrijkste zinnen heb ik gespatieerd. In de Aug.-afl. 1848, werd de verschijning van dit opstel door de Proceedings (l. c. p. 234) aldus genotuleerd: „A note on the Singapore Rock inscription, of which fragments had been forwarded by the Hon. Col. Butterworth, and Lieut.-Col. Low, by Mr. Laidlay."

${ }^{3}$ Hier is dus "me" = Laidlay. Verg. hiervóór blz. 50 noot. 
kindly and promptly to comply with. Since then Col. Low has forwarded several other pieces, and though in possession of but a small portion of the original inscription, and that evidently not the most legible, I felt bound, in justice to the obliging donors, to bestow some labour in attempting to decypher at least its character (aanhef; p. 66-67).

$[\mathrm{Nu}$ volgt eerst een volledige aanhaling van 't gevoelen van PrINSEP uit 1837 , in J. A. S. B. VI, p. 680-681, die het schrift had aangezien voor "Pálí». Dan gaat Laidlay voort:]

"The condition of the inscription was, indeed, far worse than I supposed, and seemed to preclude all hope of decyphering the characters. $\mathrm{By}$ a fortunate expedient however, and by very patient study, I have been able to make out sufficient to determine its language and probably date with tolerable certainty. The method I adopted, and which may be useful in similar cases to others, was to strew finely powdered charcoal (animal charcoal is better than vegetable, as being specifically heavier) over the surface of the stone, and sweep it gently to and fro with a feather so as to fill up all the depressions, the very slightest of which was thus rendered remarkably distinct by the powerful contrast of colour. By this means and by studying the characters in different lights, I have succeeded in decyphering so much of three of the fragments [er zijn dus méér dan 3 kleinsoort brokken te Calcutta!] as is depicted in plate III [óók gereproduceerd in den gezegden herdruk door Dr. Rost, 1886, dl. I, tegenover p. 228: maar ook weer iets verkleind, verg. hiervóór blz. 36 noot].

It will be seen from the plate that though many of the characters resemble the square Pali in form, and hence misled Prinsep to conclude that the inscription was in the Pali language, yet others, and these amongst the most distinct, bear no resemblance whatever to that type.... As the character could not be identified with that of any of the published Singalese inscriptions, I was induced to compare it with the alphabets of the Archipelago, and $I$ find it to be identical with the Kawi, or ancient sacred and classical language of the Javanese, spec- 
imens of which may be found in Wilhelm von Humboldt's Ueber die Kawi Sprache vol. 2 [1838], and in Sir S. Raffles's History of Fava [1817 of 1844]. We have also in our museum [hoort, hoort! bedoeld wordt de steen van den berg Penanggoengan, met ERLANGGA's oorkonde van 959 en 963 Çaka in Sanskrit èn Oudjavaansch, maar beide in Kawi-karakters] a very fine inscription in that character, which has been taken by many for a peculiar form of Sanskrita. ${ }^{1}$ With the alphabet of this language, as gathered from similar inscriptions, I can identify all, or nearly all, of the characters; but of course no clue to the purport of the inscription can be obtained without some knowledge of the language itself.

Fig. 1 seems to have been from the upper part of the inscription, and is entirely omitted in Prinsep's lithograph as effaced [een scherpe lijn van boven op deze fig. 1 duidt blijkbaar de afgrenzing van het bovenste stuk aan, dat in Prinsep's Plate XXXVII van 1837 totaal zeggelaten was; hier las Prof. Kern in 1884 van regel 3: satāgalalasayanara]. Figs. 2 and 3 I cannot identify with any portion of Prinsep's plate, much on the right hand side of which seems to have been so distinct, that I make no doubt had that portion been available, we might have easily transcribed continuous sentences. [Hier las Kern op fig. 2, regel 2 en 3, resp.: ya-āmānavana en: kesarabharala; op fig. 3 r. 6: yadalama. Fig. 1, 2 en 3 vertoonen resp. $3 \frac{1}{2}, 6$ en 7 regels.] ${ }^{2}$

The much larger fragment forwarded by Col. Butterworth, still remains to be decyphered; but I confess I feel little inclination for that barren labour until there appears some probability of the language being translated [op dit $4^{e}$, véél grootere, brokstuk, thans evenzeer nog in

1 Dit is wel de oudste Museum-toespeling op dezen zgn. „Calcutta-steen"; niet opgenomen in Verbeek's Oudheden van Java, 1891, p. 225; noch in de $2^{\circ}$ ed. in Rapporten Oudh. Dienst 1915 (1918), p. 251. Zie nog blz. 96, noot 1.

2. Bij deze lezing van 4 brokstuk-regels uit de in totaal afgebeelde $16 \frac{1}{2}$, teekende Prof. Kern aan: „Verondersteld dat er in 't facsimile geen klinkerteekens en Anusrāra's verwaarloosd zijn, zie ik geen kans de lettergrepen zóó te scheiden dat er een onmiskenbaar Oud-javaansch woord te voorschijn komt. Ik durf echter geenszins beweren dat het stuk in eene andere taal opgesteld is." (p. 261-262). 
de kelders van het Indian Museum te Calcutta ${ }^{1}$, moet dus alleréérst de aandacht van een Ned.-Indisch epigraaf zich concentreeren!]. Meanwhile we may conjecture with probability that the inscription is a record of some Javanese triumph at a period anterior to the conversion of the Malays to Muhammadanism, and.... (1. c. p. $67-68$ ).

[ $\mathrm{Nu}$ gaat Laidlay aanhalen uit Begbie's boek van 1834 (zie hiervóór blz. 37-40); Laidlay verwerpt, evenals Begbie, Verhaal 9-10 der Sadjarah Malajoe, in verband met de Singaporeinscriptie; doch staat stil bij Verhaal 6, den worp van athleet Badang; Laidlay zwijgt echter over VERHAAL 1 (evenals Begbie), zwijgt dus over hetgeen waarop Low 2 pp. daarvóór had "alluded" in het eigen J. A. S. B. waarvan Laidlay een der invloedrijkste mede-redacteuren was als $2^{\text {e }}$ Secretaris der As. Soc. of Bengal; en welke toespeling dd. " 1 st July, 1847 " te lezen stond in de $3^{\mathrm{e}}$ of Sept.-afl. van het in 't vorig jaar te Singapore in 6 nummers compleet gekomen Journal Indian Archip., vol. I, p. 89, weggestopt in een geologisch opstel. Dàt heet nog eens onvindbaar verstoppen. ${ }^{2}$ Laidlay sluit dan aldus zijn betoog:]

„At all events we may be certain that the present inscription is not less, and cannot be much more, than 600 years old. Its preservation for so long a period may be ascribed in a great measure to its protection from the action of the weather by the tropical vegetation which concealed it, perhaps for centuries. "You remember», writes Dr. Montgomerie [d. i. de militaire

1 Thans echter, sinds 1919 of 1920, bevinden zich alle fragmenten in bruikleen in 't Raffles Museum te Singapore. In het gedenkboek "One hundred years of Singapore" (London 1921) leest men toch, na een overzicht der lotgevallen van "The Singapore monolith" (p. 573-576): „During 1918 the Committee of Management of the Raffles Museum and Library moved in the matter of the return of the one or more fragments to Singapore as being a more fitting home for them; and the Calcutta Museum has kindly agreed to send such as there are to Singapore, on an extended loan." (I, p. 576). En zie er ook op p. 4 een foto van hetzelfde fragment van Low, dat als fig. 3 staat op Laidlay's Plate III van Juli 1848. (Correctie-noot ran Maart 1921).

2 Noch in de vrij uitvoerige Contents vooraan, noch in den zéér uitvoerigen General Index achteraan dit dl. I is iets van Low's alinea over de „ancient inscription" (zie den tekst hiervóór, blz. 49) te vinden. Dit dl. I verscheen in 6 afl., latere deelen in 12, elke maand één; afl. 1 van Vol. I was dus in Juli 1847 verschenen (Buckley p. 467, zegt: June). 
dokter W. Montgomerie, ingezetene van Singapore van begin 1819-1843, † te Barrackpore 1856, een man van groote algemeene belangstelling, zie Buckley, o. c. 1902, p. 401-402; en welke ook in ca. 1847 aan Laidlay het éérst het opblazen had medegedeeld van den Singaporerotssteen, ${ }^{1}$ nadat Montgomerie in 1843 verplaatst was geworden naar Fort William te Calcutta], "the situation of it on the rocky point on the south side of the entrance of the Singapore Creek. That point was covered with forest trees and jungle in 1819 , and the stone was brought to notice by some Bengal clashees [Hindī: chalāsī $=$ matroos] $^{2}$ who avere employed by Captain Flint, R[oyal] N.[avy] (the first Master Attendant); the men on discovering the inscription were very much frightened, and could not be induced to go on with the clearing, which, if I recollect right, was completed by Chinese under the stimulus of high wages. What a pity 't is that those who authorized the destruction of the ancient relic [versta: de in Jan. 1843 afgetreden Gouverneur S. G. BonHAM!] were not prevented by some such wholesome superstition!»" (1. c. p. 70)

Hier, in dit slot over de Singapore-inscriptie - want vervolgens gaat Laidlay spreken over de inscripties uit Prov. Wellesley, door Low ook overgezonden, maar alleen in nateekening en klei-afprent - wordt dan tevens door den ouden Singapore-

1 De anonieme, maar door den $2^{\text {en }}$ Secretaris der As. Soc. of Bengal (LaidLaY) gestelde inleiding tot het hiervóór (blz. 52-53) afgedrukte stukje van Gouverneur Butterwortb, luidt toch in haar slot als volgt:

„On learning from Dr. Montgomerie that this rock [at the jetty of Singapore] had been blasted some years ago, I [= Laidlay] vèntured to solicit the present Governor, the Hon. Col. Butterworth, C. B. to secure any legible fragments that might yet exist; and have since received his kind promise to forward such to the museum of the Society [of Bengal], where I trust the practised eyes of our antiquarians [waarvan Laidlay-zelf een der besten was] may yet decypher enough of the legend to determine its purport. Col. B. observes:-" [en nu volgt, wat staat op blz. 52-53]. (o. c. p. 154).

Met zijn aanhef "You remember" van hierboven, herinnert Dr. Montgomerie blijkbaar aan een vroegere mededeeling (hetzij schriftelijk, hetzij mondeling), door hem over de situatie ran den beschreren steen gedaan; men moet er niet uit lezen, dat degeen welke die vroegere mededeeling ontving [= Laidlay te Calcutta] zelf de inscriptie in situ had gekend weleer.

"Zie Yule-Burnekl's Hobson-Jobson (1886 of 1903) i. v. „Classy, Clashy”. Onze Jan Compagnie zei: Orang Klaasjes (zie Encycl. N.-I., $2^{\circ}$ ed. III, 1919). 
ingezetene, Dr. Montgomerie, de ontdekking van den beschreven steen in (vermoedelijk: Juni) 1819 onthuld, op het terrein van den éérsten Havenmeester van Singapore, Capt. W. Flint; ${ }^{1}$... die in 1811 getrouwd was met de eigen oudste zuster van RAFFLES, Mary Ann Raffles, in 1805 meegegaan met haar broer naar Pinang, daar getrouwd met een Mr. Thompson, weduwe geworden in 1809 , en vervolgens in 1811 hertrouwd met Flint bovengenoemd. Wanneer nu Raffles te Singapore vertoefde in zijn kwaliteit van Gouverneur (6 Febr. 1819-9 Juni 1823), "he had used the upper floor of Captain Flint's house as an office» (Buckley 1902, p. 194); welk huis van Flint weer in de tweede helft van 1819 gebouwd was "at the end of the point [of Singapore River] near the present Master Attendant's Office» (ib. p. 53). M. a. w.: Raffles die het ${ }^{\circ}$ huis van zijn zwager Flint te Singapore als bureau gebruikte, zag dan uit de ramen daarvan als het ware néér op den beschreven steen, die hem zóózeer interesseerde; en waarvan een bezoek zoo vermakelijk door Abdoellah Moensji wordt verhaald, in gezelschap met Raffles en den Holsteinschen zendeling G. H. Thomsen, waarbij Raffles het schrift reeds als «Hindoe» aanzag, daarbij den invloed der Hindoe's op Java en den heelen Archipel releveerend. ${ }^{2}$ Is het dan niet verbazing-

1 Dr. Montgomerie schrijft de ontdekking dus toe aan Bengaalsche matrozen van den havenmeester Capt. Fr.ıNT; Begbie in zijn boek van 1834 (zie hiervooór blz. 38) spreekt van het opstellen van een vlaggepost in ca. 1829 op een wellicht toch andere - "large rock", ók "at the mouth of the river" (welke laatste dan het rotsblok van het Badang-verhaal zou zijn geweest in de Sadj. Mĕl.) door Capt. Jackson. Nu was Lieut. P. Jackson van vóór Nov. 1822- nà 1827 "executire engineer and surveyor" te Singapore (Buckley, p. 84, 166, 201); terwijl Flint toen in 1827 (dus nà het vertrek van Crawfurd als Resident) nog steeds was „Master Attendant and Postmaster" (ib. p. 201; het "Assistant Master Attendant" is een schrijffout, zie toch p. 202).

Voor de boven gegeven personalia over Flist, zie D. Ch. Boulger's „The life of Sir Stamford Raffles" (1897 of 1899), p. 54 (en 21). Bij Buckley p. 64 blijkt, dat Flint pas op 24 April 1820 te Singapore aankwam; de daaraan voorafgegane aankomst uit Engeland door Straat Soenda te Batavia, en de hier gewisselde 3 curieuze brieven met den Gouv.-Secr. J. E. Brand, dd. 29 Maart, 6 en 8 April 1820, kan men vinden in de Memoir (1830), p. 441-443. De plek voor Flint's woning was echter door Raffles persoonlijk in Juni 1819 uitgekozen te Singapore (zie Buckley, p. 55-56, juncto Nemoir p. 379-402); en dit kan dus zeer wel de juiste tijd zijn geweest der ontdekking van de inscriptie. Zie ook de nu volgende noot, welke goed hiermee dan klopt.

2 Naar de vertaling van brokstukken uit de Hikajat Abdoellah (gedrukt te Singapore, 1849) door Th. Braddell in Journ. Ind. Arch., VI (1852), p. 585-604, was Abdoelcan, samen met „Padri T -" (versta: zendeling G. H. Thomsen 
wekkend, dat er in de verschillende brieven door Raffles uit Singapore geschreven aan Marsden en andere mannen van beteekenis, afgedrukt in de Memoir-uitgave van 1830, niet ééne zinsnede over die Singapore-inscriptie te vinden is? 1

Haast even verbazingwekkend is, dat JoHN CRAwFuRd, welke onmiddellijk in geestelijke beteekenis voor de kennis van onze Oost volgt na Raffles, hooger wel staande dan Marsden en Leyden, en die, als "Resident" te Singapore FARQUHAR opvolgend, drie jaar lang (9 Juni 1823-14 Aug. 1826) in de gelegenheid was geweest den ongerepten Singapore-steen waar te nemen, in zijn *Descriptive dictionary of the Indian islands and adjacent countries» (London 1856) de volgende afwijkende doch tevens aanvullende beschrijving geeft van de situatie, i. v. "Singapore, 2 :

van hierboven), in the fourth month of the establishment of Singapore" aldaar voor het eerst aangekomen, uit Malaka (p. 597), waar Abdoellah geboren, getogen, en getrouwd was; d. i. dus: in Mei 1819. Er was toen nog niet "a single house on the other side of the river" (ib.); d.i. dus op den N. oever der Singapore-rivier, de "Campong Glam side" (p. 600), die later en thans nog Beach Road kwam te heeten Abdoellah vertelt dan éérst van het wegruimen van "the hill at the end of Singapore point". (ib.), d. w. z. het emplacement van Commercial Square (thans: Raffles Place) aan de Z. zijde der rivier; en gaat dan dadelijk door:

"At the end of the point [n.l. "Singapore point", aan dien Z. oever] there was another rock found among the brushwood, it was smooth, of square form, each side about a fathom in length [dus ca. 1.80 M. in 't vierkant; terwijl Bland gaf: voorvlak ca. $3 \times 3 \mathrm{M}$., inscriptie $2,10 \times$ ca. 1,90 (nl. $1.50+$ ca. $\frac{1}{4}$ ), zie hiervóór blz. 36, en noot; de Mal tekst zegt: "ada kira-kira sa-děpa lebarnja, ampat persĕgin], and all covered with a chiseled inscription, which no one could read, as it had been worn away by water, for how many thousands [!] of years God alone knows. As soon as it was discovered, people of all races crowded round it. The Hindoos said it was Hindoo writing but they could not read it. The Chinese said it was in Chinese character [!]. I went among others, accompanied by Mr. Raffles, and Mr. Thomsen [zóó terecht gespeld; later meestal foutief "Thomson", zelfs "Thompson"]. I thought, from the appearance of the raised parts of the letters, that the character was Arabic[!].... Ingenuity was exhausted in trying to decipher the inseription. The stone remained there, subject to the flow and ebb of the sea, till lately [versta dus: 1838 , '39, of '40]. Mr. Raffles said that the inscription was Hindoo,.... But not a soul in Singapore could say what the inscription was." (p. 601). Is dit consult der 3 natiën van Vreemde Oosterlingen bij den steen niet verrukkelijk? - Onmiddellijk volgt dan het verhaal der vernieling (zie blz. 55 hiervóór).

1 Of had Raffles dit onderwerp stil voor zich gehouden voor later publicatie in Europa, in zijn (ongeboren) boek "Notes on the Eastern Islands" (zie toch het na zijn dood gevonden memorandum in Memoir, 1830, p. 601)?

2 De belangrijkste zinnen werden weer door mịj gespatieerd. In dl. I (1886) der Miscellaneous Papers relating to Indo.China is dit belangrijke 
"The account given by De Barros, and which he states to have been derived from the natives, makes the colony, which fled from Singapore and eventually established itself in Malacca, to have been Javanese, which is, in fact, virtually the same as the assertion of the Malays themselves, that it came from Palembang. The relics, very rude ones, discovered on the ancient site of Singapore, which is also that of the modern town, afford some corroboration of this opinion. The most remarkable of these is an inscription on a great mass of unhewn white [sic] sandstone. This nodule has been split in the centre, the two fragments lying opposite to each other, at about an angle of forty degrees, and at the base not above a couple of feet apart. The writing is on the two opposing faces of the rock, which itself seems to have been adopted for this purpose on the very spot where it lay, being still surrounded by several other masses of the same description. Nothing of the kind can be ruder. By time and the decomposition of the rock, most of the writing has been obliterated, although here and there a few letters are sufficiently district. These are, in form, rather round than angular, and, making allowance for the material and the rudeness of the execution, they bear the greatest resemblance to Kawi or the ancient writing of Java, the same which is found in most of the old monuments of that island. At all events, they bear no resemblance whatever to the Rejang of Sumatra, the character used by the majority of the people of Palembang, nor to the Korinchi, that in which the Malays most probably wrote before their adoption of the Arabic letters.

The other relics discovered are equally rude with the inscription. These were, the remains of an earthen wall, a fosse [dus de parit Singapoera uit Verhaal 10 der Sadjarah Melajoe, zie hiervóór blz. 34], a sepulchre, and a supposed temple on the hill behind the town, on which now stands the government house [sedert

laatste, evenals CRAwFurd's allereerste en analoge getuigenis over de Singaporeinscriptie (dd. 4 Febr. 1822, zie ons IIe Gedeelte, sub II), geheel over het hoofd gezien. Dennys in zijn Descriptive dictionary of British Malaya (1894) herdrukte het bovenstaande uit 1856 i.v. Singapore (History), en vulde het aan. 
Mei 1859: Fort Canning]. Some old Chinese coins, such as formed the currency of all the civilised nations of the Archipelago, and still continue to do of some of them, were found among the ruins. The oldest of these bears the name of a Chinese emperor, who died in 967 of Christ, ${ }^{1}$ which carries us back to some 200 years before the supposed foundation of Singapore in the year 1160." (1. c. p. 402).

Dit opmerkelijke samenvattende stukje van Crawfurd, in hoofdzaak blijkbaar samengesteld uit zijn oude aanteekeningen van omstreeks $1825^{2}$, wonderlijk defect omdat hij nog niet eens wist van de vernieling der inscriptie in ca. 1838, verblijdend volledig omdat hij ók spreekt over de anderé, - thans, op één na, evenzeer spoorloos verdwenen ${ }^{3}$ - overblijfselen in zijn Residentstijd van het antieke Singapore, verheldert misschien iets van de hiervóór afgedrukte opmerking van Laidlay, dat hij twee der vrij goed bewaarde brokstukken van Low (fig. $2-3$ zijner Plate III) in 1848 niet kon terug vinden op het facsimile van Prinsep uit Aug. 1837. Misschien ook verheldert het eenigszins, hoe Dr. Bland in voorjaar 1837 kon spreken van een inscriptie "originally...

1 Dennys, zelf Sinoloog, voegde bij den herdruk van Crawfurd's art. uit 18.56 in zijn Dict. van 1894 het volgende hier toe : "This, however, affords no evidence whatever, old Chinese coins of similar age being frequently found in the strings of cash current at the present day in China." (p. 348).

"Precies: van 4 Febr. 1822. Zie toch ons IIe Gedeelte, sub II.

3 Die ééne uitzondering is de zgn. kramat Iskandar Sjah (Shrine of Iskander Shab), op de Noordhelling van Fort Canning Hill bij het Old Cemetery aldaar met zijn "stucco-covered tomb"; zie de nadere beschrijving in Reith's Handbook to Singapore, $2^{d}$ ed. 1907, p. $65-66$ : "The shrine is believed to be the resting-place of the Sultan Iskander, one of the heroes of the Sejârat Malayu, on what authority it is hard to say." Op mij maakte dd. 3 Juni 1909 dit koepel-vormig graf (koebah) een dergelijken 17-eeuwschen indruk als later de graven van 3 Sultans van Bima, of die van de Vorsten van Goa bij Makasar. Alle inscriptie ontbreekt; op Vrijdag- en Zondag-avond wordt dit graf door veel inlanders bezocht. Het werd in 1819 op dezen heuvel van ca. $45 \mathrm{M}$. hoogte, welke toenmaals heette Boekit Larangan, „Verbods-heuvel”, ontdekt. Dat er indertijd vóór den bouw van Fort Canning (1859), méér Mal. Vorsten(?)graven daar op den heuvel waren, schijnt te volgen uit deze zinsnede van Raffles in zijn brief dd. Singapore 23 Jan. 1823 aan de Hertogin van Somerset: „However,..., I preferred ascending the hill of Singapore, where, if my bones must remain in the East, they would have the honour of mixing with the ashes of the Malayan kings" (Memoir, 1830, p. 535). Zie ook Buckley (1902), i. v. Bukit Larangan, Cemetery, en Fort Canning. Het Eng. Old Cemetery werd gebruikt van $1822-1867$ (zie Reith, o. c. p. 60). 
of about fifty lines», Prinsep een facsimile kon geven van 40 regels, zonder iets van de "about 12 lines» daarboven, terwijl Laidlay dan toch een brok der éérste 4 regels gaf in fig. 1 (zie blz. 58). Doch hoe er harmonie kan worden gebracht tusschen de 3 beschrijvingen van den beschreven steen, die van Crawfurd uit ca. 1825 (gedrukt in 1856), die van Dr. Bland (gedrukt in Aug. 1837 door Prinsep) ${ }^{1}$,

1 De letterlijke woorden van Bland (hiervóór, blz. 36, reeds in hoofdzaak weergegeven) zijn, met spatieering van het ten deze belangrijkste:

nOn a tongue of land forming the termination of the right bank of the river at Singapore, now [= in voorjaar 1837; zie toch hieronder, en blz. 37 hiervóór] called Artillery Point [een naam, nog niet voorkomend in Begbie's boek van 1834, waarover 3 jaar werd gewerkt; yie er de Introduction p. VIII, en tekst p. 351], stands a stone or rock of coarse red sandstone, about ten feet high, from two to five feet thick, and about nine or ten feet in length, somewhat wedge-shaped, with weather-worn cells. The face sloping to the south east [d. i. dus: van de monding der rivier, naar zee toe] at an angle of $76^{\circ}$ has been smoothed down in the form of an irregularsquare, presenting a space of about thirty-two square feet [dus: $32 \times 0,0929 \mathrm{M}^{2}=$ 2,97 M² ; Prinsep's fac-simile geeft: $2,10 \times 1,50 \mathrm{M}$. = $3,15 \mathrm{M}^{9}$, maar zonder het bovenstuk van 10 à 12 regels], having a raised edge all around [dus: de opstaande rand was toen rondom intact, zou men zeggen; dit schijnt sterk te pleiten tegen Crawfurd's later gedrukte beschrijving].

Onthis surfacean inscription has originally been cut of about fif ty lines, but the characters are so obliterated by the weather, that the greater part of them are illegible. Still, there are many left which are plain enough, more particularly those at the lower right-hand corner [dus: den kant die het dichtst bij het water way], where the raised edge of the stone has in some measure protected them." (Journ. As. Soc. Bengal, VI, 1837, p. 681).

Dan vertelt hij, hoe hij "with the assistance of a clever native writer" vrage: Aвdoflda Monnsur? - van letter voor letter afdruksels makte met "well made and soft dough"; en dan: „when the impression of one character was taken and copied, the letter itself in the stone was painted exactly over with white lead [=loodwit], as far as the eye could make it out, when the character was copied a second time, and if the two agreed, it was considered as nearly correct as possible, and although this was done to all the characters, it was more particularly attended to in the more obscure ones, for the letters marked in the faesimile with more strength, could readily be copied by the eye. [Ook hierin blijkt weder niets van een in tweeën gebroken inscriptie ]

„There is another thing worthy of being noticed, which is, that after a few days' work, we discovered that when the sun was descending in the west [bij een stand van $76^{\circ}$ helling naar het Z. O. dus om 2 à 3 uur 's middags], a palpable shadow was thrown into the letter [d. i. dus slagschaduw van boven naar beneden in de ingegrifte letters], from which great assistance was derived. No doubtful letter has been admitted in the facsimile sent for your [= PrINSEP's] supervision, and it may be fairly doubted whether you will ever get a better or more honest copy." (1. e. p. 681-682). -

De ontvangst van dit facsimile te Calcutta werd in de Proceedings van Dl. 77. 
en die van Begbie (in zijn boek van $1834,{ }^{1}$ het minste zeggend), blijft een raadsel. Want Crawfurd spreekt duidelijk van een in 't midden gespleten rotsblok, daarop in atwo fragments, onder een hoek van ca. $40^{\circ}$ - kennelijk aan de onderzijde, van binnenuit, geschat - inéén (niet: uiteen) gevallen, en met schrift "on the two opposing faces of the rock.»En ook nadat het mij lukte de oorspronkelijke éérste aanteekeningen van Crawfurd over deze inscriptie dd. 4 Febr. 1822 terug te vinden (zie hierna ons Tweede Gedeelte, sub II), bleef die scherpe tegenspraak bestaan.

Met dit raadsel sluit de droeve verniel-geschiedenis van dit kostbare historisch monument. Er is nog slechts een zwakke hoop, dat uit de een of andere Engelsche reisbeschrijving van vóór 1840 eenige zinnen zullen worden opgediept, die beslissen kunnen wie het best en zuiverst heeft beschreven: CraWfurd, of BLAND. Naar ik stellig vermoed: de laatste.

Toch is allerminst uitgesloten, dat het raadsel der Singaporeinscriptie alsnog wordt benaderd, zelfs ten deele onthuld. De sleutel tot het geheim ligt nog steeds te Calcutta, in de kelders van het tegenwoordige Indian Museum ${ }^{2}$ : het $4^{\mathrm{e}}$, groote, fragment,

Aug. 1837 aldus genotuleerd: „Dr. BLAND of H. M. S. Wolf presented a facsimile of the ancient inscription on the point of the jetty [ = havenhoofd; Fransch jetée] at Singapur. (Printed in the present number.)" (1.c. p. 709):

Daar de Wolf op $29 \mathrm{Mei} 1837$ van Singapore naar Calcutta vertrok met gevangen genomen Mal. zeeroovers (Buckley, 1902, p. 277), is het facsimile daarmede zeker wel medegegaan. We mogen dan Juni 1837 aannemen als uiterste termijn (tot heden te vinden), dat de Singapore-inscriptie gewis ongedeerd in loco lag; Gouverneur Bonham was in Maart 1837 als zoodanig geinstalleerd (Buckley, p. 314). Dat Prinsep zelf de litho makte naar Bland's facsimile, was niets ongewoons; ook tal van andere inscripties lithografeerde hij voor het Journal.

Wie echter Luitnt. C. MACKEnzıE was, die op rerzoek van Prinsep getracht had een facsimile te maken vóór Bland, is me niet gelukt uit te vinden. In zijn inleidend woord tot Bland's notitie vermeldt Prinsep dit aldus: „the last friend, Lieutenant C. Mackenzie, who kindly undertook the commission [scil.: of copying], gave it up in despair at its very decayed state." (1. c. p. 680).

1 De beschrijving door Begbie luidt: „The principal curiosity of Singapore is a large stone at the point of the river, the one face of which has been sloped and smoothed [dus conform BLAND; en contra Crawfurd]; and upon which several lines of engraven characters are still visible. The rock being, however, of a schistose and porous nature, the inscription is illegible. It is said that Sir Stamford Raffles endeavoured, by the application of powerful acids, to bring out the characters with the view of decyphering them, but the result was unsuccessful." (o. c. p. 355).

2 Thans (1921) dus in 't Raffles Museum, Singapore. Zie blz. 59, noot 1. 
in 1848 rechtstreeks door Gouv. Butterworth er heen gestuurd, met een blijkbaar tamelijk welbewaarde legende, werd door Laidlay ter zijde gelaten omdat hij niet wist in welke taal zij was. Dit groote brokstuk "still remains to be decy phered», zie hiervór blz. 58! Toen Dr. Krom in 1910 Calcutta en het Museum bezocht, hoorde hij op zijn navraag zeggen dat er in de kelders nog fragmenten lagen van een inscriptie uit Singapore; gelegenheid om ze daar te bezichtigen, was toen echter niet aanwezig.

Maar naar aanleiding van mijn betoog, hiervóór blz. 34-35, dat Verhaal 10 der Sadjarah Malajoe m. i. duidelijk spreekt over een triomftocht tijdens Vorst Hajam Woeroek uit Madjapahit naar Singapore, die dan in ca. 1360 A. D. moet hebben plaats gehad, en mijn vraag op blz. 39, of dan niet de Oudjavaansche Singapore-inscriptie "uit ca. 1360 A. D.» zoude zijn, heeft de heer Krom mij veroorloofd, nadat hij de af beēlding der 3 fragmenten van Low op Laidlay's Plaat III uit 1848 nog eens nauwkeurig bekeken had, het volgende hier mede te deelen:

"Naar aanleiding van het "ca. 1360 A. D.?» bij de Singaporeinscriptie, diene, dat ik schrift-eigenaardigheden van de gepubliceerde fragmeriten van dien steen in het bijzonder terugvond op Majapahitsche oorkonden. Dat klopt dus prachtig. Ik voor mij zou, uitsluitend op het schrifttype afgaande, den steen echter wat vroeger dateeren dan 1360.»

Er moet nu getracht worden, tastenderwijs en aarzelend en gehéél voorloopig, de gegevens die tegenwoordig ten dienste staan samen te vatten omtrent de mogelijke geschiedenis in den loop der eeuwen van Singapore, en daarmede tevens omtrent de stichting van Malaka.

Voor alle duidelijkheid zal ik de vragen die daarbij oprijzen, splitsen in 4 historisch scherp-onderscheiden tijdvakken: tot ca. 900 A. D. (bloeitijd van Midden-Java); ca. 900-1200 (opbloei van een politiek-overmachtig Oost-Java); 1225-1292 (Toemapěl's bloeitijd); 1300-1400 (Madjapahit's bloeitijd).

De dăaraan verbonden vragen gelden voor de eerste twee perioden alléén $\mathrm{Sing}$ apore.

A. Kan Singapore voór 900 A. D. hebben bestaan?

Niet onmogelijk wèl. Onder welken naam dan, aannemelijkerwijs? Onder dien van Hasin $=$ "Zilt»-stad, tevens "Zee»-stad, 
de stad van het Zilte nat (verg. V. d. Tuuk' Kawi-Wdb. I, 1897, p. 204-205), en dan zelfs onder dien van Māhasin of Maha$\sin =$ "Groot-Hasin $;^{1}{ }^{1}$ alsdan reeds in ca. 690 gedocumenteerd in I-tsing's Mo-ho-hsin (Beal spelde Mo-ho-sin), en aanduidend een toenmaals overmachtigen staat aan de Zuidpunt van het Maleische schiereiland; contemporair in dat geval met $\mathrm{P}^{\prime} \mathrm{o}-1 \mathrm{u}-\mathrm{shi}=$ Baroes, Mo-1o-yu= Djambi, Shih-1i-fo-shih= Çrībhodja $($ Beal $)=$ Çrī Widjaja (Coedès) $=$ Palembang, en Ho-ling $=$ Kaling(ga) $=$ Midden-Java. Verg. hierbij Takakusu's editie van I-tsing, 1896, p. XXXIX-XLVIII; en blz. 9 noot hiervóór.

Mocht deze conjectuur in later jaren juist blijken, dan zou de geschiedenis van dit Hasin - waarvan we den authentieken naam straks zullen ontmoeten sub B, in 956 Caka - zeker niet ongedeerd zijn gebleven in de periode der inscriptie van Kota Kapoer uit 608 Çaka $=686$ A. D., I-tsing's eigen tijd; waarvan nu, dank zij Dr. Coedès, Dr. Krom e.a., als straal in een duisteren nacht, aan het licht begint te komen: dat toenmaals de politieke expansie van Palembang niet alleen op en om en bij Suınatra overmachtig werd, maar zelfs - gesteund door eufemistische woorden in de Tjanggal-inscriptie (Kèdoe) van 654 Çaka - geducht zich tijdelijk liet gevoelen op Midden-Fava.

Voorloopig zouden we dan zelfs zóó kunnen onderstellen: in 608 Caka doet Palembang een welgelukten scheepstocht tegen Vorst SANNA ( den Vertwijfelende») in Midden-Java, opvolger van Vorstin-Regentes SìmA (ca. 674-685 A. D.), en sticht ter herinnering aan die overwinning in $686 \mathrm{~A}$. D. op de (waarschijnlijk met Midden-Java politiek. verbonden) Westkust van het tegenover Palembang dreigend gelegen groote eiland Bangka den waarschuwings-steen van Kota Kapoer (als een soort Cave Palembang!); ${ }^{2}$ maar eenigen tijd daarna, zeg in ca. 700 A. D., weet die Vorst SAnNa (ca. 685-725), alias SANNĀHA, terug te slaan, vernedert Palembang, brengt gevangen Maleiers mee naar huis, en wijst dezen woonplaatsen aan in Noord-Kðdoe en in den

1 V. d. Tuuk, IV (1912), p. 481a geeft i. v. ma V:, verkorting van mahâ en soms mâ gespeld", en verg. er ma II (mapatih, mahasti)."In Tamil is $\mathrm{ma}$ de gewone samentrekking van Skr. mahā (Coedès, p. 10).

2 In zijn pasverschenen studie "De inscriptie van Karang Brahi» (Tijdschr. Bat. Gen. LIX, 1921, p. 426-431), welke een repliek bleek van die van Kota Kapoer zonder het slot en 't jaartal, lost Dr. Krom het bhūmi Jā wa te Kota K. aldus op: „Bhūmi Jāwa is dan het gebied, waar de steen staat, dat wil dus zeggen Bangka" (p. 430). Een gedenksteen alléén dus van den Bangka-tocht. 
omtrek van den Diëng; waardoor de zéér vele oud-Maleische woorden in de daargevonden inscripties (vooral Gandasoeli van 769 Çaka, en de ongedateerde - oudere ? - vandaar; A. LAFEBER) hun aanwezigheid op die Oudjav. oorkonden verklaard zouden vinden. Kunnen zelfs deze "Vorsten-slaven" (hulun haji; Diënginscriptie van 731 Çaka) niet vooral koeli's zijn geweest bij den bouw der Diëng-tempels? Zie mijn "Oudheidkundige Opmerkingen», in deze Bijdragen, dl. 74 (1918), p. 141-142, en 147. ${ }^{1}$

Doch is dit bovenstaande voor de periode ca. $650-800 \mathrm{~A}$. D. nog alles min of meer conjectuur, in de $9^{\mathrm{e}}$ eeuw komt er daging van licht door den oudsten Arab. schrijver, IBN CHORDADHBEH, die in circa 846 ons den naam Schalāhiț $=$ Mal. Sělat $=$ òf Singapore òf Bintan òf Karimoen onthult. Hiervoor mag ik herinneren aan wat ik vroeger schreef i. v. "Tochten (Oudste ontdekkings-) tot 1497, in Encycl. v. N. I. IV (1905), p. 370a : „Ook noemt Ibn. Chord. nog "(l'île) .... de Schalâhit» nà *(l'île) de Kilah», d. i. het Sëlat-eiland of Zuid-Malaka nà Këdah of Noord-Malaka." Verg. sindsdien ook Ferrand's Relations de Voyages, I (1913), p. 27, noot 4, die dit "Şalāhiṭ» echter gelijkstelt met "le détroit de Malaka»; m. i. minder juist. De conservatieve Chineezen noemen nog steeds de kota Singapore: Si-lat; evenals ze de kota Batavia altijd nog noemen: Ka-la-pa. ${ }^{2}$

Alleen het eiland Bintan (of Riouw), dat steeds een schuilhoek is geweest voor verdreven Maleiers van Zuid-Malaka, aan den $O$. ingang tot de Selat, en dat in de nationale overleveringen der Sadj. Mell. een zoo veelzeggende rol speelt, kan, naast het eiland van Singapoera, in aanmerking komen voor de gelijkstelling met dit Arab. Schalāhit = Sĕlat; èn voorts het eiland Groot-Karimoen, waarvan wij een kostbaar document bezitten, helaas ongedateerd, slechts door Dr. Brandes naar de foto en papierafdrukken benaderd als kuit de negende, misschien de tiende eeuw van onze jaartelling» (Notulen Bat. Gen. 1887, p. 152); immers bij den W.-ingang van die Sělat, n. l. aan de Noordpunt van Groot-Karimoen (of misschien aan den Z.-W.-kant van Klein-Karimoen?). Hier toch heeft een vroom Indisch Mahājānist in, laat ons zeggen 900 A. D., het bevaren van de Sĕlat met een rotsinscriptie in Sanskrit van ca. 0.3 bij $0.6 \mathrm{M}$. gedocumenteerd, daarbij zelfs als beeld voor den Boeddha zich

1 En zie vooral thans Poerbatjaraka in T. B. G. LIX (1921), p. 416-417!

2 Zie Groeneveldt, Notes (1876), p. 115; noot 1 ; of 2 en dr. (1887), p. 235 noot 2. 
bedienend van een wetenschappelijk-nautischen term (golayantra $=$ Lat. armillarium; een ouderwetsch soort van astrolabium). ${ }^{1}$

Zou dan misschien zelfs niet met Karimoen te vereenzelvigen zijn dat raadselachtige "détroit que les barbares nomment $\mathrm{T}$ che " uit ca. 800 A. D., door Groeneveld in 1896 kort (T'oung Pao, VII, p. 119-120), door PELLIOT in 1904 uitvoerig behandeld? ${ }^{2}$

1 Zie voorts Brandes, l. c. p. 148-152 (over de ontdekking op Zat. 6 A ug. 1887, zie pag. $125-126)$, en de hertoetsing van Brandes' vertaling door Prof. Kern in Notulen B. G. 1888 , p. 155 (thans herdrukt in diens Verspr. Geschr. VII, 1917 , p. 141-142); voor den uitleg van een golayantra verwees Brandes naar Colebrooke's Miscell. Essays (1837), II, p. 315-351. Dr. Krom (naar pers. meded.) acht de inscriptie echter ouder dan Dr. Brandes schatte.

De precieze plek der inscriptie is tot heden niet bekend, en, na de ontdekking in 1887 door drie Engelschen uit Singapore, door geen ernstig onderzoek in loco van Ned. zijde gevolgd! Behalve de literatuur over deze oudheid te „Pasir Pandjang” bij Krom, Voorloopige lijst van oudheden in de Buitenbezittingen (Oudheidk. Verslag 1914, p. 139), kan nog gevoegd: Graafland in Bijdr. Kon. Inst. 5, III (1888), p. 536 noot 2; Zeemansgids O. I. Arcb., II (1900), p. 203; Zeekaart no. 45, Dec. 1902; en Zeemansgids, 2• dr., II (1905), p. 199.

Doch ziehier juist de controverse omtrent de plek. Controleur A. F. P. GraAFLAND in zijn mooie studie t.a.p. (met kaart) zegt: „In de Sělat Kărimon anak ligt op 't eiland Kărimon [ = bịj hem steeds: Groot-Karimoen; Klein-Karimoen noemt hij Kărimon Anak, zic b.v. p. 532, en zijn kaart] een groote steen met inscriftie, blijkbaar afkomstig uit den Hindoetijd"; maar de Zeemansgids in beide drukken spreekt van de "Batoe Bersoerat, bij kamp. Padas”. Noch Graafland's kaart echter, noch de eigen Zeekaart van 1902 kaarteert een kampoeng "Padas"; alleen zet de Zeekaart een "Bt Bersoerat" aan de N. W. helling van den G. Bětina (1350 voet $=405$ M.), vlak aan zee, ten N. O. van een kampoeng "Teloes Timbal” (= Sěmemal bij Graafland??). Maar Graafland zegt duidelijk dat de steen zich bevindt in de "zeer goede bevaarbare" (p. 532) zeestraat tusschen Groot- en Ḱlcin-Karimoen; bovendien bevat dl. II van den Zeemansgids in zijn $3^{\text {on }} \operatorname{druk}(1913)$ en $4^{\text {en }} \operatorname{druk}(1916)$ niets meer over een "Batoe Bersoerat". Ra, ra?

2 N.l. in zijn "Itinéraire par voie de mer" uit 785-805 van Kia Tan (730-805 A. D.), in zijn „Deux itinéraires etc.”, Bull. Éc. fr. d' Extr.-Or. IV (1904), p. 372373 ; voor den tijd, zie p. 131-132; dit, en ook Kia Tan's vastelands-itinerarium (l. c. p. 364-372), is, in waarschijnlijk iets verkorten vorm, opgenomen en daardoor gered in dezelfde Nieuve Annalen der 'T'ang- of Thang-dynastie (618-906 A. D), die ons ók zulke zeldzame gegevens hebben bewaard over Java (Groeneveldt, 1876, p. 13-15; of 1887, p. 138-140).

Dit zee-itinerarium zegt, dat men per schip uit Canton, nà voorbij Pen-t'olang (= Phanrang, Zuid-Cochinchina, $112^{\circ}$ N. B.; Skr. Pāndurañga, Finot; zie 1.c. p. 216) en den berg Kiun-t'ou-nong (='t eiland Condore, Pelliot; met zijn hoogen top van 1954 Eng. voet, dus 595 M.; l. c. p. 217-219) te zijn gezeild: „Puis, après cinq jours de route, on arrive à un détroit que les barbares nomment Tche. Du nord au sud il a cent $l i[1 l i=$ toen ca. 0.4 K.M. $]$. Sur la côte septentrionale, c'est le royaume de Lo-y ue [wel = Ligor; Gerini, 1909]; sur la côte méridionale, c'est le royaume de Fo-che $[=$ Palembang, 
En als dan waar is, dat (zie hiervóór blz. 18, noot 1) het tegenwoordig Mal. sĕlatan $=$ Zuid, een jongere term zou dienen te zijn in het oudere Maleisch, dan mag nu nader gezegd: dat deze afgeleide windstreek-aanduiding zeker reeds in de $9^{\mathrm{e}}$ eeuw A.D. kan hebben bestaan. Maar wat was dan de oudere Mal. term? Nogmaals: was het niet in oud-Malajoe $=$ Djambi, dus zeg in de $7^{\mathrm{e}}$ eeuw, het Mal. kidal $=$ (thans alleen) klinksch»? Immers in 't Kawi en Jav. behalve als kidal, kidal, kedel = «linksch», 6ók als kidoel = Zuid bestaande (verg. V. d. Tuuk, II, 1899, p. 144145; en daar ook: ngidal $=$ "Zuidwaarts gaan»; dùs ook de in ca. 1250 A. D. gestichte Tjaṇdi Kiḍal in Pasoeroean, niet $=$ de «linker-tempel», maar de Zuider-tempel, n.l. Z. van Singasari).

Hoe prachtig klopt ook zoo'n oud-Malajoe'sch kidal $=$ èn «links» èn ‘Zuid», met het gewis ók oud-Malajoe'sch (en later dan weer door de Javanen overgenomen) koelon = èn "naar bovenlands, bovenstrooms» (ka-oeloe-an), èn West! Want in oudMalajoe $=$ Djambi ( + Palembang $)$ liepen en loopen de rivieren van West naar Oost; op Java's (Noord-)kust daarentegen, als voorheen, van Zuid naar Noord. M. a. w.: een oud-Maleisch koelon en kidal $=$ resp. W. en $Z$., is volkomen in orde; een Oudj. koelwan en kidal, kidal, kidoel, Jongjav. koelon en kidoel = resp. W. en $Z$., is schijnbaar dwaasheid (immers $90^{\circ}$ verdraaid; waar het $Z$. en $O$. diende te beteekenen); alleen logisch en historisch te verklaren als termen, die werden overgenomen van oud-Zuidsumatranen. Helaas helpt ons de groote ongedateerde, haast heelemaal oud-Maleische inscriptie op het rotsblok te Gandasoeli, die de 4 windstreken geeft, ten deze geen steek verder; want die heeft voor O. Z. W. N. het Sanskrịt "pūrwwadakșina paccima uttara (Oudj. Oorkonden, ed. Brandes-

Çrī Widjaja, San-fo-tsi]. A l'est du royaume de Fo-che, en allant par eau pendant quatre ou cinq jours, on arrive au royaume de fo-ling [ $=\mathrm{Ka} \cdot \mathrm{ling}$, Kalingga, Midden-Java]; c'est la plus grande des îles du sud. Puis, vers l'ouest, sortant du détroit [nl. Tche; of $\mathrm{Chih}$, naar Groeneveldt's transcriptie, 1896 , p. 119 , en ook Gerini, 1909, p. 776, 814], après trois jours on arrive au royaume de Ko-ko-seng-tche [=??], qui se trouve sur une île séparée à l'angle nord-ouest du Fo-che [dus ergens op Midden-Sumatra]. Les hommes de ce royaume sont pillards et cruels; les navigateurs les craignent [is sengtche soms Mal. djanggi, Oudjav. djěnggi, "neger»?]. Sur la côte septen. trionale, o'est le royaume de Ko-lo $\left[=K_{\breve{e} d a h]}\right.$." (Tekst l. c. p. $372-373$ ).

De vaartijden zijn in dit stuk te klein; maar de koers door de straten Singapore en Malaka is juist! Zie Pelliot opnieuw over dit document in T'oung Pao XIII (1912), p. 451-455, bij zijn besproking vąn Chau Ju-kua. 
Krom, 1913, p. 237, regel 9); waarin immers Skr. dakṣiṇa $=$ èn "rechts» en "Zuid» is, òmdat de diep-religieuze en vastelandsche Hindoes zich vóór alles "oriënteeren» naar de rijzende zon, en hun "rechts-omdraaien» een sacraal-Indische beweging is. Anders dus dan de zeevarende en rivieren-opvarende Maleiers, die linksom draaiden, zooals nu nog de Javanen met hun vingers; voor wie de Zee (laoet) N. lag; het Bovenland en de Riviersprengen (oeloe, hoeloe; hoeloe ajerr), dan wel de oorsprong van den sterksten Moesson-wind (barat), W.; het Linkerhandsche (kidal, kidoel) derhalve ook Z., of later, van Singapore uit gerekend, "zeestraat-waarts» (sělatan). Vrage alleen: hoe is het Mal.-Jav. timoer $=\mathrm{O}$. te verklaren? En hoe het Mal. tënggara, toenggara $=Z$. O. ? ${ }^{1}$

Ten slotte komen in deze periode ook de Kalang's op Java in het spel, minstens sedert 785 Çaka, en vooral vanaf 800 Çaka, in Mataram en Kèdoe. Dat zij krijgsgevangenen kunnen geweest zijn uit de Noorderhelft van het schiereiland Malaka, en het daarbij aansluitende rijk Pegoe (Neder-Birma) van weleer, heb ik nader aangetoond i.v. *Pegon», Encycl. v. N.-I., $2^{\text {en }}$ druk, III (1919).

Oók dit postuleert zeemacht, zee-contact, en 'dùs zee-gevechten, van Midden-Java vóór 900 A. D. met èn $\mathrm{K} e \mathrm{dah}=$ NoordMalaka, èn met Hasìn = Sělat = Zuid-Malaka, oftewel oudSingapore; evengoed als met Çri $\mathbf{i}$ Widjaja= Palembang, en Ma $1 \bar{a}$ joe $=$ Djambi.

\section{B. Singapore-Hasin tusschen ca. 900 en 1200 A. D.}

In dezen tijd beginnen de nevelen op te trekken. We krijgen houvast èn aan de Annalen der $2^{\mathrm{e}}$ Chin. Soeng-dynastie (960-

1 Dr. Adriani verstrekte mij dd. 11 Juli '19 hierover de volgende opmerkingen: "Omtrent het Mal. timoer moet ik je zeggen, dat het woord op zich zelf voor mij duister is. In het Sangireesch en in het Tagalog beteekent het "Zuid”, in het Magindano-sch Zuid-Oost, in 't Bisaja-sch weer: Oost. Het Sangireesch timoeh $\breve{~ h e e f t ~ t o t ~ S a s a h a r a-t e r m ~(z e e-t a a l, ~ g e h e i m e ~ t a a l) ~ b o l ~ a, ~}$ „grijs, grauw". Indien dit woord gelijkwaardig is met timoeh een vervang-term dan zou het de zee kunnen aanduiden en daarmee zou ook timoehĕ, timoer, timog enz. (Brandes' Dissertatie [1881] blz. 45) verklaard zijn. Denk maar aan Jav. lor, „zee" (uit laoeḍ); koelon, "West”, uit kĕeoloe-an, „naar 't Bovenland", Mal. daja, dat oorspronkelijk ook ,binnenland" beteekent (Makass. raja, Boeg. radja). Ook in 'b Minalyassisch is timoe „Zuid, Zuidenwind"; in 't Boeg. is het weer "Oost" en "Oostenwind", d. i. "zeewind". Het Makassaarsch heeft timoro', "Oostenwind, zeewind", en timboro', "Zuid", te Bantaeng weer "Oost"... Toenggara of tĕnggara, „Zuid-Oost", is mij duister. De Sangireezen, die 16 benamingen van windstreken hebben, kennen 't niet. $\bullet$ 
1279 A. D.), èn aan de oorkonden in steen of koper dér Oost-Jav. Vorsten, voor alvan ERLANGGA (geboren 913 Çaka $=991$ A. D.; regeert, al vechtende, 1019 - na of in 1042).

Allereerst een vraag, die reeds eventjes hiervóór op blz. 43 werd gesuggereerd: van wààr deze zonderlinge Vorstennaam, de «Water-slurper»? Was hij soms ostentatief medelid van een Oudjavaansch matigheids-genootschap? - Zijn in 941 Çaka aangenomen Koningsnaam, waarin dat ongewone, zuiver-Indonesische, doch met Sanskrit-genitief geconstrueerde *Air-langga * of *Erlangga» zoo met opzet gekozen werd, en dan ook in den mond der nazaten uitsluitend bleef leven, was natuurlijk zuiver-symbolisch; heenwijzend naar iets, dat zijn .tijdgenooten maar al te goed begrepen. Kan ER-LANGGA zijn kronings-titel in 1019 A. D. zóó gekozen hebben, omdat hij toen de andere, vijandelijke, "wateren " (= water-beheerschers) had "opgeslorpt ; ook al moest hij met name tegen Woerawari weer vechten in 954 Çaka $=1032$ A. D. ? ${ }^{1}$

In deze periode bestaat $\mathrm{Has}$ in als een aan Java vijandelijk en bijna gewis Maleisch land. Want een verloren gegane Oostjavaansche oorkonde op koper, in den Madjapahit-tijd gecopieerd op steen, in 1832 uit "de ruïnen van Modjopahit» overgebracht naar den Residentstuin te Soerabaja ${ }^{2}$, en in ca. 1876 naar het 't Museum te Batavia (D. 16), uit 956 Çaka = 1034 A. D. - d. i. dus 4 jaar na de groote Tanjore-inscriptie, met de verheerlijking der scheeps- en zegetochten van den. Tamil-Vorst Rājendracola I naar Kedah, Palembang enz. - memoreert "de overwinning van Airlangga op een vorst van Hasin... Dat Hasin doet denken aan de Maleijers, die in een pijagèm van Bantam (z. Brieven over het Lampongsch [Tijdschr. Bat. Gen. XIX, 1870, p. 393]) wong asin (ziltelieden, zeelieden .) 'genoemd worden»; aldus V. d. Tuuk reeds in Notulen Bat. Gen. 1876, p. 27. ${ }^{3}$ Met een niet-verklaard, opmerkelijk verschil, schreef Brandes in 1887 (Groeneveldt's Catalogus Archeol. verzam. Batavia, p. 378), dat deze oorkonde 1 Blijkens r. 23-25 der Calcutta-inscriptie van 963 Ç ; Kern, 1917, p. 105, 109.

2 Zie toch Netscher in T. B. G. II (1854), p. IX-X; en verg. den Inventaris der Hindoe-oudheden, II, in Rapp Oudh. Dienst 1915 (1918), p. 164.

3 De letterlijke woorden uit 1870 in het T. B. G. waarnaar Van der Tuuk in 1876 verwees, luiden (dd. Tarabanggi 18 April 1869):

„Ik vind in een pijagĕm van Bantĕn 'steeds wong ĕntjik, en vind dit opmerkelijk, daar het weder bewijst, dat wong Malajoe een scheldnaam was. Vreemde zeevarende natiën worden in denzelfden pijagěm wong masin genoemd. Ik dacht eerst aan 't Mal. asing, maar meermalen vind ik het, en steeds is het met een $n$ gespeld; vandaar dat ik het nu bepaald van asin afleid." 
gegeven was aan lieden van de desa Baroe, omdat deze «hem trouw zijn gebleven op een hachelijk oogenblik gedurende den oorlog met den vorst van Mahasin», waarbij Brandes verwijst naar V. d. Tuuk in de Notulen van 1876. Oók Brandes' eigen transscriptie van deze oorkonde (Oudjav. Oorkonden, ed. BrandesKrom, 1913, p. 129) heeft intusschen tot tweemaal toe: Hasin, géén "Mahasin» (regel 5-6: musunhnira ikana i hasin; r. 7 : ratu $i$ hasin). Hoe is dit door Brandes met opzet ònverklaard gelaten raadseltje te verklaren? Alléén zoo: het jaar te voren (1886) was als Bijlage I in de Notulen Bat. Gen. afgedrukt die reeds hiervóór (blz. 9 noot) genoemde baanbrekende nota van den Sinoloog S. BEAL uit 1883 over I-tsing's landenlijst uit ca. 692 , „The situation of the country called "Shi-li-fo-shai»"; en dààrin had Brandes ook gelezen die gewichtige opsomming door Beal van I-tsing's "islands of the Southern sea»; aldus:

"Reckoning from the west there are the countries (islands) of Po-lu-sse, Mo-lo-yau, (now called Shi-li-fo-shai), next Mo-ho-sin, Ho-ling, Tan-tan,» etc. (p. I).

Ik durf pertinent zeggen: aan dit "Mo-ho-sin» van 1886 moet Brandes hebben gedacht, toen hij het "Hasin» der oorkonde, het “Hasin» ook van V. d. Tuuk, in 1887 ten tooneele voerde - met zijn welbekenden geheimzinnigen régisseurs-glimlach! - als: Mahasin. Lees duidelijker: Ma-Hasin of Mā-hasin $=$ "Groot-Hasin».

Dit is dus een merkwaardige en voor mijzelf geheel ònverwachte bevestiging van wat hiervóór, blz. 68, over I-tsing's Mo-ho$\mathrm{h}$ sin uit Takakusu's uitgave reeds werd gezegd. Van der Tuuk dacht bij Hasin aan "Maleijers»; Brandes daarbij tevens aan I-tsing, al noemde hij hem niet, en al kon hij Takakusu's editie van 1896 nog niet kennen; waar het trouwens tot "Mahâsin" werd verhaspeld, en vragenderwijs gezocht, maar ten onrechte, in "the present Bandjarmasin" (p. XXXIX; XLVII), ${ }^{1}$ of, op de kaart vóóraan, met wat minder aarzeling, in het eiland Billiton. ${ }^{2}$

1 Verg. hiermee Pelliot's noot 2 op p. 325 in zijn Deux itinéraires etc. (1904), die Mo-ho-sin ook denkt in Borneo (,je ne vois pas pourquoi on ne pourrait songer à Bornéo"), anderzijds verwijst naar Veth's Java, 2*n druk, I (1896), p. 49-50, waar bovenstaand gegeven van Brandes uit 1887 (zonder vermelding der bron) verwerkt werd. Door dit defect in Veth liep Pelliot er in, meenende dat dit "Mahasin" vermeld stond in Prof. Kern's studie van 1885 in Bijdragen Kon. Inst. 4, X over Erlangga's Sanskrit-inseriptie te Calcutta (welke studie hem weer niet ter beschikking was).

"Hier, op Takakusu's kaart, staat toch bij „Billiton" bijgeschreven in rood: "(This may be Matâsin from its position)". - Wat bij 't eiland Bangka aldaar 
Ha s in staat dus vast in ca. 1030 A. D. als een Maleisch land buiten Java, waarvan Erlangga geleden, en. waarop hij zich vóór 1034 A. D. gewroken had. ${ }^{1}$ Mijns inziens is dit Hasin $=$ Māha sin, Mahasin niets anders dan Tāsik = Těmāsik (Oudjav. Toemasik) $=\ldots$... weder óók Samoedra!

Want - en dit zéér belangrijke gegeven danken we aan FERRAND in zijn opstel van 1917 in 't Journal Asiatique, "La plus ancienne mention du nom de l'île de Sumatra» (I, p. 331-335) —, in het Chin. gegeven uit 1017 van de Annalen der (2) Soeng-dynastie:

«In 1017 the king Ha-ch'i-su-wu-ch'a-p'u-mi sent envoys with»... etc. (Groen., p. 65; of $2^{\mathrm{e}}$ ed., p. 190),

ligt besloten een Hadji Sumutra-bhūmi; volgens Ferrand een Vorst (adji, hadji) van Sumatra-land; volgens mij echter een Vorst van Samoedra-land, d. i. "Zee»-land, d. i. Tāsik-land, Témāsik, Toemāsik, oftewel het Singapore-eiland. En is deze laatste opvatting juist, dan volgt daaruit weer noodwendig, dat het latere, 13-eeuwsche Samoedra, in ca. 1275 op Atjeh's Oostkust te constateeren, immers in 1292 blijkens Marco Polo nog niet Mohammedaansch (zooals wèl Perlak), niet primair is geweest met zijn naam-aanneming in onzen Archipel, doch nadeed wat Toemasik-Hasin in een variant-naam reeds 3 eeuwen vroeger had vertoond aan Malaya's Zuidpunt.

Scherp te onderscheiden m. i. van dit Hasin (= Tasik = antiekSamudra) valt echter het Wurawari(= Ganggāyu), welks naam het eerst gedocumenteerd is voor 928 Çaka $=\mathbf{1 0 0 6}$ A. D., terwijl de tweede ca. 1612 voorkomt in Verhaal I der Sadjarah Měl. (zie hiervóór blz. 43). Has in was m. i. de eiland-stad en staat, die overeenkomt met het tegenwoordige Singapore; Wuraw a ri echter de vastelands- en rivier-staat aan den benedenloop der Soengai Djohor, van de kuala Johor af tot voorbij Johor Lama.

in rood vermeld staat: "(This Isle is never mentioned by special name in chinese history)" is onjuist; in de Ying-yai Shêng-lan van 1416 komt "the Strait of Banka" (P'ang-ka-bun) voor, zie Groeneveldt, Notes 1876, p. 73, of 1887 , p. 197; en op de Chin. kaart uit ongeveer dienzelfden tijd, gepubliceerd door Phillips in Journal China Branch R. A. S. for 1886 (Shanghai, 1887), staat het als een groot eiland met het bijschrift $\mathrm{P}^{\prime} \mathrm{eng}-\mathrm{kia}-\mathrm{shan}$ of „Bangka-bergland" (l. c. p. 40 sub $\mathrm{n}^{\circ} 32$ ).

1 Het jaartal van Erlangga's zoogenaamd oudste inscriptie, tot nog toe gelezen "943" (Oudjav. Oorkonden, ed. Brandes-Krom, 1913, p. 120), acht Dr. Krom ten rechte: 953 Çaka (=1031 A. D.); zie toch T. B. G. LIX (1921), p. 423 noot. De oudste wordt dan die van 945 Ç. (Cohen Stuart, Kawi Oorkonden, 1875; V.). 
Bekijken wé dan nog eens de groote Tanjore-inscriptie van 1030 A. D. ${ }^{1}$, die door de mooie studie van CoEDÈs in een geheel nieuw licht is komen te staan, dan meen ik te mogen opmerken, dat van de daar genoemde en met een korte omschrijving getypeerde landsnamen het "Māyiruḍingam entouré par la mer profonde (comme par) un fossé» (1. c. p. 5), verreweg het meest doet denken aan het eiland van Singapore; het volgt daar na 3 landsnamen, welke alle drie thans op Sumatra's Oostkust met vastheid te herkennen zijn, en wel - na Kaḍa a ram = Kedah als $\mathrm{n}^{\circ} .1$ - aldus in de rij: $\mathrm{n}^{\circ} .2$ Çrīvijayam $=$ Palembang; nº 3 Paṇnai = Mal.-Jav.-Tamil Panai, Pane ${ }^{2}$, aan den mond der Panai-Baroemoen-rivier; $\mathrm{n}^{\circ}$. 4 Malaiy ūr $=$ Djambi; $\mathrm{n}^{\circ}$. 5 Māyiruḍingam. Het zoude dan, afgezien van het grootmachtige KÆ̌dah in den aanhef, de éérste landsnaam op het Maleische Schiereiland wezen dàt vermeld werd na de 3 Oostsumatraansche; het epitheton zou óók hier treffend-juist zijn, evenals bij de andere, voorzoover we die reeds kunnen controleeren. Over de verklaring welke Coedès voor dezen naam, "Groot-Yirudingam" = Groot- Ji-lo-t'ing bij Chao Ju-kua in 1225 A. D., heeft voorgesteld (1. c. p. 10-11), zal zoo dadelijk blijken dat deze gelijkstelling behouden kan blijven; maar dat we met dit Chin Ji-lo-t'ing terecht komen in de onmiddellijke buurt van Singapore, terwijl Coedès de identificatie van dien Chin. landsnaam als geheel twijfelachtig beschouwde.

En wat volgt dan in die inscriptie dadelijk weer nà Māyiru-

1 In Ferrand's Relations de Voyages enz. II (1914), p. 645 staat door een drukfout: „L'inscription de Tanjore (1050)." Ook leze men daar op regel 11 v. o. voor de regeerjaren van Rājendracola I niet "1031 [drukfout voor 1013] à 1044", maar: 1012--1042 (zie toch Coedès, p. 4). Ferrand geeft daar den nu verouderden uitleg van Kaḍāram (p. 616, noot 8).

2 Naar pers. meded. van Prof. van Ronkel is Tamil paṇnai $=$ „bouwland, bewaterde akker, rijstveld"; dit zou dus zeer goed kunnen passen voor de naamgeving van deze streek door Tamil's, welke dan in het Oudjav. Pane van 1365 A. D. (Nāgarakĕrtägama 13:1), en in het tegenwoordige Mal. P anai, vulgo $\mathrm{Panei}$, als landsnaam zou zijn blijven voortleven. Het epitheton in de inscriptie: „Paṇnai arrosé par la rivière” zou dan weer typeerend ook zijn.

Een gansch ander Oudjav. en Jav. pane = ,aarden pot met wijde opening" (V. d. Tuuk, IV, 1912, p. 15b, met als variant op p. 39b: panaj; en RoordaVreede, 1901, II, p. 184a) is eveneens van het Tamil. Dit pānai $=$ "groote pot" komt echter volgens Dr. van Ronkel juist niet in het Mal. voor, zie Tijdschr. Bat. Gen. dl. 46 (1903), p. 545; en komt daarom voor den landsnaam niet in aanmerking. 
dingam? Dit als $n^{\circ}$. 6: "Il a ñgāçogam indompté (dans) de terribles batailles», waaruit reeds FERRAND in 1914 (Relations de voyages, II, p. 647, noot 1 ), het vertamiliseerde $i$-Langkasuka terecht had gebracht; terwijl Coedès in zijne studie bovendien opmerkt: 'L' $i$ initial ne fait pas difficulté, le tamoul ajoutant souvant un $i$ au début des mots étrangers commençant par une linguale ou une liquide» (p. 11): Maar wààr had dit Langkasoeka gelegen? Deze vraag wist niemand goed te beantwoorden. Welnu, na het bovenstaande komt als vanzelf de vraag op de lippen: zou Lañ gā çoga m op deze Tamil-inscriptie van $1030 \mathrm{~A}$. D. wel iets anders zijn dan.... Wurawari uit 1006 èn 1032 A. D., of Ganggāyu in ca. 1612? Deze vraag zal zoo dadelijk nader worden behandeld, en bevestigend worden beantwoord.

Voorts, ligt het niet voor de hand, dat een Vorst in zijn overwinnings-bulletin éérst noemt het àllergewichtigste, dan het zèèr gewichțige, en zoo afdalend, om bij het slot van zijn lijst weer rhythmisch te stijgen tot een pakkend slot; volgens het welbekende recept immers voor den redenaar: de aanhef en 't slot moeten aangrijpend wezen, de middenmoot mag middelmatig zijn? Als we dan weten, dat er in 1030 een Hasin en een Wurawari als staten bestonden op - naar hooge waarschijnlijkheid - de Zuidpunt van het Maleische Schiereiland, die resp. vóór 1034 en in 954 Çaka $=1032 \mathrm{~A}$. D. hun aanvallen overbrachten op Erlangga's Oost-Java, dan vinden wij de 13 Staten in Rājendracola's manifest te Tanjore opgesomd in deze reëelrhetorische, ten deele óók geografische, volgorde:

[1=14; zie slot:] 1. Küdah (Kaḍāram), het Geweldige bij uitstek, met name te land (door o. a. olifanten);

[2-4; op Sumatra:] 2. Palembang (Çrī Vijayam), het Rijke emporium ${ }^{1}$; 3. Pane, Panai (Paṇnai), de Rivierstad; 4. Djambi (Malaiy ūr), het Antieke;

[5-8; op het Maleische Schiereiland:] 5. Hasin, Māhasin (MāYirudinga m), de Zeestad; 6. Woerawari = Ganggajoe $=$ Lĕngkasoeka (I-La ṅgāçog a m), het Onoverwonnene; 7.Pahang?? of veeleer Fenang (M $\bar{a}-\mathrm{P}$ pa p pāl a m), de Waterstad ("défendu par d'abondantes eaux profondes»); 8. òf

1 Coedès (p. 5, noot 1) maakt opmerkzaam, dat een deel der epitheta ornantia, die, in Hultsch' vertaling der inscriptie van 1891, alle worden toegekend aan Kaḍāram, wellicht kunnen slaan op Çrīvijayam. 
Dinding, dan wel Bruas, in Perak (M evilimbang a m), het Ommuurde («défendu par de belles murailles»; verg. hiervóór blz. 42, Verhaal 1 der Sadjarah Mël.); òf misschien ook het eveneens antieke Kĕlang in Sellangor;

[9; op Tjampa's Zuidkust:] 9. Phanrang, Pänduranga? (VạiaiP p and u r u, waarin - naar vriendelijke mededeeling van Prof. VAN RONKEL - Tamil valai = "vesting , is), het deels nog Wilde ('possédant (à la fois) des terres cultivées(?) et des terres incultes»);

[10-11; terug op het Noorden van het Mal. Schiereiland:] 10. Ptolemaeus' Tákóla $=$ Takkola van de Milindapañha (d. i. "Menander-Dialogen»; ca. 400 A. D.) = Takuwa Pa van thans (Gerini, 1909), Mal. Takopa; op de Westkust, $8^{\circ} 52^{\prime}$ N.Br. (Talai-T takkolam; waarin Tamil talai $=$ "hoofd, begin», Coedès) ${ }^{1} ; 11$. Támbralingga ("Lingga

1 Talai-Ttakkolam zou dan zelfs in 1030 A. D. iets als „Begin van't Maleische Schiereiland" (van 't Noorden uit gerekend; van Voorindisch zeevaarders-standpunt dus) hebben beteekend, waarbij de eerwaardige oude plaatsnaam werd toegepast op de heele Chersonesus. Iets dergelijks dus weer als de in ca. 1345 door Ibn Batoeta gebezigde term Mul Djāwa = „Java-Begin", versta: Noord-Sumatra, met de hoofdstad Qāqula, waar een Hindoe.Vorst (A dityawarman! van vóór 1343-na 1375) toen regeerde; zie mijn art. „Tochten (Oudste ontdekkings-) tot 1497" in Encycl. v. N. I. IV (1905), p. 381b, waarin alleen de verwijzing naar de inscriptie van Pagarroejoeng moet geschrapt, als ten onrechte gebaseerd op de oude foutieve lezing van Friederich in Verh. Bat. Gen. XXVI (1857), 1e stuk, p. 32 en 69-70. Verg. voorts de plaatsen bij Ferrand, Relations de Voyages, II (1911), p. 427, 445, 446 noot 1, 450, alle uit Ibn Batoeta; en een oudere plaats, uit ca. 1300, bij den'Perzischen historicus Wașșāf, die van $\mathrm{M} \overline{\mathrm{u}} \mathrm{l}$ Tj $\mathrm{j}$ āwa spreekt, p. 359.

Waar Qāqula (Arab. „cardamom”, Amomum Cardamomum Willd.) echter ten -rechte mede gelijkgesteld moet worden, blijft onopgelost; Van der Lith (Merveilles de l'Inde, 1883-86, p. 240) zag er "Angkola” in; doch Pelliot in T'oung Pao, XIII (1912), p. 455 zoekt Kia Tan's Ko-ku-lo uit ca. 800, en daarmee ook Ibn Batoeta's Qāqula, op de Westkust van 't Maleische Schiereiland. De woorden van Kia Tan (zie reeds hiervóór blz. 70 noot 2, slot) zijn: "A l'ouest du [royaume de] $\mathrm{Ko}-\mathrm{lo}\left[=K_{\breve{e}} d a h\right]$, c'est le royaume de $\mathrm{Ko} \cdot \mathrm{k} \cap \mathrm{u}-\mathrm{lo}$ (Pelliot, Deux itinéraires etc. 1904, p. 373). Dit zou toch op zich zelf prachtig heenwijzen naar een later $\mathrm{M} \overline{\mathrm{u}} \mathrm{l}(\mathrm{a}) \mathrm{Dj} \mathrm{a}$ w a $=$ Noord-Sumatra, zeg "Java minor" in den trant van Marco Polo in 1292. Aan den anderen kant herinnert weer Coedès (p. 15, noot 5), dat juist Pāli takkolam, Singhaleesch takul $\approx$ cardamom is. Doch zie dan óók weder het Javādhideva(?) in de Tjampa-inscriptie van 1228 Çaka = 1306 A. D., even verderop hier (blz. 82, met noot 1) nader behandeld. Alles pleit m. i. er ten slotte voor, om Müla Djāwa voor Minangkabau te houden, Java prior. Verg. ó́k Oudj. karkolaka = kakkolaka ( $=$ "Kakola-product»!) = èn cardamom èn kamfer (v. d. Tuuk, II, 76b, 130b, 291a). 
van koper») $=$ òf Chaiya, òf Bandon, òf - en m. i. verreweg méést waarschijnlijk - Ligor (Lakon, Nagor, Nakon, d. i. alles Nagara; waartegen dan "Ligor" juist corruptie zou kunnen zijn van het oudere "Lingga» ${ }^{1}$; het Lo-yue van Kia Tan's Zee-itinerarium uit ca. 800 A. D., zie hiervóór blz. 70 noot 2 ), dus alle 3 op de Oostkust, resp. $9^{\circ} 20^{\prime}$, $9^{\circ} 5^{\prime}$ en $8^{\circ} 22^{\prime}$ N.Br. (Mā-Damālingam, Coedès, p. 1518 en 32-33; alwaar hij een Boeddhistische inscriptie van "Jaiya» = Chaiya voor het eerst publiceert uit 4332 Kaliyuga $=1230$. A. D., gegeven door Çrī Dharmarāja, Vorst van "Tāmbralinga»).

Het éérste, Ptolemaeus' emporium T'c\%ulc: dus uit ca. 150 A. D. (VII, 2: 5; VIII, $27: 3$ ), in deze Tanjore-inscriptie van $1030 \mathrm{~A}$. D., omschreven wordende als: "loué par de grands hommes (versés dans) les sciences» Coedès, p. 5); wat, via de Milindapañha der $5^{\ominus}$ eeuw A. D. en den daarin geëerden Baktrischen Vorst Menander, alias "Milinda» (ca. 155 vóór Chr.), gewis niet enkel naar Voorindiëzelf, maar óók naar het land der Yawana's of «Ioniërs» = Grieken wijst. ${ }^{2}$

- Het twééde, m. i. niets anders dan Ligor $=\mathrm{Lo-yue}$ (ca. 800 A. D.) = Lingga, zeg: "Çiwa's Stede»; later Boeddhistisch geworden, en "de Stad» (Nagara) of Hoofdstad van Boeddha geworden, $\mathrm{D}$ h a r $\mathrm{m}$ m a n a g a $\mathrm{r}$ (Nāgarakrětāgama van 1365 A. D.; $15: 1)$, alias Nagara Çrī

1 Het zeggen in Gerini's Researches (1909), p. 109: „Nagara, pronounced in Siāmese Nakhōn and corruptedly Lakhön, out of which the Malays and Europeans have made Ligor," schijnt mij toch in zijn tweede helft onaannemelijk toe; hoewel niet verbeterd in de omvangrijke Addenda and Corrigenda (p. 740835). De Port.vorm der $16^{\mathrm{e}}$ eeuw is: Lugor (o. a. Barros, Da Asia, I, 1 ${ }^{\circ}$ dr. 1552, Lib. IX, cap. 1; en II, $1^{\mathrm{e}} \mathrm{dr}$. 1553, Lib. VI, cap. 1); de Mal. in Verhaal 31 der Sadjarah Malajoe van ca. 1612: Ligoer, Legoer. Vrage: zit in den uitgang or van Ligor niet een Drawidisch $\overline{\mathrm{u}} \mathrm{r}={ }_{n}$ stad" verborgen; dus = Ling g-ū $\mathrm{r}$ ? , 2 Winternitz in zijn Geschichte der indischen Litteratur, II, 1 (1913), p. 140141 sehat den ouderdom der oudste deelen van de Milindapañha (n l. Boek I zeer ten deele, II-III geheel) op „ungefähr mit dem Beginn unserer Zeitrechnung zusammenfallen(d)", terwijl Garbe in 1903 deze op "wahrscheinlich im zweiten 'Jahrhundert n. Chr. entstanden" achtte. Boek IV-VII moeten nà ca. 400 A. D. zijn toegevoegd (p. 141-142). De aanhaling van "Takkola" staat in Boek VI:21; zie de vertaling door Rhys Davids, in The Sacred Books of the East, dl. II ( = dl. 36), 1894, p. 269 („The questions of King Milinda"). Noot 2 op p. 141 bij Winternitz moet echter verbeterd worden naar Pelliot in Journ. Asiat. 1914 (2), p. 382, noot 1. 
Dharmarādja (924 A. D.; Gerini 1909, p. 107) - dus in den trant van het oudere "Çrī Widjaja»= Palembang, en het véél jongere ( $15^{\circ}$ eeuwsche?) *Siak Sri Indrapoera $=$ «Si y a k" in 1365 A. D. (Nāg. 13:1); àlles uithang-borden van politieke macht, genre-Gross Berlin, of Groot-Nederland, of Great(er) Britain! —; hier in de Tanjore-inscriptie van $1030 \mathrm{~A}$. D. omschreven wordende als "intrépide dans les grands et terribles combats» (Coedès, p. 5).

[12-13; ten Z.W. en W.Z.W. van Takkōla-Ligor :] 12. Groot-Atjeh, Lamoeri (I-Lāmurideçam), "dont la terrible force [o, Atjeh-oorlogen, 1872-1905!] fut vaincue par une violente (attaque)»; en 13. de Nikobaren (Mā-Ṇakkavāram), deze eilanden van naaktloopende wilden idyllisch beschreven als «dont les jardins de fleurs (ressemblaient) à la ceinture (de la nymphe) de la région méridionale»;

èn — Ik, Rājendracola I, Koning bij de Gratie der Goden (sinds 1012 A. D.), Herzegge - :

[14 = 1; Alpha et Omega:] Kĕdah (Kaḍāram), het Geweldige (te land), beschermd door de zee.

Zou men soms willen ontkennen dat er stijl zit, en methode, en superieure geestes-kwaliteit in dit Koninklijke Manifest van bijna 9 eeuwen her? Het is niet alléén overwinnings-gebral; hier is o Rostand! - ook panache.

Zooals men reeds gezien heeft, is hierboven getracht de oplossing te geven van lands- of stede-namen, die bij Coedès in 't midden waren gelaten (p. 15): Mevilimbangam en Vaḷaippandūru; werd van 3 staten de ligging elders gezocht, dan bij Coedès: Māyiruḍingam, Il ańgāçogam, en Māppappạ̄am; en werd bij 2 zéér oude Staten, Talaittakkolam en Māda$\mathrm{m} \overline{\mathrm{a}} \mathrm{l}$ i ṅ g a m, de identifieering ovẹrgenomen, die voor den eersten Staat rechtstreeks, en voor den tweeden na de recente vondst van Coedès zijdelings, door Gerini in zijn verwonderlijk-slecht en verwonderlijk.goed boek van 1909, de veelal rare en deels rake "Researches on Ptolemy's geography of Eastern Asia», wordt aangewezen (o. c. p. 86-87; en p. 107-109). Dat daarbij de poging van Ferrand in Journal Asiat. 1919, II, p. 178-186,

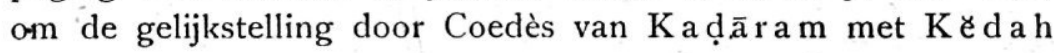


te loochenen ${ }^{1}$, als niet doeltreffend voorbij moest worden gegaan, hoeft slechts met een enkel woord aangestipt; wij mogen zeker van Coedès de afdoende weerlegging ten deze contra Ferrand tegemoet zien.

De 3 eigen afwijkingen moeten nu nader worden verdedigd; de 2 oplossingen allereerst toegelicht.

Vaḷaippandūṛu ("Pāṇdura-veste») = Skr. Pāṇduranga (var. Pāṇdurānga) $=$ Phanrang van thans, dunkt mij, na Finot's artikel "Pāṇdurañga" in het Album-Kern (1903), p. 381-389, en den vermeerderden herdruk daarvan in Bulletin Ec. fr. d'Ex.Or. III (1903), p. 630_648 als "Notes d'épigraphie, V》 nauwelijks aan twijfel onderhevig. Deze plek op Tjampa's zuidelijk uiteinde, waar reeds in 709 Çaka $=787 \mathrm{~A}$. D. een Çiwaïtische tempel in brand werd gestoken door legers uit «Java» - d. i. òf Mẹ̣angMataram, òf (en veel meer waarschijnlijk) Çrīwidjaja-Palembang -, waar in de buurt het Mal. woord maka-poen ("voorts") 4 maal

' In zijn kritische bespreking van Coedès' studie "Le Royaume de Çrīvijaya", l. c. p. 149--200. In zijn iets later afgedrukt "Appendice I, Kolo et Kalah" (l. o. p. 214-233), tot zijn vervolg-studie ,Le K'ouen-Louen et les anciennes navigations interocéaniques dans les mers du Sud", wil Ferrand 3 haast gelijkluidende en niet zeer ver vaneen liggende plekken óók historisch scherp van elkaar als oude havens onderscheiden: 1. Arab. Karā = thans Kra, de Kralandengte, $10^{\circ} 30^{\prime} \mathrm{N}$. Br.: $2^{\circ}$. Kada thans de 2 eilandjes P. Kra, dicht bij den vasten wal, ten O. der Zuidpunt van P. Pinang (Penang), $5^{\circ} 15^{\prime} \mathrm{N}$. B.; alle dus op dezelfde Westkust van Noord-Malaya (l. c. p. 232 , r. 12 v. o. stant door een drukfout $33^{\circ} 34^{\prime}$ voor $5^{\circ} 34^{\prime}$ ).

Gerini, die nog niet van de door Coedès in 1918 het eerst aan 't licht gebrachte inscriptie van Chaiya uit 1230 A. D. kon afweten, had het Chin. Tan-ma-ling van Chau Ju-kua incidenteel gezocht bij Tanjung Tĕmbèling, aan den $\mathrm{N}$. hoek der monding van de $\mathrm{S}$. Kuantan, $3^{\circ} 48^{\prime} \mathrm{N}$. B. ter Oostkust (Journ. R. As. Soc. 1905, p. 497-498); terwijl het landschap Tĕmbĕling dieper het laud inligt, alwaar de S. Tĕmběling stroomt, die samen met de S. Jelai (ons Djělai) de S. Pahang vormt, welke ca. 17' ten Z. der S. Kwantan in de Zuidehineesche Zee valt. Aan dat landschap Tĕmbĕling had Pelliot in 1901 gedacht; verg. Coedès, l. c. p. 16. Mijne opvatting van Mādamālingam = Ligor-Lakhon (en niet òf Chaiya ò Bandon, waar Coedès toe geneigd is, l. c. p. 17-18), is dus zoo te zeggen Gerini's gegeven uit 1909 over Nagara Çrī Dharmarāja, geënt op den Tambraling ga-Çrī Dhar-^ marāja-passus van de Chaiya-inscriptie bij Coedès. Hirth \& Rockhill hadden zich in hun uitgaaf van Chau Ju-kua (1912), p. 66-68, gehouden aan Gerini's conjectuur van 1905 , die inderdaad een heele stap vooruit was, hoewel Gerini zelf in zijn boek van 1909 (p. 601 noot, 626, 825-826) weer was gaan aarzelen tusschen die kaap en het door Pelliot aangewezen landschap met rivier (bij Hirth en Rockhill p. 68, r. 1 leze men: inland district, in plaats van: island district). Over Chau Ju-kua's tekst nit 1225 A. D. zie hierna blz. 92--93, en C.

Dl. 77 
voorkomt bij een opsomming door den Tjampa-vorst Djaja Hariwarman I (1145-ca. 1163) van zijne veroveringen buitenslands op een inscriptie van 1092 Çaka, en welks beheerscher Djaja Singhawarman III (? - 1307) in een inscriptie van 1228 Çaka $=1306$ A. D. gezegd wordt èn eene konings-dochter van "Javādhideva" (= Minangkabau?) als éérste vorstin (Paramecvarì) gehuwd te hebben, èn eene konings-dochter uit "Yavādhipa» (= Fava-proper) gekomen, genaamd "koningin Tapasī» (vyā Tapasī), - deze plek ligt zóó voor de hand in 1030 A. D. alreeds, dat er moeilijk een bevredigender oplossing gevonden zou kunnen worden. ${ }^{1}$

Rājendracola's vloot heeft dan, na Straat Malaka te zijn doorgeroeid en doorgezeild, als een Klingsche "Great Fleet», een smaldeel vermoedelijk afgezonden, om, aan de Noordzijde van

1 Altijd, indien het verschil in slot-klinker $u$ en $a$ (Pandūṛu of Pānḍura) geen onoverkomelijk bezwaar is; iets wat Tamil-kenners mogen beoordeelen. -

Voor de 3 bovenvermelde historische gegevens, zie Finot in Bulletin l. c. p. 636, met noot 3 ; p. 639, met noot 5 ; en p. 641 , met noot 1 . En verg. de historische vervolg-studie van G. Maspero, "Le royaume de Champa", in T'oung Pao, XI (1910), p. 559, en XII (1911), p. 296-303, en p. 479. De conjectuur Ja vādhideva = Minangkabau (?), is van mijzelven; zij sluit historisch zéér aannemelijk aan bij de Pamalajoe-expeditie van Vorst Kĕrtanagara te Toemapĕl gedurende de jaren 1275-1293 A. D., alsmede met hetgeen hiervóór (blz. 78 noot) over het tegen ca. 1300 A. D. in Perz. en Arab. bronnen opkomende Moel(a) Djawa $=$ Noord-Sumatra $=$ Minangkabau, en Marco Polo's Java minor van 1292, werd opgemerkt; d.i. het Boeddhistische Java Prior (of Minangkabau) van ca. 1300 , met Vorst Mau liw a rm m a dew a der inscriptie van 1208 Çaka= 1286 A. D. te Soengai Lansat aan de boven-Batang Hari in het landschap "Dharmmäçraya" = Sigoentoer, door Dr. Krom behandeld in Versl. en Meded. Kon. Ak., afd. Letterk, 5, II (1916), p. 306-339. Evenwel: volgens Aymonier (Bulletin Comm. Archéol. Indo-Chine, 1911, p. 15) staat er niet Ja vā dh ide va, maar: Devādideva, welke "singulière expression" hij dan beproeft terug te brengen (p. 16-17) tot den Vorst van Tongkin, wiens dochter het was.

Dat de Koningin „Tapasi”" uit Java-proper in de T.jampa-inseriptie van 1306 A. D., òf een zuster òf een dochter van Vorst Kĕrtanagara van Toemapĕl (regeert 1268- $\dagger$ 1292) geweest is, heeft Dr. Krom reeds aangetoond in Tijdschr. Bat. Gen. LVI (1914), p. 318-320. „Tāpasi” (sic), beteekent: La Pénitente (Aymonier, 1911, l.c. p. 17).

De 3 plaatsen, waar bovengenoemde Tjampa-inscripties van 709, 1092, en 1228 Çaka gevonden werden, zijn resp.: Da Trang alias Yang Tikuh (W. van Phanrang); Po Nagar (bij Nhatrang, $1^{\circ}$ Noord van Phanrang), en Po Sah (W. Z. W. van Phanrang); zie de kaarten bij Parmentier, Inventaire descr. des monuments cams de l'Annam (1909). Aan het (vermeerderde en verbeterde) opstel van Finot in Bulletin Ec. fr. d'Ex.-Or. III (1903), had Pelliot een Naschrift toegevoegd: "Textes chinois sur Pāṇdurañga", p. 649-654. Pent'o-lang of Pin-t'ong-long zijn de meest voorkomende Chin. vormen. 
de "Groote Golf naar den kant der Chineezen», alias Golf van Siam, waarover Ptolemaeus reeds vol blijkbaar ontzag spreekt (VII, 2: 7; elders bij hem steeds: "Groote Golf»), d. w. z. in het land Kotji (zooals de Javanen) of Koetji, zooals de Maleiers het Chin. Kiao-che $=$ Tongkin weer verindischt hadden, òns Cochin-China (aldus sedert de inneming van Malaka door de Portugeezen in 1511), voorheen $\mathrm{Tjampa}$, de *Paṇdoe(ra)veste» tot tijdelijke gehoorzaamheid te dwingen; op welke Palembang zeker, Midden- of Oost-Java wellicht, vóór ca. 1000 A.D. hun zeemacht reeds hadden afgezonden.

Mevilimbañga m, "défendu par de belles murailles»= òf (en m. i. verreweg het méést waarschijnlijk) Dinding = Mal. "Bolwerk», met het oude Bruas; ò het nog oudere, in $1365 \mathrm{~A}$. D. (Nāgarakrtāgama, Z. 14:2) al genoemde, Kĕlang (= Mal. Sĕlang = "Tusschenliggende» staat?). Het eerste steunt alleen op de merkwaardige passage in Verhaal 1 der Sadjarah Mělajoe van ca. 1612, hiervóor (blz. 42) reeds besproken; maar't gaat niet aan, het gewicht van deze Maleische heugenis buiten rekening te laten. Wat echter de Tamil-term kan beduiden, mogen Tamil-kenners uitmaken. Māppappạ̄am = Groot-«Pahang», ten rechte Maleisch Paháng, dan ook Pahang (aldus in de Nāgarakrětāgama van 1365 A. D. tweemaal; $14: 2$ en $42: 2$; toen het zijn naam had gegeven aan het geheele Schiereiland, dat nà 1400 zijn naam weer ging ontleenen aan het emporium Malaka), is een bloote conjectuur. Zij staat naast de conjectuur van Venkayya uit 1899, dat er een haven van Pegoe (welke dan?), en de conjectuur van Coedès, dat er de haven aan den Westkant van den Krapas (of Pak Chan-pas; $10 \frac{1}{2}^{\circ}$ N.B.) mee bedoeld zou zijn (Coedès, p. 6, 14). Inderdaad, is de ligging van $\mathrm{Pappha} l \mathrm{a}$, dat ook in ca. 1180 weer genoemd wordt als een havenplaats in het omstreeks 1270 geschreven Vervolg van de oude Ceilonsche Kroniek Mahāvamsa (hoofdstuk LXXVI: 63; dit Vervolg begint na XXXVII : 50) - in welk Vervolg immers óók twee krijgstochten van den Sumatraanschen (lees: Minangkabauschen?) of Javaanschen (??) Vorst Tjandrabhānoe tegen Ceilon in 1251 en ca. 1255 A. D. worden gememoreerd; hfst. LXXXIII, en LXXXVIII $^{1}$ - nog

1 Zie de eerste af $z$ onderlijke behandeling van deze 2 Ceilon-expedities, van Ceilonsch standpunt beschreven als totaal mislukt in het Vervolg-deel der Mahāvaṃsa, door Prof. Kern in Bijdragen Kon. Inst. 6, II (1896), p. 240-245; thans herdrukt in zijn Verspr. Geschr. III (1915), p. 27-33: „Twee krijgs- 
geheel onzeker ${ }^{1}$. Dat de oude hoofdplaats van Pahang, Pěkan (»Markt”), nu nog de residentie van den Sultan, op 7 Eng. mijl $=11$ K.M. stroomop de koewala Pahang ligt aan een breeden, vrij ondiepen, stroom, kan men lezen in het aardige boekje van C. M. Phillips, The Malay Peninsula (2d ed., Bristol 1906; p. 99 en 96), dat ik meermalen als overzichtelijk en vertrouwbaar handboekje gebruik; maar, naast Pěkan, kan ook gedacht worden aan het iets noordelijker $\mathrm{Pah}$ ang $\mathrm{Tu}$ a op de kaart der Straits Branch (1911) gelegen aan de "S. Pahang Tua», en met aan zee de "Kuala Pahang Tua», welke òf de oude mond òf een oude delta-mond van de Pahang-rivier dus moet zijn.

Evenwel, er moet erkend, dat voor geen van deze beide plekken, noch oud-Pahang, noch jonger-Pahang $=$ Pekan, het epitheton uit 1030 A. D., "défendu par d'abondantes eaux profondes» bijster treffend is. Het tegendeel is waar. En dit geeft aanleiding om te vragen of er niet een andere, véél aannemelijker, zoo te zeggen zelfs elegante, oplossing mogelijk is? Indien we de gegevens bij Coedès over Papphāla (p. 6, 14) enten op het reeds in 1914 door FERRAND aangehangen en in zijn bespreking tochten uit den Indischen Archipel tegen Ceilon". Kern gebruilste daarbij echter de verouderde historische gegevens uit W. Knighton's History of Ceylon (1845), p. 154-159, en sprak dus van den Ceilonschen Vorst "Parākrama-bāhu III (1266-1301)"; dit moet echter wezen: Parākrama-bāhu II (1240-1275). L. C. Wijesiṇha in zijn vertaling van het $2^{\mathrm{e}}$ deel der Mahãvaṃsa (Colombo, 1889), gaf in Cap. 83: 36-48 en Cap. 88: 63 steeds "Malays" als vertaling van $\mathrm{J}$ ā vaka (l. c. p. 282, 305), maar vergat dat woord in zijn Index. Prof. Kern had den Pāli-tekst (Colombo, 1877) gebruikt. Zie over het oude eerste deel en het ca. 8 eeuwen jongere tweede deel der Mahāvamsa: Winternitz' Geschichte der ind. Litteratur, II, 1 (1913), p. 170-174, en ten deze speciaal noot 1 op p. 172. De jaartallen in den hoofdtekst zijn dus goed; verg. ook Gerini, Researches (1909), p. 624 noot (met een paar foutjes), 629, 636, en 825 (ook niet heel zuiver).

Persoonlijk ben ik vrijwel overtuigd, dat, bij het vermeerderen onzer kennis omtrent de vroegere Vorsten van Minangkabau, Vorst Tjandrabhānoe („Manestraal"; dus = Tjandra-kirana!) die in 1251 en ca. 1255 met een vloot van $D_{j} \bar{a} w a k a ' s$ (,Java-lui"), welke zich uitdrukkelijk ,'óók Boeddhisten" noemden (evenals de Ceiloneezen), landde te "Kakkhalā" - d. i. in de bocht van Kokkalai thans; op de N. O. kust 9o $2^{\prime} \mathrm{N}$. Br. - , een Koning was van Mūla Djāwa= Java prior = Minangkabau, voorganger dus ook op den troon van den Boeddhist Mauliwarmmadewa (Vorst in 1208 Çaka, zie blz. 82 noot), en den befaamden Boeddhist Adityawarman (regeert vóór 1343-- na 1375 A. D.).

1 Ferrand, in zijn daareven genoemd Compte rendu van Coedès' studie, zoekt Papphāla noordelijker nog dan Venkayya, en wel in Noord-Arakan, ca. $22^{\circ} 18^{\prime} \mathrm{N}$. Br., op grond van Ibn Sa'ìd's plaatsbepaling van Fawfal weer uit ca. 1260 A. D., juncto den Turkschen admiraal Sidi Ali Tjelebi uit 1554 A. D.; zie Journ. Asiat. 1919, II, p. 177-178. 
van Coedès' studie in 1919 nader verdedigde denkbeeld, dat dit is = Arab. Fawfal, Fawfalam, Fafalam (speciaal bij Ibn Sa'īd in ca. 1260 A. D., Relations de voyages etc., II, p. 348349, 498, 517, 647; Journ. Asiat. 1919, II, p. 177), en dien Arab. naam in zijn oudsten vorm bij Ibn Sa’îd eenvoudig vertalen in zijn Mal. aequivalent Pinang ( fawfal $=$ la noix d'arec; Ferrand in 1914,1 . c. p. 348 noot 12 ; p. 498, noot 11), dan komen we tot.... het eiland Penang, Groot-Penang, Māp pap pālam, hetwelk in den meest letterlijken zin. is "défendu par d'abondantes eaux profondes»! 1

Māyiruḍingam, "entouré par la mer profonde (comme par) un fossé» $=$ Măhasin, Mahasin $=$ Toemasik $=$ oud-Singapore, schijnt een geweldige afwijking van wat Coedès er in zocht: het Chin. Je-lo-t'ing, Ji-lo-t'ing, van Chao Ju-Kua in 1225 A. D., en dit dan weer gezocht in het "Siameesche» gedeelte van 't Maleische Schiereiland, als nabuur van Kia-lo-hi uit $1225=$ Khmersch Grahi (Mal. gĕrai is "brits, rustbank») = Faiya of Chaiya van thans (op de Oostkust, $9^{\circ} 20^{\prime}$ N.Br., aan den N.kant der Baai van Bandon); zie toch Coedès p. 10-11, en 33-35. Aangezien straks, op blz. 92, bij 't behandelen van Chao Ju-kua's gegevens uit 1225, echter blijken zal dat diens Je-1ot'ing met hooge waarschijnlijkheid niets anders is als het huidige verlaten Felutong, d.i. het landschap aan de uiterste Z.O.punt van 't vasteland van het Mal. Schiereiland (met kaap Rermoenija, alias "Rumenia» of "Romania» Point), dus onmiddellijk Oost van 't eiland Singapore, en W.N.W. van de welbekende lichttoren-rots Pedra Branca (Horsburgh Lighthouse sedert 1850), - zoo valt die schijnbare tegenstrijdigheid inéén. Groot- "Yiruḍing a m » moet dan òf Mahasin-eiland òf Jelutongschiereiland (het Malaksche Finisterre) zijn. Tamil-kenners mogen hunnerzijds weer ophelderen, wat «Yirudingarn» zou kunnen be-

1 Ook daarom zou deze oplossing zoo gelukkig mogen heeten, omdat in de Province Wellesley - dus op den vasten wal recht tegenover (d. i. Oost van) Poeloe Pinang - sinds lang, dank zij Low, Boeddhistische oudheden bekend zijn uit ca. 400-500 A.D., aansluitend bij de iets noordelijker gelegen analoge oudheden vau Kĕdah; zie volgende blz., met noot.

Evenwel: is deze oplossing juist, dan impliceert zij dat de Arab. plaatsnaam Fawfal, als vertaling van't Mal. Pinang, ouder moet zijn dan de daarnaar gevormde Koromandelsch-Ceiloneesche Papphāla. En ook Ibn Sa'īd's • beschrijving van ,l'estuaire de la Noix d'Aree” blijft moeilijkheid geven: „L'eau en est douce; il est long et large... Cet estuaire commence à un grand lac... A l'est de cet estuaire, sur la mer, se trouve la capitale F a w fa l" (l. c. p. 348).

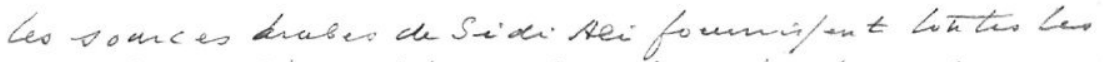


duiden, indien het niet een getamiliseerd Maleisch Djęloetoeng (de bekende gomboom, Dyera costulata Hook.f., een Apocynee) vertegenwoordigt.

Geweldig ingrijpend daarentegen is de stelling: Ilang gạçogam (i - L a ñ $\mathrm{g}$ a ç $\mathrm{g}$ a m) in 1030 A. D., "indompté (dans) de terribles batailles» = Lĕngkasuka uit 1365 in de Nāgarakrětāgama (dààrover is men 't eens) $=\ldots$ het 2 maal Wurawari in Erlangga's Calcutta-oorkonde van 963 Çaka $=1041$ A. D., en dit weer $=$ het Ganggajoe (Ganggāy u) aan den bovenloop van de soengai Djohor, in Verhaal 1 der Sadjarah Melajoe van ca. 1612 zoo historisch voorgebracht. Want tot nog toe wist niemand wààr Langkasoeka, Lĕngkasoeka lag. Alles te dien aanzien is tot heden gissing gebleven, die niet veel verder is gekomen dan toen Low, de ontdekker in 1834 en in 1848 der hoogst-antieke Boeddhistische inscripties bij $1^{\circ}$. (Cheroh) Tokun in midden-Wellesley (bijna recht Oost van Georgetown; $5^{\circ} 21^{\prime}$ N.Br.), $2^{\circ}$. te? in Noord-Wellesley (plek niet genoemd; dicht bij zee, "on a sandy side»; soms "Pasir Gebo", $5^{\circ} 32^{\prime}$ N.Br.? ?). en $3^{\circ}$. bij den Bukit Meriam in Zuid-Kědah, ook vlak bij zee $\left(5^{\circ} 35^{\prime} \mathrm{N} \text {.Br. }\right)^{1}$, - vertaler tevens in 1849 van den historischen Kědah-roman, de Hikājat Marong Mahāwangsa, in zijn vertaling van dier Verhaal I, het eiland "Lánkápurí» met Langkawi, en het dicht daarbij op den vasten wal van Kððah

1 De spellingen dezer plaatsen zijn ontleend aan de groote detail-kaart in 1911 door de Straits Branch der R. A. S. uitgegeven in 6 bladen, schaal 1:506.880, „Map of the Malay. Peninsula”, London, E. Stanford. De gegevens over deze 3 gewichtige archaeologische vondsten zijn ontleend aan de 2 opstellen van Low-zelven in Journal Asiat. Soc. of Bengal XVII (1848), Part 2, p. 62-66: An account of several Inscriptions found in Province Wellesley on the Peninsula of Malacea, met Plaat IV (oudheden van Tokun), en Naschrift van Laidlay (p. 66-72); en in J. A. S. B. XVIII (1849), Part 1, p. 247-249: On an inscription from Keddah, met Plaat X (inscriptie van Bukit Meriam), met slotnoot weer van Laidlay. De allerbelangrijkste Boeddhistische oudheid, een wereldbol met pajoeng van 7 hemels, en 4 bijschriften, werd reeds in 1834 door Low gevonden op die ongenoemde plek in Noord-Wellesley, en in Jan. '35 - doch zònder eenig bijschrift - als Plaat III afgebeeld in J. A. S. B. IV (1835), tegenover p. 56; slechts dd. 14 Jan. aldus daar genotnleerd: „Read a letter from Major Sutherland [toenmaals te Bombay] forwarding the Ancient Inscription pres. ented by Captain J. Low, on the 3rd December".

Een en ander is toen nader behandeld door Prof. Kern in 1884 (Ve:sl. en Meded. Kon. Ak., afd. Lett. 3, I; nu herdrukt in Verspr. Geschr., 1915, p. 257-261); wat hierboven in den hoofdtekst van $\mathrm{Z}$. naar N. werd genoemd als $\mathrm{n}^{\text {os }} 1,2$, en 3, behandelde Kern van $N$. naar $Z$. De gegevens van Low, Laidlay, e. a. werden daarna door Dr. Rost herdrukt in de Miscell. Papers relating to Indo-China, (First Series), I, 1886, p. 221-234, met 3 platen. 
gestichte rijkscentrum "Lánkásuká» met Gunong Ferai (Siameesch: K'hau Srai) vereenzelvigde; dus resp. met het eiland op ca. $6^{\circ} 25^{\prime}$, en den berg op $5^{\circ} 48^{\prime}$ N.Br. ter Westkust.

Daarnevens gisten PELliot en HuBER in 1904: Njangkasi (Ñankasī), d.i. de Pegoeaansche naam van Tenasserim; ik zelf in 1904: Selangor(?); Gerini opnieuw in 1905: een oud-Kedah bij den Goenoeng Djerrai (Jerai) of Kedah Peak ( $5^{\circ} 48^{\prime}$ N.Br.), waarbij Blagden in 1906 zich heeft aangesloten ${ }^{1}$; ook Hirth en Rockhill hebben zich in 1912 bij deze laatste interpretatie neergelegd in hun uitgaaf van CHAU JU-KUA, die in $1225 \mathrm{Ling}$ ya-ssï-kia noemt als derde der 15 staten, onderhoorig aan Palembang (o.c. p. 62), en het als Ling-ya-ss ï afzonderlijk ook beschrijft (p. 68-69), waar zij in de noot concludeerden: "It is the Lengkasuka of the Mājapāhit empire, the original capital of Kedah, near Kedah Peak (Gūnong Jerai), on the W.coast of the Malay Peninsula». Ook Coedès (1918, p. 13) komt tot de conclusie: "de retenir l'identification d'Ilaingă [in de Tanjore-inscriptie van 1030 A. D.] avec Lankasuka, sa localisation dans le Sud de l'Etat de Kedah, et sa dépendance vis-à-vis du royaume de Palembang». Kortom, volgens de communis opinio van velen, zou het 't nog in 1365 volop levende oudKédah zijn geweest, waarover Colonel Low — denzelfden der Singapore-inscriptie! - in 1848 de eerste ongedateerde maar zeer oude, en onmiskenbaar-Boeddhistische inscripties had publiek gemaakt, die in 1884 voor het eerst door Prof. KERN werden verklaard en gedetermineerd als "ten ruwe (uit) 400 na Chr.». WILKInson daarentegen hield zich — zonder Low's naam te noemen; zóó zijn zijne manieren! - in 1908 aan een gedeelte van Low's eigen oudere opvatting ${ }^{2}$, toen deze, in zijn vertaling der Marong

1 Zie resp. Low in Journ. Ind. A Arch. III (1849), p. 8-9; Pelliot in zijn Doux itinéraires etc., Bulletin Ecole fr. d'Extr.-Or. IV (1904), p. 345, en vooral 407; Huber, ibid. p. 475; Rouffaer in Encycl. v. N. I. (1॰ druk, in afleveringen verschenen), IV (1905), p. 384a; Gerini in Journ. R. As. Soc. 1905, p. 495; Blagden, ibid. 1906, p. 118. Verg. Krom in de Nāgarakṛtāgama, ed. Kern-Krom (1919), p. 260, en VIII (Addendum).

2 De woorden van den hoogst verdienstelijken WiLkinson - die echter de ellendige "methode" heeft aangenomen in zijn eigen werk niet te vermelden wat hij aan anderen ontleent, of te danken heeft - , luiden (Hoofdstuk ,Early Civilisation"):

"The general conclusion to be drawn from the traces of ancient culture in the Peninsula is that the southern portions of the country were often visited but never really occupied by any civilised race until the Malays came in 
Mahāwangsa, de volgende noot gaf bij het in Verhaal I daarvan optredende "Island of Lánkápurí»: "Lánkápurí is the ancient name of the cluster of Islands now called by the natives Lánkáwárí, and laid down in our maps as the "Lancavy Islands»... These are bold Islands, formed of and flanked by towering masses 'of limestone... But Langkapura was the name of Ceylon and also of its capital.... There was a Lankapuri likewise lying somewhere betwixt Palembang and Jambi in Sumatra., (Journal Ind. Archip. III, 1849, p. 8, noot $h$; of herdruk, Bangkok 1908 , p. $11-12$, noot $h$ ). Deze laatste opmerking van den verdienstelijken Malaicus Low vindt haar bevestiging in het zoo overrijke, en nog volstrekt niet verouderde Aardrijkskundig en Statistisch Woordenboek van N. I., II (1869) i. v.: "Langka Poera, een eiland dat tusschen de rivieren Palembang en Djambi op Sumatra gelegen is, en volgens de overlevering de eerste plek die na den zondvloed droog werd.» (p. 322b). ${ }^{1}$ FERRAND ten slotte, wees in het "Appendice III" tot zijne studie van 1918 (II, p. $134-145 ; 153-154)$ voor de plaats van Lěngkasoeka met nadruk op de Oostkust van 't Schiereiland, tusschen de landengten van $\mathrm{Kra}\left(10^{\circ} 30^{\prime}\right)$ en van Ligor $\left(7^{\circ} 30^{\prime}\right)$, speciaal op dit laatste; en concludeerde: "Lang-ya-sieou se trouve ainsi en plein isthme de Ligor» (p. 142).

A.D. 1400. Such a conclusion would not, however, be true of the Northern States, of Kedah, Kelantan, Trang [of Tarang; W. van Pataloong; thans het Zuiden vormend van den Staat Puket op de Westkust; ca. $7^{\circ} 30^{\prime} \mathrm{N}$. Br.] and Singgora. There we find undoubted evidence of the existence of powerful Buddhist States like that of Langkasuka, the kingdom of alang-kah suka [iets als ons "Elck-wat-wils"] or of the Golden Age of Kedah, still remembered as a fairyland of Malay romance. This Langkasuka was a very ancient State indeed. It is mentioned in Chinese records as Langgasu as far back as A.D. 500 , and was then reputed to be four centuries old; it appears (in Javanese literature) as one of the kingdoms overcome by Majapahit in A. D. 1377 [lees: vóór 1365; Wilkinson werkt hier met het foutieve gegeven van Gerini in Journ. R. As. Soc. 1905, p. 494]; its name probably survives to this day in the "Langkawi" islands off the Kedah coast." (Papers on Malay subjects. History. By R, J. Wilkinson. Kuala Lumpur, 1908, p. 8). Oók afgedrukt in Twentieth Century Impressions of British Malaya, London 1908, p. 78.

1 Low heeft ziju gegeven over een „Lankapuri” tusschen Djambi en Palembang zeker ontleend aan MARSDEN, te zamen met een studie van J. WILFORD in dl. $\mathrm{X}$ der Asiatic Researches (1 ${ }^{\circ}$ ed. 1803, $2^{\circ}$ ed. 1811); misschien deels ook aan Newbold. In alle 3 drukken van Marsden's History of Sumatra $\left(1^{\circ}\right.$ ed. 1783 , p. $273 ; 2^{e}$ ed. 1784 , p. $271 ; 3^{\circ}$ ed. 1811, p 310 ) wordt een vertaling gegeven van een passage uit een brief van Sultan Gagar Alam van Minangkabau uit ca. 1730 aan Sultan Gandam Sjah van Moko-Moko (op den 
Er zal nu echter bewezen worden, dat - met $90 \%$ waarschijnlijkheid - dit alles er nààst was; maar dat, integendeel, Lèngkasoeka van 1365 A. D., Ling-ya-ssï-kia van 1225, I-Lañgāçogam van 1030 A. D., terug te vinden zijn in het geweldig-sterke rijk Wurawari $=$ Ganggāyu, met hoofdstad Lwarām, hetwelk in 928 Çaka $=1006$ A. D., blijkens Vorst Erlangga's tweetalige inscriptie (Sanskrit en Oudjav.) van den berg Penanggoengan, thans te Calcutta, een groote débâcle bracht over het eiland Java; en dat eveneens het nog weer drie eeuwen oudere $\mathrm{L}$ ang-ka-su van I-tsing uit ca. 692, en het alwéér ca. twee eeuwen oudere land van Boeddhistische neigingen Lang-ga-su of Lang-ga in de Annalen der Liang-dynastie (502-556) - door Groeneveldt in zijne Notes van 1876 aarzelend met West-Java vereenzelvigd, p. 12 - ook dààr, in dien eigensten Hoek van Djohor, teruggevonden moet worden; ja . . dat, blijkens de kostelijke zinsnede in die Liang-Annalen: "The people say

troon gekomen in 1728; zie $33^{\mathrm{e}}$ ed. p. 354), luidende: dat de vogel, dien God uitzond na den zondvloed, ,the first place he alighted upon was the fertile island of Lankapura, situated between Palembang and Jambi, and from thence sprang the famous kingdom of Manancabow" (aldus in 3e ed.). En bij Newbold (Account of the British settlements in the Straits of Malacca", 1839, II), die een investituur-geschrift (téroemba) vertaalt van den Jang-di-pĕrtoean Sati van Minangkabau uit 1826 (zie er p. 81 en 89) aan den nieuwen Jang-di-perrtoean der Nĕgri Sĕmbilan op Malaka, komt deze gevarieerde passage voor: "The Almighty caused the dry land, called Pulo Langkavi [lees: Langkapuri], to descend between Palembang and Jambie, as the place of residence for the original sovereigns of the world" (p. 83, noot). Maar de door Low gebruikte vorm "Lankapuri" komt voor in de studie van Wilford bovenbedoeld: „Essay on the Sacred Isles in the West, with other Essays", waarin hij, handelend over de 2 Trikūța's in de Purāna's - n.l. één „Trits" van eilanden in het Z. O., en één in het N. W. der wereld; waarvan elke trits weer bestaat uit 1 Goud-, 1 Zilver-, en 1 IJzer-eiland -, zeide: "These three islands in the south.east, are in general called Lanca; and in every one of them is supposed to be a city called a Lancípuri, and there is actually a place of that name in Sumatra, according to Mr. Marsden" (2e ed., p. 142); men ziet hier tevens, hoe Wilford het ,eiland Langkapoera" der Minangkabausche overlevering eenigszins vervormt tot een der 3 steden Langkapoeri der Hindoesche overlevering, zooals hij deze geeft. Wilford gaat dan zelfs verder, en schrijft o. a.: "the straits of Málácí are called, in the Puránas, [en wel voegt hij toe in een noot, in het "Scanda-purána, section of Tapi Chanda"] Lancá-dwára, or the gates of Lancá" (p. 143); en: „The Gold-Island, or Suvarna, is also called Maha-Lancá or Má-Lancâ", waarin hij dan zelfs den naam Malaka wil terugvinden (p. 142).

Het gegeven in het Aardr. en Statistisch Wdb. van 1869 berust gewis op wat Dr. Sal. Müller schreef in zijn "Bijdragen tot de kennis van Sumatra" 
that their country was established more than 400 years ago" (Groen. p. 10; of $2^{\text {e }}$ druk, 1887, p. 136), het Langka-proper van het heldendicht Rāmāyana ook dààr gezocht moet worden. Dat «Lankā dus, dat steeds met Ceilon wordt vereenzelvigd, doch waarvan JACOBI in zijne concordantie *Das Râmâyaṇa» (1893), op p. 90-93 reeds had betoogd dat Langka niet Ceilon oorspronkelijk was geweest, en waarmee WINTERNITZ in zijne Geschichte der indischen Litteratur I, $2^{\text {e }}$ Ausg. 1909, p. 414 noot 3 instemde, aldus: "( Lank kā) Nicht, wie man gewöhnlich anzunehmen pflegt, Ceylon. Erst eine viel spätere Zeit hat Lañkā mit Ceylon gleichgesetzt. Siehe JACOBI, Râmâyaṇa, S. 90 ff.»

Welke gewichtige gevolgtrekkingen dan weer te trekken zijn uit deze nieuwe localiseering van Langka-proper (oftewel Langkasoeka) met oer-Djohor, voor een deel der bouwmonumenten van Java, zal tevens in 't vervolg dezer afdeeling sub B blijken (zie blz. 103-105).

Allereerst kan er waarschijnlijk nieuw licht worden gebracht in den plaatsnaam Luarām, Lwarām, hoofdstad van het rijk Woerawari, door Prof. Kern in 1913 alleen getranscribeerd, en ook hiervóór (blz. 43, noot 1) nog als onopgehelderd ter zijde gelaten. Dank zij eenige aanwijzingen toch van Dr. Кком, zou

(1846), p. 91; hetwelk weer een samenvatting is van Marsden + Wilford.

Als versterkingen der Minangkabausch-Maleische overlevering omtrent dit éérste Vasteland na den Zondvloed, geheeten Langkapoera, var. Lang. kapoeri, - Newbold's "Langkavi" is een leesfout voor "Langkapuri"; zie toch Ferrand, II, p. 56 noot 6 -, kan nog gewezen: $a$. op de anonieme (doch door RAFrLes vervaardigde) korte vertaling van een Sadjarah RadjaRadja Poelau Pĕrtja, weleer in bezit van den Sultan van Indrapoera, als $\mathrm{n}^{\circ}$ XII van dl. II der Malayan Miscellanies (Bencoolen, Sumatran Mission Press, 1822); waarin: „Sikatimuno [een water-reus; Sakti Moena] was then destroyed by Chemundang Giri [ = het zwaard van den Koning, nazaat van Iskandar], and the island of Lunkapura became land by the will of God. It became large and extended to the foot of the mountain. Thereafter the king landed on that island, called also Saguntang-guntang Penjaringan [ = Palembang, zegt later p. 7] and situated between Palembang and Jambi, and dwelt there, etc." (p. 3-4); b. op het relaas der Minangkabausche oorsprongs-legende, zooals FRANCIs dat gaf in 1837 , afgedrukt in T. v. N.-I., $2^{\text {en }}$ jrg. (1839), I, p. 100-103, en waarin gesproken wordt van "het eiland Langkapoerie in de Ceilonsche Zee" (p. 102), zooals nader blijken zal uit de uitvoerige aanhaling aan het slot van ons $I I^{\circ}$ Gedeelte; $c$. op de Minangkabausche legende, verteld door Westenenk in Tijdschr. Bat. Gen. dl. 55 (1913), p. 235, waar gesproken wordt van „het hoofd van den reus Katimono verslagen in een land tusschen Palèmbang en Djambi gelegen", waarmede weer datzelfde "Langkapoera" bedoeld is. 
ik durven vragen: mag Lua rām niet gesplitst in lua $+\bar{a} \bar{m} m$, waarin lua staat voor luah? Het eenige bezwaar daartegen is, dat, bij het wegvallen der $h$, de $a$ dan lang had dienen te worden; doch er behoeft maar gewezen te worden op Oudjav. varianten als wawahu naast wah wahu, warigaluh naast warihgalu h (V. d. Tuuk, III, p. 444a; 493b), om dit bezwaar niet overwegend te achten. Lwah nu is het gewone Oudjav. woord voor « rivier, stroomend (zoet) water»; Van der Tuuk (III, p. 711b) geeft als synoniem Skr.-OJ. ganggā op! Het tweede lid der samenstelling zou dan zijn Skr. rām=rāma, «liefelijk» (pers. meded. Dr. KROM). Het bezwaar dat hier een Maleisch-Polyn. woord (luah, lwah) aan een Sanskrit-woord gekoppeld zou zijn, valt weg tegenover b.v. hybridische varianten Djala-langga en Nīralangga voor den zuiver Mal.-Polyn. naam (doch met averechtsche constructie) van Vorst Er-langga, den "Water-slurper». ${ }^{1}$

Indien dus de korte eerste $a$ in $\mathrm{Lu}$ a $\overline{\mathrm{a}} \mathrm{m}, \mathrm{L} w$ a $\overline{\mathrm{a}} \mathrm{m}$, geen overwegend bezwaar is, dan zou deze plaatsnaam uit 1006 A. D. geheel gelijkwaardig zijn met....Ganggāyu uit ca. 1612, in welken laatsten plaatsnaam een dergelijke hybridische koppeling in andere volgorde plaats vond; en dit is dan ook weer met kleine nuance (Klaar-water voor Mooi- of Lief-water) $=\mathrm{Wura-}$ wari uit datzelfde 928 Çaka! Dank zij die kostbare aanduiding in Verhaal I der Sadjarah Melajoe:.... «negri Ganggayu. Shahadan dehulu kala-nya negri itu negri besar, kota-nya deri-pada batu hitam, datang sekarang lagi ada kota-nya itu di hulu sungai Johor (Shellabear, ed. 1898, p. 8), zouden we hier, te Langkasoeka,

1 In 1885 schreef Prof. KeRs, bij zijn behandeling der Sanskrit-inscriptie op den Calcutta-steen: „Den naam Er-langga, die echt Maleisch-Polynesisch is, kon hij [n.l. de dichter van 't opschrift] niet verzwijgen, maar hij veroorlooft zich toch het woord hier en daar te sanskritiseeren, door 't eerste lid der samenstelling, er, water, te vertalen, zoodat de doorluchtige heerscher door hem ook wel Jala-langga en Nīra-langga genoemd wordt." (Bijdr. Kon. Inst. 4, X, p. 7; of herdruk in Verspr. Geschr. VII, 1917, p. 90). In een noot voegde Kern daaraan o. a. nog toe: „Aangaande de eigenaardige vorming van den eigennaam weet $\mathrm{ik}$ geen verklaring te geven. In Balineesche HSS. is langga verhaspeld tot langghya." Verg. ook V. d. Tuuk's Wdb. I, p. 117b, en III, p. 831, 841b, i.v. Airlangga-A irlanggja, en langga-langgja.

Dr. KROM vermoedt, dat in de vervorming van dit tweede lid, het in 't Oudjav. overgenomen Sanskrit-ww. la ng h an a, „overschrijden”, óók tot Oudjav. l anggy a na vervormd (zie V. d. Tuuk, III, p. 839a, 841b), een rol heeft gespeeld; to meer, daar langgana nà Erlangga's tijd voorkomt in Vorstentitels van Oost-Java. In den Vorstennaam Er-langga ligt dus, volgens Dr. Krom, wellicht een toespeling op Er-langgana = "Water-overschrijder". 
dan óók teruggevonden hebben het geweldige Woerawari uit Erlangga's tijd, met hoofdstad Lwarām.

Nu wàs Langkasoeka ook geweldig. In de Tanjore-inscriptie van 1030 A. D., heet I-Lañgāçogam: «indompté (dans) de terribles batailles». Dat klopt! Want na den triomftocht van 1006 naar Oost-Java, viel in $\mathbf{1 0 3 2}$ Woerawari opnieuw Erlangga in diens eigen land aan (zie blz. 43; en 73, met noot 1).

In 1225 A. D. zijn de bordjes verhangen: Langkasoeka is afhankelijk geworden van $\mathrm{San}-\mathrm{fo-ts}$ ' $\mathrm{i}=$ Palembang; want CHAU JU-KUA memoreert in dat jaar ${ }^{1}$ de 15 Onderhoorigheden van Palembang aldus - waarbij hier de van Hirth \& Rockhill in hun uitgaaf van 1912, c.q. van Coedès overgenomen identificaties cursief zullen worden worden gedrukt; doch mijn eigene, van hen afwijkende, gelijkstellingen KLEIN-KAPITAAL:

1. P'öng-föng (Pahang); 2. Töng-ya-nöng (Trĕngga$n a u)$; 3. Ling-ya-ssï-kia (= Lĕngkasoeka=WOERAWARI); 4. Ki-lan-tan (Kĕlantan); 5. Fo-lo-an (Mal. PoElowan $=$ *Eiland-groep $=\mathrm{m}$.i. de groep eilanden aan den mond der Kělang-rivier in Zuid-Sellangor; Hirth \& Rockhill volgen Gerini, en gissen "Beranang» aan den Z.-oever der Langatrivier, in Zuid-Sellangor, maar waar niemand iets verder van weet); 6. Ji-1o-t'ing (JeLUTONG, hiervóór op blz. 85 reeds genoemd $^{2}$; dus ò de uiterste Z.O.hoek van 't vasteland van Djohor, òf $M \bar{a}-Y$ iruḍing a $m$, en dan 't méést waarschijnlijk = MĀ-HASIN = TOEMASIK); 7. Ts'iën-mai (=??; soms = Semang ?, en dan $=$ het "Saimwang , in Zang 14:2 der Nāgarakrětagama; andere gissingen zijn Djambi(!) van Schlegel in T'oung Pao, 2, II, 1901, p. 135; of (Teloek) Semawe van Gerini, Researches, 1909, p. 627); 8. Pa-t'a

1 Dat 1225 het juiste jaar is van CHAU JU-KUA's werk $\mathrm{Chu}-\mathrm{fan}-\mathrm{ch} \ddot{\mathrm{i}}$ (of ${ }^{\circ} \mathrm{ch}$ ih) heeft Pelliot bewezen in zijn hoogst belangrijke bespreking der uitgave Hirth \& Rockhill (op het titelblad: St. Petersburg 1911; op den omslag: St. Petersburg 1912) in T'oung Pao XIII (1912), p. 449. Hirth \& Rockhill zelf waren in hun editie niet verder gekomen, dan dat Chau Ju-kua zijn werk zou geschreven hebben tusschen 1242 en 1258 A. D. (p. 136-137, noot 2). Pelliot schrijft: Tchao Jou-koua, en Tchou fan tche.

2 Aan Gerini (Researches, 1909, p. 826) komt de eer toe, in verband met Jih-lo-t'ing, de aandacht te bebben gevestigd o.a. op dit „Jelutong district on the south-eastern end of the Malay Peninsula (above Ramenia Point)". Plaatsnamen (dus géén landschaps-namen) Jelutong kan men verscheidene vinden op een gedetailleerde kaart van 't Mal. Schiereiland; een tweede dis. trict van dien naam ligt nog op Poeloe Pinang, even beZ. Georgetown. 
(wel Batak, zooals Schlegel, l.c., vermoedde; maar dan niet "the Battak's or Batta's in the North of Sumatra", doch veeleer Batak's in het binnenland toenmaals van de Chersonesus); 9. Tan-ma-ling (Tāmbralingga $=$ Ligor, oftewel Lakhon, Nakhon; zie hiervóór blz. 79); 10. Kialo-hi (Grahi = Chaiya, Faiya; Coedès, 1918, zie hiervóór blz. 85); 11. Pa-lin-föng (Palembang); 12. Sin-t'o Sunda); 13. Kiën-pi (Kampe, alias KampeI, bij de Aroebaai, het «Kāmpe» ook uit 1365 der Nāg. kṛ., Zang 13:1; en niet "Koempai» (alias: Kompeh), aan de uitmonding der Batang Hari; en nog véél minder «Kampar» ${ }^{1}$, waarvan Hirth \& Rockhill beweren, dat deze laatste eidentification... does not admit of doubt», p. 72 !); 14. Lan-wu-li (Lambri $=$ Groot-Atjeh); 15. Si-1an (Ceilon). (o. c. p. 62-66).

Al moet men nu deze lijst van Palembang's onderhoorigheden in 1225 ook weer niet als evangelie beschouwen - het $\mathrm{Pa}$-linföng als onderhoorigheid van San-fo-ts'i maakt een zotten indruk; het ontbreken van $D j a m b i$ verbaast; en de onderworpenheid van $\mathrm{Si}$-lan zal wel alleen in de verbeelding van òf Chineezen of Palembangers hebben geleefd ${ }^{2}-$, zoo is hier het voor ons thans gewichtigste, dat Lengkas oeka onmiddellijk volgt nà de staten Pahang en Trĕngganau op de Oostkust, en vóór Kĕlantan. Ook dit pleit alweer: Lěngkasoeka lag ook dààr, aan dien Z.O.hoek der Chersonesus; maar volstrekt niet bij Kědah.

Eenzelfde resultaat geeft de nadere beschouwing der beschrijving van Ling-ya-ssï en Fo-lo-an bij Chau Ju-kua (l. c. p. 68,69). Ling-ya-ssï (aldus hier, p. 68, geschreven; dus zonder «kia» aan het eind) was 6 etmaal zeilens van Tan-ma-ling, maar er was ók een overland-weg; Fo-lo-an was 4 dagen (overzee) van Ling-ya-ssï-kia (sic, p. 69; dus nu weer voluit), maar er was eveneens ook een overland-weg; van beide staten wordt uitdrukkelijk er bij vermeld, dat elk "sends yearly tribute to Sanfo-ts'i»; terwijl van Fo-lo-an nog nader wordt verzekerd: "Its neighbours P’öng-föng, Töng-ya-nung and Ki-lan-tan are

' Dit blijkt overtuigend uit de nadere beschrijving van het ,kingdom of Kién-pi" bij Chau Ju-kua (o c. p. 71). Het wordt daar toch gezegd $\frac{1}{2}$ maand zeilens van $\mathrm{S} a \mathrm{n}-\mathrm{fo-ts}$ 'i en 5 dagen zeilens van $\mathrm{Lan-w}$-li te liggen. Oók het $\mathrm{K} \overline{\mathrm{a}} \mathrm{mpe}$, dat in Zang 13: 1 der Nāg. kṛtāg. wordt genoemd nà Pane, en vóór $\mathrm{Harw}$ (Aroe), is niets anders dan ditzelfde (Poeloe) Kampei van thans.

2 Of moet gedacht aan Tjandrabhānoe later in 1251 en 1255 A. D. (zie blz. 83)? 
like it» (p. 69). Nemen we dan, aan de hand der gegevens bij C'OEDÈs (1918, p. 17), als vaststaande aan, dat Chin. Tan-maling $=$ Skr. Támbralinga, niets anders is als Ligor (Lakhon) ${ }^{1}$, dan komt alles schitterend uit: Lèngkasoeka $=$ Wurawari $=$ oud-Djohor; en Fo-lo-an = Mal. Poelowan, Jav. Poelon $=$ "een eilandengroep» (Roorda-Vreede, 1901, II, p. 285b) = oud-Kĕlang. Het fantastische "Beranang» van Gerini, hoewel het op dezelfde plek zoowat uitkomt - de kuala Langat vormt het zuidelijkst deel der delta van de sungai Kĕlang, met de nu zoo welbekende haven Port Swettenham - geven we dan verder cadeau.

Zagen we hierboven, dat hij CHAU JU-KUA in 1225 de naam Hasin of Mahasin niet meer voorkomt, en de naam Toemasik nog niet, doch dat alleen in zijn Ji-lo-t'ing - zoo het niet enkel Oedjoeng Tanah (Land's End, Finis Terrae), Felutong of Djęloetoeng van thans, beteekent - ook oud-Singapore verscholen kan zijn, geheel anders staat de zaak ca. een anderhalve eeuw later, in 1287 Çaka $=1365$ A. D. bij den Oudjav. dichter Prapantja, met Zang 14:2 zijner Nāgarakrětāgama.

Van deze strofe 2 geef ik hier de letterlijke vertaling, welke ik dank aan Dr. KROM: "De onderhoorigheden (n.l. van Madjapahit) op Pahang [= hier: de hééle Chersonesus; Malaya], met als voornaamste Hoedjoeng Medini [Skr.-Ojav. medini $=$ lëmah = tanah; zie V. d. Tuuk, IV, 1912, p. 558b] (zijn deze): in Lěngkasoeka en in Saimwang [Sĕmang], in Kalantěn, in Tringgano; Naçor [soms = de stad Pahang?; of = Patani??; niet echter Nakhon], Paka [op de Oostkust, ca. $4^{\circ} 30^{\prime}$, beZ. Dungun; zie ons $I I^{e}$ Gedeelte, sub V-VI], Moew ar [zie reeds blz. 27], Doengoen [nu Tanjung Dungun en Kuala Dungun, in Zuid-Trěngganau, $4^{\circ} 45^{\prime}$ N.Br.]; in Toemasik, in Sanghyang Hoedjoeng [m.i.: Tanjung Buru $=T$. Bulus van thans, of anders Tanjung Tuan = Cape Rachado nu; òf Hujong Salang (alias Funk Ceylon) van thans; dus òf de uiterste Zuidpunt, òf de karakteristieke "gespleten $»$ midden-punt; of (?) de hooge N.W. eiland-punt der Westkust van de Chersonesus], in Kělang, Kẹ̣a(h), Djere [òf Fering, alias Jambu, vlak O. van de stad Patani (welke laatste niet wordt genoemd; tenzij verscholen b.v. in "Naçor»); òf wellicht (Gunong) Ferai, alias "Kedah Peak», dus oud-Kĕdah, zooals ik

1 Coedès verwijst er in zijn noot 5 nog naar een Chin. gegeven uit 1196 A.D. bij Schlegel (in T'oung Pao, 2, II, 1901, p. 126) waarbij Tan-ma-ling gezegd wordt 10 etmaal zeilens van Kambodja te liggen. Dit klopt zeer goed. 
thans ook durf vragen], in Kandjap [=Singkěp??], in Nirān [= Karimoen ??], met de bijbehoorende eilanden.» ${ }^{1}$

Neemt men bij deze lijst nu aan, dat dit Lěngkasuka van 1365 A. D. gelegen was bij den Goenoeng Djërai in Zuid-Kĕdah $\left(5^{\circ} 48^{\prime} \mathrm{N} . \mathrm{Br}\right.$.), dan maakt de opsomming een verbazenden sprong; neemt men daarentegen aan, dat Lěngkasuka dààr ongeveer lag, waar (met belangrijke tusschenpoozen) van 1530-1855 de hoofdzetel stond van het rijk Djohor (oud-Port. For; 17 -eeuwsch Jav. óok Djor, ons bewaard in de beruchte Moh. perdikan-desa Kadjoran bij Wẹ̦i, afd. Klațen, dus ka-Djohor-an of *Djohoreezen-desa,, de desa van Raden Kadjo(ho)ran, schoonvader van Troenå Djåjå; Eng. Fohore), n.l. Djohor Lama (aan de Oostzijde van den fjord-achtigen benedenloop der soengai Djohor), dan komt alles schitterend op zijn natuurlijke plaats. Prapantja noemt dan toch op het schiereiland "Pahang»: vóórop, "als voornaamste», Hoedjoeng Tanah (ca. $1^{\circ} 25^{\prime} \mathrm{N} . \mathrm{Br}$.) $=$ Felutong van thans $=$ Ji-lo-t'ing in 1225; dan $2^{\circ}$. Lěngkasoeka (ca. $1^{\circ} 36^{\prime}$ N.B.) $=$ ongeveer Djohor Lama van thans = Langka-proper van 100500 A. D. = Lang-ka-su van ca. 692 A. D. (I-tsing ; zie toch hierachter blz. 101-103) $=$ Wurawari in 928 en 954 Çaka $=$ (weer) Langgāçogam in de Tamil-inscriptie van $1030 \mathrm{~A}$. D.; en $3^{\circ}$. het Šmang-binnenland. Daarna volgen 4 Staten op de Oostkust (Kelantan; Trěngganau; Pahang-proper (?) ${ }^{2}$; met vermoedelîjk Paka daartusschen), 1 Staat op de Z.W.kust (Muwar), en nog 1 Staat op de Oostkust (Dungun). Daarna komt pas Toemasik als $n^{\circ} 10$ in de rij $=$ Mo-ho-sin, (Mā-)Hasin; dàn een vooreerst niet beslist te localiseeren "Sanghyang Hujung", dus de een of andere sterksprekende en daardoor "heilige" kaap op de Westkust; daarna dan komen 2 of 3 Staten aan die Westkust (Kelang, Kædah, en (?) Djerai); om te sluiten met 2 vooralsnog raadselachtige namen van — waarschijnlijk - eilanden nabij en bezuiden Singapore, waarin we echter juist den naam van

1 Gelijk men weet, heeft Prof. Kern Zang 13-14 van Prapantja's Lofdicht wel reeds in 1903 in den Ind. Gids uitvoerig besproken, maar nimmer letterlijk vertaald; zie thans de uitgave Kern-Krom (1919), p. 51 en 13, alsmede Krom's Aanteekeningen op p. 260. Eenige verbeteringen in den uitleg zijn hierboven opgenomen, vooral door splitsing van Pakamuwar; verg. ook hiervóór blz. 21 over 5 à 6 nog onvoldoend te herkennen landstreken van deze 17 namen.

Over Muwar zie vooral hierna blz. 113-114, met de noot op blz. 114-115.

"Op het eiland „Malayu" wordt immers ook „Jāmbi" genoemd als éérste, en op 't eiland „Tañjungnagara" aan het slot de hoofdstad,"Tañjungpurī" $(13: 1 ; 14: 1)$. 
«Bintan» of van «Karimun» pijnlijk missen. Er komt aldus orde en systeem in Prapantja's lijst, evenzeer als bij zijn lijst van staten op Malayu = Sumatra in Zang 13:1-2.

Konden we nu maar weer beschikken oven een ander geheim; het geheim van den Minto-steen in Zuid-Schotland! Want op deze kolossale inscriptie van een Oostjavaanschen Vorst Çrī Widjajaloka uit 846 Çaka $=924$ A. D., tot begin 1813 gestaan hebbende te Ngendat (tusschen Malang en Batoe), daarna door Raffles als present- «Javan rock» overgezonden aan den aftredenden G. G. Lord Minto (1807-13) te Calcutta ${ }^{1}$, en door dezen toen meegenomen naar zijn patriarchaal Minto House bij Hawick (Z.O. Schotland), komt - op de gedeeltelijke transcriptie door Cohen Stuart in Mei 1875 naar een foto gemaakt (zie Oudjav. Oorkonden, ed. Brandes-Krom, 1913, p. 42) - in regel 42 van den achterkant ó́k dat Hasin (p. 48) weer voor. En ook in regel 4-5 een "parujar i siran hujung galuh" (pag. 45), dus: een "woordvoerder voor den $\operatorname{Sir}[i k]{ }^{2}$ (van) Oedjoeng Galoeh"; welk Oedjoeng Galoeh = Oedjoeng Poetri = Djoeng Galoeh (zie V. d. Tuuk's Wdb., IV, p. 183b, 448a, en I, p. 294b), ò het Hujung Galuh der inscriptie van Airlangga uit 959 Çaka (Oudjav. Oork. p. 135), en dan wel thans het Mĕgaloeh aan de Brantas-rivier (beN.W. van Djombang) kan zijn - vermoedelijk tevens de plek waar Vorst Djaja Katong van Kẹ̣iri in 1293 door zijn overwinnaars, de Tartaren en Chineezen, gevangen werd gezet, en de Woekir Polaman dichtte (zie Pararaton, ed.Brandes 1896, p. 76 en 104) ${ }^{3}$-; òf ... het Warigaluh, waar VAN DER TUUK in zijn Kawi-Wdb. III (1901), p. 493-494 zoo hóogst opmerkelijk over spreekt. Immers, thans nog bestaat

1 Verg. Raffles History of Java (1817), II, Appendix I, p. CCXXI, noot: uittreksel uit een brief van Lord Minto, dd. [Calcutta], 23 Juni 1813, in antwoord op Raffles' schrijven, dd. 5 Mei, welke aan Minto had gemeld, dat „the great stone... was put on board the Matilda”, begeleid door „Colonel Mackenzie's account of this curiosity". Of deze nota méer heeft berat dan de mystificatie-vertaling in Raffles' gezegd Appendix? Over de juiste (zéér waarschijnlijke) vindplaats, zie Dr. Krom in Bijdr. Kon. Inst., dl. 73 (1917), p.30-31.

Naar mijn vermoeden is toen tegelijk de zgn. „Calcutta-steen" medegegaan, door Holle in ca. 1883 opgespoord, maar reeds in 1848 door Laidlay als te Calcutta in 't Museum aanwezig vermeld (zie toch hiervóór blz. 58, met noot 1).

- De aanvulling van siran tot sirika $n$ is conform het advies van Dr. Krom. Zie in ons $I I^{\circ}$ Gedeelte, aanvang, de diverse aanhalingen met „Hasin" en „Ujung Galuh", alsmede „Langka”, uit de Oudjav. Oorkonden.

3 Of thans, in de $2^{\circ}$ ed. Brandes-Krom (1920), p. 92 en 123. 
warigaloeh in het Jav, in den zin van "visscher, vanger van visch,; maar in het Middeljav. en Bantensch-Jav. had het den zin van «koopman», en óok van "baas of aanvoerder van zeevaarders», aequivalent aan het Mal. pawang, ouder-Mal, poewawang, oud-Jav. (al in de inscriptie-Gandasoeli, 769 Ç.; O. J. O., 1913, p. 4) pu-hawang, d. i. "schip-heer», schipper. We zijn hier in de sfeer der oude internationale zeevaart van de Javanen, toen zij, te zamen met de Maleiers, de voornaamste vrachtvaarders waren onder de Indonesiërs in den Indischen Archipel, met name in de Oostelijke helft.

Met de tegenwoordig beschikbare gegevens is het niet mogelijk hierin door te dringen. Toch stel ik er prijs op mijn vermoedens in die richting uit te spreken, opdat zij door anderen in hun juistheid of onjuistheid nader getoetst kunnen worden. Persoonlijk meen ik, dat Oedjoeng Galoeh in den tijd van Çrī Widjajaloka en van Vorst Erlangga (dus ca. in de $10^{\mathrm{e}}$ eeuw A. D.) zal blijken een andere naam te zijn voor het huidige Ujong Ta nah, het Hujungmedinī der Nāgarakrětāgama (zie boven blz. 94), het Ji-lo-t'ing van Chau Ju-kua uit 1225. En evenzeer vermoed ik, dat Warigaloeh, alias Warihgaloeh (zie V. d. Tuuk, 1.c.), niets anders zal blijken te zijn als het Woerawari van Erlangga's manifest uit 928 Çaka. M. a. w. : ik vermoed, dat Oedjoeng Galoeh en Warigaloe h als staten naast elkaar op oud-Langka. (de Z.O.punt van het Maleisch Schiereiland), op Langkasoeka, bestonden in ca. de $10^{\mathrm{e}}$ eeuw A. D., zooals toenmaals $\mathrm{Djanggala}$ en Daha naast elkaar in opkomst waren op Oost-kJava».

Doch is dit bovenstaande niet meer dan persoonlijk vermoeden - waarbij dan Galuh ware te vertalen als òf * $\mathscr{F} u$ weel, of "Schat, (zie V. d. Tuuk's Wdb., IV, p. 745-746); vandaar weer "Prinses, Kleinood», zooals in 't OJ. en Jongjav. - , aan één ding twijfel ik niet: dat oer-Langka, het voor Maleiers nu mythisch gewordene Langkasoeka, het voor de Voor-Indiërs niet minder mythische $L a \dot{n} k \bar{a}$ van 't Rāmāyana, dus ook het echte Langkāpura= Ratna-pārāyaṇa (verg. V. d. Tuuk i. v. lëngkā, IV, p. 815) van het Oudjav. Rāmāyaṇa uit de $10^{\mathrm{e}}$ (?) eeuw $=$ Ratna-dwipa, niet terug te vinden is op Ceilon,

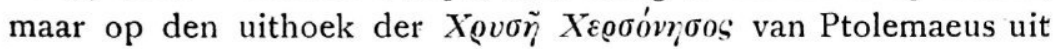
ca. 150 A. D. (I, $13: 8 ; 14: 1,3-6$; en $17: 4$; VII, $2: 5,12$, 25 ; en $5: 11$ ), het heusche $\mathrm{Su}$ v a ṇ ṇ a b h u mi ook uit ca. 450 van de Milindapañha (VI:21) en latere Indische geschriften; het Dl. 77. 
groote strategische punt voor de met circa Christus' geboorte opkomende zeevaart tusschen Zuidelijk Voor-Indië en TongkinZuid-China. Wanneer dan ook de "Reuzens-Vorst Rāwa n a in den aanhef van Zang 6 van 't Oudjav. Rāmājaṇa, naar de posthume vertaling van Prof. Kern (Bijdr. Kon. Inst. 73, 1917, p. 472), zegt:

«Mijn koningsburcht staat bij de zee, op Lankā, weidsch als de glans der maan. Het (eiland) [liever: (land)] heet eveneens Ratnapārāyaṇa (= Ratnadwipa) wegens de menigte van schitterende edelgesteenten»(VI: 1$)$,

dan is dat, in oorsprong, niet gedacht en gedicht van een plaats als Galle of Colombo of Trinkomali, maar m. i. van het "emporium

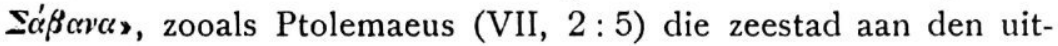
hoek der Aurea Chersonesus noemt; welke, herinnerend aan de $16^{\text {e }}$ eeuwsche Straat Sabang (Sabam, Sabão; later corrupt "Saboen.; tusschen Sumatra's Oostwal en het eiland Koendoer beZ. Karimoen), òf moet zijn geweest oud-Karimoen, ò oud-Hasin, of - en éérder m. i. - oud-Galoeh $=$ heusch-Langka.

Vanzelf vloeit daaruit voort - het moge mij vergund zijn, mijn persoonlijke opvattingen nog wat voort te zetten, die anderen mogen aanvaarden onder beneficie van inventaris -, dat m. i. die Reuzenvorst Rāwaṇa voor de Javanen en HindoeJavanen der $1^{\mathrm{e}}$ tot minstens $10^{\mathrm{e}}$ eeuw A. D. niet een litteraire luchtverheveling was, maar een realiteit. Die Havenkoning die daar heerschte op den vasten wal, achter de Selat Těb̌rau en achter het eiland Singapore, met het eiland Bintan tegenover zich in 't Zuiden, zat daar als ideale Selat-, d.w. z. "Straat»-roover te wachten op de schepen die van Indië voeren naar Tjampa, Kambodja, Tongkin, en die van daar, of later ook rechtstreeks uit Zuid-China (Canton, Chüan-Chou, enz.), terugvoeren naar Ceilon, naar Quilon (Kollam), naar Negapatam, enz. Hij had de sleutels, niet van den Hellespont, of de Zuilen van Hercules, of van den Sond, of van 't Kanaal, maar van de S elat nabij Singapore, en die tusschen Kaap Romania en 't eiland Bintan. Vobrdat $\mathrm{Kan}-\mathrm{da}-\mathrm{li}=$ later Palembang, in ca. 460 aanraking zocht met Keizer Hsiau-wu der $1^{\text {e }}$ Soeng-dynastie (zie Groeneveldt, Notes, 1876 , p. 60 ; of 1887 , p. 185), vóórdat Mo-1o-yu = later Diambi, in ca. 500 à 600 den blijvenden lands- en taalnaam zou geven aan de "Maleiers", - lag daar een Roofstaat èn Handels-staat 
Lang-ga of Lang-ga-su(-ka) op de plek die de Chineezen een 10 eeuwen later ook wel U-tang-ta-lim, alias Djiu-hut noemden, dus: Oedjoeng Tanah, alias Djohor; al was dit verband tusschen de Annalen der Liang-dynastie (502-556) en die der Ming-dynastie (1368-1643) bij de Chineezen in ca. 1550 uit het bewustzijn verdwenen (zie Groen. p. 10-12 en 135; of p. 135138 en 254). Een staat van prae-Maleiers zonder twijfel!

Want niet alleen, in ca. 500, "The people say that their country was established more than 400 years ago» (Groen. p. 10; of 136), maar in 515 A. D., zond hun Vorst Pa-kada-to, d.w. z. een heusche Maleische Datoek, een gezant naar het Chin. hof, terwijl diezelfde Datoe geboren was uit een huwelijk door zijn tijdelijk verbannen vader in Voor-Indië («India») gesloten (ib.). Hier hebben we dus in 515 A. D. een Voorindische halfbloed, die "als Vorst fungeert" (paka-datu) over Langka, en tegelijk een Boeddhistisch-Brahmanistisch ${ }^{1}$ politiek oogje werpt naar het machtige China, waarbij hij zijn gezant laat verzekeren: «it was my intention to come myself, but I was afraid that the storms and waves of the large ocean would make this too difficult, (1.c. p. 11, of 137). Dit is taal voor een Maleischen Datoe, die in 515 op Oedjoeng Tanah leefde, heerschte, roofde!

En is dit juist, dan eischt ook de consequentie - naar Dr. Krom mij terecht opmerkte - in het Mahāyānistische La ñ kāvatāra-sūtra (waarvan het bestaan vóór $443 \mathrm{~A}$. D. zeker is, door de Chin. vertaling uit dat jaar) niet te zien ceinen Bericht über den wunderbaren Besuch des Buddha Šākyamuni bei Rāvaṇa, dem König von Lan̉kā (Ceylon),, zooals Prof. Winternitz in zijn Geschichte der ind. Litteratur (II, 1: Die Buddhistische Litteratur, 1913, p. 243-244) verklaarde, maar een gefantaseerd godsdienst-verhaal van Boeddha's bezoek aan $\mathrm{Langka}=\mathrm{Hu}$ jung Galuh = Oedjoeng Tanah, halfweg Voor-Indië en China.

In dit verband nu zou ik willen vragen de pp. 90-93 te herlezen, die Prof. JACOBI in zijn standaardwerk van 1893 "Das

1 Deze slimmerik roemt zoowel de San-pau Tri-ratna, die in China zouden heerschen, als dat hij den Chin. Keizer vergelijkt met, the ruler of the heaven of Brahmâ"; ook vleit hij den Keizer, door van Z. M. te zeggen: ,The precious Sanscrit is generally known in his land. The walls and palaces of his imposing eities are high and lofty, as the mountain Gandha Mâdana [ook in 't Oudjav. Bhāratayuddha en Korawāẹrama overgenomen: Gand hamādana, eigennaam v. e. berg, V. d. Tuuk, IV, p. 635a, 642a]." - Zocht deze Maleier-Vorst den steun van China tegen de opdringende Voor-Indiërs? 
Ràmâyana. Geschichte und Inhalt nebst Concordanz der gedruckten Recensionen» gewijd heeft aan een onderzoek der ligging van Lañkā, die zoo bitter weinig past bij Ceilon; der oudste benamingen van Ceilon (Tāmraparnī, Táprobănê; Siṃhala, Salikê; maar niet Lan̉kā); en der herkomst van den naam (die géén Sanskrit is, maar door Jacobi vragenderwijs als «echtes TeluguWort, wordt ondersteld, p. 93). Nu in 't bovenstaande houvast werd verkregen door de Chin. berichten der Liang-dynastie èn de daarbij goed aansluitende aanwijzingen voor latere tijden uit andere bronnen, omtrent de heusche ligging van Lang ka tusschen ca. 100 en 600 A. D., is het zeker verrassend bij Jacobi een paar zinnen te herlezen als deze: «Die [indischen] Astronomen verlegten Lankâ auf den Äquator [sic; Oedjoeng Tanah ligt $1^{\circ} 20^{\prime}$, Galle $6^{\circ} \mathrm{N}$. Br.], wo er von dem ersten Meridian (dem von Ujjayinî $[=\mathrm{Ujjain}]$ ) getroffen wird. Kein Astronom in Ceylon hätte danach seine Heimat mit Lankâ identificiren können» (p. 90).

VARĀHAMIHIRA (†587 A. D.?) noemt in zijn Bṛhat-Saṃhitā van ca. 535 (kort na Langka's intrede in de Chineesche historie dus), Cap. XIV: 11, van de landen «in het Zuiden» alleréérst: Lankā; en, nà tal van andere landen, in vs. 15 : de $\mathrm{Simphala-eilanden.}$ In de vertaling van 1871 door Prof. KERN in Journ. R. A. S. ging dit onderscheid verloren, doordat hij Lan̉kā vertaalde met « Ceilon »; maar bij vs. 15 teekende hij in een noot aan: «It is strange here to find Sinhala after the occurrence of Lankâ in v. 11.» (p. 84). Als Arryabhata, iets vroeger dan Varāhamihira, in 499 reeds den eersten meridiaan trekt over Ujjayinī-Lańkā, en dan zegt dat de meridiaan van Rome $90^{\circ} \mathrm{W}$. daarvan lag, dan. komt dat slecht uit èn voor Ujjain èn voor Lańkā $=$ "Ceilon» (Rome $12 \frac{1}{2}^{\circ} \mathrm{O}$. L. Gr.; Galle $80^{\circ}$ O.), maar klopt (toevallig) goed met "Lan̉kā" = Oedjoeng Tanah; waarvan $\mathrm{Yavakoți}=\mathrm{Koetei}$ dan $90^{\circ} \mathrm{O}$. verwijderd lag, wat weer leelijk uitkomt voor beide. ${ }^{1}$

Hierbij zal ik het laten, want dit is een punt voor nader onderzoek door deskundige Indianisten. Maar ik voor mij ben volkomen

\footnotetext{
1 Zie voor deze gegevens de herdrukken thans in Prof. Kern's Verspr. Geschriften: I (1913), p. 235, met noot 6, en IV (1916), p. 77, voor Varāhamihira; V (1916), p. 308, en VII (1917), p. 59-60, voor Aryabhața. Ptolemaeus, die in ca. $150 \mathrm{~A}$. D. zijn eersten meridiaan trok over de Canarische eilanden (ca. $15^{\circ}$ W. L. Gr.), stelt Sábana (zie hiervóór blz. 98) op $160^{\circ}$ (Oost), en $2^{\circ}$ Zuid.

Galle ligt precies: $6^{\circ} 1^{\prime}$ N.Br., $80^{\circ} 14^{\prime}$ O.L. Gr.; Colombo: $6^{\circ} 56^{\prime}$ N., $79^{\circ} 56^{\prime}$ O.; Trinkomali : $8^{\circ} 33^{\prime} \mathrm{N}$., $81^{\circ} 15^{\prime}$ O.; Ujjain: $23^{\circ} 9^{\prime}$ N., $75^{\circ} 43^{\prime}$ O.; Oedjoeng Tanah: $1^{\circ} 20^{\prime}$ N., $104^{\circ} 15^{\prime} \mathrm{O}^{\prime}$; Koetei: ea. $0^{\circ} 30^{\prime} \mathrm{Z} ., 117^{\circ} \mathrm{O}$.
} 
gerust met te durven zeggen: La ṅkā was in ca. 100 A. D. volstrekt niet "Ceilon», maar wel degelijk Oedjoeng Tanah, waar men «den hoek omging» naar het raadsel-rijk van China.

Vrage zelfs: heeft de naam van den rākṣasa-Vorst $\mathrm{R} \bar{a}$ wa ṇa, die immers eerst "Tien-kop» of "Tien-mond» heette, totdat Çiwa hem dien onvertaalbaren(!) naam gaf, ${ }^{1}$ niets uit te staan met de

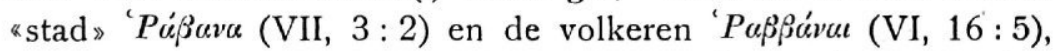
die bij Ptolemaeus àchter (d. w. z. benoorden van) de Gouden Chersonesus, in de "Groote Golf», en vóór het land der "Sinai», worden vermeld; ergens dus in Kambodja; waar allerlei Anthropophagen en Satyrs heetten te huizen? Is Rāwạ̣a niet een onkwetsbare "duivel» uit dat land van, en achter, Lañkā?

Hoe prachtig komen nu ook de gegevens tot hun recht in I-TSING's tweeden arbeid uit ca. 692, 2 te Palembang ook opge-

1 Wel heet het in het posterieure VII B Boek der Rāmäyana - het slot, of Uttarakāṇḍa--, Sarga 16, dat Çiwa den naam gaf aan $R \bar{a}$ wa ṇa, ,omdat hij zoo schreeuwde" bij cen daad die Çiwa hem verboden had en welke hij toch trachtte te bedrijven, zoodat dan Rāwaṇa = "Schreeuwer, Schreeuwleelijk" zou zijn - verg. Jacobi, 1893, p. 192; en voor de analoge Oudjav. lezing V. d. Tuuk's Kawi-Wdb. I, 1897, p. 753a i. v. Rāwaṇa -, maar dit is een soort lucus a non lucendo. Dr. Krom verschaft mij daarover de volgende aanteekening: „R $\mathrm{a} w$ an a is een zuivere afleiding, volgens alle regelen der kunst, van Skr. rū. Het beteekent dan echter niet "schreeuwend", maar: doende schreeuwen. Die Uttarakāṇạa-verklaring is om er op toe te geven." Dat zoowel het $\mathrm{I}^{\circ}$ (Bālakāṇḍa) als het laatste en $\mathrm{VII}^{\circ}$ Boek der Rāmāyaṇa latere toevoegsels zijn tot het oorspronkelijke werk, daarover zijn Indianisten het eens; zie het hoofdstuk „Echtes und Unechtes im Rāmāyaṇa" in Winternitz' Geschichte der indischen Litteratur, I, $2^{\circ}$ Ausg., 1909, p. 423 vlg.

In het IVe Boek wordt Sarga $40-43$, met de vermaarde 4 Ontdekkingstochten, door Rāma aan de apen gelast om resp. in het O., Z., W. en N. naar de verdwenen Sītā te gaan zoeken, door J $\mathrm{JCOB}_{\text {( }}$ (o. c. p. 37-38), evenzeer voor een later inschuifsel verklaard, evenals tal van andere welke hij in de oorspronkelijke Boeken II-VI nauwkeurig aanwijst. Winternitz (l. c. p. 426) acht deze aanwijzingen van Jacobi ,unwiderleglich". Daarmede ontvalt ons helaas ook het vertrouwen op een mogelijke juiste dateering van dat voor den Indischen Archipel zoo uiterst gewichtige vers 30 van Sarga 40 in dit IV• Boek, met de lastgeving om óók "Yavadvīpa" en "S uvarnarü pyakadvipa" (het Goud-en-Zilver-eiland) te gaan doorzoeken (zie Prof. Kern's studie uit 1869, thans in zijn Verspr. Geschr. V, 1916, p. 303 vlg.).

2 I-tsing's werk, door Takakusu vertaald (1896), heet: Nan-hai-chi-kueinai-fa-ch'uan; dat door Chavannes vertaald (1891): Ta-t'ang-si-yuku-fa-kao-sêng-ch'uan. Hij leefde van 634-713. - Takakusu, p. LI en tekst p. 9, gaf als transcriptie (doch zonder Chin. karakters): Lankasu; Chavannes (met Chin.; p. 57-58, noot 5): Lang-kia en Lang-kia-chou; Pelliot (met Chin.; BEFEO, IV, 1904, p. 406): Lang-kia-chou; Gerini (met Chin.; Researches, 1909, p. 544): Lang-ka-hsü. 
steld, en door E. Chavannes in 1894 vertaald als "Mémoire composé à l'époque de la grande dynastie T'ang sur les religieux éminents qui allèrent chercher la loi dans les pays d' Occident»! Daarin is Lang-kia (-chou; zóó Chavannes) het land, dat men per koopvaardijschip bereikte uit Fou-nan (= Kambodja; niet "le Siam», zooals de vroegere opvatting was, ook bij (havannes); waar een misschien Boeddhistisch Vorst regeerde, die Chineesche Boeddh. pelgrims met eere immers ontving (aansluitend dus bij wat 2 eeuwen te voren, blijkens de Annalen der Liang-dynastie, er ook reeds het geval schijnt te zijn geweest); en vanwaar men per schip verder ging, om dan Ceilon te bereiken (o. c. p. 57-59). Een andere Chin. pelgrim van de 60 , wier religieus leven I-tsing in dit Gedenkschrift verhaalt, gaat ók den zeeweg, komt in het land Lang-kia, passeert het land Ho-ling (= Kaling = Java; dus wel door Straat Soenda?), en gaat door het Land der Naakten (Nikobaren) naar Tan-mouo-li-ti (= de groote haven Tamlūk, aan den Z.W. mond van den Ganges, Tāmralipti; o. c. p. 100). Van een derden pelgrim $\left(n^{\circ} .37\right.$ van de 60$)$ wordt alleen gezegd, dat hij op zijn (zee-)reis van China naar 'l' Inde du centre, kwam te overlijden in het land Lang-kia-chou (p. 78). Deze gegevens alléén reeds weerspreken de meening van CHAVANNES (p. 57, noot 5) dat Lang-ka-su van I-tsing identiek zou wezen met het Kia-mo-lang-kia= Kāmalañkā = Pegoe van Hiuentsang (die overland Indië bereikt had, en overland in 645 China weer had bereikt); weerspreken ook de latere opvatting van GERINI (Asiat. Quart. Review, 1901, I, p. 157-158 noot; Researches, 1909 , p. 115, 527, 544), dat dit de tegenwoordige Chumpazen Baai op de Oostkust der Chersonesus zou wezen, $10^{\circ} 28^{\prime} \mathrm{N}$. Br., waar men dan aan wal zou zijn gestapt, den smallen Kra-pas zou zijn overgetrokken, en dan op den Westelijken overwal weer scheep zou zijn gegaan op een ander vaartuig. Dit is, om Gerini's woorden uit 1901 te gebruiken, "all mere guesswork». Op ongezochte wijze wordt daarentegen alles duidelijk als men Langk a-s u neemt op dien uithoek, waaraan ók Polo in 1292 voorbijvoer op zijn reis van Zuid-China naar Indië, en toen zeide dat hij daar aan het wilde eiland "Pentam» = Bintan was voorbijgekomen. GroeneveldT, die het in 1876, aan de hand van een deel der Chin. geografen, zocht "on the north coast of Java, but in the western part of the island. (p. 12; of 1887, p. 137), is er dus het dichtst bij geweest; een ander deel der Chin. geografen 
zocht Lang-ga of Lang-ga-su op... Ceilon; steeds weer dezelfde historische fout! I-TSING noemt, in zijn beide teksten van 692, Ceilon: Sêng-ho-1o, d.i. Siṃhāla, het «Leeuwen-land», en beweert alleen foutief in zijn Nan-hai (ed.-Takakusu, 1896, p. 9-10), dat óst van Lang-ka-su lag het land $\mathrm{Tu}-\mathrm{ho-}$ po-ti $(=$ Dwārawati $=$ Siam), en oost daarvan weer Lin-i $(=$ Champa, Mahācampā) $; \ldots$ precies dezelfde oude fout als reeds bij Ptolemaeus voorkomt. Immers, deze waande evenzeer hier in dien uithoek "Oost, wat Noord was. ${ }^{1}$

Langka, modern-Jav. Ngalěngkå (d. i. ing Alengkå), en Ra w a ṇ a, de "Reuzen»- en "Duivelen »-Vorst, waren, naar mijn persoonlijke stellige overtuiging, géén litteraire fantasieën voor de oud-Javanen tot, zeg, 1200 A. D., maar realiteiten. Daar lag een land, een Schier-eiland als appendix van Azië's vasten èn Indischen wal, waarmeê men, evenals met het reeds in ca. 600 machtige Palembang, vechten moest om de hegemonie ter zee. Vandààr «ergens» (Noord bij Pegoe? Midden bij Kellang? Zuid bij Singapore?, met nog heden ten dage de «Kallang river, of soengai Kālang in het $\mathrm{N}$. O. uiteinde der stad, ${ }^{2}$ bij Tanjung Ru) kwamen de geheimzinnige Kalang's, gewis krijgsgevangenen van den Overwal; die het alleréérst voorkomen op de Prambanan'sche inscriptie van 785 Ç. (Pereng; sang tuha kalang, Tijdschr. Bat. Gen. XVIII, 1872, p. 96), en later ; ${ }^{3}$ altemaal de latere met "honden" in verband gebrachte menschen der Jongjavaansche folklore. Maar wat kan oorzaak zijn geweest, dat daar in ca. 820 C. - zeg in ca. 900 A. D., dus bij den aanvang van de periode, die hier nader ten aanzien van Singapore en het verdere Mal. Schiereiland beschouwd wordt - plotseling dat complex van Prambanan-tempels gaat verrijzen onder den overgangs-

$1 \mathrm{Zie}$ voor Ptolemaeus de gegevens omtrent Oost-Azië op gemakkelijke wijze afgedrukt, met vertaling, door CoEDÈs in zijn „Textes d'auteurs greos et latins relatifs à l'Extrême-Orient depuis le IV• siècle av. J.-C. jusqu'au XIVe siècle", Paris 1910; en achter p. XXIV Pt.'s kaart, ed. 1478. - Voor Tu-ho-(luo-) po-ti in I-tsing's beide teksten, zie Chavannes l.c. p. 57-58 noot 5, en 69 .

- Verg. ook het interessante opstel van Logan, "The Biduanda Kallang of the river Pulai in Johore" (Journ. Ind. Archip. I, 1847, p. 299-302), en het daarop volgende "The orang Sletar" (p. 302-304) - de S. Sěletar is een inham in het N.N.O. van 't eiland Singapore -, welke Logan acht "to be branches of one tribe, the aborigines of Singapore" (p. 302).

- Het oudere sang pu kalang in een Noord-Kĕdoe'sche inscriptie van 775 Caka (Oudjav. Oorkonden, ed. Brandes-Krom, 1913, p. 7, r. 10) is, naar pers. meded. van Dr. Krom, het "slot van een eigennaam van een Ambtenaar". 
Vorst tusschen Midden-Java en Oost-Java, DaKsha? ${ }^{1}$ Op welke tempels zich immers alleréérst het wajang-type gaat vertoonen in de overdreven-verwrongen gezichtstrekken der "boozen» die daar een rol spelen op de Rámäyana-reliefs; evenals een 4-tal eeuwen later - in de eerste halve eeuw der Madjapahit-periode aan de talrijke Rāmājana-reliefs van Tj. Panataran! ${ }^{2}$ Gelooft men heusch, dat op deze twee machtige tempelgroepen van het stervende Midden-Java, en het "gearriveerde» en onbetwist-oppermachtige Oost-Java, enkel en alleen litteratuur werd afgebeeld?

Geloove wie het wil. Ik voor mij ben overtuigd, dat er, bij het toenemen onzer feiten-kennis van Java's oude historie, naast de louter-religieuze monumenten van bouwkunst en letterkunst, een groote groep politiek-religieuze gedenkteekenen allengs te onderscheiden zal zijn, die zelf weder vrij scherp in 2 categorieën zal gesplitst moeten worden: $1^{\circ}$. monumenten die \& Broedero orlogen, vereeuwigden, dus binnenlandsche dynastie-oorlogen, waarbij men met waren hartstocht teruggreep naar het schier oneindige Mahābhārata in zijn vele geledingen, en dààrin zich zelf en zijn eigen geschiedenis terugvond, en dààrop veranderende doorging en dààrop doorgaande veranderde - de feitelijk-legitieme maar verliezende Kaurawa's $=$ de laatste dynasten van Midden-Java; de overwinnende usurpators, die Pāṇdawa's heetten, $=$ de eerste oppermachtige koningen van Oost-Java, vóóral die van Daha - ; en $2^{\circ}$. monumenten die «Buitenlandsche oorlogen, in beeld of in dicht brachten, waarbij men als het ware het zooveel beknopter Rāmāyaña maar behoefde... om te werken, om zijn eigen angst-oogenblikken door en vooral zijn glorierijke triomfen over die "Vreemde Duivels" als in een spiegel weerkaatst te zien. Java zit vol, in zijn plaatsnamen, persoonsnamen, koningsnamen, titels, van heugenissen aan dien grooten broedertwist, waarmede het Bråtåjoedå en het grootste deel der wajang dagelijks nog den Javaan van tegenwoordig, hoog en laag, doordrenkt; ${ }^{3}$

1 Verg. in Bijdr. Kon. Inst. 74 (1918), sub 4, mijn: „Rijksbestierder-Vorst Daksha, en Tjạ̣di Prambanan; ca. 820-840 Çaka" (p. 151-163).

3 Het jaartal op een grooten bovendorpel, die waarschijnlijk bij den hoofdtempel hoort, is: 1245 Çaka (zie Oudheidk. Verslag 1915, p. 69); de 4 groote Kāla-beelden, elk met 1269 Ç., zitten aan den onderbouw vast. - Zie thans Dr. N. J. Krom's Inleiding tot de Hindoe-Javaansche kunst, 1920, II, p. 157, 165.

${ }^{3}$ Men doorloope slechts Cohen Stuart's „Alphabetisch Register van eigennamen uit de Jav. en Indische letterkunde", behoorend bij dl. I van zijn standaard-uitgave der Jong-Jav, Bråtå-Joedå (Verh. Bat. Gen. XXVII, 1860). 
een lichte stroom, hoofdzakelijk in plaats- en riviernamen en losstaande feiten thans nog herkenbaar, heeft daar-tusschen-door gevloeid, die de kleur vertoonde van het Rāmāyaṇa, maar zijn oorsprong vond in eigen levensgebeurtenissen tegenover buitenlandsche vijanden. Een verhouding, ruwweg geschat, van 10:1. Maar óók hieraan houden sommige grootsche bouwmonumenten, als met name Prambanan en Panataran, alsmede een groot deel van de wajang gedog met haar Pandji-cyclus, de heugenis hoezeer dan ook verlitteraird en daarmee verduisterd - nog in leven tot op dezen dag. De Kawi-tekst van het Bhāratayuddha draagt daarbij een jaartal: 1079 Çaka, en noemt een bepaalden Vorst: Djajabaja van Daha (Kẹdiri); de vrije Oudjav. omwerking van het Rāmāyaṇa mist niet alleen een jaartal, doch de schatting van haar ouderdom loopt zoo ver uiteen als de $9^{\mathrm{e}}$ dan wel $10^{\mathrm{e}}$ Çaka-eeuw volgens Brandes, de $12^{\mathrm{e}}$ C aka-eeuw daarentegen naar Prof. Kern; d. i. resp. de Sindok-Airlangga-, òf de laatste Daha-periode. ${ }^{1}$

Ik moet hier ook gaan spreken over een veel specialer onderwerp: de Javaansche oepatjara of Rijks-ornamenten. Gelooft men heusch, dat dit in oorsprong fetisjistische diervormen zijn; zoodat de Gans een totem-dier, de Slang een slange-fetisj zou wezen; enz.? Neen, óók dit zijn realiteits-symbolen geweest, allengs door vergetelheid in den loop der eeuwen tot fetisjen verworden. Den sleutel tot de historische, d. w. z. reëele, verklaring vindt men, zoodra men zich scherp te binnen brengt hoe Vorst Erlangga altijd weer die overheerschende figuur! - zijn symbool, den Garoeḍa, heeft gekozen; en hoe hij zichzelf, tronend als een overwinnende Wisjnoe, heeft laten afbeelden. Want wij bezitten zijne effigies, zie slechts zijn sprekend beeld bij 't artikel van Dr. Krom «De Wiṣnu van Bělahan» (Tijdschr. Bat. Gen. LVI, 1914 , p. $442-444) ;{ }^{2}$ daar zit hij met volstrekt-onconventioneel,

1 Zie resp. Dr. Brandes in de Monographie-Singasari \& Panataran (1909), p. $14^{*}$ (in de Wolkentooneelen van Panataran): „Het veiligste zal wel zijn aan te nemen, dat het boek [het Oudjav. Rāmāyaṇa] geschreven werd in het tijdsverloop tusschen deze beide groote Javaansche vorsten [Mpoe Sindok en Airlangga]." En Prof. Kern in zijn tekst-uitgaaf van 't Räm. (1900), p. VI: "Gissenderwijs zou ik als tijdstip der vervaardiging het begin der $13^{\mathrm{e}}$ eeuw [versta: A. D.] willen stellen". Zie voorts Dr. Krom's studie „Over de dateering van eenige Kawi-geschriften" (Tijdschr. Bat. Gen. LVII, 1916), p. 513 en 516-517; alsmede blz. 117 hierna, over het jaartal van 't Bhāratayuddha.

${ }^{2}$ Zie thans vooral: de plaat bij p. 39 in W. Fruin-Mees, Geschiedenis van Java, I (1919); en plaat 42 , met p. $409-411$, in Dr. Krom's Inleiding tot de Hindoe-Javaansche kunst, 1920, I. 
integendeel zeer naar werkelijkheid weergegeven persoon - een verfijnde Javaansche koeli zou men zeggen, ${ }^{1}$ met klambi en kain pandjang gekleed - op een lotuskussen, waaronder een geweldige, heraldisch naar rechts ziende, Garoeḍa-mensch met opengesperden bek zich als zijn hoeder uitbreidt in volle breedte van zijn vogelvlucht; en welke mensch-achtige Reuzenvogel weer in zijn rechterklauw omvat houdt een naar rechts gewende Brilslang, met een tweede dito-Nāga naar links gewend onder zijne linkerknie. D. i.: twee stuks Ardawalika, of "Prima-Gif»-slangen. ${ }^{2}$

Hier hebben we, uit het eigen leven van den Oudjavaanschen dynast zijn gróótste geschiedenis in beeld, een tjandra sengkala van realiteit en beeldhouwkunst: zijn Overwinning, vurig Wisjnoeiet die hij was, als "Wisjnoe» over de Slangen; d. w. z.: de Koningen der Waterslangen, der Slangen van Overzee. Het is de gróte triomf van hem die zich "Water-slurper, noemde, wiens vader (Oedajana) in 899 Çaka $=977 \mathrm{~A} . \mathrm{D}$. een "nāga-monument» stichtte te Djalatoeṇda $=$ "Water-terras ${ }^{3}{ }^{3}$ en die zelf in ca. 1045 A. D. begraven werd te Tirtha= ${ }^{\text {THeilbad }}{ }^{4}{ }^{4}$ op de O.-helling van zijn zóbzeer geliefden berg $\mathrm{P} \overline{\mathrm{u} g a w a t}=\mathrm{Putjangan}=$ den Pennanggoengan; van hèm, als Wisjnoe-Garoeḍa, over de Slangenvorsten van... Wurawari en Hasin, in Langka, over den "Primus der Gifslangen» (Bahlikādhipa; verg. V. d. Tuuk's Wdb., I, p. 500 sub "anggara»; en IV, p. 837b; =Wāhlikādhipa $=\ldots$ Arddha-wa(h)lika!), aan het uiteinde der Chersonesus van "Goud» en "Edelgesteenten» (Galuh). Kortom: de slot-triomf van Oost-Java over Woerawari vooral, dat eerst zelf Java "overstroomd, had met oorlog en ellende, maar door Erlangga in 1032 A. D. was geveld als overwalsche geweldenaar.

Zóó vinden we den Garoeḍa en de Ardåwalikå als zij het niet meer bewust gebleven - symbolen terug onder de

1 Dr. Krom maakte mij opmerkzaam: „De Erlangga van Bĕlahan is in zijn gelaat niet geheel oorspronkelijk; er is wat aan bijgewerkt, met name aan den neus. Op de foto ziet men dat niet.” - Verg. nu in zijn Inleiding: „Wishṇoe's gelaatstrekken (in geschonden toestand bewaard en helaas wat bijgewerkt)".

2 Zie het artikel van Dr. $\mathrm{H}_{\mathrm{AZkU}}$ in de Bijdr. Kon. Inst. 6, V (1898), p. 175204: „De Nâga Arddhawalikka bij de Javanen”, en de daar op p. 201 in herinnering gebrachte meening van Prof. Kern uit 1887: „dat het een samenstelling zou kunnen zijn" van Skr. arddha $=$ zeer + vyalīk $a=$ valsch. Hazeu vermoedt een $a r d d h a+w a l i(=b a l i$; sterk) $+i k a$ (aanwijzend en versterkend) $=$ mahabala = zeer krachtig. Het Jongjav. schrijft zoowel arda, als arḍa.

- Zie daarover nader den hoofdtekst blz. 109-110, bij oepatjara $\mathrm{n}^{\circ} 1$.

- Dit oude Tìrtha is het tegenwoordige Bĕlahan (Krom l. c., 1914, 1920). 
8 oepatjara van het Solosche Hof; de Ardåwalikå ook nog (zònder den Garoedå, zònder dien Oostjavaschen Overwinningsvogel) aan de tweede-rangs oepatjara van het (secundaire) Jogja'sche Hof. Want ziehier het vergelijkend lijstje dezer $2 \times 8$, waarbij die van het Solosche Hof voor het éérst - incredibile dictu! - eens volledig genoemd worden:

\section{Solo.}

1. Banjak dualang (Gans-aanvoerder) [Deeleman $n^{\circ} .6$ ]

2. Ardåwalikå (Konings-slang) [Deeleman $n^{\circ}$. 3]

3. Gadjah (Olifant) [niet in Jogja; Deeleman $n^{0}$. 4]

4. Kidang (Hert, geslacht Cervulus) [Deeleman $n^{0} .5$ ]

5. Sawoeng galing (Vecht-haan) [Deeleman $n^{0} .2$ ]

6. Ga roe då (Slangengier) [niet in Jogja; Deeleman $n^{0}$. 1]

7. Memreng (Buffelkalf)

8. S ènoek (Tapir) niet bij Deeleman

\section{Fogja.}

1. Banjak dalang (letterlijk: Gans "de voorste»)

2. Ardåwalikå (letterlijk: "Aller-giftigste»?)

3. M ऍ rak (Pauw) [niet in Solo]

4. M Łndjangan (Hert, geslacht Rusa)

5. Sawoeng galing (letterlijk: «trippelende» Haan)

6.

7. (Surrogaat; 3 ampilan $^{1}$, tot oepatjara verheven)

8.

Alles van' goud; zoo het heet zelfs massief goud, hoezeer dat voor enkele stukken wegens de afmetingen toch te betwijfelen valt. De officieele volgorde der 5 (wezenlijke) Jogjasche oepåtjårå staat daarbij vast; men zie slechts Plaat $\mathrm{I}^{\mathrm{a}}$ en $\mathrm{I}^{\mathrm{b}}$ in Groneman's "In den Kedaton te Jogjakarta» (1888). De volgorde in bovenstaand lijstje der 8 Solosche is geheel onzeker, en door geen enkel gegeven tot heden vast te stellen; men zie slechts de altemaal ònvolledige bronnen dienomtrent in de noot, naar tijdsorde gerangschikt, waaruit bovenstaand volledig lijstje werd samengesteld. ${ }^{2}$ Geen van alle berichtgevers is zich het volle

1 N.l. De katjoe mas en de koeţoek, die beide straks (blz. 128, en 129 noot 1) ook vermeld zullen worden onder de ampilan van den Soenan; en een gouden lantaarn (kandil). Dit laatste woord ontbreekt in 't Jav. Wbd., 1901.

2 RAFrLes (History of Java, 1817, I, p. 310; sprekende over het Hof te Solo blijkbaar, en zijn bezoek daar in 1812 , sie toch p. 309) zag er maar 5 van de 8 , 
achttal bewust geweest; DeEleman, die in 1846 er 7 noemde en 6 afbeeldde, is er het dichtst bij gekomen, hoewel hij zich met zijn opgaaf van "twee gadjah» kennelijk heeft vergist, waarschijnlijk door af te gaan op inlandsche berichtgevers. Of opzettelijke terughoudendheid daarbij in het spel is te Solo - zooals ik uit eigen ervaring in 1888 weet ten aanzien van het kanon $\mathrm{Njahi} \mathrm{Sðtomi} \mathrm{op} \mathrm{den} \mathrm{Sitinggil,} \mathrm{dat} \mathrm{men} \mathrm{"geheim»} \mathrm{wil} \mathrm{houden} \mathrm{-,}$ dan wel of alléén bij zeer hooge feestelijkheden, zooals met name Garěbeg Moeloed in een jaar Dal, alle 8 Rijks-ornamenten te voorschijn komen voor het publiek, is thans nog niet te zeggen. Maar de volledigheid der lijst staat vast; het is het heilige getal 8 - waaraan het gaarne "ouderwetsch»-doende Jogjasche Hof angstvallig vasthoudt; zij het dan door toevoeging van 3 ampilan -, thans op de handen gedragen door 8 vrouwelijke prijaji manggoeng vóór den Vorst uit, maar weleer - daar behoeft want hij schrijft: „A Among the regalia (upachira), which are always carried in procession when the sovereign moves abroad, and are arranged behind him while seated on the dimpar, are the following golden figures: - the haisti or gája, that of an elephant; the hárda walika or nanigan, that of a serpent; the jajawen sainting, that of a bull; the singsam, that of a deer; and the saiwung giling, that of a cock fowl; each of a size to be borne in the hand." Daarna gaat hij spreken over de ampilan, zonder dit woord echter te noemen.

Winter (Tijdschr. v. N.-I., 5 jrg., 1843, I, p. 739-740) wart „Hoepotjoro" als ,teekens van onderscheiding" met de niet met name genoemde ampilan dooreen, en vermeldt voor den „Keizer" daarbij deze heusche 6 Rijks-insigniën : „Sauoong Galing, een gouden haan. Hardo waliko, een gouden vogel, met eenen slangenkop. Banjakdalang, een gouden eend. [Dan weer diverse ampilan; en dan:] Senookmas, een fabelachtig dier der oudheid, van goud, hebbende de gedaante van eenen Rinoceros. Memréngmas, een fabelachtig dier der oudheid, van goud, hebbende de gedaante van eenen buffel zonder hoorn. Een gouden hert. [Daarna weer ampilan.]" Dus géén Olifant van den Soenan; maar de Gans („eend") en Tapir („Rinoceros") méér.

DeElexan (waargenomen in Jan. 1816; na zijn dood afgedrukt naar zijn hs. en talrijke teekeningen in Bijdr. Kon. Inst. 2, II, 1859, p. 358) maakt duidelijke scheiding tusschen oepatjara en ampilan (evenals Raffles dus), maar noemt geen van beide woorden, omdat hij alle gelijkelijk poesaka's noemt. Van de „eersten", die „hooger bij de Javanen aangeteekend (staan), zoodat men ze dus beschouwen kan als meer in 't bijzonder de kenteekenen der keizerlijke waardigheid te zijn", somt hij deze 6 op: 1. pěksi groeḍå, 2. sawoenggaling; 3. arḍa warikå of arḍ̊a walikå, enkel verklaard als „een waterkom"; 4. twee [lees: één] gadjah; 5. kidang; 6 . banjak. Hij voegt toe: „Al deze voorwerpen zijn van massief goud". Bij hem dus de Garoeḍa vóórop, die bij Raffles en Winter ontbrak; maar geen Memreng of Sěnoek.

Tevergeefs heb ik in Winter's Jav. Zamenspraken, I (1 ${ }^{\text {en }}$ druk, 1848) gezocht naar een systematische opgaaf van de Solosche oepatjara en ampilan. Het eenige wat ik heb kunnen vinden is: in Zam. 30, dat de kĕmit's boemi 
men m.i. niet aan te twijfelen, al zou het bezwaarlijk gaan er een bepaalden tijd voor te noemen; soms in de $15^{\text {e }}$ eeuw A. D.? vóór Z.M. uitgedragen door 8 to e-manggoeng's (mannelijke Toemenggoeng's, Teměnggoeng's), of Hof-Dignitarissen, die thans in de 8 Najåkå's aan beide Hoven ( 4 "Binnen»-regenten + 4 «Buiten»-regenten) nog steeds voortleven.

De nadere behandeling van deze Jongjavaansche materie uitstellend tot tijd en wijle dat hierover, van Solo uit, goede gegevens verkregen zullen zijn, en ook eindelijk eens afbeeldingen van $\mathrm{n}^{\text {os }} 7-8$, het Buffelkalf en den Tapir, durf ik thans ook reeds deze conclusies vooropstellen:

1. De Gans-Aanvoerder, die bijna gewis ook in Solo vóórgaat aan alle 8, vindt zijn oudste herkenning in de 2 Gekroonde Ganzen, die als twee cijfers 9 aanzwemmen op den Triangel (het cijfer 8 ), op den muur van Djalatoeṇda, voornoemd ${ }^{1}$; een *nāga-

(een lage rang van Kaparak-ambtenaren) o. a. de „oepatjantěn dalěm” buiten den kraton brengen (p.83); in Zam. 62 het wel interessante, dat, bij de inhuldiging van een nieuwen Soenan, rondrijdend in zijn staatsiekoets (Kjahi Doeḍ̊) met den Regeerings-Commissaris buiten den kraton, vóór den Soenan uitgaan de Poetrå's, Sěntånå's en diverse keur-pradjoerit's, maar dat achter de koets gaan: eerst de oepatjårå dalěm (bedoeld zijn: 's Vorsten persoonlijke ampilan), vervolgens 's Vorsten rijpaarden, en daarna de ,ampilan ěmas banjak-ḍalang sapěnoenggilanipoen" (p. 261). Hier gaan dus de gouden Rijksornamenten achteraan in den centralen stoet, als symbool wel van het nog niet definitief-Vorst-zijn van den nieuwen Soenan. Hier ziet men tevens, hoe in het Jav. gespeeld kan worden met de termen oepatjara (= "versiersel") en ampilan (=,wat op de handen gedragen wordt").

1 Hierbij beschik ik over een foto uit Oct. 1916, mij door den heer P. V. vas Stein Callenfels toegezonden, terwijl men vroeger alleen kon afgaan op de (nu zeer onvoldoend gebleken) lithografie in Van Hoëvell's Reis over Java enz. II (1851), p. 110. Over de 6 kleine inscripties op 6 gouden plaatjes in een 9-vakkige graf-urn aldaar gevonden, zie Brandes' belangrijke noot in Groeneveldt's Catalogus (1887), p. 215-219; op grond van deze, meende Brandes, dat het hier in hoofdzaak een Çiwaïtisch graf-monument gold; Dr. Boscr kwam echter in Oudheidk. Verslag 1916, p. 84, na een nieuw bezoek ter plaatse (zie er p. 71), terecht tot de conclusie, dat „de Garuḍa-nāga-combinatie o. i. reden geeft te onderstellen, dat Udayana, evenals zijn zoon Erlangga, tot de secte der Wișnuieten behoord heeft".

De volle oplossing van die "combinatie" - "Garoeda boven" (genre Oranje boven!) + Arddhawalika (= Nāga) onder" -, in den hoofdtekst hier gegeven is een groote verbetering op wat ik in Notulen Bat. Gen. 1909, p. 184-185 met onvoldoende gegevens had beproefd. Opmerkelijk is, dat het gouden plaatje in den vorm van een schildpad - vrage: Wisjnoe in zijn 2e awatāra?: men vergelijke o. a de schildpadden te Soekoe - de legende draagt: $r$ am $=$ rang, dat volgens V. d. Tuuk (I, p. 816a en $819 \mathrm{~b}$ ) de betee- 
monument» uit 899 Çaka, gesticht in dat jaar op de W.-helling van den Pennanggoengan door Oedajana, den vader van Erlangga. Ook zijn naam "Udayana" staat er voluit aan den wand. Wat was dit? Een "nâga-tempel", zooals GROENEVELDT in 1887 naar Van Hoëvell's uitvoerige beschrijving uit 1851 vermoedde (Catal. Arch. Verz. p. 125)? Neen; een nāga-monument ter herinnering aan een triomf van den Wisjnoeïet Oedajana - misschien zelfs als Laksamana of Admiraal? - in 977 A. D. behaald òp de Naga's en hunnen Vorst, den Arddhawalika van Galoeh $=$ Langka $=$ Woerawari! En dààrbij weer, naar pers. meded. van Dr. KROM, sluit aan, dat Erlangga in zijn Sanskrit-inscriptie te Calcutta, memoreert hoe zijn overgrootvader van moederszijde door wien de Konings-wettigheid zich in hem, Erlangga, had voortgezet - te vergelijken was met eenen "rājahamsa», eenen "phenix der koningen (anders: den vorstelijken mannetjes-zwaan), volgens Prof. Kern's vertaling; anders ook gezegd: met eenen Zwaan den Voorste, of Gans den Voorste, eenen Banjak ḍalang, den drager (wāhana) van Brahmā.

2. De Konings-slang is ongetwijfeld het symbool van het lang bevochten, hoogst gevaarlijke, meermalen (waarschijnlijk), maar éénmaal (in 928 Çaka) gewisselijk over Java als overwinnaar heengestorte, doch in 954 Çaka toch door Erlangga overwonnen Woerawari. De Arddha-walika dus, overwonnen door den Garoeḍ a (zie verder bij 6 hierna). Vrage zelfs: was de in 1708 verdwenen Madjapahit-kroon niet een Nāga-makoeța ${ }^{1}$

kenis heeft van "terugtrekken van hoog water", verminderen (van een bandjir), en daardoor ook weer van rangrang = ijl, schaarsch, dun. Mag hier gedacht aan 't verdwijnen van een "vloed" van vijanden?

Den naam „Djalatoeṇda" vertaalt V. d. Tuuk (IV, p. 388a) als „water-sna vel” (Skr.); Brandes, l.c. p. 217, stelde het gelijk met Jav. p antj o e r a n; in aansluiting echter bij V. d. Tuuk's eigen „verdieping?" i. v. toeṇḍa (II, p. 570a), alsmede bij 't Jongjav., zal „Water-terras" wel den juisten zin teruggeven (een hybride dan als Air-langga). - De Garoeda is hier als waterspuier (beschermend!) aan den Noordwand, de nāga-kop als spuier an den Zuidwand (sĕlatan!), en op het Zuidelijk vak van den centralen Oostwand (waar de waterspuier helaas verdwenen is) staat aan den binnenkant met kolossale typen van 37 cM. hoogte het jaartal: 899 ; en haaks daartegenover op een vooruitspringende lijst in veel kleiner typen de naam: Udayana; zie Verbeek (1891), p. 241-242, Knebel in Rapp. Oudh. Ond. 1907, p 93, en Verbeek's Inventaris, 2 e ed. (1918), in Rapp. Oudh. Dienst 1915, p. 223-224 (alwaar in 't Voorloopig Register de naam „Penanggoengan" ontbreekt!). - Verg. thans vooral Dr. Krom's Inleiding tot de Hindoe-Jav. kunst, 1920, I, p. 51, 405-409; II, 197.

1 Valentijn (IV, 1726; 1 `Stuk, fol. 111b) beschrijft haar: ${ }_{n}$ Zeker Kapitein, die 
3. De Olifant te Solo, de Pauw te Jogja, schijnen louter Koningssymbolen. Opmerkelijk is zeker, dat de 2 oepåtjårå die de Solosche Kroonprins bezit, volgens de opgaaf van WINTER in 1843, zijn: een Gadjah mas; en "een gouden slang,, aldaar (o. c. p. 741) geheeten "Gardo waliki», wat wel als Krẹḍ̊åaliki of $\mathrm{Kroed} \mathrm{åmaliki} \mathrm{te} \mathrm{lezen} \mathrm{zal} \mathrm{zijn,} \mathrm{een} \mathrm{verheven} \mathrm{hof-term} \mathrm{voor}$ het antieke Arddhawalika. Aangezien echter de Kroonprins, blijkens zijn titel, de «Pangeran» is die als "Adipati Anom» fungeert (dus: Jonge Prins-Rijksbestuurder), zoo zou men toch meenen, dat in dezen Gadjah mas, dien èn Soenan èn Kroonprins als kĕprabon hebben, tevens een herinnering leeft aan den gróóten Rijksbestierder van Madjapahit, Patih Gadjah Mada.

4. De Kidang - var.: het gewone "Hert - schijnt een litte-

deze kroon gezien heeft, zeide my, dat zy de gedaante van twee dooreengeslingerde draken had, met de koppen na voren toe [sic], zynde van zuiver gewerkt goud, zeer sierlyk op zyn Manilha's [-in Manila-trant; sic] van dik draatwerk gemakkt, en met heerlyke paerlen en diamanten bezet."

Zie over deze makoeţa, door Troenadjaja naar zijn vorstenzetel Kĕdiri (Daha rediviva!) uit Plered (in Mataram) weggesleept, en daar, bij de verovering dezer opstandelingen-stad, ongeschonden aan kapt. François Tack op 25 Nov. 1678 in handen gevallen, en op Zo. 27 Nov. door den Soenan (Mangkoerat II) hoogsteigenhandig weer ter aloen-aloen op eigen hoofd geplaatst: De Jonge, Opkomst, VII (1873), p. LXXXI, 246, 249, 264 en VIII (1875), p. 332, en Veth's Java, $2^{\circ}$ ed., II (1898), p. 52-53; maar rooral daarnaast het authentieke over Tack's ongeloofelijke onbeschoftheid en dombeid om zichzelf die kroon ten aanschouwe van alle Javanen ók op het hoofd te zetten, zoodat de Soenan terecht kon beweren "dat nevens den Keijser nog een perzoon tot Cesar van Java gekroont geworden was" (zie Dr. DE HAAN in Tijdschr. Bat. Gen. XL, 1898, p. 336; waar echter De Haan een veel te aarzelende conclusie trekt). Tevens blijkt uit dit laatste bericht van 1733, dat wel degelijk een kostbare edelsteen in 1678 reeds an die kroon ontbrak, wat weer aanleiding gaf tot het verhaal bij Valentijn, l. c. fol. 111b-112a. En dat Tack's onbeschoftheid met de kroon geen praatje is, blijkt afdoend uit de voorstelling in de Babad Tanah Djawi, ed. 1874, p. 399, dat „kapitein Tack dikwïls een gouden kroon droeg" (,wondene kapitan Tak wahoe dĕdĕgipoen gagah prakosa, sarta asring ngangge makoeţa mas")!

De verdwijning van deze kroon in ca. 1708 blijkt uit wat $R_{\text {AFFLES }}$ schrijft in zijn History of Java (1817), I, p. 92: „Since the loss of the makota, or golden crown of Majapáhit, which disappeared on the banishment of Susinan Mangkirat, both the Susinan and Sultan, on public occasions, when they have to meet the European authorities, wear a velvet hat or cap of a particular fashion somewhat different at each court"; versta: de songkok. $\mathrm{Nu}$ werd Soenan Mas (- Mangkoerat III, 3 Dec. 1703-11 Sept. 1705) in 1708 naar Ceilon verbannen, en nam verschillende poesaka's van het Mataramsche Hof mede; waarvan in 1737 een deel, met 4 van zijn zonen, naar Kartasoera terugkeerde; zie toch Veth's Java, 2॰n druk, II (1898), p. 110-111, 113, en 129. 
raire(?) herinnering aan den "kidang met gouden haren" of den "gouden kidang" die een rol speelt in het Jav. Ramajana, om Rama en Laksjmana weg te lokken ten behoeve van den roof der schoone Sita door den aterling-Reuzenvorst DasamoekaRawana. Zie C. F. Winter's overzicht van den Råmå, in Verh. Bat. Gen. XXI, 2, 1846-47, p. 8-10 ; Dr. Juynboll's Glossarium op het Rāmāyaṇa, 1902, p. 124; en Prof. Kern's vertaling van Zang V van 't Oudjav. Rām. in Bijdr. Kon. Inst: 73 (1917), p. 168, vs. 38-45. Daar deze metamorphose van den "reus» Maritja in een "gouden reebok», daarop gedood door Rama, echter behoort tot den Rama-Rawana-cyclus, zal er wel een verborgen historisch feit in gesymboliseerd zijn. Soms - men vergeve mij de conjectuur, ter wille van de duidelijkheid - de oudste optredingen van Langka-vijanden op Java, nog in de Midden-Javaansche periode? Opmerkelijk in dit verband is zeker weer, dat V. d. Tuuk in zijn Wdb. i. v. tjamani ("zwart, neger-achtig»; I, 1897, p. 658) uit het al vrij jong-Jav. gedicht Moersada een plaats aanhaalt waarin van "oepatjara» alleen de Kidang èn de Ardawalika met name worden genoemd.

5. De Vechthaan lijkt mij voorshands een symbool van den grooten Vorst van Madjapahit, Hajam Woeroek, "het Hane-Jong "

6. De Garoeḍa is Erlangga's koninklijk symbool, het zegelmerk op zijn inscripties. Zijn heraldisch teeken, zoo goed als de Adelaar (Twee- of Eenkoppig) op de landswapens van Duitschland, Rusland, Polen enz., of St. Joris met den Draak bij de Kruisvaarders en nu nog op het Engelsche schild. Eenzelfden helschen "Draak» als de Kruisvaarders eenige eeuwen lang zich inspanden om te verslaan onder het aanroepen van St. Georgius (heiligendag: 23 April), moesten Midden- en Oost-Java bevechten van (zeg schattenderwijs) $800-1200$ A. D., in den vorm van het geweldige Boeddhistische (?) Langka-Woerawari-Hasin. En Java deed dit bij voorkeur onder het aanroepen en de hoede van Wisjnoe, den Zonnegod, die de Wolkenslang (Ahi), samen met Indra, bestreed; die als Overwinnende God op "boozen» reeds in de 4 e $-5^{\mathrm{e}}$ eeuw op West-Java de hoogste God der ingedrongen Hindoe's was; die van ca. 900-950 A. D. - getuige Prambanan - een hóogvereerde weder was in zijn $4^{\mathrm{e}}$ verschijning als Narasingha (ManLeeuw), zijn $7^{\mathrm{e}}$ als Rāma, en zijn $9^{\mathrm{e}}$ als Krěsjna; die Erlangga's grootste godheid was in de $11^{\mathrm{e}}$ eeuw A. D. op Oost-Java; en die, blijkens alle ons overgebleven gegevens in Kẹ̣iri, in het 
rijk Daha gedurende de $12^{\mathrm{e}}-13^{\mathrm{e}}$ eeuw, zoo in zijn verschijning als puur-Wisjnoe, of Rāma, of Krěsjna, de Hoofdgod is geweest van de daar regeerende dynasten. Hij, Wisjnoe, wiens rijdier was de "Garoeda, de slangendoodende reuzenvogel, eigenlijk de door de lucht vliegende, wolkenklievende bliksem». ${ }^{1}$ Gegeven eenmaal het feit dat men zijn verre vijanden overzee als "slangen * zich gaat voorstellen, die tien- of méér-koppig het land komen te bedreigen (Daçamukha-Rāwạ̣a c.s.), dan ligt het vervolg der symboliek voor het grijpen in Erlangga's tijd, met zijn zeemachtexpansie.

Dat Langka in ca. 900 A. D. Midden-Java, tijdens Daksha of kort vóór hem, ernstig is komen bedreigen, - de Prambanantempels spreken het m. i. uit in onmisvatbare taal; dat Langka, Lengkasoeka, toen wel was een Boeddhistische staat, is, aangezien alle aanduidingen uit I-tsing's tijd (ca. 700 A. D.) in die richting wijzen, méér dan waarschijnlijk; dat het complex der Drie-eenheid van Goden te Prambanan met den naar het Oosten gerichten Çiwa-tempel in 't midden, dien van Brahma in 't Zuiden, en dien van (den reddenden!) Wisjnoe in het Noorden - nota bene; iets als een Goddelijke beschuttende "Pangeran Ngabehi Lor ing Pasar»! ${ }^{2}$ - daar een triomf tevens beduiden op dien Boeddhavan-Overzee, ligt m. i. óók voor de hand.

Dat. Woerawari in 928 Çaka Java overstroomd heeft met onheil, is absoluut zeker. Geweldige weerwraak misschien voor wat Erlangga's vader, Admiraal(?) Oedajana, in 899 Çaka met zijn vloot(?) aan dat overzeesche oud-Djohor schijnt te hebben aangedaan. Weerwraak misschien óók voor een ouderen aanval van Java, in den tijd van Mpoe Sị̣dok (regeert ca. 850-870 Çaka) gedaan op het zuidelijkste deel van de Chersonesus, waarvan wij de voorshands nog onontraadselbare maar duidelijke sporen terugvinden aan weerszijden van de monding der goed bevaarbare Moear-rivier (sungai Muar; $2^{\circ} 3^{\prime} \mathrm{N} . \mathrm{Br}$.), die èn uit de Nāgarakrětāgama van 1365 A. D. bekend bleef als onderhoorig-

1 Deze zinsnede is ontleend aan een ongeteekend stukje „Wisjnoe" in dl. IV, $1^{\bullet}$ ed. (1905) der Encycl. v. N.-Indiö, dat echter in zijn zakelijken rijkdom kennelijk van de hand is van Prof. Kern. - Uit Prambanan is ook de $5^{\circ}$ awatāra (als Wāmana of Dwerg) bekend; over deze laatste zie hierachter noot 1 op blz. 125. De vereering voor Rāma en voor Krěsjna spreekt er in de talrijke reliefs aan resp. den Çiwa- en den Wisjnoe-tempel.

2 Zie het analoge bij Djalatoeṇda, blz. 110 hiervóór, het slot der noot; en verg. ook Bijdr. Kon. Inst. dl. 74 (1918), p. 161 met noot.

Dl. 77. 
heid van Madjapahit (Z. 14, 2: P a ka, M u w a r), èn voor het dichtbij gelegen Malaka $\left(2^{\circ} 11^{\prime}\right.$ N.Br.) in den lateren tijd steeds een schuilplaats is geweest dergenen die naar Malaka heen wilden of uit Malaka verdreven waren. ${ }^{1}$

En dat Galoe h in ca. 1050 Çaka, onder Vorst Kāmeçwara I of misschien iets later, in Djajabaja's tijd, in 1057 Çaka $=1135$ A. D.? - D a h a op den rand heeft gebracht van den ondergang, is met $95 \%$ waarschijnlijkheid thans óók aan te toonen. Daarvoor

1 Die duistere en desondanks duidelijke sporen zijn de volgende: op de Z.O. loopende kust tusschen de S. Kĕsang (N.W.) en de S. Muar (Z.O.), een eindje bovenstrooms van de monding der S. Kĕsang (waar het gebied van het „Settlement Malacea" ophoudt, en het landschap „Muar" als onderdeel van den inlandschen half-onafhankelijken staat „Johore" begint; $2^{\circ} 6^{\prime} \mathrm{N}$. Br.) bevindt zich, blijkens de Admiraliteits-Kaart No. 795 (1896; New ed., Aug. 1913), alsmede de door mij als detailkaart gebruikte kaart in 6 bladen: Map of the Malay Peninsula (1911; London, E. Stanford; uitgave der Straits Branch R. A.S.; schaal $1: 506.880$ ), een kampoeng Parit D ĕrhaka („Oproerlingengracht", Oudjav. droehaka, drohaka, vgl. V. d. Tuuk, II, 1899, p. 405a; Jongjav. doerâkă ; Mal. ook doerhaka, waarvan weer de nu verouderde Ned. zeemansterm doerak = beroerling); aan de kustlijn evenwijdig ongeveer, iets dieper het land in, als treesan die beide rivieren verbindt, loopt echter eene soengai Sendok! En aan den orerkant der S. Muar, in Z.O. richting, aan het eind van het langs de kust zich uitstrekkende landschap Padang, daar waar een moeras beZW. den Boekit Muar (hoog ca. 250 M.) gaat beginnen, ligt een thans nog in hoofdzak door afstammelingen van Javanen bewoonde groote plaats, die P a rit J a w a ("Javaansche gracht") heet! Het is door dit landschap Padang, dat tegenwoordig een spoorweg loopt van Bandar Maharani (de moderne handelsplaats "Koninginne-haven" aan den mond der Moear) tot de stad Parit Jawa, 8 Eng. mijl (13 K.M.) lang, evenwijdig aan die kustlijn; een landschap „peopled chiefly by Javanese" (Phillips, Bristol 1906, p. 107-108).

En tot slot van deze suggestieve feiten: nog wat verder Z. O. aan deze kust, een eind voorbij bovenbedoeld moeras, ligt op $1^{\circ} 49^{\prime}$, de monding van de Sungai Batu Pahat (of de "Rivier van den bebeitelden Steen", ook in de Sĕdjarah Malajoe, Verhaal 13, 31 en 32, genoemd; de Rio Formoso of "Mooie rivier" der Portugeezen), waarvan de even suggestieve naam totaal in het duister verblijft; doch waarvan wel dadelijk de zin zich zal ophelderen, zoodra men bij de kampoeng Batu (aan den $\mathrm{Z}$. mond), die voluit echter heet: Batu Pahat, eens naar een òf bebeitelden (dus: met relief voorzienen) òf veeleer beschreven steen zal willen gaan zoeken! Het geheele landschap aan dien stroom heet "Batu Pahat".

Volgens N. B. Dennys' „Descriptive dictionary of British Malaya” (1894, p. 393) zou er hoogerop aan de Muar-rivier nog een tweede Sungai Sendok als kleine rechterarm in de Muar vallen, $1 \frac{1}{2}$ Eng. mijl beN. de plaats Panchor of Panchur (Pantjoer). Op de genoemde twee kaarten vind ik dit niet bevestigd; het zou dan zoowat zijn tegenover de monding van de historische Sungai Pagoh (zie hiervóór blz. 27-28). Ook een dorp Sungai Sendok, door Dennys vermeld als „V[illage] on the Muar side of the Kessang R[iver]", 
heeft men eerst maar te kijken in een Javaansch Pandji-verhaal. Gemakshalve - Vreede's Catalogus van 1892 is nu eenmaal "wetenschappelijke revolutie-bouw", waar men alleen in nood zijn toevlucht neemt - leze men ROORDA's overzicht "De lotgevallen van Raden Pandji» (Bijdr. Kon. Inst. 2, VII, 1863, p. 1-65). Daar treedt in de $2^{\text {e }}$ helft (p. 44-65) op de machtige "Kellånå Toendjoeng-Setå», oftewel de "Titan Witte-Lotus», Vorst van het verre eiland «Kentjånå» (Ptolemaeus' Aurea Chersonesus!), "met veertig Regenten onder zijn gebied» (p. 44), die de liefde tracht te winnen van eene Daha'sche (Kð̣̣iri-sche) Prinses, Dewi Angreni (anders gezegd: Raden Galoeh), en plotseling de zucht ook voelt opkomen de "Vorstendommen van Java» te »gaan veroveren» (p. 46); enz. enz.; hij komt, hij vecht, hij valt; de Held van Kẹdiri, Pangeran Kělånå Djajeng Sari, anders gezegd Raden Pandji Koedå Wanengpati, Prins van Djenggålå, in dienst bij den Vorst van Kẹdiri, doodt hem immers in een ijselijk tweegevecht, nadat de Overwalsche Vorst met zijne giftige kris, waar

kan ik op de genoemde twee kaarten niet vinden; aangezien echter de Eng. Zeekaart No. 795 (feitelijk van April 1896) de „S. Sendok" foutief alléén doet uitmonden in de S. Kěsang, maar de Eng. Zeekaart No. 1143 (New ed., Oct. 1910), op een detail-opname van den benedenloop der „Muar River" uit 1909, een kleine riviermonding (zonder naam) vertoont juist daar, waar volgens de landkaart bovengenoemd ( $\operatorname{van} 1911$ ) de "S. Sendok" uitstroomt in de Muar, zoo zal het dorp van dien naam, door Dennys vermeld, moeten liggen aan den mond der tĕroesan van dien naam in de S. Kĕsang; d. w. z. een eindje bovenstrooms van kampoeng "Parit Derhaka", waarvan Zeekaart $\mathrm{n}^{\circ} .795$ de ligging scherp aangeeft. Curieus is nog, dat deze Zeekaart den naam n J a la n Adam" geeft voor het voetpad, evenwijdig aan de kustlijn, van beZ.O. Parit Děrhaka naar den N. mond der Muar; dus gewis een antiek pad; het iets Noordelijker vallend pad, ook weer evenwijdig aan de kust, dat bij Parit Děrhaka begint, heet er: Jalan Rambai ("Begroeid pad"). Over het Kota Boeroek ("Vervallen Vesting") aan den Zuidoost-oever bij den mond, zie den hoofdtekst hierachter, sub C, blz. 150-151.

De kampoeng "Batu” (aldus de landkaart van 1911), aan den Z.oever van den mond der Batu-Pahat-rivier, staat niet op de Zeekaart No. 795, maar wordt er toch gemarkeerd door een lichttoren op een heuvel vlak aan zee van 341 Eng. voet hoog - ter vergelijking diene, dat op deze zelfde Zeekaart de hoogte van den lichttoren op St. Paul's Hill, op den heuvel aan zee van de stad Malaka, de Boekit Malaka dus, staat aangegeven als 180 Eng. voet -; welke heuvel zelf een uitlooper is van den G. "Batu Pahat" (verg. het kaartje bij Phillips. 1906, p. 103), dicht bij zee, waarvan de „Gunong Banang" (= Groote Berg), alias „Mount Formosa", er staat aangegeven met 1422 Eng. $\operatorname{voet}(=433 \mathrm{M}$.) als hoogste top. Doch Dennys (1894, p. 16) heeft voluit: „Batu Pahat. $\mathrm{V}$ [illage] and district on S. side of road $[=$ reede] of same name; W. Johore" alsmede: ${ }_{n} R[$ iver $]$ and settlement in Johore. 
"vlammen uit (schoten) als tongetjes van slangen» (p. 62) hem bijna had doen sneven; het slot is, dat tal van "mannen van het eiland Kěntjånå», met vrouwen en kinderen, en 3 Regenten als hun hoofden, krijgsgevangen achterblijven op Java (p. 64).

Als we dan in aanmerking nemen, hoe in de Sadjarah Mělajoe, die tusschen 1612 en 1614 haar definitieve redactie kreeg, niet enkel in Verhaal XIV een vermaleischt Pandji-verhaal reeds voorkomt, waarin de Vorstin van Madjapahit Raden Galoeh (De)wi Koesoema (verheven door Patih Arja Gadjah Mada!), haar dochter voluit hier: Raden Galoeh Tjandra Kirana (geteeld bij D. K. door eenen Prins van Tandjoengpoera) - , die Prins-Gemaal als Batara, een "ratoe» van Daha, en zoowaar Sultan Mansoer Sjah van Malaka (reg. ca. 1458-1477 A. D.), met zijn Laksamana Hang Toewah, de hoofdrollen vervullen - de oudste, kennelijk voor Malaka's Hof pasklaar gemaakte, redactie van een Maleische Pandji-vertelling - ; maar dat er Verhaal XIX zelfs vertelt van een Vorst van Hoedjoeng Tanah, Makassaar van afkomst, die zich daarheen had begeven om te kunnen zeerooven ( $\mathrm{m} \breve{\mathrm{r}} \mathrm{o} \mathrm{m}$ pak), en nu "sěgala negerri di bawah angin ini» wil gaan "mengalahkan» (ed.-Shellabear, 1898, p. 90), en daartoe, met een vloot van 200 schepen, éérst naar Fava gaat, waar hij talrijke gewesten ( $\mathrm{djadja}$ a n) vernielde zonder dat de Javanen tegen hem durfden optrekken, vervolgens in de kustlanden ( $\mathrm{rantau}$ ) van Siam gaat woeden, dan alle havens (těloek rantau) van Malaka vernielt, waarop een onbesliste(!) zeeslag met Malaka (nog wel zoogenaamd onder dien grooten Mansoer Sjah van hierboven) volgt, maar pas zijn hoofd stoot als hij daarna óók Pasei durft aanvallen; dan herkennen we hier van Maleische zijde een in ca. 1610 in Djohor nog levende dubbele heugenis: $1^{\circ}$. hoe Oedjoeng Tanah minstens éénmaal Midden-Java in doodsnood had weten te brengen; $2^{\circ}$. hoe zoogenaamd "Malaka», maar inderdaad Galoeh, in de Pandji-periode met $\mathrm{D}$ a h a te doen had gehad.

Door de recente studie van Poerbatjaraka, "Historische gegevens uit de Smaradahana» (Tijdschr. Bat. Gen. LVIII, 1919, p. 461-489; met Naschrift van Dr. Bosch, p. 490—492) zijn we nu tot de gewichtige wetenschap gekomen, dat Vorst Kāmeçwara ("Amor's Heer») I van Daha - niet "Bāmeçwara» of Parameçwara», zooals Dr. Brandes nog in zijn Oudjav. Oorkonden (1913, p. 151, 159) gelezen had -, van wien oorkonden bekend zijn uit Caka 1038, 1051, en 1052 (niet toch "1062», zooals Dr. Krom pas 
geleden herkend heeft), den historischen ondergrond vormt van de hoofdfiguur in den Pandji-cyclus. Zijn zegelmerk was een tjandrakapāla ("maan-schedel»; een variant van een banaspati), waarvan men een afbeelding kan vinden in het gezegd Naschrift van Dr. Bosch. Zijn opvolger op den Daha'schen troon was de befaamde, nu nog in de herinnering der Javanen voortlevende Vorst Djajabaja, van wien oorkonden bekend zijn uit 1057 en 1058 - niet "1068» zooals Dr. Brandes 1. e. p. 163 gelezen had - en daarna het jaartal 1079 Çaka der Oudjav. bewerking van het Bhāratayuddha. ${ }^{1}$ Deze nu heeft er twee zegelmerken op nagehouden: in 1057 , toen hij èn sprak van een voor hem “hachelijk oogenblik»vrage tegen Langka? ${ }^{2}$ - èn "Sang Mapandji» in zijn titulatuur voerde, een narasingha ("man-leeuw», Wisjnoe's $4^{\mathrm{e}}$ awatāra); maar al in 1058 een garudamukha, naar Erlangga's gewijden voorgang.

Bovendien houdt dat Verhaal XIX in de Sadjarah Mělajoe dan ook een verre heugenis vast aan den zeestrijd, die er natuurlijk in de eerste helft der $15^{\mathrm{e}}$ eeuw gestreden moet zijn tusschen het machtig opbloeiende Moh. Malaka, het reeds een anderhalve eeuw toen gebloeid hebbende Moh. Pasei-Samoedra, en het veel oudere niet-Moh. Langkasoeka-Oedjoeng Tanah. Waarbij dit laatste zóó volledig werd vernietigd, verlaten en vergeten, dat bij de komst der Portugeezen te Malaka in 1509 en definitief in 1511, dezen alléén vernemen van den ouden roem van het toen nog als dorp voortbestaande Singapoera, doch niets, absoluut niets weten van een Langka of Langkasoeka hetwelk in de Djohor-fjord weleer bestaan zou hebben. In die mate, dat, toen in hun eigen tijd van wassende hegemonie een stad en staat "Jor " = Djohor op het kaapland "Ujantana»= Oedjoeng Tanah in ca. 1530 gesticht werd, niet één van hun talrijke en meestal voortreffelijke koloniale geschiedschrijvers (Barros, Castanheda, Albuquerque Jr., Correa, Couto, Bocarro) het flauwste woord zegt van een vroeger Langka aan diezelfde Djohor-rivier, waar de Portugeezen op 15 Aug. 1587 de hoofdstad "Jor» totaal vernielden, en zoo oorzaak werden van de stichting der nieuwe hoofdstad Batoe Sawar hoogerop, aan den middenloop der rivier (zie nader ons $I I^{\mathrm{e}}$ Gedeelte).

1 Over 1058 Çaka (niet 1068) in de inscriptie-Goerit, zie Brandes-zelf reods in Notulen Bat. Gen. 1893, p. 72-73, en nader Krom in Tijdschr. Bat. Gen. LVI (1914), p. 243. Voor de correctie 1052 Çaka (niet 1062) in de inscriptiePloembangan, zie Krom onlangs in T. B. G. LIX (1921), p. 419-424.

" In deze inscriptie-Ngantang wordt zelfs een "Samgět Langka" vermeld (Oudj. Oork, 1913, p. 158, r. 26-27; met pers, correctic door Dr. Krom). 
Maar bij de eigen Maleiers der $17^{\mathrm{e}}$ eeuw was, blijkens de variant-teksten dierzelfde Sadjarah Melajoe, de herinnering aan het verband tusschen Ganggājoe (= Woerawari), Galoeh (Ptolemaeus' Aurea Chersonesus = «Edelsteen»-land) en Langka, niet totaal uitgewischt. Dat leeren we inzien, wanneer we de hiervóór op blz. $44-45$ behandelde zoo hoogst interessante plaats omtrent "Ganggājoe» in Verhaal I beschouwen in haar 2 groote variant-lezingen: die van LEyden (1821) en Dulaurier (1856) eenerzijds, die van den Moensji Abdoellah bin AbDoELKADIR (ca. 1840) ${ }^{1}$ anderzijds. De 2 Mal. handschriften waarnaar

1 Het jaartal van dezen allereersten Singapore druk met Arab. karakters is tot nog toe slechts bij benadering bekend. Shellabear kwam in zijn belangrijke Preface tot de nieuwe tekstuitgaaf der Sadj. Měl., vermeerderd voor den eersten keer met het Appendix van 4 vervolg. Verhalen (Singapore, American Mission Press, $1896 ; 8+375$ pp.), tot deze conclusie: „Judging from the type from which this Singapore edition was printed, and from the quality of the printing, I am inclined to fix the date of its publication several years sub. sequent to the 1831 edition of the New Testament, which was also printed at the Mission Press, Singapore" (p. 4); welk "also" echter niet geheel gerechtraardigd wordt door hetgeen hij te voren over Abdoellah's „Malay text" had gezegd als "generally believed [sic] to have been printed in Singapore, probably [sic] at the Mission Press" (p. 3). Nu is er reeds dadelijk een heel ander argument, dat de geboorte dezer editio princeps verschuift tot na 1837; en wel dit: Nkwbold, wiens "Political and Statistical Account of the British Settlements in the Straits of Malacca" te Londen in 2 dln. verscheen in 1839, maar waarvan het hs. werd geschreven in 1837 - zooals op meer dan een plaats blijkt, zie o. a. I, p. 17, 47, 79, 391, enz. - weet nog niets van een gedrukten tekst, kent alléén Leyden's "spirited and characteristic translation" (II, p. 334), haalt dààruit aan, zooals soms uịt de in een noot genoemde paginatuur nader nog blijkt (zie I, p. 276), en is, ondanks dat hij een goed Malaicus was geworden gedurende zijn 3-jarig verblijf (1833-35?) in de Straits, zóózeer Leyden's vertaling alleen gebruikend, dat hij - afgaande op diens deels verkorte, deels zelfs foutieve, vertaling van de Inleiding der S. M. - het auteurschap er van toeschrijft aan: "Bandahara Tan Mambang of Malacca" (II, p. 333)! Daạrentegen is het eerste besliste getuigenis dat de Singaporedruk wel bestond, uit Mei of Juni 1846, en van Dulaurier. Naar aanleiding van het eerste gedeelte eener "Etude sur le roman malay de Sri Rama" door A. Dozon in de Mei-aflevering 1846 van het Journal Asiatique (4 Serie, VII, 1846 , p. 425-471), werd toch in de Juni-aflevering onder het hoofd „Critique Littéraire" een schrijven afgedrukt van Dulaurier "A Monsieur le Rédacteur du Journal Asiatique" (l. c. p. 578-586), waarin hij o. a. opmerkte:

${ }_{n}$ De toutes les chroniques malayes, M. Aug. Dozon ne connait que le Schedjaret-Malayou, encore même n'est-ce que par l'intermédiaire de la traduction inachevée et informe de Leyden, qui fut publiée dans cet état, après sa mort, par Raffles. Or, dans cette version se trouvent supprimées, entre autres choses curieuses et intéressantes, les généalogies, c'est-à-dire l'élément ohronologique. Pour juger du mérite du Schedjaret-Malayou, il faudrait done 
Leyden indertijd (tusschen 1805 en zijn dood in 1811) zijne gecombineerde vertaling maakte, werden weliswaar nog niet precies aangewezen, maar schuilen hoogstwaarschijnlijk onder de 4 hss. van dat geschiedwerk uit de collectie-Raffles in de Bibliotheek der Royal Asiatic Society te Londen, $\mathrm{n}^{\text {os }} 35,39,68$, en 76 , nader beschreven in het «Kort Verslag» van V. d. Tuuk - die schitterende, tintelende studie! - in Bijdragen Kon. Inst. 3, I, 1866, ${ }^{1}$

avoir lu le texte original, dont il existe une edition qui a vu le jour a Singapore et qui, quoique rare en Europe, n'est pas cependant introuvable." (p. 580; de spatieering is van mijzelf). Hieruit blijkt tevens, dat Dulaurier die uitgaaf toen zelve bezat, terwijl hij in zijn "Mémoire etc." van 1843 zelfs nergens blijk geeft vernomen te hebben dat zij bestond. Aangezien nu de Abt Favre, een van zijn leerlingen in 't Maleisch en later zijn ambtaopvolger geworden, in 1845 als missionaris naar 't Schiereiland Malaka was vertrokken, mag men concludeeren: $1^{\circ}$. Dulaurier had zijn Singapore-exemplaar in 1845 of begin 1846 gekregen door bemiddeling van Favre; $2^{\circ}$. de uitgaaf valt tusschen 1837 en 1845, zeg dus: ca. 1840.

Niet genoeg kan hierbij gewaarschuwd worden tegen de zéér foutieve aanteekening van niemand minder dan Dr. R. Rost, bij de heruitgaaf in 1887 van V. d. Tuuk's Short Account (zie volgende noot), waar hij op p. 17 bij de Sjadjarah Mĕlajoe (V. d. Tuuk's n. 18 der Raffles-hss.) aanteekende: „The work was lithographed by Keasberry at Singapore in $1830^{\prime \prime}$. Want $1^{\circ}$. is het géén lithographie, maar boekdruk ; $2^{\circ}$. kwam de zendeling-lithograaf-boekdrukkerMalaicus Benjamin Peach Keasberry, geboren 1811, pas in 1837 te Singapore, en stierf er in 1875 (zie Buckley's „A Anecdotal history of old times in Singapore", 1902, I, p. 320-322). Daar nu Keasberry in 1839 overging van zijn aanvankelijk verband bij een Amerikaansch Zendeling-genootschap dat vooral in China werkte, naar „the London Missionary Society, and learned Malay from Munshi Abdulla" (Buckley, p. 321), ziet men hoe sterk tout deze aanteekening is van Dr. Rost; die b.v. overgenomen werd wat het jaartal „1830" betreft in Dr. Juynboll's Catalogus (1899), p. 230.

De Voorrede van den Singapore-druk, die als titel de schijnbare mystificatie draagt: „Bahwa ini pĕrkataän sĕgala Toewan² dalam nĕgĕri Singapoera jang hĕndak mĕmasjhoerkan bahasa Mělajoe" (ex. Kon. Inst.), moet dan ook opgevat worden als: ,woorden van Moknsjr AbdoelLah (die immers óók Toewan was krachtens zijn kwart-Arabische afkomst) cum suis"; onder welke laatsten in ca. 1840 speciaal moeten gerekend worden de in 1843 pas afgetreden Gouverneur Bonнaм (vriend en fautor van Abdoellah), de verdienstelijke J. H. Moor (Directeur van Raffles Institution; overleden Mei 1843, zie Buckley, ib. p. 133), en B. P. Keasberry bovengenoemd (toen "Superintendent of the Malay classes" aan dat Instituut, ib.). Met den druk - gewis ter Mission Press, op Baffles' Square; verg. Buckley p. 322 - heeft zeker KEAsberRY zeer veel bemoeienis gehad; dit is dus het éénige wat juist is in Dr. Rost's bericht. Deze zelfde Keasberry had later ook een regulieren handel in Maleische hss.; zie b.v. de lijst uit 1866 bij V. d. Tuuk in Bijdr. Kon. Inst. 3, I, p. 471-474.

1 Het is een eenigszins ingewikkelde geschiedenis met deze studie. De eerste druk verscheen in 't Engelsch als "Short account of the Malay manuscripts belonging to the Royal Asiatic Society", in Journ. R. As. Soc., New 
p. $425-426$, onder $n^{\circ}$. 18. Van den standaardtekst van Abdoellah, en de " 2 of 3 andere» welke hij, blijkens de Voorrede "Perkataän sěgala Toewan ${ }^{2}$ dalam něgěri Singapoera jang etc.», bij zijn baanbrekende tekst-uitgaaf gebruikt heeft, is tot heden niet bekend waar zij thans mogen schuilen. Zelfs de standaardtekst van Dulaurier, "notre texte" zooals hij dezen in zijne Noten noemt, is (indien ik mij niet bedrieg) tot heden niet pertinent aangewezen in de een of andere openbare bibliotheek; vermoedelijk is het echter ook één der Raffles-hss.; slechts zijn "Ms. A», waaraan hij in de Noten zoo aanzienlijke varianten ontleende, is "ons [Leidsche hs.] $n^{n}$. 1716», zooals we door Pijnappel in Bijdragen Kon. Inst. 3, V (1870), p. 163 weten; Dulaurier, die zijn uitgaaf van 1856 midden in de helft van zijn tekst staakte, en pas op $21 \mathrm{Dec}$. 1881 stierf, heeft niet zoozeer geen "loisir» als wel geen "plaisir» gehad om de nevelen nopens zijn materiaal weg te nemen! ${ }^{1}$

Series, II (1866), p. 85-135; aan het eind staat: „Amsterdam, November 25, 1865”, terwijl aan het begin staat: „[Presented July 3, 1865]”; ook behoort er nog een los blad "Corrections to Art. IV" bij, dat dus blijkbaar ten tijde der correctie door V. d. Tuuk in Nov. 1865 werd toegevoegd. De tweede vermeerderde druk verscheen in 't Hollandsch als „Kort verslag der Maleische handschriften, toebehoorende aan de Royal Asiatic Society te Londen", in Bijdragen Kon. Inst., 3 e Reeks, I (1866), p. 409-474; aan het eind staat: "Amsterdam, 27 Junij 1866", maar nergens wordt er gerept van den beknopten Eng. druk. De derde bijgewerkte druk is een herdruk door Dr. R. Rost naar den $1^{\text {on }}$ Eng., aangevuld uit den $2^{\text {en }}$ Hollandschen - zeer ten onrechte betiteld als ,the Dutch translation" - en bijgewerkt nog uit andere Holl. bronnen tot en met 1882 (nl. De Hollander's Handleiding, $5^{\circ}$ druk); deze $3^{\text {e druk }}$ verscheen in de "Miscellaneous Papers relating to Indo-China and the Indian Archipelago", Second Series (1887), II, p. 1-56. Verschillende belangrijke dingen werden echter in dezen $3^{\text {on }}$ druk weggelaten, welke men alléén vindt in den Holl. tekst van 1866; deze laatste blijft dus de standaard-tekst, waarnaast men den Engelschen van 1887 als aanvulling moet leggen.

Precies hetzelfde is het geval met Groeneveldt's "Notes on the Malay Archipelago and Malacca" van 1876 - of in het volle Dl. 39 der Verhandelingen Batav. Gen., met jaartal: 1880 -, en den nog wel door Groeneveldtzelven bewerkten, maar in den aanvang gekortwiekten - immers van de geheele "Introduction", met haar "List of the works which have been consulted in making this compilation" (p. III-X) ontdanen $-2^{\text {en }}$ druk in dezelfde Second Series der Miscellaneous Essays, dl. I. Ook hier dus moet men de Holl. uitgave als de standaard-uitgave blijven beschouwen, met de 2 e er naast.

1 Hetgeen Shellabear in zijn, overigens zoo hoogst interessante, Preface tot zijn tekstuitgaaf met Arab. letters van 1896 zegt, dat de poging. van DULadrier "to publish a revised text unfortunately failed, owing to the death of the editor”, en nogmaals: „but M. Dulaurier did not live long enough to complete it" (p. 4), is dus heelegaar er naast. Ook spreekt Shellabear van deze uitgaaf als "from the Imprimerie Nationale, Paris, in 1849" (ib.); lees: 
Laat ons nu die 2 groote variant-lezingen bezien, welke ons hier interesseeren; gemakshalve resp. naar de vertaling van DEvIC uit 1878, die naar DULAURIER's tekst vertaalde, en naar de vertaling van MARRE uit 1900, welke den Singapore-tekst van ABDOELLAH tot zijn legger nam. ${ }^{1}$

LEYDEN, die min of meer summier vertaalde, had gegeven:

1856; Dulaurier's uitgaaf van 1849 had als "Premier Fascicule” den tekst gegeven der Hikajat Radja-Radja Pasai, waarop in 1856 de "SchedjaretMalayou" als "Second Fascicule" volgde, maar zonder eenige inleiding of opheldering, welke dus bewaard werd voor het slot.... dat nimmer kwam.

Zijn tekst eindigt liefst midden in een zin achteraan Verhaal XV (achter het woord .,děngan"; in Shellabear's editie van 1898: p. 78, regel 10); hetwelk echter bij Dulaurier gelijk staat met een Verhaal $n^{\circ}$. 13, aangezien bij hem $\mathrm{X}$ en XI samensmolten met IX. Dat Shellabear's vermoeden omtrent Dulaurier's "notre texte, (probably the Singapore edition, with which it is almost identical)" (ib.) geenszins juist is, blijkt alleen reeds uit het straks in den hoofdtekst aan te halen proefje omtrent Ganggājoe-Langkājoe in Verhaal I; ook Pijnappel (Bijdr. K. I., 1870, p. 163) had dit reeds, zelfs pertinenter, beweerd; nog erger fout was Klinkert geweest in Notulen Bat. Gen. 1866, p. 177-178. - Maar het meest krasse bij deze onvoltooide uitgaaf van Dulaurier dunkt mij, dat de abbé FAVRe, die in 1862 de opvolger werd van Dulaurier voor Maleisch en Javaansch aan de École des langues orientales vivantes te Parijs, den plicht niet heeft gevoeld om den arbeid af te maken van zijn voorganger, welke toen hoogleeraar was in 't Armenisch. Favre stierf pas in 1887, vijf jaar na Dulaurier, en had dezen dus jaren lang voor alle inlichtingen vlak naast zich!

In Lexden's vertaling loopt het ééne door dezen gebruikte hs. tot even voorbij den dood van Hang Kastoeri in Verhaal XVI (Leyden's slotwoord „palace”, op p. 193 regel $12=$, ,berglar" in den Shellabear-tekst, 1898, p. 83 regel 8), en evenver, blijkens V. d. Tuuk, loopen de 3 Raffles-hss. n ${ }^{\text {os }} 35$, 39 (door een drukfout op p. 426: „89”), en 68; het tweede hs. waarnaar Leyden toen verder vertaalde (bij hem p. 193-361) geeft het slot van dat Verhaal XVI, en daarna - met geheel versprongen nummers I-VIII, en van p. 268 af zonder nummer en deels andere afscheidingen - Verhaal XIX-XXXIV van den textus receptus (ed. Abdoellah-Dulaurier; en óók Shellabear, daargelaten diens Appendix hetwelk Verhaal XXXV-XXXVIII vormt). Derhalve ontbraken in Leyden's $2^{\circ}$ hs. de Verhalen XVII-XVIII, en dit nu klopt weer met het Raffles-hs. $n^{\circ}$. 76, dat enkel Verhaal XIX-XXXIV bevat, blijkens V. d. Tuuk's beschrijving. Het slot van Verhaal XVI bij Leyden (p. 193-199) schijnt dus bij hem aan een $3^{\circ} \mathrm{hs}$. toch te zijn ontleend. Eén enkel nader onderzoek door een Malaicus te Londen zou hier zekerheid kunnen geven omtrent Leyden's bronnen.

Overigens weet men, dat, blijkens Raffles' Introduction voor deze uitgaaf van 1821, wegens Leyden's onverwachten dood ( $\dagger$ te Batavia, 28 Aug. 1811), ontbreken de door dezen beraamde "notes and references, explanatory of the more interesting parts" (p. VI). Om nu maar niet te spreken van 't plan van Leyden, om óók te geven: "the late Annals of the different states of the Archipelago, since the establishment of Mahometanism" (p. VI-VII). Dààr zijn we thans zelfs nog niet aan toe!

1 Devic heeft in zijn vertaling („Légendes et traditions historiques de 


\section{WAS MALAKa EMPORIUM VóóR 1400 A. D., GEN. MALAJOER?}

"From Gangga Nagara [bij Dinding; verg. hiervóór blz. 42], Raja Suran advanced to the country of Glang Kiu, which in former times was a great country, possessing a fort of black stone up the river Johor. In the Siamese language, this word signifies the place of the emerald (Khlang Khiaw) but by persons ignorant of this language, it is usually termed Glang Kiu.» (p. 10).

DEviC: "Quelque temps après [d. i. na «Gangga-Nagara»], il [= "le roi Souran»] parvint à la ville dẹ Ganggayou. C' était autrefois une grande ville, dont le fort de pierres noires existe encore aujourd'hui. Ce fort est à l'extrémité de la rivière Djohor. Le nom de Ganggayou en langue siamoise signifie "trésor d'émeraudes», et l'expression siamoise que nous n'avons pas su prononcer s'est transformée en Ganggayou.» (p. 15-16).

MARRE: "Après la soumission du pays de Gangga-Nagârâ, Râdja Sourân partit; après quelque temps de marche, il arriva à la ville de Ganggâyou. Cette ville autrefois était considérable, son fort construit en pierres noires existe encore aujourd'hui à la source de la rivière de Djohôre. Son nom était primitivement Lankâyou qui, en langue siamoise, signifie "trésor de pierres précieuses», mais nous n'avons pas su le bien prononcer, et nous avons dit: Ganggâyou.» (p. 10-11).

Leyden's vertaling, welke 2 maal "Glang Kiu» heeft en géén "Ganggayu», is niet te toetsen aan haar origineel; als kenner van Indochineesche talen voegde hij den zuiver-Siameeschen

l' Archipel indien (Sedjarat Malayou) traduit pour la première fois du malais en français, et accompagné de notes"), alléén gegeven eene „Première Partie”, n.l. Verhaal I-XI (behalve de slot-alinea), vertaald naar Dulaurier's tekst, onder weglating van de moeilijke Inleiding; zijn belofte in de Préface: „Je renvoie à un volume subséquent ce qu' il peut $\mathrm{y}$ avoir à dire sur le livre même" (p. VI), bleef... belofte. De nummering IX bij Devic voor zijn slothoofdstuk, in plaats van XI, is een gevolg der hoofdstuk-indeeling bij Dulaurier, die, zooals boven werd gezegd, Verhaal X en XI samensmolt met IX.

MARre vertaalde naar Abdoellah's Singapore-tekst (zie bij hem p. 271), dus Verhaal I-XXXIV, alleen met weglating van Abdoellah's Voorrede, en (alweer) de moeilijke Inleiding van den auteur, Toen Moehamad; zijn „sans suppression" (p. 271), is dus niet geheel en al waar; zijn Index achteraan, hoe onvolkomen ook van opzet, is een kostelijke toegift. Dit boek van 1900 is doorgepagineerde overdruk uit Le Muséon, 1e Sér. XV (1896)-2 Sér. I (1900); de binnentitel, met jaartal 1896, wijkt af van den omslag-titel met jaartal 1900. 
vorm "Khlang Khiaw» echter verhelderend toe; maar de aannemelijkheid der Maleische redeneering in dezen vorm is gering, om niet te zeggen nul. In Dulaurier's tekst, door Devic vertaald, komt tot 3 maal toe de plaatsnaam "Ganggājoe» voor (1 ${ }^{\circ}$. něgerri Ganggājoe, p. $19 ; 2^{\circ}$. aṣal namanja Ganggājoe děngan bahasa Siam artinja perbendaharaän perrmata, p. 19-20, waarbij Dulaurier - conform Leyden - in een noot 1 aanteekent: „En siamois khlang khiaw, "le lieu de l'émeraude»"(p. 20); $3^{\circ}$. djadi Ganggājoe, (p. 20); maar géén "Glang Kiu » of "Klang Kiu», dat weggelaten is blijkbaar uit het logisch zinsverband, zooals Shellabear's tekst dit toont (Arab. schrift, 1896, p. 16, regel 12-15; transcriptie, 1898 , p. 8). ${ }^{1}$ Maar in de Singapore-uitgaaf van Abdoellah, de editio princeps der Sadjarah Melajoe (ex. Kon. Inst.) staat op p. 18, regel 3-7, zoowaar eerst: "něgeri Gang gājo e»(als Dulaurier); dan "așal namanja Langkājoe [óók te lezen: Langgājoe] ijaitoe bahasa Siam artinja perběndaharaän pěrmata»; en ten slotte weer: «djadi Ganggājoe»(als Dulaurier).

Hier ziet men dus: in deze 2 Maleische standaard-teksten van Abdoellah en Dulaurier wordt op een allercurieuste wijze gespeeld met de vormen Ganggājoe (Gangga + ajoe) en Langkājoe (var. Langgājoe), alsmede met een begrip van een plek van edelsteenen (pĕrmata), kortom van Juweelen (Arab.-Mal. Djauhar). D. i. toch wel: Djohor=Ratna=Galoeh? Zie nader blz. 133!

Maar er is nog een héél andere kant aan het Garoeḍa-vraagstuk; op Java-zelf, uit de $16^{\mathrm{e}}$ eeuw. Hoezeer de Javanen uit dien

1 Shellabear's tekst is: „Satělah nĕgĕri Gangga-Nagara soedah alah, maka Radja Soeran poen běrdjalanlah dari sana. Satělah běrapa lamanja di djalan, datanglah kapada nĕgěri Ganggajoe. Sjahadan dĕhoeloe kalanja nĕgĕri itoe nĕgěri běsar, kotanja daripada batoe hitam, datang sěkarang lagi ada kotanja itoe di hoeloe soengai Djohor. Adapoen asal namanja Klang Kio, ija-itoe bahasa Siam, artinja pěrběndaharaän pěrmata; oleh kita tijada tahoe měnjĕboet dija, djadi Ganggajoe. Adapoen nama radjanja Radja Tjoelan; etc."

In deze beide edities heeft Shellabear voor het allereerst dat gewichtige A ppendix gepubliceerd (ed. 1896, p. 327-375; ed. 1898, p. 165-190), welke de slot-Verhalen XXXV-XXXVIII van den volledigen tekst bevatten, met dien gewichtigen kolophon aan 't eind welke in ons $I I^{\circ}$ Gedeelte, sub VIII, bij de behandeling onder $i$ van de plaats Batoe Sawar, ten volle zal opgehelderd worden. Die 4 Appendix-verhalen beginnen in Shellabear's transcriptieuitgave van 1898 op resp.: p. 165 , regel 1 ; p. 166 , r. 26 ; p. 171, r. 15 ; en p. 173, r. 4. In den tweeden druk der transeriptie-uitgaaf (1910, 2 deeltjes) heeft Shellabear helaas op verwarrende wijze dit Appendix van 4 Verhalen laten dóorloopen als gewaand slot van Verhaal 34. Van gezegd Appendix gaf Dr. van Ronkel een verkorte vertaling in Tijdschr. Bat. Gen. 44 (1901), p. 358-372. 
tijd van godsdienstovergang volkomen wisten, dat de Garoeḍa het symbool was van een overwinnend Hindoeïsme op een buitenlandsche Naga, blijkt uit het feit dat de aanhangers van den, uit het buitenland alweder gekomen, Islām hùn triomf over het Javaansche Hindoeïsme weer bij voorkeur symboliseerden in de gedaante van de $\mathrm{Naga}$; die b.v. aan de monumentale trap van de měsigit te Giri bij Grěsik, gelijk een kolossale Ardawalika, weerzijds naar beneden kronkelt als dubbele hoeder der trapleuningen beneden de gapoerå-poort halfweegs; die op de deuren der moskeeën van Dëmak en Toeban een groote rol speelt; ${ }^{1}$ die het geliefde ornament werd voor Vorstelijke gong-standers op Java; die misschien ook de na 1708 verdwenen makoeța (zie hiervóór blz. 110, met noot 1) fixeert als een "Kroon van Dĕmak», kwansuis in Nov. 1677 genoemd: "de oude koninklyke Madjapaitse sierlyke gouden kroon» (De Jonge, VII, p. 246). Duidelijk gezegd: de vreemde Naga uit het land Atas-Angin (West-Voorindië c. a.), wierp den inheemsch-geworden Garoeḍa van BawahAngin (Indonesië c. a.) er weer uit; de Garoeḍa redde alleen in hoofdzaak zijn vleugels, ... als lar's (lar rangkěp of lar lå mbå, dus "dubbel» of "enkel») op de stille velden der Batik-patronen.

Is het dan daarnààst niet opmerkelijk ook, dat de Garoeḍavogel zoo'n overmachtig symbool is gebleven op het eiland Bali; dat, nu nog Hindoeïstisch, in Erlangga's tijd het eerst onder de blijvende macht kwam van Oost-Java? Want wat V. D. TuUk, die niet het minste oog voor kunst had, over »arddhawalika» zegt in zijn ontzagwekkend Woordenboek, is ten deele precies fout; de Balineesche "ardaüalika» wordt niet ook "afgebeeld op de pala ${ }^{2}$ [zijkanten] van een paduraksa [staatsie-poort] met kippepooten en wieken» (I, 1897, p. 107a), want dit geheel stelt voor een Garoeḍa, en niets anders; hij had het moeten opnemen bij zijn interessant stukje over Garuḍa (IV, 1912, p. 672).

Want op Bali is thans nog de Garoeḍa een zóó veelgeliefd symbool, dat het in het midden der padoeraksa-poorten, boven den doorgang, pleegt voor te komen op analoge wijze als de Leeuwenkop (of banaspati) boven ingangen tot Oudjav. tempels: angstaanjagend, en daardoor voorbehoedend. Sluit dit verschijnsel ook

1 Voor de Naga's te Giri, zie reeds - hoewel juist met de averechtsche opmerking, dat dit "met het Mahomedanisme niets gemeen heeft" - Brumund, Bijdr. kennis Hindoeïsme (Verh. Bat. Gen. XXXIII, 1868), p. 184. Voor Dĕmak's mĕsigit-deuren, zie Notulen Bat. Gen. 1893, p. 66-67, en 1894, p. 116. 
weer niet prachtig aan bij den eigen naam van het eiland "Bali», d. w. z. bij den naam van den «titan» (daitya) die werd overmeesterd door Wisjnoe, in het Rāmāyana (zie V. d. Tuuk, IV, p. 973)? Dat is dus: als een eiland onderworpen door een WisjnoeVorst, in diens $\bar{j}^{\mathrm{e}}$ awatāra als Dwerg? ${ }^{1}$

Zóó komen dan de naam, de oudere historie, en de nog levende ornamentiek van Bali in verrassend verband. De kans is ook geenszins uitgesloten, dat uit de talrijke nog ongelezen plaatsen in Erlangga's Sanskrit- en Oudjav. inscriptie te Calcutta te eeniger tijd óók de naam "Bali» te voorschijn zal treden.

7. De Memreng of het Buffelkalf, Karbouwen-jong, de Djedjawen saṇțeng of "bull» van Raffles uit 1817, de "buffel zonder hoorn, van den ouden C. F. Winter uit 1843, is een waarachtige politiek-historische verrassing. De quintessence der Pamalajoe van 1275-'93 A. D., de onderwerping van Menang$\mathrm{ka}(\mathrm{r}) \mathrm{bau}$ door Java onder Toemapel's Vorst Kerrtanagara, gesymboliseerd in een Rijkssieraad van het Solo'sche Hof, — daar wist

1 Deze verschijning van Wisjnoe als dwerg (wämana) is voorkomend als beeld te Prambanan; verg. Veth's Java, 2en druk, I (1896), p. 80-81, en 160; de betrekkelijk-groote eerbied daarbij van "Wisjnoe" voor "Bali" is in 't verband niet over het hoofd te zien. De op één na oudste bekende inscriptie op Bali is die van 844 Çaka, in Oudjav. schrift maar Balin. taal, to Sěmbiran (OostBoeleleng), dus even vóor het optreden van Mpoe Sindok als Vorst over zoowel Midden- als Oost-Java. Zie het hoogst belangrijke opstel van Dr. Brandes in Tijdschr. Bat. Gen. XXXIII (1890), p. 16-56: De koperen platen van Sĕmbiran; en ten deze vooral p. 27 en 28 , waar Brandes er eenerzijds aan herinnert: „dat juist in de opschriften van Mpu Siṇḍok reeds herhaaldelijk een Balị̂̂wara voorkomt, dat men onwillekeurig vertaalt met „Heer van Bali", en dat alsdan er op zou wijzen dat Bali reeds vroeger in contact met Java zou zijn geweest in een verhouding als van een vasalstaat"; maar anderzijds: "dat de Balineezen de belangrijkste oud-Javaansche literatuurproducten beschouwen als gewrochten uit den tijd van Erlangga, wat tot op een zekere hoogte geen tegenspraak duldt, en hunne herinneringen omtrent Java eigenlijk gezegd toch niet verder teruggaan." - Een iets ouder oorkonde, van 832 Çaka, vermeldt thans vax Stein Callenfels in Oudhcidk. Versl. 1920, p. 41.

Conclusie: reeds in Vorst Daksha's tijd (ca. 820-840 Çaka), tijdens de stichting van Prambanan, was Bali afhankelijk geworden min of meer van Java; Vorst Mpoe Siṇdok (ca. 850-870 C..) bevestigde deze hegemonie; doch pas onder Erlangga (941-ca. 964 (̧.) kwam Bali ten volle onder Oost-Java's heerschappij. Zéér onlangs is daarbij nog het verrassende jaartal 998 Çaka gevonden, als dat der "overwinning van Djanggala", geboekstaafd in een korte Oudjav. inscriptie, aangetroffen op den top van den G.Panoelisan(Noord-Bangli) door. W. O. J. Nieuwenkamp; zie toch Tijdschr. Aardr. Gen. 2, XXXVI (1919), p. 623, met Ned.-Indië Oud \& Nieuw, V (1920-21), p. 115, 117; en Prof. Krom's oratie "De Sumatraansche periode der Jav. geschiedenis" (1919), p. 20 noot. 
tot heden niemand van! Men ziet hier tevens afdoende aan het licht treden, hoe de Maleiers hun historie-verhalen van deze authentieke gebeurtenis in hun voordeel hebben... verdraaid, om niet te zeggen verzonnen, of vervalscht. Want dat Buffelkalf, dat, volgens de jongere Maleische lezingen (men zie de uiteenzetting van BRANDES in zijn Pararaton, 1896, p. $129^{1}$ naar de Hikajat Radja ${ }^{2}$ Pasai), als kampioen van Menang-karbau den kolossalen karbouw van den Vorst van Madjapahit overwonnen zou hebben, is inderdaad... als teeken van overwonnen-worden nog thans terug te vinden onder de 8 regalia van het Solo'sche Hof! Het land Malajoe dus is, als overwonneling, in den vorm van een jong Mal. rund (djawi-djawi) van goud (Raffles' "jajáwen») in 1293 A. D. medegebracht naar het Toemapelsche Hof; ${ }^{2}$ en sindsdien door de Javanen wel allereerst, door de Maleiers later pas, aangeduid als Měnang-kĕrbau. ${ }^{3}$ Versta: ònze groote Jav. Karbouw hééft het gewonnen (op dat Mal. buffelkalf); GrootJava heeft Klein-Java (Java Minor, Mūla Djāwa, enz.) verslagen.

8. De Senoek of Tapir van goud, alléén door den translateur C. F. Winter Sr. in 1843 vermeld, en een "Rinoceros» geheeten, is, naar de mooie opmerking van V. D. TuUk reeds in 1872 (Not. Bat. Gen. X, p. 150), "een tapir, en dus een herinnering aan een vroegere overheersching van Sumatra door de Javanen; Lamp. en Mal. těnoek»; of ook in het Mal.: koeda arau, k. ajer, k. rimbau. Dat dit rijkssieraad een overwinning op Zuid- of anders Midden-Sumatra moet symboliseeren, ligt reeds voor de hand omdat dààr voornamelijk de tapir huist; dat dit dan meest waarschijnlijk weer Palembang zou dienen te zijn, is vanzelfsprekend, omdat deze staat van oudsher de groote concurrent van Java is geweest in den Indischen Archipel (verg. hiervóór blz. 92-93, en vooral sub $\mathbf{C}$ hierna). Maar dit sterke vermoeden wordt haast tot volle zekerheid, nu we bij V. d. Tuuk in zijn Kawi-Wdb. (III, 1901, p. 23a) i. v. sĕnuk nog vinden: «in een tjandra

1 Thans in $2^{\circ}$ ed. Brandes-Krom (1920), p. 151-l52.

2 Vrage: kan de naam $\mathrm{Dj}$ a djaw $\mathrm{a}=\mathrm{Tj}$. $\mathrm{Dj}$ a w i nu, van Vorst Kĕrtanagara's graftempel, ók hiermede in verband staan? Zie over dezen tempel thans Dr. Krom's Inleiding tot de Hindoe-Jav. kunst, 1920, II, p. 71-81.

${ }^{3}$ Het oudste voorkomen van dezen naam is in $1511-12$ in de oudste Port. berichten, tijdens de verovering der stad Malaka door Albuquerque; dat het toen nog "Hindoesch" was, blijkt uit de Commentarios van Albuquerque Jr. (1॰ druk, Lissabon 1557), Parte III, cap. 37, zie de Bijlage sub 1 achter ons IIe Gedeelte. - Dit tevens in antwoord op een vraag van FerRand, II, p. 75-76. 
s ěngka la wordt melding gemaakt van een sěnuk uit Pa èmbang aan den vorst van Mataram [sic] aangeboden». Waar die tjandra sengkala te vinden is, geeft $\mathrm{V}$. d. Tuuk niet aan (soms in het Dharmawitjara, 1. c. ook vermeld?). Iets naders over dat tijdstip te zeggen, zou dus nauwelijks mogelijk zijn, als we niet de Chin. Annalen der Ming-dynastie hadden, die de misschien eenigszins geflatteerde mededeeling der Nāgarakrětāgama (Zang 13:1) dat "Palembang" $\mathrm{n}^{n}$. 2 der onderhoorigheden was van Madjapahit op Sumatra - dus reeds in of vóór 1365 A. D. - , op merkwaardige wijze aanvullen door te constateeren dat Sanbo-tsai in $\mathbf{1 3 7 7}$ of $\mathbf{1 3 7 8}$ "had already been conquered by Java», en dat: "After this occurrence San-bo-tsai became gradually" poorer and no tribute was brought from this country [to China] any more» (Groeneveldt, Notes, 1876, p. 69, en verg. p. 36 ; of $2^{\circ}$ ed. 1887 , p. $193-194$, en verg. p. 161-162).

Voor een Tapir als Javaansch rijksornament mogen we dus op z'n vroegst ca. 1360 aannemen, terwijl het nog duistere gegeven bij V. d. Tuuk veeleer wijst naar lateren tijd, b.v. toen Java in de $15^{\mathrm{e}}$ eeuw gewis heer en meester was over Palembang (verg. den jongen, laat-Madjapahitschen, ouderdom der Lermatang'sche beeldwerken; alsmede de historische figuur Arja Damar). De groote vergetelheid waarin dit Rijks-ornament is komen te verkeeren, pleit eveneens voor zijn ontstaan in een periode van Java's politieken teruggang, zoo geheel anders dan toen de Gans, de Garoeḍa, de Naga, waarschijnlijk ook de Haan en de Olifant, en gewis ook het Buffelkalf - om van den onzekeren Kidang te zwijgen als symbolen van Javaansche staatsglorie tot aanzijn kwamen.

Als interessant bewijs van die vergetelheid, waarin niet alleen de Tapir, maar zoowaar óók het Buffelkalf voor het bewustzijn der tegenwoordige Javanen verzonken is, moge dienen de uitleg dien de zendeling P. JANSZ in zijn Jav.-Ned. Woordenboek van 1876 gegeven heeft van de termen saṇțeng - het woord memreng kent hij alleen als adjectief - en sěnoek. Voor het eerste geeft hij: "naar men zegt, een boschdier, als een banțèng, ter grootte van een kat»; voor het tweede: "een onbekend beest, ten spreekwoord voor leelijkheid»! Waarnaast het groote Jav. Wdb. van Roorda-Vreede (1901), hetwelk géén s a ṇ țe n $\mathrm{g}$ kent (zie toch I, p. 753b), maar s ě noek goed geeft (ib. p. 743-744), ons i.v. memreng (II, p. 517b) op gezag van Withens N. B. translateur en officieel persoon te Solo! - eerst voorzet: 
"een fabelachtig beest, naar men zegt, een langharig soort van hertebeest , en, nog erger, op gezag van ROORDA (doch met vraagteeken): "een spook, dat de gedaante van een orang-oetan zou hebben", en dan pas de memreng mas uit Solo.

Zóó volstrekt is dus de heugenis aan deze twee oepåtjårå vervaagd, dat zelfs een Solosche prijaji met schijn van recht tegenwoordig zou kunnen beweren: het getal van des Soenan's Rijksornamenten is 6, en niet meer; geheel zooals ... DEELEMAN zich reeds in 1846 heeft laten wijsmaken. Vrage daarom : zijn deze twee, die de volle 8 van Solo nog in C. F. Winter's tijd completeerden, heden ten dage wel aanwezig in die kamer $n^{\circ} .62$ van V. Zimmermann's voortreffelijken plattegrond uit 1915 van den Solo'schen Kẹdaton (Tijdschr. Bat. Gen. LVIII, 1919), in 't midden van den Noordwand der Pråbåjěkså ( $\left.{ }^{\circ} .58\right)$, achter de heilige P ̌tanen (= Padjangan, staatsiebed, Vorstensponde; $n^{\circ} .59$ )?

Immers, in deze kamer zijn "de heiligste stukken opgeborgen in kleine huisjes, die op palen rusten en waarin men langs ladders komt» 1. c. p. 319-320); d. w. z.: in hun eigen Geestenhuisjes. ${ }^{1}$

Van die acht zijn 4 de doorloopend-officieele Solosche Rijksornamenten, samengevat in den gewonen term banjak dalangsawoeng galing; n.l. in deze volgorde van links naar rechts, ziende naar den Soenan (dus van rechts naar links heraldisch):

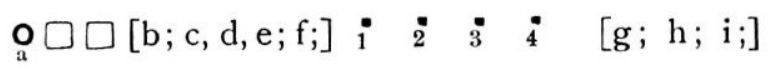

waarin: a. de groote pajoeng van den Soenan, waarnaast 2 prijaji's ( $\square$ ) als bewakers van de 12 aan hun rechterzijde geschaarde 5 a mpilan +4 o e påtjåra +3 a mpilan; en wel aldus :

b. een lopak-lopak (sirih-doos van goud); $c, d, e .3$ těkěn's (wandelstokken); $f$. de katjoe mas (puntige zakdoek-koker); 1. de Kidang; 2. de Banjak dalang; 3. de Sawoeng galing; 4. de Ardåwalikå;

$g$. de koețoek (vierkante tabaks-doos); $h$. eene lampit

1 De buitengewone beteekenis van dezen plattegrond (1:750; met toelichting door den heer Zimmermann, is, dat, dank zij den aanleg van electrisch licht in den binnen-kraton - de Tjĕpoeri; een term, die bij hem ontbreekt de geheimen van dat binnengedeelte voor het eerst ontsloten konden worden. Voor „Pråbåjĕkså” (of Pråbåjåså) heeft $Z$. het nog meer opgesierde: Pråbåsoejåså (p. 319, 332); verg. Roorda-Vreede's Wdb., 1901, II, p. 249b; voor "Pĕtanen" = Padjangan, zie daar II, p. 267b sub patani, en 319a.

Een schets van zoo'n Vorstelijk-Solosch geestenhuisje - hoe heeten deze? soms d̦ẹ̆ĕmitan? - gaf Zimmermann in zijn toelichting op p. 319. 
(zitmat); $i$. de bogěm mas (een vorstelijke bidet, wanneer Z. M. mocht willen urineeren). ${ }^{1}$

Aldus werd door mij genoteerd op Konings-verjaardag (19 Febr.) 1889 in het Residentie-huis te Solo, toen deze pajoeng-drager +2 prijaji's +12 insigniën-dragers - thans allen mannelijke pånåkawan's, geen meisjes! - gehurkt zaten in de voorgalerij van het Residentie-huis, ieder met zijn insignie op zijn schoot, ziende naar binnen (d. i. naar het Westen); terwijl de Soenan, met den Resident aan zijn linkerhand, daarbinnen in de troonzaal zaten, ziende naar buiten (d. i. naar het Oosten). Helaas maakte ik geen aanteekeningen over het aantal en de volgorde der oepatjårå bij den Garěběg Běsar (7 Aug. d. a. v.); ik vermoedde toen nog allerminst het historisch gewicht van dit onderwerp; wèl teekende ik aan, dat in vergelijking met het - ook in verscheiden andere gevallen! - zooveel strenger en antieker bewaarde ceremonieel aan het Jogjasche Hof (waar ik den Garěbęg Moeloed op 16 Nov. 1888 nauwkeurig had bestudeerd), een groot verschil bestond bij de volgorde der oepatjara-groep in den stoet te Jogja en Solo: te Jogja gaat de stoet van den Assistent-Resident + Kroonprins (met diens eigen oepatjara vóór en ampilan achter zich) ${ }^{2}$ geheel voorop, dàn komen de oepatjara-draagsters van den Sultan, dàn, weer gearmd, Sultan + Resident, en dan de ampilan-draagsters; te Solo evenwel gaan des Soenan's oepatjaradraagsters geheel voorop, dan volgt de Ass.-Res. (rechts) + Kroonprins (links), dan volgen al de andere Prinsen in (losse) paren, en dàn volgt de Soenan (rechts) + Resident (links), terwijl talrijke ampilan-draagsters dit centrum van des Soenan's optocht naar en van den Sitinggil (uit van, en terug naar, de Bangsal Kentjånå in den binnen-Kð̣̦aton) sluiten.

1 Dit laatste „ornament" moet de "bòkòr widjikkan" (= wasch-bekken) zijn, door Deeleman 1.c. p. 359 als "een gouden kommetje" verklaard, en op zijn 8 e Plant afgebeeld. Voor de $\mathrm{katjoe} m$ as en koetoek, die in Jogja zelfs tot den rang van oepatjara zijn verheven (zie hiervóór blz. 107 en noot 1), zie zijn 6e Plaat; en verg. voor Jogja Groneman's Platen I $a$ en Ib (1888).

2 Volgens de strenge Jogja'sche Kraton-adat krijgt de Kroonprins die oepåtjårå pas vóór zich uit, als hij is getreden buiten de poort Dånåpěrti̊pa = Srimĕnganti in Solo (dus de $1^{\bullet}$ der 3 Noorder-poorten van den Kraton; van binnen naar buiten gerekend, zooals behoort); dus zich bevindt buiten de tj ${ }^{\prime}$ poeri (binnensten kratonmuur), daar waar zijn eigen, zij het dan ook titulair, gebied begint als Pangeran Adipati Anom $={ }_{r}$ jonge Prins-Vezier". Het Jav. Wdb. (1901, I, p. 565b) verklaart „Dånåpěrtåpa”" onvoldoende.

Dl. 77. 
De 4 andere Solo'sche oepåtjårå — de Gadjah, Garoe ḍa, Memreng, en Sěnoek - zijn de buitengewone, die misschien thans alleen den volke vertoond worden op een Garěbæg Moeloed Dal. Deeleman, de Controleur B.B., die in 1846 bij Nieuwjaarsdag 6 oepatjara en ca. 20 ampilan te Solo mocht nateekenen, heeft geen Memreng of Sěnoek onder oogen gehad, terwijl zijn opgaaf dat er "twee» olifanten toe behoorden (Bijdr. Kon Inst. 2 , II, 1859 , p. 358) een begrijpelijke vergissing is, omdat ook de Kroonprins er een heeft. Hoezeer ten deze Hof-gewoonten toch aan verandering ook onderhevig zijn, volgt uit wat RAFFLES (blijkbaar voor Solo, en voor ca. 1812) nog toevoegt aan zijn hiervóór (blz. 107, noot 2) overgenomen beschrijving van de door hem geziene 5 Solo'sche oepatjara: "When the sovereign moves abroad, he is attended by numerous spear-men (wáhos), the duty. of eight of whom is to attend the figures of the sacred elephant and bull, near which are also led four horses richly caparisoned. The royal paynung, or state umbrella, is carried in front of the procession on these occasions, ....: this rule is observed whenever the sovereign moves out of the palace» (1. c. p. 311). Hier had men dus het (heilige) getal van 8 piekeniers, om juist 'den Gadjah en den Memreng te omstuwen als symbolen der Staatsmacht.

Maar wie nu mocht meenen, dat deze Solosche rijkssieraden antiek zouden zijn in hun tegenwoordige vormen, behoeft DEELEMAN's eerste 5 Platen 1. c. maar te bekijken, om te weten hoe laat het is. Alléén die Garoeḍa kan een min of meer antiek stuk wezen; de 5 andere zijn alle moderne en machtelooze namaak, zelfs mis-maak (b.v. de Ardawalika is niet meer dan een gedrocht). Heeft Jogja soms in 1755 bij de splitsing van het Kartasoera'sche Mataram-rijk wel minder, maar daarentegen de authentieke 4 (Banjak ḍalang, Ardawalika, Mèndjangan en Sawoeng galing) gekregen, dan wel behouden ? ${ }^{1}$ Met name de Jogja'sche Ardawalika is een schitterend kunstwerk naast de gedrochtelijke Solo'sche; men zie maar Plaat I ${ }^{\mathrm{a}}$ en $\mathrm{I}^{\mathrm{b}}$ bij Groneman (1888)!

Zoolang echter de Memreng en de S ̌noek niet afgebeeld zijn, en evenzoo de Gadjah en Ardawalika van den Solo'schen

1 Heeft hierbij het meenemen van een deel der Mataramsche Rijksornamenten naar Ceilon in 1708 (zie hiervóór blz: 110 met noot 1) een rol gespeeld? Misschien zou de in 1901 door het Rijksarchief aangewonnen Collectie-Govert Cnoll (vaart eind 1709 thuis; sterft te Delft 21 Juli 1710).

Een arddhani = gouden Gans noemt V. d. Tuuk „onder de insignia van de(n) Dèwa Agung" (I, 1897, p. 106a). 
Kroonprins, zoolang er ook niet meer gegevens over die Solo'sche oepatjara ten dienste staan, èn over de insignia van den vroegeren Dewa Agoeng van Kloengkoeng, is het laatste woord over deze gewichtige materie allerminst tegemoet te zien.

Of het feit, dat Erlangga's ten slotte overwinnende Garoeda in den aanvang... op de vlucht is geslagen op Javaanschen bodem voor de vernielende horden van Woerawari, nog voortleeft in het taaie Jav. kroon- en wajangkapsel-symbool, den garoeḍa moengkoer (een "garoeda-achterste-voor»), is wel te vermoeden, maar nauweiijks te verzekeren. ${ }^{1}$ Doch het feit heeft tusschen 928 en 954 Caka bestaan. Terwijl Erlangga in 1030 A. D. (952 C.) eindelijk zijn grooten binnenlandschen vijand, den Vorst van Wěngk er $=$ Oerawan $=$ Gegelang $=$ Bahoewernå (= Madioen van thans) overwon, ${ }^{2}$ in 953, 954, en 957 Ç. nogmaals versloeg, en eindelijk in 1037 A.D. uit den weg wist te ruimen, was in $1032 \mathrm{~A}$. D. de Vorst van Woerawari - die, naar het mij schijnt, gemeene zaak had gemaakt met den Vorst van

1 Zie, behalve het interessante bij V. d. Tuuk, IV (1912), p. 672b over garuḍa mungkur (waar blijkt dat dit ornament ook voorkomt aan de Bal. kèțu of puntige priestermuts), wat Raffles zegt over het verschil van songkok (zie reeds 't slot der noot op blz. 111) gedragen door Soenan en Sultan: " that of the Susinan resembling what is distinguished by the term of the Madura hat in consequence of its being still worn by the Madúra family, and that of the Sultan having a golden garida affixed at the back, and two wings of gold extending from behind the ears" (History of Java, 1817, I, p. 92). Oók hier is dus de Jogja'sche hof-adat meer ouderwetsch dan de Solo'sche.

2 Zie over de gelijkwaardigheid dezer landschaps-namen V. d. Tuuk IV (1912), p. 836 b, i. v. bāhwābharaṇa, en verg. er p. $767-768$ i. v. gĕlang; ook I (1897), p. 116 i. v. urawan, en III (1901), p. 628-629 i. v. wĕngkĕr. Voor Wĕngkěr = de Panaraga-Madioen-vlakte, zie Van Stein Callenfels in Oudheidk. Verslag 1918, p. 74-81. Een zéér jonge historische plaatsbepaling van den Kraton te Gĕgělang is wel die van Von Hohendorff in zijn Dagregister dd. 8 Juli 1742, op zijn vlucht met Soenan Pakoe Boewana II van Kartasoera naar Ponorogo; 's morgens om 7 uur uit de kota Madioen vertrokken, ${ }_{n}$ quamen ten halv twaalv op Een plaats in 't bosch alwaar ten tijde doen Java in 4 koningrijken verdeelt was den ratoe galang sijn hoff.gehouden heeft" (Bijdragen Kon. Inst. 74, 1918, p. 602). Dit zijn dus de 4 Rijken: Djanggala, Gĕgělang, Daha, en Singasari (of Soerabaja, Madioen, Kĕdiri, en Pasoeroean), waarmede zoo te zeggen alle Pandji-verhalen (Javaansche èn Maleische) aanvangen, historisch teruggaande tot nazaten van Vorst Erlangga, die zijn rijk in der minne(?) verdeelden; terwijl we door twee inscripties (Pěnampikanplaten, 1191 Ç.; Mahāksobhya-beeld, 1211 Ç.) en door de Nāgarakrĕtāgama (1278 C.; Zang 68:1) weten, dat Erlangga nog tijdens zijn leven zijn rijk onder 2 zonen heeft verdeeld, resp. koningen van Djanggala en Pandjaloe (= Daha). 
Wengker - van het Javaansche tooneel verdwenen; zoogenaamd "vernietigd", dus zeker verdreven. Dit een en ander mag gelezen worden uit de, hoezeer dan ook nog fragmentarisch-ontcijferde, regels 21-30 der Oudjav. inscriptie van den Penanggoengan van 963 Ç., tegenwoordig te Calcutta. ${ }^{1}$ Daarbij bedenke men, dat een vroeger Vorst van Madioen, zetelend te Watoe Koera («Spits-Rots») = W. Tihang, Dyah Balitoeng (ca. 820-829 Ç.), een "water-massa» (jalasamūha) als zegelmerk droeg, dus misschien zelf iemand was van overzee! ${ }^{2}$

Maar pas nà Erlangga's dood kunnen Garoeḍa en Ardawalika tot Rijks-symbolen zijn geworden van den triomf door "Java, behaald over "Langka». Erlangga vergelijkt zich in 954 Ç. nog wel met "een vlammenden draak», die om zich heen likt tegen $Z$. M.'s vijanden (strofe 27 der Sanskrit-inscriptie, ook te Calcutta); maar in strofe 12 wordt zijn geboorte toch voorgesteld egelijk Rāma uit Daçaratha, (en) diens meerdere [dus: Oedajana's meerdere] door zijne voortreffelijke hoedanigheden», terwijl hij vervolgens (strofe 24) vertelt, hoe hij den aterling-Vorst ‘Adhamāpanuda genaamd, die als Rāwaña in persoon eene overgroote menigte van a dhamang a's (= "voeten»; soms = voet-knechten ?) bezat», voór 953 Çaka had verslagen. Hier ligt de Rāma-Rāwaṇa-symboliek in die Sanskrit-inscriptie van 959 C.. er zób dik op, als maar een eerst "vluchtende, Garoeḍa-Vorst, die daarna de vreemde

1 Het „oord Galuh" en het „oord Barat" (niet „Barut") in regel 22 (Kern, Verspr. Geschr. VII, 1917, p. 109), zouden, blijkens het Aardr. en Stat. Wdb. v. N.-I., I (1869), beide in Madioen, dus in oud-Wĕngkěr kunnen liggen, resp. in Patjitan en in Poerwadadi (nu: Maospati). Ook vraagt men zich af, of het onzekere "Magěhan(?)" in regel 26 niet moet worden gelezen: Magětan; en dan weer zou wijzen naar die bekende plaats in West-Madioen. -

Als inderdaad, zooals ik boven vermoedde, de Vorst van Wurawari (regel 24) zich, met zijn Langka-troepen, verbonden heeft met den Vorst van Wěngkěr (regel 21, 26), dan zou het bezwaar van Van Stein Callenfels (Oudheidk. Verslag 1918, p. 82-83) over Erlangga's grootdoennerij wel vervallen.

${ }^{2}$ Zie de inseriptie van 824 Ç. $=902 \mathrm{~A}$. D., met de aanteekening van Brandes uit 1898 , in O.-J. Oorkonden, ed. Brandes-Krom (1913), p. 31-32. Voor kura= kuwa = tihang (Watu Tihang staat in Balitoeng's oorkonde van 823 C; Wungkal Tihang in die van 828 en 829 C.., waarin w ungkal = watu; Watı Kurang in die van Balitoeng's opvolger Mahāçambhū uit 830 Ç.; o. c. p. 28-35)), zie V. d. Tuuk, II, p. 58a, 210a, 562. En Watu Kura is in 1287 Ç. nog een Boeddhistische pěrdikan-desa (Nāgarakrět. $77: 3$ ).

M. i. is deze plek thans... het Watoe Pațok (Jav. paţok = tijang= „paal”) op de grens van Patjitan met Ponorogo en Wonogiri, waar twee steenen voorkomen met tot nog toe onontraadselde inscripties (zie Verbeek's Inventaris der Hindoe-oudheden, 2ed., II, Rapp. Oudh. Dienst, 1915 (1918), p. 137). 
Konings-slang toch overmant, zich in het publiek mag veroorloven.

Het slot van deze rubriek $\mathbf{B}$, waarvan de ontwikkeling bij de uitwerking voor mijzelf een aanschakeling is geweest van verrassingen, moet dus luiden: tusschen ca. 900 en 1200 A. D. bestond er niet alleen een antiek Māhasin of Mahasin $\left(7^{\circ}\right.$ eeuw $)=$ Hasin $\left(10^{\mathrm{e}}-11^{\mathrm{e}}\right.$ eeuw $)=$ later Toemasik $\left(14^{\mathrm{e}}\right.$ eeuw $)=\operatorname{nog}$ later Singha-poera ( $15^{\circ}$ eeuw); maar er bestond daarnaast, in de buurt, op den uithoek van Galoeh's = Ratna's = Malaka's vastland, het nog véél oudere, hoogstwaarschijnlijk Boeddhistische, Langka (sinds de $1^{\circ}$ eeuw A. D.) $=$ Woerawari $\left(10^{\mathrm{e}}-11^{\mathrm{e}}\right.$ eeuw) = Ganggājoe (vóór 1450, doch pas gedocumenteerd in 1612) = Djohor (na 1530), het nu nog legendarische Mal. "Lěngka-soeka", met eene hoofdstad die in 928 Caka heette Lwarām, wat misschien evengoed als "Lief-water» is op te vatten (= Ganggāyu), als in den symbolisch-religieuzen zin van ‘Rām(a)'s Water» d. w. z. de Djohor-fjord, over getrokken door Rāma op zijn krijgstocht tegen "Lañkā».

Vrage opnieuw (zooals reeds bij blz. 123 werd gedaan): is niet Djohor een natuurlijke corruptie van Arab.-Mal. djauhar, c juweel,, en daardoor weer gelijk met Skr. Ratna=Galoeh, Ptolemaeus' "Aurea Chersonesus », ${ }^{1}$ het land van Goud óók nu nog?

1 Van de twee minerale schatten van 't Mal. Schiereiland, van oudsher tot heden toe, n.l. Tin en Goud, was K ĕd a h de oude uitvoerhaven van tin, terwijl het bovenland van $\mathrm{Pah}$ ang de groote vindplaats van goud is geweest en tot heden is gebleven, met daarnaast vroeger het gebied van den G. Ledang (alias Mount Ophir; op den Oost-uithoek van het gebied van Malaka). De oeroude suprematie van Kĕdah (zeg: sinds ca. 200 à 300 A. D.), de veel jongere (doch in de $14^{\circ}$ eeuw A. D., blijkens de Nägarakrëtāgama, voldongen) suprematie van Pahang, hingen onmiddellijk samen met deze twee mineralen.

Edelgesteente daarentegen komt niet voor op de Chersonesus, maar was van oudsher de specialiteit van West-Borneo (Lawe-Tandjoengpoera); evenals Java een "Goudland" echter heet te zijn van 654 Çaka af (Tjanggal-inseriptie) zònder zelf goud voort te brengen, maar door het te besitten, dank zij zijn suprematie, gesteund door handel in victualiën en scheepvaart (vooral op Timor en de Molukken), zoo kan de Chersonesus ook zeer wel oudtijds den naam hebben gekregen van edelsteen-rijk, door aanvoer van en handel in Westborneo'schen diamant. Maar een wezenlijk Goudland was, naast de Chersonesus, alléén van oudsher Sumatra; in welk laatste voor Malajoe = Djambi het bovenland der Batang Hari dezelfde minerale beteekenis had, als het bovenland van Pahang voor het eerste, met zijn machtige Soengai Pahang als afvoerweg.

De natuurlijke overgang van $\mathrm{Dj}$ a u har in $\mathrm{Dj}$ oh or (Balin. Djwar; oud-Port.

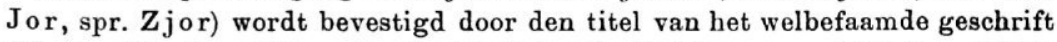
Djauhar Manikam (aldus Dr. Juynboll in zijn Catalogus van Mal. hss., 1899), 
Trouwens, nadat deze vraag neergeschreven was, bleek mij dat Valentijn in 1726, en Werndly in 1736 er al evenzoo over dachten wat Djohor $=$ Djauhar betreft. ${ }^{1}$

Van eene plaats Malaka is echter in deze eeuwen nog geen kwestie; laat staan van een emporium met dien naam.

\section{Het bestaan van Singapore, en de vermoedelijke geboorte van} Malaka tusschen ca. 1225 en 1292 A.D. (Toemapĕl's bloeitijd).

Aan den ingang van dezen tijd, waarin we vasten historischen grond onder de voeten voelen komen, staat sedert 1912 het toegankelijk gemaakte Chin. boekwerk van den Chef der douane te Ch'üan-chou (Marco Polo's "Zayton», N. O. van Emoi) CHAU JU-KUA, de "Chu-fan-chï» of ${ }^{\circ} \mathrm{chih}$ » van 1225 ; aan den uitgang staat de

in de Jav. versie geheeten Djohar Manikam (Vreede's Catalogus van 1892), in 1845 door De Hollander in zijn Mal. versie uitgegeven als Djohor Manikam, en dat, naar een aanteekening van V. d. Tuuk (Bijdr. Kon. Inst. 3, I, 1866, p. 449), op de Westkust van Sumatra geworden is tot: Djohor Malegan. Zie voorts het Kawi-Wdb. IV (1912), p. 385 over Djwar, en Djwar Manik in de Moh.-Balin. Sipat Iman Akung (en verg. ook Dr. Juynboll's Catalogus hss. Leiden, Supplement, 1912, p. 134-135).

1 Valentisn, zelf goed Malaicus, schreef in zijn "Beschryvinge van Malakka” (V, 1e Stuk, 1726, fol. 324b) over de stichting van Djohor door den uit Malaka gevluchten Sultan: „alwaar hy een nieuwe stad (zynde de derde door de Maleytse Koningen op dat land gebouwd [n.l. na Singapoera en Malaka]) aangelegd, gegrond-vest, en metter tyd voltoid heeft, gevende aan de zelve den naam van Djohor, misschien wel na 't Arabisch woord Djohor, dat een peerl, of ook wel de uiterlyke schoone gedaante van een mensch beteekend."

En Werndiy schreef 10 jaar later in de "Voorreden" tot zijne "Maleische Spraakkunst", met blijkbare gebruikmaking doch terens ook zuivering van wat Valentijn al geschreven had: „alwaar hy [n.l. de uit Malaka gevluchte Sultan] eene nieuwe stadt aangelegd, gegrondvest, en met den tydt voltooid heeft, gevende aan de zelve den naam van [volgen de 4 Arab. letters djim, wau, ha, ra] Djôhor, mogelyk wel naar het Arabische woordt [volgen dezelfde 4 letters] Djawhar, het welk een edelgesteente, of perel betekent." (p. XXX).

Dat er indertyd in Djohor - al was het dan zelf geenszins een Diamantland - een Diamantmarkt bestond (natuurlijk allereerst van West-Borneo'sche diamanten; waarbij de suprematie over die Westkust een gewichtige politieke factor was), blijkt aardig o.a. uit het feit dat op 3 Febr. 1609 Admiraal Willem Verhoeff (of Verhoeven), bij zijn vertrek uit "Iohor ofte Batusauwer" - versta: uit de stad Batoe Sawar, de toenmalige hoofdstad van het rijk Djohor - er in de Holl. loge achterliet: „Jacques Obelaer voor Opper-Coopman, Abraham Willemsz de Rijck voor Onder-Coopman ende [er staat foutief: ender] Hector Roos voor Diamant kender, nevens dry Assistenten ende noch eenige andere Persoonen" (Begin ende Voortgangh, 1645, II, 15e Stuk, p. 45a). Hier hebben we dus een Hector Roos - wel een Jood uit de jonge Diamantstad Amsterdam! - als vakman geplaatst op de Diamantmarkt Djohor-Batoesawar. 
tragische terugkomst van de Pamalajoe of Sumatra-expeditie, uitgezonden door Vorst Kërtanagara van Toemapel in 1275 A. D., teruggekomen op Oost-Java het jaar nadat Toemapel door Daha was ten onder gebracht en Kerrtanagara gedood ( $\uparrow 1292)$. De Jav. soldaten, "die Malayu waren gaan veroveren" (kang andon saking Malayu), ${ }^{1}$ zett'en in 1293 voet aan wal, toen Daha alweer op zijn beurt was overmand door de Chineesch-Tartaarsche expeditie van Koeblai Chān, die overwalsche veroveraars ook alweer door de op de loer liggende Javanen van Madjapahit in de pan waren gehakt (zomer 1293), en de zon van Madjapahit uit het bloedbad oprees. Van de twee Maleische prinsessen, levenden buit bij dezen tocht naar het Minangkabausche Gulden Vlies, ging de jongste den stamboom van Madjapahit's condottiere veredelen.

Van het zeer gewichtige door CHAU JU-KUA in 1225 geboekt over die 15 onderhoorigheden van het toenmaals in het Westen overmachtige Palembang, is hiervóór (blz. 92-93) al de lijst gegeven, met verbetering van eenige gelijkstellingen door Hirth en Rockhill voorgesteld of gevolgd. Die 15 bleken te zijn: 1. Pahang, 2. Trěngganau, 3. Lěngkasoeka (=Woerawari), 4. Kelantan, 5. Poelowan (de Kělang-delta?), 6. Djeloetoeng (hier wel $=$ Hasin), 7. Sermang (?), 8. Batak (op de Chersonesus?), 9. Tāmbralingga (Ligor), 10. Grahi (Jaiya), 11. Palembang (schijnt hier een onderdeel van San-fo-ts'i aan te duiden), 12. Soenda, 13. Kampe (Aroe), 14. Lambri (Groot-Atjeh), en 15. Ceilon ( $\mathrm{hm}$ !). De $12 \mathrm{~m}$. i. zekere identificaties werden gespatieerd gedrukt, de 3 onzekere gewoon. Pahang gaat hier reeds voorop; met Djëloetoeng schijnt oud-Singapore bedoeld te zijn, zooals op blz. 92 en 94 nader werd besproken; Lěngkasoeka is nummer drie, en dus blijkbaar al op den terugweg in macht.

Maar naast deze lijst der 15 onderhoorigheden van San-fo-ts'i (de "fifteen chóu», o. c. 1912, p. 60, met 62; welk getal precies klopt met het "The kingdom of San-bo-tsai ... rules over fifteen different countries» uit de Annalen der $2^{e}$ Soeng-dynastie, 960-1279, Groeneveldt, p. 62 of 187), geeft Chau Ju-kua óók een lijst der onderhoorigheden toenmaals van Su-ki-tan $=$ Djanggala!

Allereerst deze prachtige verrassing bij hem. Want men weet, dat reeds door de Notes van Groeneveldt $\left(1876\right.$, p. $54 ; 2^{\mathrm{e}}$ ed. 1887, p. 179), doch pas in 1618, een Chin. Su-kih-tan, of

${ }^{1}$ Aldus de Pararaton, ed. Brandes (1896), p. 24 regel 27 (tekst), p. 76 (vertaling). - Of thans, $2^{\circ}$ ed. Brandes-Krom (1920), p. 31 r. 27, en p. 92; zie ook p. 242 . 
Su-kit-tan, alias Su-kit-kang, bekend was geworden als een deel van Java "of which Grissé is the chief place». We wisten dus locaal precies waar we waren, maar terecht teekende Groeneveldt in zijn eerste noot aan: "This name has not been handed down by Javanese tradition».

Maar wat vertelt nu Chau Ju-Kua in 1225, dus 4 eeuw vroeger, leuk langs zijn neus weg? Sprekend over Shö-p'o = P'u-kialung (p. 75; dus Pĕkalongan) $=$ Fava (-proper), zegt hij aan 't slot: "Our Court has repeatedly forbidden all trade (with this country), but the foreign traders, for the purpose of deceiving (the government), changed its name and referred to it as Su-ki-tan s (o. c. p. 78). De slimme Zuid-Chineesche handelslui adopteerden dus een anderen naam voor hetzelfde, hun verboden, land; en bleven er op varen! Want Oudjav. soekĕt is "bosch", in 't Jongjav. "gras»(V. d. Tuuk, III, 1901, p. 127b); Soekětan dus=Alasan $=$ „Bosch-land = Wildernis = Djanggala, alias "Jungle».

En dat de Oudjavanen dit óók precies zoo hebben opgevat, blijkt uit de veelzeggende aanhaling bij VAN DER TUUK - voor wiens Woordenboek men steeds dieper eerbied krijgt, naarmate men er meer in werkt - : ssuketting djanggala, zou de vroegere naam van Padang kling [een kleine desa nu, O. ten $\mathrm{N}$. vlak bij Singaradja] geweest zijn, toen namentlijk de dal èm Bèdaulu [= de Vorst van Oer-Bali ? ${ }^{1}$ er nog zijn residentie had» (l. c.). Hier is "suket" en Djanggala met elkaar in dadelijk verband.

Steunend op Chau Ju-kua, durf ik dan ook gerust zeggen: al moge tot heden Suketan nog niet bekend zijn van Oudjav. inscripties als aequivalent van Janggala - iets, wat Dr. Krom mij onlangs mondeling bevestigde - zoo zal het te eenigertijd wel te voorschijn komen; want in (en dus al vóór) $1225 \mathrm{~A}$. D., was het onder de Chineezen een listig gebruikte synoniem voor Djanggala; of zeg duidelijkheidshalve: voor het gewest Soerabaja van thans, locaal gesproken; voor Oost-Fava in ruimer-politieken zin.

Met deze eerste verrassing is het allerminst uit. Nu gaat Chau Ju-kua dit Su-ki-tan - door Hirth \& Rockhill, p. 82, minder juist met "Central Java" gelijkgesteld - nader beschrijven

1 Hoe "Bèda-ulu" precies op te vatten is - „Die wegtrok naar 't bovenland"? - blijft onzeker (ook na den uitleg bij V. d. Tuuk, IV, p. 923-924), omdat deze Vorstennaam behoort tot de verdacht-historische berichten der Pamantjangan en Oesana Bali; volgens IV, p. 616a, zou de heuvel Mangoen, W. van den G. Agoeng, alwaar de tempel S a mw an Tig a staat (III, p. 335b), de berg-residentie van dien Vorst zijn geweest. 
(p. 82-83), en daarbij zegt hij: *This country is adjacent to the following countries, all of which are dependencies [nota bene!] of Shö-p'o [= Java-proper]» (p. 83). Volgt in de editie1912 een lijst van ó́k 15 Chin. namen, waar Hirth en Rockhill bitter weinig van hebben thuisgebracht; en waaraan ook PELliot in zijn prachtige bespreking (T'oung Pao, XIII, 1912, p. 446-481) zich niet heeft gewaagd, maar alleen daarvan neerschreef: "La question des „états" soumis à Java reste fort obscure; elle s'éclairera cependant en grande partie quand ou comparera les indications assez nombreuses de l'Histoire des Yuan, le texte de Tchao Jou-koua et le Tao yi tche lio.» [of in niet-Fransche transcriptie: Tao $i$ chilh lio, van Wang Ta-yüan uit $1349 ;{ }^{1}$ door Rockhill later in T'oung Pao, XVI, 1915, p. 61 vlg. nader bewerkt] (p. 469).

Laat ik dan trachten die lijst zooveel mogelijk hier thuis te brengen, waarbij tevens profijt kan worden getrokken van een vroegere bespreking door Prof. Schlegel in T'oung Pao, Sér. 2, IV (1903), p. 238-239, al moet men daarmee dan ook uiterst voorzichtig omgaan. ${ }^{2}$ Er zullen dan blijken 14, en niet 15, onderhoorigheden van Shö-p'o = Java-proper, politiek besproken "Oost-Java», genoemd te worden : ${ }^{3}$

1. Pai-hua-yüan [ligt op Shö-p'o zelf, zegt Chau p. 222, en brengt peper voort; gelijk ók geldt voor $\mathrm{n}^{\circ} .2, \mathrm{n}^{0}$. 3 , en $\mathrm{n}^{0} .5$, zie hieronder de noot ${ }^{4}$ ] (= Patjitan ?, dat in de $17^{\mathrm{e}}$ of $18^{\mathrm{e}}$ eeuw een belangrijk peperland was voor de O. I. Comp.); 2. Ma-tung (= Mẹ̣ang??, en dan = Mataram); 3. Ta-pan (=Toemapěl); 4. Hi-ning [dit schijnt ook op Java te liggen, naar de volgorde;

1 Zie hierachter sub D, blz. 154-158, een zeer belangrijk gegeven over Toemasik in ca. 1340, aan dit werk ontleend.

"Van dit opstel "Geographical Notes, XVIr. Java. I" (A. D. 414-begin 13e eeuw), 1. c. p. $228-250$ - het laatste dat Schlegel († 15 Oct. 1903) heeft geschreven - kon ik, met mondelinge nadere mededeelingen van den heer Groeneveldt ( $\dagger 18$ Aug. 1915), nog gebruik maken voor het stukje over Chau Ju-kua in het art. "Tochten (Oudste Ontdekkings-) tot 1497", in Encycl. v. N. I., 1en druk, IV (1905), p. 376. Daar werd, naast het door Schleger herkende Djanggala, Bali, Timor, ook reeds thuisgebracht: Toemapĕl, Goeroen, Tandjoengpoera (inderdaad op Borneo), en Banggaai. Feitelijk wordt hierboven dus alléén $\mathrm{Wu}-\mathrm{nu}-\mathrm{ku}=$ Moloekoe $=$ Ternate met zekerheid nader herkend.

s De herkende inlandsche namen worden hieronder gespatieerd, de onzekere gewoon gedrukt.

4 L.c. p. 222: ${ }_{n} H u$-tsiau [= pepper] comes from the following places in Shö-p'o: Su-ki-tan, Ta-pan, Pai-hua-yüan, Ma-tung, and Jung-ya-lu; but the pepper coming from Sin-t'o is the best; the Ta-pan variety takes the second place." 
en bij den klank denkt men van zelf even aan den Diëng]; 5. Jung-ya-lu (= Djanggala; hier op dezelfde wijze als "onderhoorigheid» van "Java» wel genoemd, als «Pa-lin-föng»= Palembang een onderhoorigheid bij hem heet van San-fo-ts'i); 6. Tung-ki (= Djenggi??, en dan = Nieuw-Guinee); 7. Takang [is, mèt $\mathrm{n}^{\circ} .12$, het land van sandelhout, zegt hij p. 208, zie hieronder de noot ${ }^{1}$ ] (= Larantoeka ??); 8. Huang-ma-chu [hiervandaan, in achtergelegen eilanden, komt de nootmuskaat, zegt hij p. 210; gelijk óók geldt voor $\mathrm{n}^{\circ} .10$, zie hieronder de noot ${ }^{2}$ ] (= Mangkasar ?); 9. Ma-1i (= Bali); 10. Niu-1un [in de bijbehoorende latere Chin. aanteekening geheeten $\mathrm{Ku}$ $\mathrm{lun}$, en een zeeroover-staat, evenals $n^{\circ \mathrm{s}}$. 11,9 , èn Sun-t'a $=$ Soenda; zie hieronder de noot ${ }^{3}$ ] (= Goeroen, Gorong, Goram); 11. Tan-jung-wu-lo (= Tandjoeng-poera, op Z. W. Borneo); 12. Ti-wu [verg. no. 7] (= Timor); 13. Ping-ya-i (= Banggaai, Z.O. Celebes); 14. Wu-nu-ku (= Moloekoe, d. i. Molukke-proper, Ternate). ${ }^{4}$

Ten overvloede zegt hij nog op p. 84: "The countries of Ta-kang, Huang-ma-chu, Ma-li, Tan-jung-wu-lo, Ti-(wu), Ping-ya-i

1 L. c. p. 208: T"an-hiang [= sandalwood] comes from the two countries of Ta-kang and Ti-wu; it is also found in San-fo-ts'i." - Dat, naast Timor, steeds Solor (maar niet Tjĕndana = Soemba) genoemd wordt in ca. 1600 als land van sandelhout, mag hierbij herinnerd worden.

${ }^{2}$ L. c. p. 210: „Jio-tiu-k'óu [= nutmegs] are brought from the foreign tribes in the depths of the islands of Huang-ma-chu and Niu-lun." - Bij Huang-ma-chu zou men, naar den klank, ook zeer goed kunnen denken aan een Oudjav. wwang Badjo of Badjoreezen, Wadjoreezen (verg. V. d. Tuuk, IV, p. 1012), wat dan toch ook op Zuid-Celebes zou uitkomen. Mangkasar was van ea. 1600 tot heden een verzamel-, en dan uitroerhaven van allerlei producten der Groote Oost (ook van Timor, met zijn sandelhout en thans ook koffie).

${ }^{3}$ Deze noot, vermoedelijk "by the Ming editor of the Chu-fan chi" (p. 86, noot 9), d.i. dus uit 1407, zegt: „(By „pirate states”, Tan-chung-pu-lo, Pa-li, Sun-t'a and Ku-lun are to be understood)."

4 Voor $n^{\circ s}$ 13-14 volg ik Schlegel (l.c., 1903, p. 239), die gaf: „P'ing-gâ-i and But-no ko", dus 6 Chin. karakters in twee namen verdeeld; en niet Hirth \& Rockhill, p. 83 , die ze als $\mathrm{n}^{\text {os }} 13-15$ splitsen in 3 namen (Ping-ya, I-wu, en $\mathrm{Nu}-\mathrm{ku}$ ), er bij herinnerend dat Schlegel "divides the last six cliaracters in the list into two names only" (p. 86, slot van noot 7). Aangezien de Chin. tekst géén getal noemt voor de "dependencies of Shö-p'o" - in tegenstelling tot het getal 15 der onderhoorigheden van San-fo-ts'i = Palembang - , kan het eene evengoed als het andere juist zijn. Bij splitsing in tweeën krijgt men 2 duidelijk herkenbare Moluksche namen. Reeds BLAGDEN had in zijn stukje ${ }_{n}$ Some remarks on Chau Ju-kua's Chu Fan Chi" (Journ. R. As. Soc. 1913, p. 165-169), in diens tekst een Wu-nu-ku= the Moluccas" gezocht (p. 167-168). 
and Wu-nu-ku are situated on islands; ${ }^{1}$ each of them has its own chief, and they have vessels plying between them. There is but little agriculture, but there are many old trees, the inner parts of which produce sha-hu (sago), which looks like wheat flour. The natives by mixing water with it, make it into pellets of the size of peas. After being sun-dried it is packed up and stored like grain ..... The natives (of these countries) are strong fellows, but savage and of a dark bronze colour..... As a standard of exchange the people use only pecks and pints [op z'n Indisch ongeveer: gantang's en kati's] of sago.... The native products include sandal-wood, cloves, cardamoms [juister zou hier zijn: nutmegs], fancy mats [versta wel de kokoja's, of Moluksche pandan-matten], foreign cotton cloth [wel vooral uit Bali], iron swords and other weapons [gewis uit Banggaai en verder Celebes]». Maar over Bali en Tandjoengpoera geeft hij aan 't slot dezer beschrijving van $\mathrm{Su}-\mathrm{ki}-\mathrm{tan}$ nog de volgende goede, deels ook kwade getuigenis: "Among these islands those of Tan-jung-wu-lo and Ma-li are rather more extensive than the others; they raise large numbers of horses for military service and they have a slight knowledge of writing and counting. The native products are laka-wood [versta: 'stoklak; zie er toch p. 211], yellow wax, fine aromatic substances and tortoise-shell. Although Tan-jung-wu-lo has such products, the people instead of attending to (legitimate) business, prefer going to sea for piracy, and so foreign traders rarely come there.» (p. 84-85).

Zoo schijnbaar onbevredigend dit terechtbrengen der 14 Chin. landsnamen van Chau Ju-kua ook moge wezen, omdat maar 8 onbetwistbaar mogen heeten, en naar de andere 6 hoogstens gegist kan worden, zoo verrassend is toch de uitkomst.

Wat toch blijkt? Oud-Middenjava (Shö-p'o = P'u-kia-lung $=$ het latere $\mathrm{Ngastin} \AA^{2}$ der jong-Javanen), hetwelk de hegemonie

1 Gewijzigd naar voorgaande noot. Hirth \& Rockhill hebben hier weer: n..., Ping-ya, I-wu and Nu-ku are situated on islands".

'Merkwaardig is zeker, dat Chau Ju-kua's zeggen uit 1225: "The kingdom of Shö-p'o, which is also called P'u-kia-lung" (o.c. p. 75) - welke laatste naam in de Ming-Annalen werd overgenomen, en daarin door Groeneveldt terecht herkend als P ěkalongan (Notes, 1876, p. 40; of $2^{\bullet}$ ed. 1887, p. 166) zoo sterk ineengrijpt met de meening der Javanen uit 1750-1850, dat het Ngastinå of Hastinåpoerå van hun Bråtåjoedå, als zetel van het rijk der Koråwå's, identiek zou zijn met het moderne Pěkalongan.

Bekend is, dat Raffles in zijn History of Java, 1817, I, p. 411, dit reeds vermeld heeft, en in zijn kaartje tegenover p. 412 heeft opgenomen. Maar 
had moeten afstaan in ca. 930 A. D. aan Jong-Oostjava (Su$\mathrm{ki}-\tan$ ), had in 1225 buiten. Java-zelf (waarvan alleen de gewestnamen Tocma p̌el en Djanggala zonder fout te herkennen zijn) een overzeesch gebied aan zich onderhoorig gemaakt, dat zich uitstrekte over den zes- of eigenlijk vijfhoek: Bali-Timor-GoramTernate-Banggaai-Tandjoengpoera. D. w. z.: over de Kleine Soendaeilanden (met o. a. ook "Ta-kang", een sandelhout-eiland), de Molukken, Midden-Celebes (met ook Zuid-Celebes?), en ZuidwestBorneo. - Noord-Borneo ( $\mathrm{P}^{\prime} \mathrm{o}-\mathrm{n} \mathrm{i}=$ Broenai) met zijn 14 eigen, helaas niet met name vermelde, onderhoorigheden viel er echter beslist buiten. ${ }^{1}$

belangwekkender getuigenis is het volgende uit den laat-18-eeuwschen Jav. roman Adji Såkâ, ed. Gaal-Roorda, 1857, p. 8, r. 3-9: „Sarĕng Adji Saka sampoen andjadjah nagari Bangwetan $[=$ Oosthoek van Java], sarta anjangkalani [ = maakte een chronogram op] sakaţahing rĕdi ingkang dipoenambah; ladjěng wangsoel mangilen oeroet Pasisir malih: andjog ing Bantěn, ing Djakarta, ing Karawang, ing Tjarěbon, ing Brěběs, ing Těgil, ing Ngastina [hier dus Kråmå voor Pěkalong an! Roorda.Vreede, 1901, II, p. 792b, is onvoldoende], ing Batang, ing Kĕṇdal, ing Kaliwoengoe, ing Sĕmawis; anoentĕn ngambah sěgantĕn ngantjik ing poelo Kelor [ = het eilandje Kerkhof, bij Onrust, reede van Batavia; niet bij Roorda-Vreede], wontěn ing ngrikoe kendĕl."

Daar Pĕkalongan reeds vóór 1225 een dusdanigen naam had onder de Chineezen, een goed opvaarbare rivier bezit, en de toegang is tot een noordelijken bergweg naar den Diëng, mag het bestaan dezer plaats vóór $950 \mathrm{~A}$. D., dus in den Mĕdang-Mataram-tijd, of (in jong-Jav.) den Mĕṇ̦ang-Kamoelan-tijd, wel buiten twijtel worden geacht. In de rivier van Pĕkalongan is voorts in 1899 een bronzen keteltrom gevonden, evenals er een van den Diëng sinds lang bekend was, terwijl er in 1909 een in het Pĕmalangsche werd gevonden; zie mijn art. „Keteltrommen (Bronzen)" in Encycl. van N. I., 2 ${ }^{\text {en }}$ druk, II (1918). Oók dit pleit voor hoogen ouderdom van Pěkalongan, zelfs van vớr de alleroudste inscriptie op Java (Tjanggal in Zuid-Kĕdoe, 654 Çaka = 732 A. D.).

1 De beschrijving van P'o-ni bij Chau Ju-kua (o.c. p. 155-159) is zeer interessant, omdat zij den vollediger tekst geeft van wat de Annalen der $2^{\circ}$ Soeng-dynastie (zie bij Groeneveldt, 1876, p. 108-110; of $2^{\mathrm{e}}$ ed. 1887, p. 229-231) verkort hebben overgenomen, deels met inwerking van een enkele verbetering of toevoeging; een 55 jaar nà hem dus. In beide teksten wordt P'o-ni gezegd te regeeren over 14 landschappen (of: steden, plaatsen), waarvan de namen niet worden vermeld. Aan het slot geeft echter Chau Ju-kua in 19 Chin. karakters de namen van diverse "ocean islands" - hun getal wordt niet genoemd -, wier inwoners handel dreven met kleine schuiten, en in leefwijze analoog waren aan de Broenai-lieden (p. 157-158). Aan deze lijst moge men zijn krachten eens beproeven: Si-lung-kung-shï-miau-jïli-hu-luman-t'ou-su-wu-li-ma-tan-y ü-ma-jö.

In njï-li-hu" zien Hirth \& Rockhill: Gilolo (p. 159). Inderdaad schijnt Djailolo in "jï-li-hu-lu" te schuilen. En kunnen in de laatste 7 syllaben soms schuilen de namen Karimata en Djëmadja? De verdeeling dezer 19 karakters in 8 landsnamen bij H. \& R. is "purely tentative", erkennen zij zelf (Note 15). 
Maar daarnààst, aldus zagen we hiervóor, beheerschte de staat Çrī Widjaja (San-fo-ts'i), met als centrum Palembang (Pa-linföng), het geheele Maleische Schiereiland (behalve met name Kedah), een goed deel van Sumatra's geheele Oostkust (doch niet Baroes $=$ Fantsoer, en de verdere Westkust), èn . . . West-Java (Soenda). Over Ceilon mag gezwegen.

Er liep dus in 1225 A. D., bij 't begin van Toemapel's bloeitijd, een geografisch-politieke scheidingslijn dwars door de Fava-Zee, en over de westerhelft van Java-zelf, heen, die de twee Grootmogendheden van toenmaals in Indonesië scheidde: Oost-Java en Palembang.

De heele opzet nu van de zgn. Pamalajoe, op bevel van Vorst Kertanagara van Toemapel in 1197 Çaka $=1275$ A. D. uitgetogen, was dus - zooals we nu pas door den kostbaren tekst van Chau Ju-kua kunnen beseffen! - die politieke scheidingslijn te doorbreken, en Java oppermachtig te maken óók in het Westen van den Archipel, waar Palembang den baas speelde.

Zoo komt Kertanagara's schijnbaar incidenteele expeditie naar Minangkabau - het hart van Midden-Sumatra, waarheen men doordrong langs oer-Malajoe $=$ Djambi heen, en de machtige Batang Hari op - in een totaal-nieuw licht te staan.

De uitwerking van deze expeditie over volle 18 jaar (1275-1293 A.D.) moet geweldig zijn geweest, hoe episodisch-onbeduidend de Pararaton haar ook moge vermelden. ${ }^{1}$ Het was het praeludeeren op de groote politiek in den bloeitijd van Madjapahit, een goede halve eeuw later. Als over dezen Sumatra-tocht eens speciaal een historisch Oudjav. relaas nog te ontdekken ware!

Waar was $\mathrm{Hasin}$ of $\mathrm{Mahasin}$ in dezen tijd aan toe? Was de naam Toemasik al geboren?

Het zou niet mogelijk wezen op deze twee vragen een eenigszins vertrouwbaar antwoord te geven, als we niet het kostbaar getuigenis hadden van Marco Polo juist uit het slot dezer Toemapelperiode, begin 1292. Voor kort begrip mag ik hier herhalen wat ik in 1904 in 't artikel "Tochten (Oudste ontdekkings-) tot 1497 schreef in de Encycl. van N. I., $1^{\text {en }}$ druk, IV (1905):

1 Amende honorable maak ik voor de ongelukkige uitdrukking "de totaalvruchtelooze Pamalajoe" uit 1904, in het art. "Sumatra (Geschiedenis tot 1596)", Encycl. v. N.-I., 1 ${ }^{\bullet}$ ed., IV (1905), p. 207a. De beelden en inscripties sedert 1907 aan de boven-Batang Hari gevonden, hebben wel anders geleerd! Men zie hierbij de juiste opmerking in noot 1 bij Ferrand, II, p. 70. 
"Polo zeilt met een Chin. smaldeel, dat naar Perzië ging met teedere opdracht - een Chin. prinses werd van Kanbalik = Peking overgebracht als gade voor Arghoen Khan, vorst van Perzië — in eind 1291 [met den N. O. moeson] van "Zayton»= Ch'ïan-chou in Foekhiën, voorbij "Chamba" = Tjampa, langs «Sondur» en "Condur» = Poeloe Condor of (?) Koendoer (= Kalebas-eiland?) tegenover den mond der Mekong, voorbij "Locac" = waarschijnlijk Zuid-Siam (Lo-hoh of Lo-kok), naar "Pe n t a m» = Bintan, waar hij in een ondiepe "channel», een sĕlat bij Oedjoeng Tanah en Singapoera komt, en nu de groote Sělat, Straat Malaka, inzeilt.»(p. 378a).

Marco Polo weet dus niets in ca. Jan. 1292 van een Hasin of Mahasin of Toemasik of Singapoera; terwijl hij uitdrukkelijk Bintan beschrijft als "an island called Pentam, a very wild place» in het volgende opmerkelijke zinsverband:

"When you leave Loc ac and sail for 500 miles towards the south, you come to an island called Pentam, a very wild place. All the wood that grows thereon consists of odoriferous trees. There is no more to say about it; so let us sail about sixty miles farther, between those two [sic!] Islands. Throughout this distance there is but four paces' depth [4 Venetiaansche passi van elk 5 piedi $=$ ca. 6 M.] of water, so that great ships in passing this channel have to lift their rudders, for they draw nearly. as much water as that.

And when you have gone these 60 miles, " [nu volgt wat reeds op blz. 4 hiervóór omtrent de ligging van "Ma laiu r " = bij Marco Polo: Palembang, werd afgedrukt]. (ed. YuleCordier, 1903, II, p. 280).

Men weet, dat dit "Locac» (var. Lochac) tot heden toe een crux is gebleven, en slechts met moeite door Yule teruggebracht is tot een Lo-hoh of Lo-kok = Zuid-Siam, zooals men l. c. p. $277-280$ in Note 3 kan nalezen. En hier, bij dat zeilen der Chin. vloot tusschen "Locac» en "Pentam» door, zat men weer met die moeilijkheid wat toch dat "Locac» was, gelijk men 1. c. p. 281 in Note 2 bij Yule kan nalezen. Alleen door het volstrekt duidelijke verloop der zeereis - van Tjampa's Zuidkust over Poeloe Condore of Condor (ca. $8^{\circ} \frac{1}{2}$ N. Br.) naar Bintan (ca. $1^{\circ}$ N. B. $)$ - wist men precies wààr men het zoeken moest: 
ergens aan de groote kustlijn van de Golf van Siam, Ptolemaeus' Groote Golf.

$\mathrm{Nu}$ er licht is opgegaan over de ware ligging van het oude Langka, en de hegemonie die dit oude Lěngka(soeka) in de Djohor-fjord sinds ca. $100 \mathrm{~A}$. D. heeft uitgeoefend over de Zuidelijke helft van het Maleische Schiereiland, wordt ook deze duistere plaats over "Locac, bij Marco Polo duidelijk. Na het verlaten van “Chamba» $=\mathrm{Tjampa}^{1}$, versta men dan bij hem als volgt:

"When you leave $\mathrm{Chamba}$ and sail for 700 miles on a course between south and south-west, you arrive at two Islands, a greater and a less. The one is called Sondur and the other Condur [ = de Pulo-Condor-eilanden; Arab.-Perz. Čundur-fūlāt, Șundur-fūlāt, zie Ferrand's Relations de Voyages etc., I, 1913, p. 40 noot 6]. As there is nothing about them worth mentioning, let us go on five hundred miles beyond Sondur, and then we find another country which is called Locac [= Langka!]. It is a good country and a rich; [it is on the mainland]; ${ }^{2}$ and it has a king of its own. The people are Idolaters [versta wel: Boeddhisten] and have a peculiar language [i. e. Maleisch], and pay tribute to nobody, for their cosntry is so situated that no one can enter it to do them ill [de Djohor-fjord!]. Indeed if it were possible to get at it, the Great Kaan [= Koeblai Chān, 1260-'95] would soon bring them under subjection to him.

In this country the brazil [Caesalpinia Sappan L., sapanhout] which we make use of [dus: in Italië, n.l. voor roodverven] grows in great plenty; and they also have gold in incredible quantity [Ptolemaeus' Aurea Chersonesus ! vooral goud uit $\mathrm{Pahang]}$. They have elephants likewise [waarvoor $\mathrm{K} e ̀ \mathrm{dah}$ van oudsher tot nu toe befaamd was], and much game. In this kingdom too are gathered all the porcelain shells which are used for small change in all

\footnotetext{
1 De hss.-teksten hebben hier alle: Java (zie Yule-Cordier, II, p. 269 en 276 noot 1); een begrijpelijke schrijffout, omdat Polo vlak daarvóór het „great Island called Java" als excursie was gaan beschrijven, bij zijn verhalen over het groote land "Chamba". De tekst-correctie is van Pauthier's uitgave (1865, II, p. 562), en door Yule overgenomen.

2 Deze 5 woorden zijn ingevoegd door Yule uit den Italiaanschen tekst van Polo bij Ramusio, dl. II (1 ${ }^{\circ}$ ed. 1559 , fol. $\left.51 \mathbf{v}^{\circ}\right)$ : ch'è di terra ferma.
} 
those regions, as I have told you before [over deze porcellani, kauri's, cowries, Cypraeae monetae, zie Yule \& Burnell's Hobson-Jobson i. v. Cowry; Polo had er al over verteld bij *Carajan»=Yün-nan, o. c. II, p. 66, 76; het zijn de Mal. beja-beja, waarvan het enkelvoud zelfs "tolgeld, cijns, belasting» later is gaan beteekenen, waarvan dan weer Pabejan $=$ Tol-kantoor].

There is nothing else to mention except that this is a very wild region, visited by few people; nor does the king desire that any strangers should frequent the country, and so find out about his treasure and other resources. We will now proceed, and tell you of something else., (1.1. p. 276).

En nu volgt onmiddellijk bij Polo dat over "Locac»-«Pentam» van hierboven. Is het niet de natuurlijke opvatting bij Polo's onverzorgden verteltrant, dat die "two Islands " waar hij hier zegt tusschendoor gevaren te zijn, waren: het uiteinde van dat land "Locac en dat wilde eiland «Pentam», m. a. w. Oedjoeng Tanah en Bintan? Zóó vatten, sinds Yule ( $1^{\mathrm{e}}$ ed. 1871), allen het ook op; en zoo zegt het zelfs de Ital. tekst van Ramusio sedert 1559. ${ }^{1}$ Wanneer men dan nu onder dit «Locac» niet Zuid-Siam, maar wèl Langka= de Zuiderhelft der Chersonesus, wil gaan verstaan, dan kloppen Polo's afstanden bovendien goed, door den natuurlijken uitleg dat de Chin. vloot vóór den wind (den N.O. winter-moeson) van P. Condor Z.W. aanstuurde op «Locac's » kust (500 mijl), en in zicht van die kust op de hoogte van ongeveer Trĕngganau, ${ }^{2}$ nu bij den wind langs die kust Z. Z.O. verder zeilde, naar de "channel» bij Bintan (weer 500 mijl), welke "channel»-zelf $60 \mathrm{mijl}$ lang heet te zijn. Alleen de daarna aangegeven afstand tot "Malaĭur» is dan veel te klein, immers slechts $30 \mathrm{mijl}$; doch zie daarover reeds hiervóór blz. 8-9.

$\mathrm{Er}$ is "dus goede reden om in Polo's "Locac» te zien den vastelandsnaam Langka, ook al erkent men ten volle dat die ver-

1 De tekst luidt: ${ }_{\text {P }}$ artendosi di Lochac, si nauiga cinquecento miglia per mezzo di, \& trouasi vna Isola chiamata Pentan,... \& \& fra la prouincia di Lochac, \& l'Isola di Pentan per miglia sessanta in molti luoghi non si troua acqua se nõ per quattro passa alta. \& per questo bisogna, che li nauiganti leuino piu alto il timone" (II, fol. $51 \mathrm{v}^{\circ}$ ).

2) Hierbij moet dan het oude P. Bĕrhala = thans P. Tenggol, voor de kust van Trĕngganau, (284 M. hoog) tot baken hebben gediend; hierna sub D (zie blz. 163), en in ous IIe Gedeelte sub V, nader besproken. 
draaiïng van naam haar wezenlijke bezwaren houdt. Maar overigens komt alles prachtig uit, zooals hierboven reeds werd aangegeven tusschen groote haken; ook de onvriendelijkheid jegens vreemden in dezen (vermoedelijk Boeddhistischen) Zeeroovers-staat.

Maar noemt Polo Langka waarschijnlijk, en Bintan gewis, van een Singapore, onder welken naam ook, weet hij in 1292 niets. Het moet tijdelijk, waarschijnlijk al ettelijke jaren, verlaten terrein zijn geweest.

Wat ligt hier méér voor de hand, dan dat de in 1275 uit Oost-Java - vermoedelijk Toeban, ${ }^{1}$ of anders uit oud-Sedajoe dan wel Soerabaja - onder zeil gegane expeditie naar Midden. Sumatra tijdens haar lang verblijf in deze streken geducht heeft huisgehouden onder zwakkere tegenstanders op de Bangka-LinggaRiouw-eilanden? Komt hier niet in zijn natuurlijk historisch verband te staan Verhaal V der Sadjarah Melajoe, hiervóór (blz. 2930) reeds kort besproken, over een éérsten, doch vruchteloozen, aanval van een "Batara Madjapahit» op "Singapoera», met een groote vloot onder een "hoeloebalang», die genoemd wordt "Demang Wiradja»? Vooral ook, omdat in den aanhef van dat Verhaal $\mathrm{V}$ zoo onloochenbare, hoezeer verhaspelde, herinneringen voorkomen aan die $\mathrm{Pam}$ a lajoe, door te vertellen van den voorafgeganen "Batara Madjapahit, die twee zonen had gekregen bij eene dochter ("anak») van den «Radja Boekit Si-Goentang» (dus: Minangkabau), en waarvan nu de oudste zoon, genaamd "Raden Inoe Mrrtawangsa", die zijn vader na diens dood gevolgd was op den troon van Madjapahit, dezen aanval op "Singapoera», in zijn expansie-politiek over de "sěgala radja-radja Noesa-Tamara» [ $=$ Noesantara], had ondernomen (zie Shellabear, 1898, p. 26; en verg. blz. 30 hiervóór), waarvan de helft ("sa-těngah*) hem al onderworpen wàs.

Het is de éérste maal bovendien, dat in de Sadjarah Melajoe verband wordt gelegd tusschen "Madjapahit » en «Singapoera » nadat alreeds in Verhaal II (verg. blz. 30-31) de bloedsvermenging tusschen "Madjapahit en "Sang Sa-poerba * van den *boekit SiGoentang Maha-meroe» zóó was voorgesteld, alsof een «Batara ,

1 Uit Toeban is de beschreven steen, zonder jaartal, maar met de garudamukha als zegelmerk - dus wel uit Erlangga's tijd -, waarin „eenige privilegies verleend (worden) met het oog op den handel over zee" (Oudjav. Oorkonden, ed. Brandes-Krom, 1913, p. 253). En in 1293 is Tu-ping-tsuh = Toeban, de zeehaven waar het eerste deel der Tartaarsch.Chin. legers aan wal gaat. Dl. 77. 
van M. uit nieuwsgierigheid naar Tandjoengpoera ( $\mathrm{Z}$. W. Borneo) was getogen om Sang Sa-Poerba aldaar bij diens tijdelijk verblijf te kunnen ontmoeten, er diens dochter "Tjandra Dewi» had gehuwd, met deze gade terug was gekeerd naar M., uit welken echt nu: "sjahadan daripada anak-tjoetjoe Baginda itoelah $[=$ die Batara] toeroen-těmoeroen djadi radja di Madjapahit»(Shell. p. 19). Al wordt dus in den aanhef van Verhaal $V$ de naam van de Minangkabausche "anak» niet opnieuw genoemd, zoo blijkt uit Verhaal II dat zij voor den Maleischen auteur en zijne lezers die "Tjandra Dewi» was, moeder daarop geworden van "Raden Inoe Mertawangsa » bovengenoemd, die na zijn troonsbestijging heerschte over "geheel Java" (sa-loeroeh tanah Djawa), en nu blijkbaar ook de àndere "helft" van de Noes anta $\mathrm{ra}$, die hem nog niet gehoorzaamde, onder zijn oppermacht wilde krijgen. ${ }^{1}$

Dit Maleische zeggen in of vóór ca. 1612 (waar men anders overheen zou lezen) sluit weer zóó prachtig aan bij wat we sedert 1912 uit Chau Ju-kua kunnen zien dat in 1225 A. D., bij den aanvang van Toemapell's bloeitijd, de feitelijk-politieke toestand was, dat we, in verband met wat wij thans over de Pamalajoe weten, en met wat het negatieve getuigenis van Marco Polo uit 1292 A. D. ons leert, aldus mogen combineeren:

$1^{\circ}$. tusschen 1275 en 1292 - en dan waarschijnlijk veeleer dicht bij 1275, dan dicht bij 1292 - heeft de Minangkabauexpeditie van Vorst Kertanagara van Toemapěl óók Mahasin = $\mathrm{H}$ as in $=$ oud-Singapoera, aangevallen en vernield - contra de opgesierde voorstelling van Verhaal V der Sadj. M. -; en zóó grondig tijdelijk vernield, dat Polo van geen stad of staat weet, tegenover zijn eiland «Pentam» gelegen.

$2^{\circ}$. het juist wèl noemen van dat eiland «Pentam» door Polo, zij het als "a very wild place», doet het natuurlijk vermoeden aan de hand, dat Bintan zijn later telkens herhaalde rol bij deze katastrofe had vervuld: toevluchtsoord te worden voor deze verdreven Maleiers.

1 Deze gewichtige tekstwoorden van Verhaal $V$ in zijn aanhef luiden: „Sjahadan tĕlah Batara Madjapahit [n.l. die getrouwd was met dat "kind" van den Radja Boekit Si-Goentang] soedah hilang [= dood], maka ananda Baginda jang toewa itoelah [dus - Raden Inoe Měrtawangsa] ganti Batara Madjapahit, tĕrlaloe sakali běsar kĕradjaän Baginda pada zaman itoe, sa loeroeh tanah $\mathrm{Djawa}$ itoe sĕmoewanja dalam hoekoem Baginda, dan sěgala radja-radja Noesa Tamara poen sa-těngah soedahtaloek kapada Baginda" 
$3^{\circ}$. blijkens alle gegevens van nu voortaan negatieven aard over "Mahasin, Hasin», en blijkens de nu juist positief wordende historische gegevens over een «Toemasik, Temasik» op dezelfde plek - de Zuidkust van het eiland van Singapore - , moet deze dood van Mahasin of Hasin een zeker aantal jaren hebben geduurd, alvorens zich weder Maleiers daar ter plaatse vestigden, en een stad stichtten met nieuwen naam: Toem asik, de "Zeestad». Volgens Verhaal III der Sadj. Mèl. deden zij dit van Bintan uit. Dit mag als een historisch-vaststaand feit worden aanvaard. En de naam alleen reeds geeft haast met stelligheid ook aan, dat deze naam-geving gebeurd is onder Javaanschen invloed, onder invloed toch van Toemapěl-Javanen, die na den val in 1292 van Toemapěl's hegemonie en den triomf van Madja. pahit in 1293, uitgezwermd kwamen naar of gebleven waren in Midden-Sumatra met omliggende Maleische eiland-groepen. Om duidelijk met jaartallen te spreken, zij het dan schattenderwijs: het verdwijnen van (Ma-)Hasin moet gebeurd wezen in ca. 1280, de stichting van de nieuwe stad Toemasik op ongeveer dezelfde plek in ca. 1300 A. D.

En hier dan komt nu ook de mogelijkheid op, dat Malaka geboren is.

Gewis niet in eens! Dat blijkt uit alle historische getuigenissen: M o ea $r$ heeft hierbij een gewichtig tusschenstadium vervuld. Het is de pleisterplaats geweest op weg naar Malaka.

Overzien we nu nog eens de diverse voorstellingen der stichting van Malaka, zooals ze hiervóór op blz. 24-28 uit de Port. bronnen van 1553 (Barros) - 1613 (Eredia) bijeen werden gesteld, en het overzicht dat op blz. 33-34 gegeven is uit Verhaal X-XI der in 1612 begonnen - of veeleer in $1614^{1}$ definitief aangevangen

1 Houdt men vast aan het jaartal (in volle woorden) 1021 Hidjra van de Inleiding, dan komt de daar gegeven dag en maand op Do. 12 Rabioelawal (Djimawal) $1021=$ Zo. (sic) 13 Mei 1612; houdt men echter vast aan den bijgevoegden jaarnaam „Dal”, dan zou men hebben - onder aanbrenging van de naastbij liggende correctie - : Do. 12 Rabioelawal Dal $1023=$ Di. (sic) 22 April 1614; maar houdt men vast aan de juistheid van den vermelden dagnaam "Chamis", dàn alleen krijgt men - alweder met naastbij liggende correctie èn in het jaar èn in diens naam - : Do. 12 Rabioelawal (Dje) $1022=$ Do. 2 Mei 1613. Nu is op zich zelf 12 Rabioelawal (= Moeloed) Dal reeds een opmerkelijke datum, door zijn bizondere gewijdheid ééns in de 8 jaar: de Garĕbëg-Moeloed Dal op Java, Moehamad's Geboorte-datum in een heilig jaar.

In deze blijkbare verwarring tusschen 3 opvolgende en mogelijke data, 
en afgesloten - Sadjarah Melajoe, welke de stichting van Malaka voorstelt als gevolg van een tweeden (en ditmaal, volgens haar, maar al te goed gelukten) aanval van een "Batara Madjapahit» op "Singafoera», dan komen we tot de conclusie dat de oudste, meest begaafde, en over het heele koloniaal archief in Lissabon beschikkende Port. geschiedschrijver, de beroemde JOÃO DF BARROS, het dichtst bij de waarheid moet zijn geweest toen hij die stichting stelde in ca. 1250 via de 4 etappen Oostjava-Singapoera-MoearMalaka; met dit voorbehoud: dat die geboorte van Malaka niet vóór 1275 kan plaats hebben gehad, veeleer pas in het begin der $14^{\mathrm{e}}$ eeuw zal gebeurd zijn, òmdat de Moear-periode van

hebben wij van elders gelukkig één vasten datum die hier tusschenin valt, dank zij Holl. gegevens: op 6 Juni 1613 werd de toenmalige hoofdstad van Djohor, Batoe S aw ar (verg. nader ons $I I^{\circ}$ Gedeelte), door de op $7 \mathrm{Mei}$ voor de koewala Djohor verschenen Atjehsche vloot veroverd en verwoest, de toenmalige Sultan (A laoedin Riajat Sjah III) gevangen genomen en mee naar Atjeh gevoerd, waar hij kort daarna overleed (wel 1614, of uiterlijk 1615), terwijl in ca. Sept. 1613 zijn ook gerangen genomen halve broer Radja Sabrang (alias: Radja Abdoellah, of R. Bongsoe, of ook Radja di Ilir) door den Sultan van Atjeh -- toenmaals Iskandar Moeda (reg. 1607-1636) - werd begenadigd, uitgehuwelijkt zelfs aan zijn eigen zuster, en met een Atjehsche vloot werd teruggebracht naar Djohor, om daar den leegen troon te bestijgen als Sultan Abdoellah Maäjat Sjah; welke toen, blijkens de duidelijke woorden der Inleiding van de Sadjarah Mĕl., aan zijnen Bĕndabara den "last" (titah) gaf: om de ${ }_{n}$ Hikajat... perri pĕristewa dan pĕratoeran sĕgala Radja-Radja Mĕlajoe dĕngan istiādatnja sakali" te schrij ven. Deze last, welke in den tekst dan ook begint met den sacramenteel-Vorstelijken vorm: Bahwa Beta minta $=$ (Voorwaar) "Ik verzoek", kan dus pas nà Sept. 1613 aan den auteur, den Bĕndahara [= Rijksbestierder $]$ van Djohor-Batoesawar, geheeten Toen Moehamad, alias (als kind) Toen Sri Lanang, verstrekt zijn.

Aan den anderen kant is het boven allen twijfel verheven, dat deze Hikajat vóor Sept. 1615 kant en klaar was. Want in die maand van dat jaar kwam de vloot van den met zijn schoonzoon in Djohor ontevreden Atjehschen Sultan opnieuw het uit zijn asch herrezene Batoe Sawar aanvallen en vernielen, waaruit Sultan Abdoellah Maäjat Sjah te voren was weggevlucht, en de wijk had genomen naar Bintan.

Wij houden dus als terminus a quo: Moeloed-dag van Hidjra $1021=\mathrm{Zo}$. 13 Mei 1612, waarin het denkbeeld van het schrijven der Hikajat het eerst geopperd werd door "Sa-orang Orang Běsar", zooals de Inleiding zegt; en als terminus ad quem: die noodlottige en definitieve tweede verwoesting door de Atjehers van Batoe Sawar in begin Sept. (of misschien eind Aug.) 1615.

En de dan daaruit weer als meest waarschijnlijke conclusie op te maken gevolgtrekking luidt: in het jaar Dal 1023 - hetwelk begon op Di. 11 Febr. 1614, en sloot met Vrij. 30 Jan. 1615 - is de Sadjarah Mĕlajoe definitief aangevangen en voleindigd, terwijl op 12 Rabioealawal Djimawal $1021=$ Zo. 13 Mei 1612 het eerste idee ontstond. 
zekeren duur moet zijn geweest; zoodat men aldus halfweg nadert tot de voorstelling van Couto uit 1602: dat die stichting pas in ca. 1350 geschied is. Daarnààst blijft dan de voorstelling door BRAZ I' AlbUQUerQUe uit 1557 van groot gewicht, die weliswaar over een andere kwestie eigenlijk het heeft (zonder het zelf te weten), n.l. het emporium-worden van de "stad» Malaka - zie verder hierachter sub $\mathbf{D}$-, maar één kostbaar gegeven heeft gered: dat de vorst van Java "Bata rata $\mathrm{murel}$ ", dùs de "Bhațāra Toemap̌̌l» = Kĕrtanagara, door zijn aanval en overwinning op den vorst van Palembang "Parimiçura» = Parameçwara, de oorzaak was geworden dat deze verdreven vorst met een deel Palembangers uitweek naar (het welbevolkte) Singapoera, en, na het daar te bont te hebben gemaakt, via de étappe-Moear, stichter was geworden van de stad Malaka. De geschiedschrijver Albuquerque, bastaardzoon en biograaf van zijn grooten vader Affonso, heeft hier dien naam Toemapěl ons overgeleverd, die in het 50 jaar later definitief geredigeerde Verhaal V - overigens tòch al zoo tendentieus - der Sadjarah Mělajoe tot "Madjapahit» is verhaspeld; en óók heeft Albuquerque hier voor ons gered de blijkbaar nog in ca. 1550 onder de Maleiers van Malaka en elders levende herinnering aan het antagonisme tusschen Palembang en Oost-Java in Toemapěl's bloeitijd.

Kan er nu nog iets naders gezegd over die halte te Moear? Gelukkig wèl, aan de hand van den aanhef in Verhaal XI der Sadjarah Měl., in verband met de jongste detailkaart van het Maleische Schiereiland, die van de Straits Branch R. A. S. in 6 bladen uit 1911 (Singapore-London, E. Stanford), ook elders in deze studie als standaard-kaart gebruikt.

Barros, zooals we zagen (blz. 27) noemt de plaats bovenstrooms aan de Moear, waar de eerst door dynastieke twisten uit (Oost-) Java en daarna opnieuw door den vorst van Siam uit Singapore verdreven "Paramisóra» = Parameçwara zich neerzette vóór hij Malaka ging stichten: Pago (spr. Pagoe). Albuquerque noemt geen plaatsnaam, doch spreekt alleen van de rivier "Moar". Couto in 1602 noemt géén Moear, maar een schijnbaar onherkenbaar Sencuder "dichtbij Oedjoeng Tanah», en gelegen op de "Kust van Malaka», als tusschenstadium; ${ }^{1}$ een naam, dien ik door een gelukkig toeval mocht thuisbrengen als blijkbaar

1 Verg. Ferrand, I, p. 444; en Couto's Decada IV, Parte 1, ed. 1778, p. 83: Sencuder, junto de Ujantana. 
te zijn het landschap Sekudai (Sěkoedai), met de S. Sekudai en de S. Malayu (nota bene!), welke een eindje beWesten het Johor Bharu van thans in de Selat Těberau vallen, zoodat deze naam mooi aansluit bij het Sðletar der Sadjarah Mělajoe dat nu zal volgen. ${ }^{1}$ Eredia zwijgt in dit verband. Maar de Sadj. Měl. noemt achtereenvolgens 3 plekken aan de Moear, waar de éérst naar Sëletar - d. i. naar den achterwal van het Singaporeeiland, in het midden ongeveer van de Sellat Těberau - en daarop naar de Moear gevluchte "Radja Iskandar» zich had opgehouden, vóór hij de "stad» Malaka ging stichten: $1^{\circ}$. Bijaw a k boesoek ( Rotte leguaan»), dadelijk daarop verlaten, wegens den hinderlijken overvloed van die gedierten ter plaatse; $2^{\circ}$. Kota boeroek ("Vervallen fort»), waar de Vorst eene kota had laten maken, die echter de eigenaardigheid had dat, wat men er overdag ook aan bouwde, 's nachts weer bouwvallig werd; $3^{\circ}$. eene plek, eenige dagen reizens dieper het binnenland in (mendarat), die gelezen kan worden Sěning Oedjoeng (Shellabear, p. 43), òf Sěnjang Oedjoeng (Leyden, 1821, p. 88 heeft "Sangang Ujung", maar op p. 191 beter: Senyang Ujung; Marre, 1896-1900, ${ }^{2}$ eerst in Verhaal XI: Sening-Oudjong, p. 61, later in Verhaal XVI: Senyang Oudjong, p. 127-128; Braddell, Journ. Ind. Arch. V, 1851, p. 320: Seniang Ujong). Op deze laatste plek stelde de Vorst een Mantri aan, en keerde terug

1 Zie deze 4 namen gekaarteerd op de „Schets der Sungai Johor", opgenomen aan het slot van ons $I I^{\circ}$ Gedeelte.

Men ziet hierbij tevens, hoe de stichting van Johor Bharu in 1855 een repristinatie was, een terugkeer tot een vroegere plek welke door de inlandsche traditie als gewijd werd beschouwd; een feit dat, voorzoover ik kon nagaan, nog nimmer is opgemerkt geworden van Europ. zijde. Aan de ten Westen van S. Sěkudai en S. Malayu loopende S. Pula i wonen sedert ca. 1825 restes van de oude Orang Kālang van Singapore; zie Logan's stukje "The Biduanda Kallang of the river Pulai in Johore" (Journ. Indian Archip., I, 1847, p. 299-302); waarin het Mal. bidoewanda aanduidt dat deze Kalang's weleer lijfknechten waren van de Radja's van Singapore-Toemasik.

De tekst van de Sadj. Mĕl. luidt in Verhaal X: "Sjahadan patah-lah pĕrang orang Singapoera: maka Radja Iskandar poen bĕrlěpas toeroen dari Sĕletar laloe ka-Moear" (Shell, 1898, p. 42). In Leyden's vertaling (1821, p. 87) ontbreekt deze plaatsnaam, misschien wel omdat hij er geen weg mee wist: „At last, however, Singhapura was subdued, and Raja Secander Shah, saving himself by flight, reached Moar." Devic $(1878$, p. 120) heeft: „le roi IskenderChah s'échappa, descendant de Salitar à la rivière Moara." Zelfs Marre (p. 60): "le roi s'échappa, descendant de Silitar jusqu'a Mouara"! Braddell (l. c. 1851), had al goed gehad: "Rajah Secunder fled to Sleitar and from thence to Moar."

'Zie hiervóór blz. 122, het slot der noot. 
naar het zeestrand (ka-těpi pantai); waarna dan de stichting van Malaka volgt aan het zeestrand bij eene «soengai Bërtam» inderdaad, blijkens Eredia in 1613, de toen nog gebruikelijke naam voor den bovenloop der soengai Malaka. ${ }^{1}$

Van de eerste twee plekken verzekert de Sadj. Mel., dat ze "tot heden" (datang sěkarang) zoo heeten; van de derde, dat daar "tot heden" een Mantri zetelt; trouwens, in het reeds aangehaalde Verhaal XVI blijkt dit een landschap te zijn, dat erfelijk apanage wordt van een Malakschen rijksgroote. Waar tegenwoordig "Bijawak boesoek» ligt, blijkt uit de kaart niet; het moet gezocht worden dicht bij zee, aan de Moear-rivier. Doch «Kota Burok» staat nog wel degelijk op de kaart van 1911: het ligt een eindje bovenstrooms der uitmonding van de S. Sendok, hiervóór in de noot op blz. 114-115 nader behandeld, aan den Oostoever der Muar, bij de groote lus of kromming die de rivier daar maakt, op een goedgekozen punt dus ter verdediging tegen vijanden die van zee kwamen, en met gemakkelijke vlucht hooger de rivier op. Waar de derde plaatsnaam thans nog kan liggen, blijkt weer niet uit de kaart; maar omdat die plek bovenstrooms van Kota Boeroek lag, en de S. Pagoh - waaraan het historische "Pago» van 1516-1520 heeft gelegen, dat in dit laatste jaar door de Portugeezen werd verwoest; zie blz. 27-28 hiervóór, en verg. ook Verhaal 34 der Sadjarah Mel. ${ }^{2}$ - een flink eind boven Kota Boeroek als linkerzijstroom in de Moear valt, zoo is er goede reden om Barros' "Pago, te vereenzelvigen met het "Senjang Oedjoeng» (of: Sening O.?) der Sadjarah Melajoe.

Hetzelfde, door de traditie gewijde, "Pago», waar de SingaporeMaleiers vóór hun stichting van Malaka het laatst aan de Moear gevestigd waren geweest, zou dan weer voor den in 1511 uit Malaka door de Portugeezen verdreven Sultan de plek zijn geworden om zich in 1516 opnieuw te nestelen, in de hoop, van dit Moear-gebied uit, zijn stad te kunnen heroveren op de vreemde indringers.

Er mag dus geconcludeerd: aan de Moear, vrij dicht bij den

1 Door deze uiteenzetting vervalt tevens de poging van C. O. Blagdex in zijne "Notes on Malay History" (Journ. Straits Branch, No. 53, 1909, p. 150-151) om in dit Sĕnjang (of Sĕning?) Oedjoeng der Sadj. Mal. het Sanghyang Hujung der Nāgarakĕrtāgama (Zang 14:2), en daardoor weer de Kaap Rachado bij het landschap Sungai Ujung (in Nĕgri Sĕmbilan) te herkennen.

2 In zijn ed. 1898 , p. 161 heeft Shellabear tot 3 maal toe de foutieve transcriptie: Pagah; doch in den $2^{\text {on }}$ druk, 1910, II, p. 225, goed: Pagoh. 
mond, maar toch een goed stuk hoogerop dan de monding der S. Sendok, heeft Kota Boeroek gewis een historische rol vervuld als tijdelijk verblijf van de uit (Ma-)Hasin = Singapore in ca. 1280 verdreven Maleiers; en is daarna hoogstwaarschijnlijk "Pago», of thans "Pagoh», doch vermoedelijk ten rechte $\mathrm{Pa}$ goeh of Pagoe, dat in Oudjav. beide (evenals Pag eh) beteekent "standvastig» - zie V. d. Tuuk, IV, 1912, p. 306-307; wat een mooie symbolische naam zou wezen - een tweede, misschien zelfs pas derde, pleisterplaats voor hen geweest, weer een flink eind verder bovenstrooms, alvorens zij er toe kwamen Malaka te gaan stichten.

De geboorte van Malaka mag daarom gesteld worden op haar vroegst tegen $1300 \mathrm{~A}$. D.

D. Het bestaan en de ondergang van Toemasik-Singapore in Madjapahit's bloeitijd (1300-1400 A. D.); en de terugslag op het ontluikend Malaka.

In ca. 1260 Çaka $=1338$ A. D. bestaat "Toemasik», blijkens de Pararaton, als een aanzienlijke staat, toen nog niet door Madjapahit onderworpen, en waaromtrent Patih Gadjah Mada in dat jaar zijn fameuze gelofte doet geen "palapa te willen eten", zoolang 10 Staten in 't Oosten en Westen van den Ind. Archipel, waaronder als laatste "Toemasik» wordt genoemd, nog niet onderdanig zullen zijn. Het is het buitenlandsch-politieke program, geuit door den in 1253 Ç. opgetreden Rijksbestierder van Madjapahit; zie reeds blz. 34-35 hiervóór. Het onder deze 10 ook met name genoemd worden van Gurun, Tañjungpura en Bali, voorts Seran en Dompo, impliceert, wegens het op blz. 140 gevondene: dat de eerste drie zeker, de laatste twee waarschijnlijk ook, zich tusschen ca. 1295 en 1325 A. D. weder onafhankelijk hadden weten te maken van den band der suzereiniteit aan Oost-Java, die blijkens Chau Ju-kua bij den aanvang van Toemapel's bloeitijdperk bestond. De geweldige gebeurtenissen op Java-zelf in 1292-93 zullen toch voor die "Buitenbezittingen» van Oost-Java het welkome sein zijn geweest om dien band weer te verbreken.

Maar in 1287 Çaka $=1365$ A. D. is, blijkens de Nāgarakertāgama (Zang 13-14), dat program van den in 't jaar tevoren overleden Gadjah Mada volledig tot werkelijkheid geworden. De gehééle Archipel, inbegrepen het Maleische Schiereiland, van 
Kẹda(h) aan de Westkust af, langs het landschap "Muwar», over «Tumasik» en «Lěngkasuka» en Oedjoeng Tanah ( ${ }^{\mathrm{H} u}$ jungmedini») in het Zuiden, tot aan (minstens) "Kalantěn» op de Oostkust, ${ }^{1}$ gehoorzaamt aan Vorst Hajam Woeroek te Madjapahit als Suzerein; verg. blz. 94-95 hiervóór. Slechts het nòg noordelijker Lakhon of Ligor ("Dharmmanagarī) op die Oostkust, is blijkens Zang 15:1, een met Oost-Java bevriende staat; evenals Siam, Kambodja, Tjampa, Annam ("Yawana»), Martaban ("Marutma»), een onzeker "Rājapura» (hoofdstad van Kalingga?), en een nog onopgelost "Singhanagarì , waarbij men zou kunnen denken aan Simphapura in Kalingga weleer, of zelfs aan $\mathrm{Simpa} l \mathrm{a}=$ Ceilon. ${ }^{2}$

En dan is er die raadselachtige inscriptie van Toemasik-zelf, de vernielde Singapore-oorkonde uit 13 . A. D., hiervóór uitvoerig besproken (blz. 35-67), en die ik, tevens in verband met Verhaal X der Sadjarah Mël., schatte op ca. 1360 ; terwijl Dr. Krom, afgaande op het schrifttype der fragmenten, haar wèl een Madjapahit-oorkonde acht, maar "wat vroeger dan 1360".

Daarnà, zeg dus in elk geval nà $1365 \mathrm{~A}$. D., verdwijnt «To emasik»; en "Singhapoera» komt op. Wanneer, waardoor, ... wij weten het niet! ${ }^{3}$ Het mag nog mooi heeten, dat, bij de inderdaad jammerlijke geschiedschrijving der Maleiers, de naam «Temāsik» ten minste nog gered werd in ca. 1612 door Verhaal I en III der Sadj. Měl., terwijl hierin elders steeds van "Singapoera» gesproken wordt. Doch geen enkele Port. bron der $16^{\mathrm{e}}$ en het begin der $17^{\mathrm{e}}$ eeuw, van Barros te Lissabon in 1552 tot den halfbloed Godinho de Eredia te Malaka in 1613, weet iets van een Tamasi (of hoe zij dit gespeld zouden kunnen hebben); zij weten alléén van een "Çimquapura», of "Cingapura», of "Sincapura», dat als emporium een gróóte beteekenis had gehad in de eeuw (of eeuwen) vóór de

1 Dit zou dan zijn tot ca. $6^{\circ} \mathrm{N} . \mathrm{Br}$. aan weerszijden der kust van het Schiereiland, óók thans nog het eigenlijk Maleische gedeelte; boven deze lijn KĕdahKëlantan begint het smallere Siameesche deel, als een langgerekte isthmus.

2 Zie de ed. Kern-Krom (1919), p. 51-52 en 262. Prof. Kern had er 't Mal. "Singapura" in gezien, wat strijdt met het "Tumasik" van Zang 14:2. Ook de door den staat Palembang in $1225 \mathrm{~A}$. D. beweerde suzereiniteit over Ceilon (zie hiervóór blz. 93 en 135), schijnt te pleiten voor een "bevriend" zijn met Java in 1365. Voor Simphapura zie Epigraphia Zeylanica, I, 1912, p. 124.

${ }^{3}$ In 1918 is een fragment-oorkonde op koper te Trawoelan (bij oud-Madjapahit) gevonden, door Dr. Krom geschat uit ca. 1315 Ç. = 1393 A. D., waarin o. a. vermeld wordt een "Pāduka Bhațāre [= Bhațära i] Singhapura". (Oudh. Versl. 1918, p. $170, \mathrm{v}^{\circ}$, r. $2-3$ ). Vrage: is dit het Maleische Singapura-Tumasik? 
stichting van Malaka - aldus Barros in zijn $\mathrm{II}^{\mathrm{e}}$ Decade van 1553, Lib. VI, cap. 1 -; dat wil dus zeggen, volgens Barros' eigen rekening van die stichting, in den tijd vóór 1250 A.D.; maar in verbeterd verband (wegens het eerst stad- en emporium-worden van Malaka van ca. 1400 A. D. af, zooals hieronder nader op goeden grond zal blijken): in de $14^{\mathrm{e}}$ eeuw A. D.

Hoe $\mathrm{T}$ oemasik in het midden dezer $14^{\mathrm{e}}$ eeuw, vóór zijn veroverd-worden door Madjapahit, er ongeveer uitzag, en welken anderen gevaarlijken vijand het toen ook had in Siam, blijkt op verrassende wijze uit een Chin. zeevaarder en auteur, die door wijlen W. W. Rockhill († 8 Dec. 1914) in T'oung. Pao XVI (1915) in het Part II zijner "Notes on the relations and trade of China with the Eastern Archipelago and the coast of the Indian Ocean during the $14^{\text {th }}$ century» toegankelijk is gemaakt. Het is WANG TA-YÜAN, die in 1349 zijn Tao $i$ chih lio ("Description of the Barbarians of the Isles») afsloot ${ }^{1}$ - het bezit een inleiding van een Tolmeester te Ch'üan-chou uit begin $1350-$, zelve koopman en zeevaarder in deze Indonesische en VoorIndische wateren sedert minstens 1330; zie aldaar p. 61-62, waar men op p. 62 onderaan de drukfouten « 1230 » en (in de noot) «1249» moet verbeteren. Bij zijn beschrijving nu van Hsien $=$ Siam, schrijft Wang Ta-yüan:

»The people [dus: de Siameezen] are much given to piracy; whenever there is an uprising in any other country, they at once embark in as many as an hundred junks with full cargoes of sago (as food) and start off and by the vigor of their attack they secure what they want. (Thus) in recent years they came with seventy odd junks and raided $\mathrm{Tan}-\mathrm{ma}-\mathrm{hsi}$ [hier volgen 3 Chin. typen] and attacked the city moat. (The town) resisted for a month, the place having closed its gates and defending itself, and they not daring to assault it. It happened just then that an Imperial envoy was passing by (Tan-ma-hsi), so the men of $\mathrm{Hsien}$ drew off and hid, after plundering Hsi-li [=?].

(Again) in the year ki-ch'ou of the period chih ch'eng (A. D. 1349) in the $5^{\text {th }}$ moon in summer they fell upon Lo-hu» [= Lopburi, aan de beneden-Menam]. (1. c. p. 100). ${ }^{2}$

1 Verg. reeds even hiervóór blz. 137, met noot 1. - Dit was een Chin. werk, dat Groeneveldt (naar pers. mededeeling in 1904) lange jaren, maar tevergeefs, getracht heeft te bekomen. Ma Huan noemt het in zijn Voorbericht.

"Dit Lo-hu is tevens het "Lo-hoh of Lo-kok" = Zuid-Siam, waarmede 
Hoewel deze laatste alinea slechts slaat op een onderlingSiameeschen strijd, is zij hier mede opgenomen, omdat zij $1^{\circ}$. één der twee data bevat, in Wang's werk voorkomend - het tweede is: "the kîng-wu year of the chilh-shun period (A. D. 1330) in the tenth moon, in winter» (p. 383), toen hij zeilende was bij Dondra (Dewandara), Ceilon's Zuidpunt ${ }^{1}-, 2^{\circ}$. omdat zij doet gevoelen hoe die vergeefsche ernstige aanval van Siam op de versterkte stad Toemasik in ca. $\mathbf{1 3 4 0}$ gesteld mag worden. Een verdere beschrijving van die stad Tan-ma-hsi geeft Wang helaas niet; maar wèl spreekt hij, na een beschrijving van o. a. Ligor òf Chaiya (Tan-ma-ling = Tāmbralingga), Pahang (P'êng-k'êng), Kělantan, Trěngganau (Ting-kia-lu), en diverse landsnamen die deels moeilijk thuis zijn te brengen, ${ }^{2}$

men Marco Polo's "Locac" (var. Lochac) uit 1292 tot nog toe heeft gelijk gesteld; terwijl ik hiervóór (blz. 142-145) aan de hand deed dit met Langka te vereenzelvigen.

1 Interessant is, dat op deze plek Wang Ta-yüan iets wat op een boom leek in het water zag drijven, en dan aan de matrozen vraagt: „Is this not a piece of pure lang-kan coral?" Hier blijkt een Chinees in 1330, die nog spreekt van Sèng-k a-la $=$ Ceilon (l.c. p. 375), óók te kennen lang-k an $=$ Ceiloneesch.

${ }^{2}$ In de eigen volgorde van Wang's tekst, door Rockhill l. c. p. $64-68$ als $n^{\text {os }}$ 1-99 gegeven (waarvan 29 nummers door hem niet vertaald zijn), slaan de volgende 45 nummers op onzen Ind. Archipel of schijnen daarop te slaan (met inbegrip van 't Maleische Schiereiland):

5. W u-chih-pa _- ? (tin-land; onvertaald); 6. Lung-yen hs ü_- Drakenspog"-, d. i. Ambergrijs-eiland = P. Bras (en niet "Pulo Rondo", zooals Rockhill p. 64 en 158 wil); 9 . Min-to-lang - ? (ebbenhout-land; onvertaald); 12 . Tanma-ling, zie boven, en hiervóór blz. 78-81; Rockhill vermoedt "Tembeling"; 14. Ma-li-lu $=$ Palele op Noord-Celebes?? (verg. de vertaling op p. 111-112); 15. Hsia-la - wu = (zegt Rockhill, p. 122 noot) wellicht Ki a-lo-hsi-alsdan (zooals we thans door Coedès' studie, p. 10-11, en 33-36 weten) Grahi, bij of gelijkwaardig met Chaiya (Baai van Bandon); 16. P'êng-k'êng = Pahang; 17. Ki-lan-tan = Kĕlantan; 18. Ting-kia-lu Trĕngganau; 19. Jung = Oedjoeng?; ergens op de Zuidkust van Malaya, misschien wel aan de Sëlat Těbĕrau, verg. de vertaling p. $128-129 ; 20$. Lo-wei = vroeger Shih-kia-lo shan ? (Rockhill p. 65 en 109 onderstelt aarzelend Ligor); 22. Tung-chungku-la = waarschijnlijk Chau Ju-kua's Tan-jung-wu-lo-alsdan Tandjoengpoera (Z.W. Borneo); 23. So-lo-ko=? (onvertaald; aan Soeloe hoeft niet gedacht, want dat volgt als $\mathrm{n}^{\circ} 38$ ); 25. Pa-tu-ma-Martaban? (hier opgenomen, daar Rockhill p. 255-256 aarzelt tusschen P. Tioman en Martaban); 26. Tan-mo = Tavoy ? (eveneens hier opgenomen, omdat Rockhill p. 254-255 denkt aan een eiland bij Java; verg. ook no. 68); 28. Pa-ch'ieh-na-chien=? (gewis niet "near Surabaya" zooals Rockhill p. 65 meent, terwijl hij op p. 250 den naam zelfs meent te kunnen geven als misschien "Pigirian" op Java); 29. San-fo-ch'i = Palembang (Rockhill heeft op p. 65 "Eastern Sumatra”; op p. 134 bij de vertaling „Jambi district”); 30. Hsiao-pên = ? (schijnt bij 
nader over het Lung-y.a mên of "Draken-tand kanaal», door Rockhill gewis terecht met "Singapore Strait" vereenzelvigd; in afwijking van Groeneveldt (Notes, 1876, p. 79-80; $2^{\mathrm{e}}$ ed. 1887, p. 203), welke er, zooals thans wel vast staat, ten onrechte de "Strait of Lingga» onder had verstaan.

Deze periode over Lung-y a mên begint en eindigt als volgt:

"The strait $(m \hat{n} n)$ is bordered by two hills of the Tanma-hsi barbarians [volgens 4 Chin. typen], which look like dragons' teeth (lung-y'a), between them there is a water-way:

The soil is poor and paddy fields few .... The people are addicted to piracy. In ancient times the chief in digging the ground found a bejewelled cap [volgt een verhaal over een ceremonie daarmede vroeger op Nieuwjaarsdag; men denkt vanzelf even aan de bij Tæloek Blanga in zee geworpen Bintan-makota, Sadj. Měl. II-III (Shell., p. 20 en 23), bij de vaart naar Těmasik]. Men and women live mixed up among the Chinese...

Neither fine products nor rare objects come from here, all they have is the product of their pillaging of the $\mathrm{Ch}$ 'uian-chou traders. When (Chinese) junks go to the Western Sea these

Kĕdah te liggen; onvertaald); $31 . \mathrm{P} \cdot \mathrm{o}-\mathrm{ni}=$ Broenai; $34 . \mathrm{Chao}-\mathrm{wa}=$ (Oost-) Java; 35 . Chung-ka-lo = Djanggala $=$ Soerabaja, en dan gelijk aan Chau Ju-kua's Jung-ya-lu (er staat op p. 66: Chung-kia-lo); 36. Tu-tu-an=? (Rockhill denkt aan een plek in Sumatra; onvertaald); 37 . Wên-tan = Banda; 38. $\mathrm{Su} \cdot \mathrm{lu}=$ Soeloe (verg. $\mathbf{n}^{\circ} .23$ ); 39. Lung-ya-hsi-kio $=$ m. i. Chau Jukua's Ling-ya-ssï-kia, en dan = Lĕngkasoeka (Rockhill p. 66 en 125 heeft: Lankawi islands, den tweeden keer met een vraagteeken; den eersten keer staat er: Lung.ya-hsi-chio); 40. Su-mên-pang = Soembawa? (helaas onvertaald, en dus niet nader te beoordeelen); 41. Ch'iu-chiang $=\mathrm{Ku}$-k ang (transeriptie-Groeneveldt, Notes p. 71 of 195$)=$ de "Oude Rivier" = Palembang (in de beschrijving hiervan spreekt Wang duidelijk van de P'eng-kia mên= Bangka-straat, p. 135, en komt de hoogst curieuze mededeeling voor: ${ }_{n} \mathrm{~A}$ l on $\mathrm{n}$ the roads there are many brick pagodas", ib.; 42. Lung-ya-po-t'i = m. i. de Langkawi-eilanden onder Kĕdah (welke Rockhill in Wang's no. 39 meende te herkennen, terwijl hij hier op p. 66 en 127-128 geen oplossing geeft; de

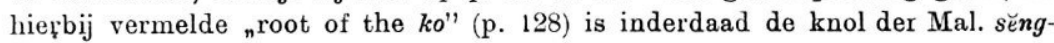
koewang, Pachyrhizus angulatus Rich., zie er noot 2 op p. 127); 44. Pan-tsu (wel corruptie van Mal. Pantjoer, zooals Rockhill p. 133 noot 1 terecht zegt) = Bintan (Rockhill aarzelt tusschen Batam en Bintan; maar "the hollow topped summit" van den centralen berg in de vertaling is duidelijk de zgn. Zadelberg of Piek van Bintan); 45. $\mathrm{P}^{\prime} \mathrm{u}-\mathrm{p}^{\prime} \mathrm{e} \mathrm{n}=$ Madoera (de aarzeling der gelijkstelling met Madoera bij Rockhill p. 66 en $251 \mathrm{kan} \mathrm{m}$. i. vervallen; men vraagt zich zelfs af, of dit niet evenzeer het nog raadselachtige $P^{\prime}$ ên-p'ên van I.tsing uit ca. 692 is, dat Takakusu in zijn ed. van 1896, p. XLIX, zegt te zijn $=$ P'u-p'ên); 46. Kia-li-ma-ta $=$ Karimata; 47. Wên-lao-ku = Moloekoe = Ternate $($ Rockhill p. 259 heeft het algemeene „Molucca Islands"); 
people let them pass unmolested, but when on the way back they have reached Carimon island [volgen 4 Chin. typen, waarvan de laatste 3 dezelfde zijn als " $n^{\circ} .21$. Keih-li-mên. Carimon» op de hieronder te behandelen Chin. kaart van vermoedelijk FEI HSIN uit ca. 1430] then the junk people get out their armour and padded screens [de nog in 1596 te Bantam welbekende rotan-matten als schansmatten op inlandsche schepen] against arrow fire to protect themselves, for, of a certainty; two or three hundred pirate junks will come out to attack them. Sometimes they [ = de Chin. jonken] may have good luck and a favouring wind and they may not catch up with them; if not, then the crews are all butchered and the merchandize made off with in short order.» (1. c. p. 129-132).

Hier hebben we een - waarschijnlijk wel wat zwartgallig overzicht van de gevaren die de Zuid-Chineesche schepen op hun thuisreis uit Voor-Indië opwachtten tusschen Karimoen en het nauw van Oedjoeng Tanah-Bintan, vanwege de Toemasik-zee-

48. Ku-li Ti-mên = Timor (het $\mathbb{K u - l i}$, elders $\mathrm{Ki}-\mathrm{li}$, vóór dezen Timornaam, blijft een raadsel; Goenoeng of Giri soms?; verg. Rockhill, p. 133 noot 1, en p. 257-259); 49. L ung-ya mên = „Draken-tand"-kanaal (óók = „Langka”straat?) = de Sělat Singapoera; verg. $\mathrm{n}^{\text {os }} 39$ en $42 ; 52$. Tung-h si-chu $=$ "OostWest-bamboe" = òf P. Aoer alléén, zooals Rockhill p. 124 heeft, òf P. Aoer + P. Tinggi, zooals ik hierna op blz. 164, noot 1 slot, nader aannemelijk zal maken (Rockhill p. 66 heeft nog ten onrechte "Anamba islands", dat de oude meening is); 53. Chi-shui-wan = "Razend-water-baai" $=\mathrm{m}$. i. de branding die altijd bij Diamantpunt of Oedjoeng Djamboe Ajĕr staat, en waar beWesten een ankerplaats is (Rockhill p. 66 en 144-145 zoekt dit punt ten onrechte in of bij de Suratte-passage); 54. Hua-mien = "Bloem-gezicht” = Batak (wel de kust bij Pedir); 55. Tan-yang = Tamijang, Tamiang; 56. Hs ü-wên-ta-la = Samoedra; 58 (op p. 66 staat onderaan foutief: 48 ). Kou -1 an $\mathrm{shan}=$ P. Bawal (alias P. Koempoel of Rendez-vous-eiland; 89 M. hoog) aan Borneo's Z.W.kust; en niet het lage, kleiner, en Zuidelijker P. Gĕlam (alias „Geram Island") zooạls Roekhill p. 66 en $26 \mathrm{~L}$ wil; en zeker niet „Billiton”, zooals Groeneveldt, Notes, p. $22,26,32$ en 78 (of $2^{\circ}$ ed. p. 148, 151, 157 en 201) wilde, waardoor tevens Ma-yi-tung = Balitueng, alias Billiton (en niet : Bangka), komt vast te staan, zooals Rockhill op p. 263 met noot 2 volkomen terecht zegt; naar ik vermoed is Chin. Kou-la n niets anders als Mal. Koelon, en de Chin. naam dus: „Westerbergeiland"; 59. T'ê-fan-li $=\mathrm{Hsiao} \mathrm{Shih}=$ ? (Rockhill p. 67 rraagt: in Sumatra?; onvertaald); 62. Nan-wu-li = Lamoeri, N. Atjeh; door Wang reeds geschilderd als nest van zeeroovers (verg. ook Rockhill's noot 3 op p. 148149 over Niu-tan-hsi = Tan-ma-hsi?); 68. Tung Tan-mo= "Oost" Tan-mo (verg. $\left.\mathrm{n}^{\circ} .26\right)=\mathrm{m}$. i. misschien Bima, o. a. wegens den rijstbouw, zie Rockhill, p. 255 (en zou dan soms Tan-mo = Soembawa-proper, West-Soembawa kunnen zijn??); 85. Pa-nan-pa-hsi = Bandjarmasin??; 88. Wannien-chiang $=$ ? (Rockhill p. 68 vraagt: „near Lingga island?”; onvertaald). 
roovers. Het massaal bijeenblijven door in konvooi te zeilen zal hier wel het gebruikelijk voorbehoedmiddel zijn geweest. Welke die Lung-ya $=$ "Draken-tanden» aan weerszijden der Straat (mên $=$ Mal. sělat) geweest moeten zijn, welke haar dien dreigenden Chin. naam hadden gegeven, zal in ons Ile Gedeelte, sub II, nader onderzocht worden bij oud-Singhapoera en de Sělat Singapoera.

Van een «Malaka» weet Wang Ta-yüan echter nog niet het minste.

We moeten nu een 80 jaar verder gaan, om op een gewichtig Chin. document, dat - zoover ik weet - nog niet speciaal de aandacht heeft getrokken in zake de stichting van Malaka en het bestaan van Singapore, aan te treffen: èn het emporium Malaka, èn den naam $\mathrm{Yiu-men}$ als een handelsplaats van beteekenis uit vroeger tijd op een der 5 Eilanden nabij de reede van Malaka, èn nog weer Tan-ma-hsi=Toemasik van daareven, als toen nog onder dezen naam bij de conservatieve Chineezen bekend. Het zol: echter verkeerd zijn hieruit op te maken, dat de naam Sing apoera niet reeds in ca. 1400 bij de Maleiers in zwang was gekomen, ook al kan niemand zulks tot nog toe strikt bewijzen.

Het is de Chin. kaart in 1887 door G. PHILLIPS publiek gemaakt en nader opgehelderd in het Journal China Branch R. A. S., New Series, XXI, bij Part II van zijn opstel "The seaports of India and Ceylon, described by Chinese voyagers of the $15^{\text {th }}$ century, together with an account of Chinese navigation from Sumatra to China» (p. 30-42), nadat hij bij Part I in den jaargang daarvóór (XX, 1886) reeds het Westelijk gedeelte van deze Chin. zeekaart .(van Oost-Afrika over Voor-Indië tot N.W. Sumatra) uitgegeven en behandeld had. Deze Oostelijke helft van de Chin. zeekaart, in 1887 gepubliceerd, begint bij Samoedra (Su-mên-ta-la) en eindigt met Ch'üan-chou (Marco Polo's Zaitoen van 1292), of eigenlijk bij Nanking.

Hoe oud was deze kaart? Phillips-zelve schatte haar als volgt: "I am inclined to think that these charts [die West- en Oosthelft zijn twee verschillende bladen] are older than the commencement of the fifteenth century» (1. c. XX, 1886, p. 210; en verg. er p. 214-215). Daarbij had men zich neergelegd, te gereeder, omdat Phillips ook dadelijk geweren had op de merkwaardige aansluiting bij den tekst van MA HUAN uit $1416-$ of, zooals men tegenwoordig, m. i. op zwakke gronden, liever 
zegt: uit ca. $1430^{1}$-, waaruit Groeneveldt zoo hoogst merkwaardige bizonderheden over den Ind. Archipel in zijne Notes had te voorschijn gebracht. Men schatte deze twee kaarten dus gewoonlijk uit ca. 1400 .

Maar in den laatsten tijd is men tot de wetenschap gekomen, dat deze kaarten met groote waarschijnlijkheid gemaakt zijn door FEI HsIN, den reisgenoot van Ma Hoean op één zeetocht (1413-15); dat wil zeggen weer: in het gevolg van den Eunuch Chêng Ho, die 7 maal was uitgezonden over zee door twee opvolgende Chin. keizers naar de landen der "Barbaren» (1405-ca. 1433). Diens $3^{\mathrm{e}}$ reis $(1413-15)$ zeker, en waarschijnlijk óók diens $5^{\mathrm{e}}-7^{\mathrm{e}}$ reis $(1421-22 ; 1424-25 ; 1430$ - ca. 33) heeft Fei Hsin medegemaakt als tolk-secretaris, tevens Mohammedaan van geloof, evenals Ma Hoean. Ik mag hierbij verwijzen naar mijn overzicht van beider geografisch-politieke mededeelingen, getrokken, aan de hand van Groeneveldt, uit hun twee boeken, de Ying-yai Shêng-lan van Ma Hoean uit 1416, en de Hsing-ch'a Shêng-lan van Fei Hsin uit 1436, in het artikel "Tochten (Oudste Ontdekkings-) tot 1497», Encycl. v. N.-I., 1e ed., IV (1905), p. 385390. Maar had Groeneveldt wèl in zijn Introduction van $1876^{2}$ uit Fei Hsin's werk gememoreerd, dat "within a time of more than 20 years, he was sent abroad with Chêng Ho four times, and from what he saw, he composed his book» (p. VIII), daar had hij - blijkbaar als niet ter zake dienend - nagelaten uit Fei Hsin óók te vertalen, dat hij "compiled maps», vóór hij zijn boek van 1436, na afloop van zijn 4 zeereizen met Chêng Ho, samenstelde. Zooals Rockhill, die dit meedeelt (1. c. p. 73), zelf al doet,

1 Men zie deze gronden bij Rockhill, l. c. p. 71-72, en zijn conclusie: „It seems safe to assign to the first publication of Ma Huan's work a date between 1425 and 1432". Het voornaamste argument is, dat Ma Huan den posthumen titel, in 1425 in zwang gekomen, gebruikt voor Keizer Yung-lo († 1423). Vrage: zijn zulks geen na-correcties van den uitgever Chang Shêng die in ca. 1436 (zie Rockhill p. 71) bij zijn Inleiding èn den naam van den auteur noemt als "Ma Huan”, èn het jaar 1416 als dat van eerste samenstelling? Verg. ook Groeneveldt (1876), p. VII (niet opgenomen in den herdruk).

2Deze heele "Introduction" van VIII pp., met den datum „Batavia, March 6th, $1876^{\prime \prime}$ op p. VI, is niet herdrukt in de $2^{\bullet}$ editie van 1887 (in Dr. Rost's ,Miscellaneous papers relating to Indo-China etc., $2^{\mathrm{d}}$ Series, Vol. I). De daar op p. 126 beginnende tekst - voorzien van het foutieve jaartal "1879" in plaats van ò 1876 ò 1880 ! - is die van p. 1 bij den $1^{\text {en }}$ druk; de zeer belangrijke "List of the works which have been consulted in making this compilation" (p. VII-X) ontbreekt er, en daarmede een goed deel van Groeneveldt's verantwoording tegenover Sinologen. Verg. noot 1 op blz. 119-120 hiervóór. 
mag men "surmise», dat de door Phillips in 1886 - 87 gepubliceerde 2 Chin. kaarten, werk zijn van Fei Hsin. Wat Rockhill hier bloot "vermoedt», lijkt mij een zéér groote waarschijnlijkheid. Behoudens verbetering van deskundige zijde, durf ik dan ook aannemen dat de 2 kaarten, door Phillips aangetroffen in het vrij moderne Chin. verzamelwerk Wu-pei-pi-shu, waar deze kaarten "are said to have been used by Chêng Ho» (l. c. XX, 1886, p. 210, 214-215) kartografisch werk zijn van FEI HSIN; en in dit geval waarschijnlijk geteekend na minstens 3 van zijn 4 reizen, zeg ca. $\mathbf{1 4 3 0}$.

Want nu vinden we op Kaart no. 2, aan de hand van Phillips in $1887,{ }^{1}$ en ons hier alleen beperkende tot de vaststaande of bijna vaststaande Chin. legenda op de West-, Zuid- en Oostkust van het Maleische Schiereiland, ${ }^{2}$ achtereenvolgens deze (door

${ }^{1}$ Het zou een schoone taak zijn voor een Sinoloog de 2 Chin. kaarten (de eerste 28 , de tweede $32 \mathrm{cM}$. hoog, bij niet minder dan resp. 1,40 en 2,30 M. lang) eens opnieuw en dan volledig to behandelen. Phillips heeft eigenlijk maar een greep gedaan in de verschillende bijschriften, en alleen bij zijn transcripties (1886, p. 221-224; 1887, p. 38-42) diegene opgenomen, welke hij min of meer kon thuisbrengen. In zijn $2^{\circ}$ artikel $(1887$, p. 31) erkent hij dit volmondig: ,There are numerous islands off the West coast of Sumatra [n.l. op Kaart $\left.n^{\circ} .2\right]$, but as I have not been able to identify them with certainty, I have not put them on my list. I have also not attempted to name the islands in the Straits of Singapore, and those lying off Cambodia point." - Bij den nu in den hoofdtekst volgende terechtbrenging der Chin. namen, mocht ik de voorlichting hebben van den heer B. Hoetink. Orer de poging van Blagden in 1909 , zie blz. 164, met noot 1 .

$3 \mathrm{Om}$ toch een denkbeeld te geven van den rijkdom aan gegevens voor Sumatra van deze Kaart, noteer ik hier (met behoud weer van de door Phillips aangebrachte volgeijfers):

A. Op Sumatra's Oostkust: 1. Samoedra (Su-mên-ta-la); 2. Pĕrlak-hoofd (Pa-lu-t'ou); 3. Kamperivier = de Tamiang-rivier (Kan-pei-kiang); 4. Haroe (A-lu); 22. Kampar-rivier (Kan-pa-kiang); 29. Palembang (Kiukiang = "Old river", d.i. de Chin. naam van "San-bo-tsai" nà 1397, volgens de Ming-annalen, Groen. 1876, p. 71 en 73, of 1887, p. 195 en 197; verg. echter al in 1349 Wang Ta-yüan's $\mathrm{n}^{\circ} 41$ op blz. 156 hiervóór, noot); 36. Lampoeng-rivier (Lan-pang-kiang). Hier wordt dus o. a. Kampe en Kampar zeer duidelijk onderscheiden; weder ligt Kampe benoorden Haroe.

B. Op Sumatra's Westkust: 5. Fantsoer (Pantjoer, Pan-tsuh) $=$ Baroes; 12. Tapanoeli-rivier, en Tapanoeli-hoogland (Lung-ya-kia-urh-kiang, en Lung-ya-kia-shan; Phillips, p. 38, heeft: „Indrapura river and mountain", doch de kaart, die een diepe baai met een eiland er vóór geeft, een eindje Z. van Baroes, wijst m. i. duidelijk naar de Baai van Sibolga, met P. Morsala er vóór, en de machtige Batang Toroe even ten Zuiden; curieus is weer, evenals bij $\mathrm{n}^{\prime \prime}$. 6 en 31a - zie onzen hoofdtekst blz. 161 en 163 - dat Lung-y a hier).

C. Eilanden beOosten Sumatra: 9. P. Bĕrhala (Tan-seu, d.i. „Alléén- 
Phillips genummerde) plekken, waarbij de met zekerheid herkende cursief werden gedrukt:

6. Langkawi[-eiland] (L ung-y-a-kia o-y i); 7. Këdah-rivier (Keih-ta-kiang); 8. Pinang-eiland (Pin-lang-seu); 11. P. Sĕmbilan, aan den mond der Perak-rivier (Kiu-chou $=\bullet$ Nine Islets»; verg. Groeneveldt's correctie op zijn Notes, T'oung Pao, VII, 1896, p. 116); 13. South Shoals, of Zuidzand, tegenover de Zuidelijkste monding der Kělang-rivier, de zgn. Kuala Jugra bij de van oudsher als baken dienende Parcelar Hill (Mien-huachien, d. i. "Katoen-bloem-rif", wel zoo geheeten naar de verkleuring van het water, op deze voor zeilschepen gevaarlijke zandbanken; bij Phillips, p. 38: South shoals); 14. Sĕlangoerbergland, dus het hooge bergland van ca. 1500-1800 M. dat de vlakte van Sělangoer scheidt van Pahang (Keih-na-ta-shan; Phillips, p. 38, heeft hier "Not identified»; de Chin. kaart geeft het echter, in verband met de ligging van 13 en 15, bijna ontwijfelbaar aan); 15. Kĕlang-rivier (K eih-ling-kiang; Phillips, p. 38, heeft "Kling river», wat hetzelfde bedoelt); 17. Kaap Rachado, alias Tanjung Tuan (Kia-wu-seu $=$ "False Five Islands», gewis omdat de naam $\mathrm{Wu}$-h sü, Wu-se u, d. i. (Echte) "Vijf eilanden", de beZ.O. van Malaka (zie no. 18) liggende eilandengroep aanduidt, zooals op blz. 165 nader zal blijken; de Chin. kaart geeft echter géén eiland, maar wèl een bergland aan zee te zien, het scherpsprekende landmerk dus van Cabo

eiland"; Phillips heeft terecht „Varela island (?)"; het is het „Ilha Polvoreira” verloopen vorm van Pulu Varela - P. Bĕrhala - uit den oudsten Port. tijd); 10. de Gebroeders, alias "Two Brothers", ten rechte P. Pandan en P. Salalı Nama, tegenover het landschap Batoe Bara (Shuang-seu, d.i. „Dubbeleiland"; terecht „The Brothers(?)" bij Phillips); 16. de Aroe-eilanden, of verhaspeld "Arroa Islands", en zelfs nog bij òns meestal „Aroa-eilanden", maar "Ilhas d'Aru" al in den Port. tijd, tusschen de monden der Panei-rivier en der Kĕlang-rivier aan den overkant, dus een prima-zeerooversnest weleer (K i-k u . seu, d.i. "Kippen-been-eilanden"; terecht „Aroe Island (?)" bij Phillips); 21. Karimoen (K eih-li-mên); 32. Bangka-bergeiland ( $\mathrm{P}$ 'eng-kia-shan; verg. hierróór blz. 74 , noot 2 , en reeds eerder in $1349 \mathrm{Wang}^{\prime} \mathrm{n}^{\circ} .41$ op blz. 156); 37 . "Sulphur Island" = P. Krakatau (Liu-huang-seu; rerg. p. 40 met p. 31 bij Phillips); 39. Blitoeng, Biliton (Ma-li-tung).

Daarna worden nog o. a. genoemd: Java, Karimoen (Djawa), en Karimata. Op Kaart $n^{\circ} 1$ (l. c. 1886, p. 221), vindt men nog op en bij N.W. Sumatra: 8. Lamoeri $=$ Groot.Atjeh (Nan-w u-li); 9. P. Wè (Mao-shan); 10. „Drakenspog-eiland" = P. Bras of Breuëh (Lung-yen-hsï); alsmede op de Westkust nog: 5. „Groote (en) Kleine Bloem-gezichten” (Ta-hsia-hua-mien), dus het Land der Getatoeëerde Batak's. De verklaring van 9 en 10 geeft Phillips in omgekeerde volgorde.

Dl. 77. 
Rachado, of de "Gespleten Kaap» (Port.), die van verre immers zich opdoet als een eiland; Phillips' tekst, p. 38, heeft "Fisher's islet (?)», d. i. de Eng. naam van P. Upih of Upeh, ten juiste Fisher Island, beN.IV. Malaka, halfweg tusschen de stad Malaka en Tanjung Kling); 18. [door een drukfout staat in Phillips' tekst, p. 38: 16.] Malaka (M u-a n-la-kia); 19. Senangen-berg (?) (Sia-ch'ien-shan; Phillips, p. 38, heeft: "Seginting», lees: Tanjung Segunting, aan den Z.oever der Batu Pahat-rivier; de «B. Senangen» ligt vlak daarbij, dicht aan zee, als zuidelijkste top van het complex van den G. Banang - «Groote Berg»alias Mount Formosa); 20. Pisang-eiland (Pi-sung-seu; het P. Pisang, waar nu een vuurtoren staat); 21. Karimoen (Keih-li$\mathrm{m}$ ên); 23. Blakang-Mati-eiland (Ch an g-y a o u-se u, d. i. "Longwaist-island»volgens BLAGDEN, zie hierna blz. 164 noot; Phillips, p. 39, heeft hier: "Singapore (?)», daar hij 24 niet herkend had); 24. Toemasik, Tĕmasik (T a n-ma-s e i h; Phillips, p. 39, had hier: "Not identified»); 25. Tekong-eiland? (Ta-na-ki-seu; Phillips heeft hier weer: "Not identified»; de Chin. kaart wijst m. i. duidelijk op P. Těkong, in den mond der koewala Djohor, met den van ouds als baken dienenden "G. Pengerang» of "Johor Hill» er vlak voor (201 M.), en den even hoogen G. B3elungkur N. daarvan ; 26. Si Kidjang-eiland alias St. John's Island? (P a-k i a oseu; Ph.: "Not identified»; het ligt op de kaart vlak tegenover 24); 27. Bintan-eiland, of Bintan-bergeiland (Ma-gan-shan, d. i. "Paarden-zadel-berg»; Phillips, p. 39, heeft "Ma-gan-seu [een drukfout voor shan]. Not identified». Maar ontwijfelbaar de zgn. "Groote Bintan», "Piek van Bintan», of »Zadelberg», 382 M., het centrale verkenningspunt in 't midden van 't eiland Bintan, vooral als men van het Noorden Pedra Branca (n०. 28) nadert; het ligt op de Chin. kaart vlakbij $n^{\circ} .28$, ook al makt deze de - óók bij Ptolemaeus (zie toch blz. 103) voorkomende grove kaarteeringsfout, om de lijn Singapore-Zuidchina als het verlengde voor te stellen van de lijn der Straat Malaka, in plaats van hier een scherpen hoek om de Noord te maken van ca. $80^{\circ}$ ); 28. Pedra Brancu(P e i - c hiao) $=$ "Witte Rots» (Port.; het befaamde eiland van kalkrots, met sinds 1850 de Horsburgh-vuurtoren, aan den O.-uitgang van Straat Singapore); 30. Pahang-rivier (P'engkeng-kiang); 31. P. Aoer, d. i. "Bamboe-eiland》 (Tung-sich'uh, d. i. "Oost-West-bamboe»; een naam wel daaraan toe te schrijven dat dit tot $550 \mathrm{M}$. hooge eiland twee toppen heeft, 
met een kloof tusschen beide, waarvan de Zuid-top het hoogst is; resp. 1521 en 1805 Eng. voet; terecht merkt Phillips, p. 39, in een bijschrift op, dat dit dus is het Tong-si-tiok van Fei Hsin, dat Groeneveldt in zijn Notes, 1876, p. 135 en $140-$ - of $2^{\text {e }}$ ed., 1887, p. 254 en 258-259 - ten onrechte dacht te zijn "the present island of Singapore»; 31a. "Draken-tandstraat» = Selat Singapoera (Lung-y a-mên ; Phillips, p. 39-40, aarzelt tusschen "the strait of Linga», "Singapore strait» en "Linga island»; inderdaad geeft de kaart deze "straat", mên, te zien als een "berg» of "bergeiland», shan, dat ten Zuiden van 28 ligt, halverwege 32 (P'eng-kia-s han = Bangka-bergeiland). Voor Lung-y a = Langka? zie op blz. 157 Wang's $n^{\circ} 49$; op blz. $161 \mathrm{n}^{\circ}$ 6: Lung-ya-kiao-y i = Langkawi; en $\mathrm{n}^{\circ} .12$ in de noot op blz. 160); 33. P. Tenggol van thans, recht Oost van Tanjung Dungun ( $4^{\circ} 47^{\prime}$ N.B.), maar bij de inlanders vroeger geheeten $P$. Berrhala - niet te verwarren met het P. Berhala op $3^{\circ} 17^{\prime}$, beZ.O. van den mond der Pahang-rivier! - , of ook in den Port. tijd : P. Capas do Mar - weer niet te verwarren met het P. Kapas sec, op $5^{\circ} 13^{\prime}$ beZ.Z.O. van den mond der Trĕngganau-rivier! - (T'ou-seu, d. i. "Schepel-eiland »; ligt op de Chin. kaart tusschen de monden der rivier-inhammen van $\mathrm{n}^{\text {os }} .30=$ Pahang, en $\mathrm{n}^{\circ}$. $34=$ Trĕnganau; verg. noot 2 op blz. 144 , èn op blz. 164; Phillips, p. 40, heeft hier: "Probably one of the Redang [door een drukfout staat er Kedang] islands», doch die Redang-eilanden liggen noordelijker, op ca. $5^{\circ} 40^{\prime}$, bij $n^{\circ} .35=$ Kělantan); 34. Trĕngganau (Ting-kia-hia-lu); 35. Këlantanrivier (Keih-lan-tan-kiang); 38. Senggora (Sun-ku-na).

Van al deze 25 nummers op of nabij het Maleische Schiereiland, had PHILLIPS reeds in 1887 zestien volkomen juist herkend - het klein verschil in opvatting van $\mathrm{n}^{\circ} .19$ mag geen naam hebben -, en had GERINI in 1905 het belangrijke Toemasik $\left(n^{0} .24\right)$ er reeds bij herkend. Van de thans hier gegeven zeven nieuwe herkenningen, zijn twee niet geheel zeker $\left(\mathrm{n}^{\circ \mathrm{s}} .25\right.$ en 26), komt één er weinig op aan ( $\left.\mathrm{n}^{\circ} .14\right)$, maar durf ik de vier andere $\left(\mathrm{n}^{\text {os }} .17,23,27\right.$ en 33) zeer belangrijk noemen, vooral de laatste drie in verband met de vaart door de "Draken-tandstraat» (Lung-ya-mên, no. 31a), die hierachter in ons $I I^{e}$ Gedeelte nader ter sprake zal komen, sub II.

Doch het allerbelangrijkste van PHILLIPS' korte toelichting bij deze Chin. kaart uit den tijd van Chêng Ho is hier nog niet 
overgenomen. Met opzet; er komt een afzonderlijke plaats aan toe. Zelfs C. O. BlaGden, die in 1909 deze Chin. kaart besproken heeft in zijne "Notes on Malay history" (Journal Straits Branch, $\mathrm{N}^{\circ}$. 53) heeft er geen woord over gezegd, hoewel met het Chineesch blijkbaar bekend. ${ }^{1}$

Bij het volgende mocht ik opnieuw de voorlichting hebben van den Sinolong B. Hoetink.

Terwijl hier en daar op de kaart-zelve in het vaarwater van Straat Malaka en het zuiden der Chineesche Zee (hier: tusschen Pahang en Bangka, $n^{\text {os }}$. 30 en 32) uitvoerige Chin. zeevaartophelderingen ${ }^{2}$ bijgeschreven staan, daar staat hier extra bij $n^{0} .18$ (dus: Muan-la-kia = Malaka) een aanteekening, die door Phillips vermoedelijk werd vertaald uit den tekst van de Wu-peipi-shu (zie reeds blz. 160); en wel als volgt:

"Formerly it [ $=\mathrm{Mu}$ a $\mathrm{n}-\mathrm{la}-\mathrm{k} \mathrm{i}$ a] was not called a kingdom, but

${ }^{1}$ In deze Notes (Sept. 1909, p. 139-162) neemt „IV. Further details from the Wu-pei-pi-shu charts" p. 153-160 in; waarbij Muan-la-kia op p. 157 aan de hand van Phillips kort wordt vermeld, maar diens alinea over "Y $\mathrm{Y} u$. mên" totaal verwaarloosd, misschien omdat Blagden dit niet op de kaartzelve terugvond.

Bị de herkenning van Tan-ma-seih = Toemasik, Temasik, op deze Chin. kaart reeds door Gerini (Journ. R. As Soc. 1905, p. 500-501) gedaan, sloot Blagden zich aan (l. c. p. 155). Het ,T. Segunting” op de kaart der Straits Branch van 1911 (aan den Z.mond der Batu Pahat-rivier), spelt Blagden in 1909: Tanjong Sagěnting (p. 157). Als nieuwe gegevens vindt men bij hem de vertaling van Phillips $\mathrm{n}^{\circ}$ 17: Ki a - w u-s e u met „False Five Islands” (p. 158), en diens $n^{\circ}$ 23: Chang-y a ou-seu met ,Long Waist Island" (p. 156, noot 1); bij dit laatste teekent hij aan: „Perhaps it is Pulau Panjang", waarmede hịj toch ook P. Blakang Mati kan bedoelen, dat omtrent 1840 wegens den langgerekten vorm wel eens zoo heette (verg. ons $1 I^{\circ}$ Gedeelte, sub II). -

$\mathrm{Bij}$ de op blz. 161-163 gegeven nieuwe herkenningen had ik veel baat van J. Horsburgh, The India Directory, $8^{\text {th }}$ ed, II (1864), en van de laatste uitgave van den Zeemansgids voor den O.-I. Archipel, $4^{\text {en }}$ druk, II (1916); men zie hun registers.

Slechts over één nummer kan m.i. nog gegronde twijfel blijven: zou de karakteristike Chin. naam Tung-si-ch'uh van no 31 , dus „Oost- (en) Westbamboe", niet veeleer slaan op de twee eilanden, $P$. Aoer (Oost) met hoogsten top van 1805 Eng. voet $+P$. Tinggi (West) met hoogsten top van 2046 E. v.? Die aldus als Oost- en West-wachters, beide met bamboe begroeid, lagen aan den ingang van de Straat Singapore, wanneer men kwam uit China, en welken ingang men zoo mooi uit de verte kon verkennen an den „Paardenzadel-berg" ( $\left.n^{\circ} 27\right)$ van Bintan, en dichterbij aan Pedra Branca $\left(n^{\circ} 28\right)$ ?

- Door Phillips vertaald l.c. p. 31-32, beginnende bij S u-mênta-la (no 1) en eindigend bij $\left.\mathrm{Chang-chow} \mathrm{(} \mathrm{n}^{\circ} 75\right)$. Een zeilaanwijzing in omgekeerde richting voegde hij bij (p. 32-33) uit de Tung-si-yang-k'ao (van 1618), waarin Touseu $\left(n^{\circ} 33\right)$ inderdaad het eiland is dat men van P. Condor bezeilt! 
as there were five islands on the coast [ook op de kaart geteekend; de welbekende IVu-hs ü = Five Islands der Ying-yai Shêng-lan vạ Ma Hoean uit 1416; zie Groeneveldt, Notes, 1876, p. 123 of 1887, p. 243, juncto Rockhill, 1915, 1. c. p. 114: Wu-hsü = Five Islets], it was called the Five Islands [dus wel op z'n Maleisch: Poelau Lima]. A large trading place by the name of [volgen 3 Chin. typen] Yiu-mên [-chên $=$ markt] was on one of these islands, which before Malacca was founded was a place of great trade. The country at that time was tributary to Siam.» (1. c., 1887, p. 38). [In het Hokkiansch van Emoi zou die naam luiden: Y u-bun (-tien); Hoetink.]

Deze verbazingwekkende onthulling, hierboven door mij cursief gedrukt, omtrent een groote Marktplaats op een van de 5 Eilanden ter reede $Z$. O. van Malaka - dat zijn dus met name, blijkens de kaarten: P. Běsar, het verreweg grootste; P. Undan, het verste in zee, nu met vuurtoren (Mal. oendan schijnt te beteekenen "langgerekt»); tusschen deze beide in: P. Dodol, P. Nangka; en W. van deze 2: P. A n y u t (Mal. anjoet, hanjoet, is "afgedreven, buiten den koers»), die nu nog op moderne Eng. zeekaarten te zamen Water Islands heeten, ${ }^{1}$ en $Z$. O. van de stad Malaka een flink eind uit den wal liggen - ouder dan de stad Malaka op den vasten wal als marktplaats, is ons hier gered in een toelichting bij een Chin. kaart uit Chêng Ho's tijd, vermoedelijk van niemand minder dan FEI HSIN, en uit ca. 1430. ${ }^{2}$

Ontsnapt als dit gewichtige gegeven tot nog toe is aan de opmerkzaamheid van allen, die zich interesseerden voor de middeleeuwsche geschiedenis van Malaka, stelt het mij in staat, ver-

1 Nog 3 kleine eilandjes liggen in een halven cirkel om de N.zijde van P. Běsar heen: P. Sěrimbun (W.), P. Burung (N.W.), en P. Lalang (O.). Van de 5 hierboven genoemde "Water $I^{s}$." is P. Anyut het kleinste, de 3 overige ongeveer even groot. Zie de Eng. Admiraliteits-Kaart no 795 (Cape Rachado to Singapore, April 1896; New ed. Aug. 1913), met daarop het detail-kaartje „Approaches to Malacca" (opname 1852, corr. tot 1903). P. Bĕsar heeft 3 toppen, waarvan de Noordelijkste 82, de Zuidelijkste $70 \mathrm{M}$.; het is ruim 10 maal zoo groot als P. Undan. P. Běsar, Dodol, Nangka, en Undan, liggen in deze volgorde ongeveer in een lijn N.-Z; P. Anyut ligt W. van de twee middelste.

2 Het verwonderlijke feit, dat deze belangrijke mededeeling niet voorkomt in Fei Hsin's tekst - die trouwens voor Malaka heel wat minder interessant is, dan die van Ma Huan; verg. Rockhill, l. c. 1915, p. 117-118 met p. 114117 - , doet de mogelijkheid aan de hand, dat het wel zal staan in den nog niet teruggevonden tekst van een derden reisgezel van Chêng Ho, n.l. de Hsi yang fankuo chih (,Description of foreign countries of the West”) van Kung Chên uit 1432 (òf 1434?); zie Rockhill, l. c. p. 71, 79-80. 
bonden met de hiervóór sub $\mathbf{A}$ tot $\mathbf{D}$ ontwikkelde gegevens van andere herkomst, te besluiten tot den volgenden aannemelijken ontwikkelings-gang van deze kort na 1400 A. D... tot emporiumopgebloeide Maleische stad:

$1^{\circ}$. De Pamalajoe, door Vorst Kerrtanagara van Toemapěl in 1275 A.D. uitgezonden, heeft ook het oude Māhasin, Hasin, op het eiland van Singapore verwoest, dezen vroegeren vijand van Java; het gevolg is tweeërlei geweest: een eerste golf van verdreven zee-Maleiers (wong asin later nog geheeten, zie blz. 73) heeft zich naar het Noordwesten gered, en aan den benedenloop van de Moear een of meer kolonies gesticht, waarvan thans nog de plaats Kota Boeroek (zie blz. 150-152) blijft getuigen; een ander deel der verdreven Maleiers is in ca. 1300 A. D. - in elk geval nà 1292; toen Marco Polo aan het eiland Singapore voorbij is gezeild - op de oude plek teruggekomen, en heeft er een nieuwe "zeestad» gesticht, Toemasik of T ґ masik, aldus waarschijnlijk genaamd in aansluiting bij den naam van het intusschen door Madjapahit overwonnen Toemapèl.

$2^{\circ}$. Van de Moear-rivier uit - die, naar allen schijn, reeds in den tijd van Mpoe Siṇọok (ca. 940 A. D.), dus tijdens het volle bestaan van Hasin, in zijn benedenloop te lijden heeft gehad van Oudjavaanschen aanval (zie blz. 113-114 met noot) - is verdere kolonisatie van Maleiers gegaan naar het Noordwesten, en heeft zich zoowat halverwege tusschen de Moear-monding en die van de Soengai Bertam (later S. Malaka), recht West van de koewala Kĕsang, eerst neergezet op de Poelau Lima (Chin. Wu-hsiu), en er een handelsplaats gesticht in ca. 1300 A. D., waarvan de eenige aannemelijke plek te zoeken is op het verreweg grootste dezer vijf eilanden, n.l. Poelau B ̌ sar, dat tevens het dichtst bij den wal ligt. Behalve handel, zal op deze groep het oude zeerooversbedrijf met voorliefde uitgeoefend zijn. Intusschen was de moederstad Toemasik krachtig opgebloeid, weerstond met succès in ca. 1340 een vloot-aanval van het (sedert 1205 Çaka $=$ 1283 A. D.) in opkomst zijnde Siam, maar werd vóór 1365 door Madjapahit overwonnen. De, op enkele fragmenten na, vernielde inscriptie aan den Z.O.mond weleer der Soengai Singapoera, moet het document zijn geweest van deze overwinning, geboekstaafd in Verhaal X der Sadjarah Mělajoe.

$3^{\circ}$. Deze overwinning van Madjapahit op Toemasik in ca. 1360 , of wat vroeger (zie blz. 67), moet een tweede golf van ver- 
huizende Maleiers gestuwd hebben in dezelfde richting, waarheen een driekwart eeuw daarvóór Mahasin-Maleiers gevlucht waren. Blijkens het gegeveven in de Pararaton, hiervóór (blz. 21-22) behandeld, bestond reeds in ca. 1250 Ç. $=1328$ A. D. de Oudjav. term Pam el Łkahan = een (ontwijfelbaar Maleisch) "Malaka-land». Zoolang we absoluut niet weten wat de heusche naam is geweest van de handelsplaats op (hoogstwaarschijnlijk) Poelau Běsar, die de Chin. kaart van ca. 1430 noemt $\mathrm{Yiu}-\mathrm{mên}$, is het niet mogelijk te zeggen of misschien op dat eiland ook die oudste plek heeft gelegen met den naam Malaka, dan wel op den vasten wal er achter, aan den mond der soengai Bertam. In dit laatste geval natuurlijk bij de strategische plek aldaar: de ca. 150 Eng. voet (zeg dus 45 M.) hooge heuvel aan den Z. mond daar, tusschen dien mond en de kleine Ajer (of soengai) Lèlèh, aan den voet van welken heuvel de astana met měsdjid der Maleiers, en het fort met hoofdkerk der Portugee\%en (sedert 1641 der Hollanders) later verrezen zijn; terwijl kampoeng Oepih (Upeh) ten $\mathrm{N}$. van dien mond de groote handelswijk werd voor de uit het N. W. aanvarende Voor-Indiërs (Hindoeïstische Klingaleezen en Moh. Guzeratten) alsmede de Chineezen, en de altijd veel kleiner gebleven kampoeng Ilir beZ. den mond der Ajĕr Lèlèh de nederzetting werd van een deel der uit het $Z$. O. aanvarende OostJavanen, vooral die uit Gresik, met het daarbij, vlak aan de kust, nog heden «P. Jawa» alias Red Island geheeten, kleine eilandje. ${ }^{1}$

De waarschijnlijkheid is er echter vóór, dat "Malaka» slechts bestaan heeft op den vasten wal, en juist in de oudere ontwikkeling der beschermend er voor gelegen Poelau Lima de gelegenheid heeft gehad tot eigen opkomst, zóó vlak aan het zeestrand.

1 Dit is het Ilha das Naos ("Schepen-eiland") uit den Port. en ook nog lateren Holl. tijd, omdat daar bezuiden de diepergaande schepen voor anker moesten gaan; hier waren dan ook scheepstimmerwerven in dien tijd; van dit eilandje uit is het gezicht op „De Stad Malacka” genomen bij Valentijn, V (1726), 1, fol. 309. Het nog meer Z.O. gelegen P. Panjang heette in den Port. tijd Ilha das Pedras, omdat men hier de steenen haalde voor bouwwerk in de stad. Het recht W. van kampoeng Oepil en Malacca Town gelegen P. Upeh, even ver uit den wal als $P$. Panjang, is thans quarantaine-station. Op de kaart uit 1613 van Eredia, ed. Janssen, 1882, p. 8 verso, wordt het (toenmalige) llha das Naos geheeten: Pulo Malaca, en door een landtong - blijkbaar schematisch - verbonden met den wal geteekend; op p. 11 verso vindt men het heele landschap Malaka, van den „Rio Panagin” (= Linggi-rivier) tot den „Rio Muar", en daarop ook het „I. grande" (= P. Bĕsar) met 5 eilandjes, W. van den mond der Kĕsang-rivier („Rio Cassam”). 
$f^{\circ}$. Deze oudste periode van Malaka-aan-wal, waarvan de tot heden bewijsbare terminus a quo aldus zou vallen in $1328 \mathrm{~A}$. D., moet afgesloten zijn nà 1365 - toen het nog niet gewichtig genoeg was, om vermeld te worden in Zang 14:2 der Nāgarakrětägama - ; het meest voor de hand liggend is het sterfjaar van den grooten Madjapahit-Vorst, Hajam Woeroek, daarvoor te nemen: 1311 Çaka $=1389$ A. D. Indien deze niet verslapt is in de uitoefening van het Rijksgezag gedurende de laatste helft van zijn regeering (begonnen 1350 A. D.), dan moet de Javaansche suzereiniteit over den Malaka-wal toch zeker bij zijn dood vervangen zijn door de opperhoogheid van Siam. Het onderdanig-zijn van Malaka aan Siam vóór 1409 wordt echter zóó uitsluitend geaccentueerd in alle Chin. berichten over Chêng Ho's gezantschaps-reizen naar de "Barbaren in 't Westen" ( $1^{\mathrm{e}}$ reis, $1405-07$; $2^{\circ}$ reis, 1408-1411), dat het veiliger is die "Siameesche» periode van het raadselachtige Yiu-mên op (hoogstwaarschijnlijk) Poelau Běsar en van Malaka-aan-wal wel degelijk vroeger aangevangen te schatten dan 1389. Zeg: in ca. 1370. Dit laatste jaartal zou ook mooi aansluiten èn bij het stichtingsjaar 1350 van Ayuthia als hoofdstad van het vereenigde Siam, èn bij de bewering van de "Palatine Law» van Siam (hiervóór blz. 22-23 behandeld, naar de gegevens van Gerini) als zoude «in A. D. 1360» onder de opperhoogheid van Ayuthia hebben gestaan: $1^{\circ}$. Oedjoeng Tanah, $2^{\circ}$. Malaka, $3^{\circ}$. Malajoe - wat hier òf Palembang òf Djambi zal moeten beteekenen ${ }^{1}$-, en $4^{\circ}$. Worawari, wat dan nu eindelijk in deze studie is thuis gebracht, als Ganggājoe van Verhaal I der Sadjarah Malajoe = L とngkasoeka. ${ }^{2}$ Het bovengenoemde jaartal ca. 1370 zou dan tevens een aannemelijke correctie bevatten van dit door de Siameesche bron ietwat gepraedateerde " 1360 ».

$5^{\circ}$. Even vast als deze vroegere onderdanigheid van Malaka en dan nu ook van "Yiu-mên» - aan Siam staat door de oudste Chin., alsmede Port. en Mal., gegevens, even ontwijfelbaar vast

1 Of mag hier worden gedacht aan het landschap Sěkoedai-Malajoe, op den achterwal beN. Singapore-eiland (zie blz. 150 hiervóór)??

2 C. O. Blagden, in Journal Straits Branch, No. 57 (Jan. 1511),.p. 189-190, verwijzend naar dit gegeren van Gerini, voegt toe: „The last name, Worawari, is a puzzle that no one has yet solved. Colonel Gerini offers various suggestions about it, one of them being that it stands for Muar, which seems hardly probable. Perhaps local knowledge may throw some new light upon it: the name may still exist in some modified form somewhere in the Peninsula." 
staat dat Malaka in $\mathbf{1 4 0 5}$ heul en hulp ging zoeken bij het Chineesche hof, in antwoord op een inviet van den in 1403 opgetreden, fantastisch-aangelegden, Keizer Yung-Lo (1403-† 1423), overgebracht door den eunuch Yin Ch'ing (zie de Ming-Annalen bij Groeneveldt, p. 129 of p. 248-249). En even ontwijfelbaar vast staat, dat de eunuch Chêng $\mathrm{Ho}$, bij zijn $2^{\mathrm{e}}$ gezantschaps-reis (zie boven), in het jaar 1409, volgens het getuigenis van Ma Hoean in 1416 (of ca. 1430??), naar Malaka kwam, en hier: * erected a stone [dus wel een steen met Chin. inscriptie] and raised the place to a city, after which the land was called the kingdom of Malacca. From this time the Siamese did not venture to molest it any more, and the chief of the country; having become king by the imperial favour, went with his wife to the court (of China) to present his thanks and to bring a tribute of products of his country. The Emperor sent him home again in a Chinese ship in order to take care of his land." (Groeneveldt, 1876 , p. 123 , en verg. 129 ; of 1887 , p. 243 , en verg. 249$){ }^{1}$

1 Rockhill, die een nieuwe vertaling heeft gegeven in T'oung Pao, XVI (1915) van den volledigen tekst van Ma Huan naar - zooals hij op p. 70 zegt: "the original edition... bearing no date or name or place of printing", zonder Inleiding door den uitgever Chang Shêng van ca. 1436 (zie hiervóór noot $1 \mathrm{op}$ blz. 159) - heeft een nog al afwijkende lezing hier, hoewel in de hoofdzaak volkomen analoog. Zie bij hem p. 114. In zijn noot woegt hij er aan toe o. a.: „Groeneveldt... has translated this chapter from the revised edition of the Ying yai shêng lan." Wanneer men echter in Rockhill's (zoogenaamde) ,original edition" zulken onzin ziet, als: "To the east and south it [n.l. Man-la-kia] confines on the sea, to the west and north is the coast which adjoins the mountains" - wat bij Groeneveldt goed luidt: "The country is bordered on the west by the ocean and on the east and the north by high mountains" -, of het onmogelijk beweren aantreft, dat Malaka jaarlijks aan Siam placht te betalen als tribuut "five thousand ounces of gold" (Rockhill), in plaats van "40 taels of gold" (Groeneveldt), dan mogen Sinologen nader uitmaken of Rockhill's tekst voor „original" mag worden asngezien, dan wel voor posterieur en verknoeid. Rockhill-zelf ziet zijn "printed copy" en "original edition", zijnde volgens hem „the earlier and shorter text" (p. 71), aan voor „probably of the very late Ming period" (p. 70); terwijl de andere tekst - mèt de Inleiding van Chang Shêng - in 1617 werd opgenomen in een Encyclopedie der Ming-periode (p. 71). Aangezien deze periode echter pas in 1643 eindigde, voelt men ook hier de zwakheid van Rockhill's opvatting.

Aan de vertaling van de $\mathrm{Hsi}$ yang chao kung tien lu („Record of the tributary nations of the West") door Huang Shêng-ts'èng uit 1520, is Rockhill, door zijn dood op 8 Dec. 1914, niet toegekomen; zie bij hem de inleidende p. 61 en $76-79$, l. c. De eerste 3 hoofdstukken - niet het eerste alléén, zooals Rockhill p. 79 meent - vertaalde W. F. Mayers in de China Review, dl. III-IV (1874-76), en wel 1. Chan-Ch'êng - Annam, 2. Chên-la - Kambodja, 
Hiermede is de wordingsgeschiedenis van het emporium Malaka afgeloopen.

De stad, die in 1413, bij de komst van Ma Hoean op Chêng Ho's derde gezantschaps-reis, reeds goed-Mohammedaansch heet wat "the king and the people» aanging, en inderdaad in 1414 een Kroonprins had met een Perz.-Arab. naamsuitgang (Mu-kansa-u-ti-r-sha; Groen. p. 130, of 250), doch pas wel in 1424, met het optreden van een nieuwen Vorst (ib.), een wezenlijk Moh. centrum werd, gaat nu, van 1409 af, haar groote geschiedenis beginnen als centrum van handel.

Doch éérder gewis niet. Daargelaten dan die "markt» (chên) van dat "Yiu-mên» (Mandarijnsch) of «Yu-bun» (Hokkiansch) op - met groote waarschijnlijkheid - Poelau Běsar. ${ }^{1}$

Moet er nu heusch nog nader gesproken worden over CORREA's alleen-staande, verbazing-wekkende bewering, dat Malaka gesticht zou zijn "meer dan zevenhonderd jaren" ("passante setecentos annos", Lendas, II, 1, p. 221 ; ed. 1860) vóór de Portugeezen naar Malaka waren gegaan, d. i. vóór 1509? Moet over dit geheel terloopsche zeggen van een slordig kroniekschrijver uit ca. 1561 (verg. Ferrand, I, p. 439, noot 1), hetwelk ons in diens slotbeschouwing als "la date... la seule possible» (II, p. 111) wordt aangeprezen, eigenlijk wel met eenigen ernst worden gedacht?

Neen! De man, die - om maar enkele sterke staaltjes te noemen - Vasco da Gama's ontdekkingsvloot laat uitloopen van Lissabon op 25 Maart 1497 (Lendas, I, p. 15) in plaats van 8 Juli, en laat terugkeeren op 18 Sept. 1499 (ib. p. 138) in plaats van 8 Sept., maar den duur van heen- en terugreis samen rekent op 32 maanden (ib. p. 144) in plaats van volgens zijn eigen cijfers nog niet 30 (lees ten rechte: 26 maanden precies); de en $3 . \mathrm{Kwa-wa}=$ Chao-wa $=$ Jara. De latere 20 hoofdstukken wachten nog op vertaling; al zij het dan in hoofdzaak compilatie uit Na Huan en Fei Hsin. Ook Mayers had door zijn dood ( $\dagger 24$ Maart 1878) deze vertaling laten steken.

1 Een zwakken steun voor het Chin. gegeven gaf Godinho de Eredia in 1613 , door te getuigen van een groot vierkant bouwwerk ,als een koninklijk paleis of fort" te Téloek Mas (,Tollot Mâs", tekst, ed. 1882, p. 15 ro), vrijwel recht Noord van P. Bĕsar op den vasten wal: in het A ppendix op ons II Gedeelte komt dit nader ter sprake. - Naar den klank, zou Chin.-Emoi'sch Yu-bun lijken op het Mal. Undan, zoodat men misschien mag denken aan een Mal. Pasar Undan $=$ Hokkian $\mathrm{Yu}$-bun-tien $=$ Mand. Yiu-mên-chên, als de naam van P. Undan (zie blz. 165), het verste en Zuidelijkste in zee.

Zie voorts nog over P. Bĕsar ons $I I^{\circ}$ Gedeelte, sub VII. 
man, die drie jaar lang één van de vier pennisten was geweest van den grooten Albuquerque (eind 1512- diens dood in Dec. 1515), maar desondanks dezen, na de inneming van Malaka (16 Aug. 1511, den dag na Assumptie-dag) en bevestiging van de nieuw-veroverde stad, op 1 Dec. 1511 (II, 268) vandaar naar Voor-Indië terug laat gaan in plaats van begin Jan. 1512, en hem in Jan. 1512 (ib., 270) te Cochin laat aankomen in plaats van in Febr.; ja, zoowaar, Albuquerque laat sterven op $27 \mathrm{Dec}$. 1515 (ib. 459) in plaats van 16 Dec.; de man, die de grondvesten van het Port. fort te Ternate in 1522 laat leggen op St. Jans-dag, oftewel, zegt hij, 25 Juli (ib., 715), lees: 24 Juni; de man, die zegt in 1504 eenige dingen met eigen oogen te Ormuz te hebben gezien, terwijl de Portugeezen er een fort bouwden (I, 815), terwijl hij zelf pas Sept. 1512 in Voor-Indië was aangekomen, inderdaad in Febr. 1515 Albuquerque gevolgd was naar Ormuz, en daar de verovering van de stad had bijgewoond; de man, die zegt op Corpus-Christi-dag van 1521 zelve te zijn medegegaan naar het heilig graf van St. Thomas te Meliapor met den nieuwen Gouv.-Gen. van Indië, D. Duarte de Menezes (II, 725-726), terwijl deze tocht in 1523 is gebeurd, en Menezes trouwens pas op 22 Jan. 1522 aan het bewind was gekomen; de man, die, alweder van zichzelven, zegt dat hij in Indië als jongen was aangekomen toen- dit 16 ("dezaseis») jaren (I, 2), was ontdekt - dus: Mei $1498+16=1514$-, en toch erkent dat «ik, Gaspar Correa, hem [Albuquerque] diende drie jaren als zijn pennist (escriuâo)» (ib. 134) - dus : Dec. 1515-3 = eind 1512 -; de man, die beweert dat Duarte Galvão de éérste officieele kroniekschrijver van Portugal was geweest (III, 6-7), welke bij zijn-vertrek naar Indië in 1515 als zoodanig werd opgevolgd in het moederland door Ruy de Pina, terwijl er inderdaad vóór Galvão al 2 waren geweest (Fernão Lopes, leeft nog in 1459; Gomes Eannes de Azurara, de zéér bekende, leeft nog in 1473; en toen pas Duarte Galvão, een van de weinige machtige vrienden van Albuquerque in patria, in de Roode Zee als gezant des Konings overleden in 1517); de man, die zijn grooten meester Albuquerque laat geboren worden vóór of in 1445 (II, 459) de eigen bastaardzoon Braz, èn Barros, hadden in hun werken van resp. 1557 en 1552, die beide aan Correa te Goa ter beschikking moeten hebben gestaan, gelijkelijk gezegd: $1452-$, terwijl thans gebleken is, dat Alb. geboren moet wezen tusschen 
1 April 1561 en 1562; de man, welke over dien bastaardzoon, die in 1500 geboren was, vertelt dat zijn vader hem verwekte als "jongman» (mancebo; II, 461), terwijl volgens Correa's eigen rekening Albuquerque toen al een eind over de vijftig moest zijn geweest; - de man, die tal van zulke slordigheden, dwaasheden, onnauwkeurigheden, enz., als een echte praatvaêr (zooals ik hem reeds in 1899 durfde noemen) ${ }^{1}$ in den herfst van zijn leven, gedurende $1560-63$, te Goa boekte in zijne Lendas da India ("Legenden», zeg: "Geschiedverhalen» van Indië), mag niet au séricux genomen worden wanneer hij, zóó maar eens eventjes, zonder iet het minste blijk van onderzoek of rechtvaardiging, met een los woord zegt: dat Malaka gesticht zou zijn in (1509, of 1511) - ruim 700 jaar $=$ ca. 800 A. D.

Welke vergissing of fout aan deze dwaasheid ten grondslag ligt, is moeilijk te vatten. De eenige oplossing van Correa's onzin zie ik voorshands in de onderstelling, dat hij het zeggen van Barros - in de hem te Goa natuurlijk ter hand staande $1^{\mathrm{e}}$ editie uit 1553 van diens II $^{\mathrm{e}}$ Decade —, dat Malaka gesticht zou zijn "iets meer dan twee honderd en vijftig jaar" (pouco mais de duzentos e cincoenta annos) ten tijde dat de Portugeezen in Indië kwamen [ $=1498]$, genoteerd heeft in zijn aanteekeningen als cijfers (ruim 200), en nu later, in 1560 of 1561, bij het schrijven van Deel II zijner "Lendas", die 2 heeft gelezen.... als 7 !

Vrede zij hiermee over CORREA's meer legendaire dan historische pen.

1 Bijdragen Kon. Inst. 6, VI (1899), p. 159, in 't A p pendix aldaar over de Port. koloniale litteratuur tot ca. 1600 (p. 145-173), en speciaal over Barbosa's Livro van 1516 (p. 173-196). Op p. 160, noot 1 trachtte ik daar aannemelijk te maken, dat de dood van den kroniekschrijver Castanheda op 23 Maart 1559 te Coimbra, wiens Livro I-VII van 1551-54 aldaar verschenen waren, de groote prikkel werd voor Correa's opstellen van zijne Lendas.

(SLOT'T VADAG'T). 


\section{INHOUD}

\section{(van het Ie Gedeelte).}

Herkenning door Coedès: Çrīvijaya - het antieke Palembang, p. 1-2. Onderstelling van Ferrand: Malāyur = het antieke Malaka, bestaande tusschen ca. 800 en 1400 A.D.,p. 2-5. - Bestrijding van Ferrand's onderstelling: Malāyur is een getamiliseerde vorm van Malajoe = oud-Djambi (met situatie-schets der tegenwoordige Kota Djambi op p. 14), en niets anders (behalve bij Marco Por.o, wiens "Malaiur" = Palembang is); dus géén antiek-Malaka, p. 5-20.

Oudste getuigenis voor den naam „Malaka” uit 1328 A. D. in de Pararaton, p. 21-22. - Oedjoeng Tanah, Malaka, Malajoe, en Worawari, in Siameesche bron van 1360 A.D.(?), p. 22-23. - Oudște Port. getuigenissen over den tijd van Malaka's stichting, p. 24-26. Desgelijks over 't voorafgegane Singapoera, p. 26-28. - De Sadjarah Mělajoe (ca. 1612 A. D.) over de stichting en ondergang van Singapoera, p. $29-35$.

De vernielde (Oudjav.) inscriptie van Singapore, p. 35-67. - De Sadjarah Mělajoe over Tèmāsik-Singapoera, over Ganggājoe (- Woera wari), en over de inscriptie te Tĕmāsik, p. 37-49. - Het vernielen in ca. 1839 van deze Singapore-inscriptie, p. 50-55. - Fragmenten daarvan nog te Calcutta, in 't Indian Museum (thans tijdelijk in 't Raffles Museum, Sinyapore), p. 55-59. Getuigenissen over en beschrijvingen van de inscriptie, p. 60-66. - Schatting van haar ouderdom: ca. 1360 A. D., als oorkonde van Vorst Hajam Woeroek van Madjapahit, p. 66-67.

A. Kan Singapore vór 900 A. D. hebben bestaan? (p. 67-72).

I-TsiNG's Mo-ho-sin (ca. 690 A. D.) Oudjar. Hasin, alias Mā-hasin, p. 68. Andere gegerens voor de mogelijkheid van Singapore's bestaan vóór 900 A. D., p. $69-72$.

B. Singapore-HAsis tussohen ca. 900 en 1200 A. D.

(p. 72-134).

„Hasin” gedocumenteerd door ERLANGGA's inscriptie van 1034 A. D., p. 73-75. - Onderscheid tusschen Hasin en Wocrawari, p. 75. - Nadere verklaring der Tanjore-inscriptie van 1030 A.D., p. 76-80. - Nienwe en afwijkende oplossingen daarbij: Vaḷaippandūṛu - Phanrang; Mevilimbañgam Dinding?; Māppappālam = Pahang??, of veeleer Penang; Māyiruḍingam Groot Ji-lot'ing Hasin, òf Jelutong; Ilañgāẹogam Lěngkasoeka - Woerawari Ganggajoe; p. $80-88$.

Dus ook: Langka niet Ceilon, maar - antiek-Djohor, p. 89-90. - Wurawari, met hoofdstad Lwarām, gedocumenteerd voor 1006 A. D. in ERLANGGa's inseriptie van den Pĕnanggoengan, nu te Calcutta, p. 90-92. - Gegevens over Lĕngkasoeka, p. 92-95. - Oedjoeng Galoeh, Galoeh, wari-Galoeh,p.96-97. 
Gegevens ter localiseering van het Lañkā van 't Rāmāyaṇa, p. 97-103. De beteekenis van het historische Langka voor Java's geschiedenis en Hindoekunst, p. 103-105.

De historische realiteit der Vorstenlandsche regalia (oepatjara) (1. Banjak d̦alang, 2. Ardåwalikå, 3. Gadjah, 4. Kidang, 5. Sawoeng galing, 6. Garoeḍa, 7. Memreng, 8. Sěnoek), p. 105-131. De Garoeḍa als symbool van den triomf op Langka door ErlangGa, p. 112-125. - Conclusie, p. 131-134.

C. Het bestaan van Singapore, en de vermoedelijke geboorte van Malaka tusschen ca. 1225 en 1292 A.D.

('T oemapěl's bloeitijd). (p. 134-152).

Gegevens uit Cнаш Ju-кuА, 1225 A. D., p. 134-139. - Geografisch-politieke grenslijn tusschen Oostjava's en Palembang's macht in dien tijd, p. 139-141. - Marco Polo rept in 1292 niet van een Hasin of Toemasik, doch misschien nog wel van Langka, p. 141-145. - Vermoedelijke verwoesting van HasinToemasik door de Pamalajoe, in ca. 1280 A. D., p. 145-147. - Mogelijke eerste stichting van Malaka als gevolg daarvan, met Moear als tusschenstation, goeddeels volgens de Sadjarah Mĕlajoe, p. 147-152.

D. Het bestaan en de ondergang van Toemasik-Singapore in Madjapahit's bloeitijd (1300-1400 A. D.); en de terugslag op het ontluikend Malaka. (p. 152-172).

Gegevens over Toemasik's bestaan in de $14^{\circ}$ eeuw A. D., p. 152-158. Gegevens op de Chin. kaart (door PHILlips bekend gemaakt) uit Fri Hsin's tijd, ca. 1430 A. D., p. 158-164. - De Wu-hsü = Poelau Lima (P. Běsar + 4 kleinerej nabij Malaka's Z.O. strand in ca. 1400, met de vroegere groote marktplaats Yiu-mên ( waarschijnlijk P. Běsar), p. 164-165. - Conclusies over Malaka's mogelijken opgroei tusschen ca. 1275 en 1400 A. D., p. $165-170$.

Besluit: Correa's gegeven over Malaka's antiek bestaan sinds ca. 800 A. D., geloofd door Frrrand, is fout, p. 170--172. 